FÁBIO LIMA DA CUNHA

O IMPOSTO DE RENDA E A JURIDICIZAÇÃO DA

CONTABILIDADE:

O CONCEITO DE RENDA NO DIREITO TRIBUTÁRIO E SUAS RELAÇÕES COM A CIÊNCIA CONTÁBIL

Dissertação de Mestrado em Direito sob a orientação do Professor Doutor Roberto Quiroga Mosquera

FACULDADE DE DIREITO DA

UNIVERSIDADE DE SÃO PAULO

SÃO PAULO - 2013 
FÁBIO LIMA DA CUNHA

\title{
O IMPOSTO DE RENDA E A JURIDICIZAÇÃO DA CONTABILIDADE: \\ O CONCEITO DE RENDA NO DIREITO TRIBUTÁRIO E SUAS RELAÇÕES COM A CIÊNCIA CONTÁBIL
}

\begin{abstract}
Dissertação apresentada como requisito para habilitação ao título de Mestre em Direito, sob a orientação do Prof. Dr. Roberto Quiroga Mosquera, na subárea de Direito Tributário, integrada ao Departamento de Direito Econômico, Financeiro e Tributário da Faculdade de Direito da Universidade de São Paulo.
\end{abstract}


Ficha Catalográfica

Cunha, Fábio Lima da

O Imposto de Renda e a Juridicização da Contabilidade: O Conceito de Renda no Direito Tributário e sua Relação com a Ciência Contábil / Fábio Lima da Cunha ; orientador : Roberto Quiroga Mosquera. São Paulo : [s.n.], 2013.

Mestrado - Departamento de Direito Econômico, Financeiro e Tributário da Faculdade de Direito da USP, 2013.

1. Direito Tributário - Imposto de Renda. 2 - Imposto de Renda - Direito Tributário. 3. IRPJ. 4. Imposto de Renda - Ciência Contábil. 5. Juridicização da Contabilidade. I. Título. II. Cunha, Fábio Lima da. III. Roberto Quiroga Mosquera. 
BANCA EXAMINADORA 
Dedico este trabalho a minha filha Maria Carolina, razão de todo meu esforço e da completa e positiva mudança de rumo e objetivos na minha vida.

A minha esposa Regina, pela história que construímos todos os dias, por todos os obstáculos que já ultrapassamos e por acompanhar, bem de perto, o meu crescimento e aprimoramento enquanto ser humano. Que este trabalho sirva como mínima retribuição e alento pelas constantes ausências e "efeitos colaterais" que esse projeto trouxe às nossas vidas.

Aos meus pais, Raimundo e Fátima, obrigado pelo exemplo de dignidade e incondicional suporte que me deram por toda a vida.

A minha irmã, Daniela, e minha linda sobrinha Giovanna. Sei que posso contar com vocês pelo resto de meus dias, em nome da velha (mas jamais ultrapassada) instituição chamada família (sem ela, qual o sentido de todos os nossos esforços?). 
Ao Professor Roberto Quiroga Mosquera por viabilizar uma grande realização e motivo de grande orgulho de minha vida: o dificílimo ingresso no curso de mestrado em direito da maior e mais prestigiada universidade do Brasil. Meu sincero agradecimento por acreditar, desde o primeiro encontro, no potencial deste estudo, bem como pela generosa orientação com que contribuiu para o resultado desta pesquisa. 
O imposto de renda, em seus mais variados aspectos e particularidades, temse mostrado um dos temas mais complexos e debatidos pela doutrina especializada e pelos tribunais ao redor do mundo. No Brasil, jurisdição em que o Sistema Tributário Nacional encontra-se ampla e rigidamente arquitetado pela Constituição Federal, o tema ganha especiais contornos, dada a necessidade de fiel compatibilidade entre a legislação infraconstitucional e os limites minuciosamente desenhados pelo constituinte. A presente pesquisa pretende entrar nessa seara para abordar o intrigante binômio aspecto material e base de cálculo do imposto de renda das pessoas jurídicas. No que tange ao aspecto material, investigaremos o grau de influência da rigidez do Sistema Constitucional Tributário sobre a composição dos elementos que caracterizam a renda constitucionalmente tributável. Nesse mister, será necessário discorrer sobre as teorias que propugnam pela ampla liberdade do legislador infraconstitucional para estabelecer o significado de renda (teoria legalista) até aquelas que apontam pouca (ou nenhuma) autorização para construção do conceito de renda no âmbito infraconstitucional, eis que isso seria matéria eminentemente constitucional. E assim se fará para que, posteriormente, viabilize-se o cotejamento entre a renda constitucionalmente tributável e o lucro contábil apurado de acordo com a legislação societária, eis que, tradicionalmente, é esse o ponto de partida para a apuração da base de cálculo do imposto de renda das pessoas jurídicas. Para tanto, será preciso analisar as funções e os usuários da contabilidade, identificando a atual perspectiva e os critérios que guiam a elaboração dos relatórios contábeis. Feito isso, tratar-seá de responder a seguinte indagação: poderia o legislador tributário brasileiro adotar o modelo de dependência total, isto é, adotar o lucro contábilsocietário como base de cálculo do imposto de renda das pessoas jurídicas sem nenhuma correção ou limitação no seu processo de determinação, como acontece em alguns países? Em última análise, analisar-se-á criticamente se o lucro contábil, juridicizado que foi pelo Direito Societário e Tributário, confirmaria ou infirmaria o aspecto material do indigitado tributo a teor do Texto Magno.

Palavras-chave: 1. Direito Tributário - Imposto de Renda. 2 - Imposto de Renda - Direito Tributário. 3. IRPJ. 4. Imposto de Renda - Ciência Contábil. 5. Juridicização da Contabilidade. 
The income tax, in its various aspects and particularities, can be considered as one of the most complex and discussed issues by specialized doctrine and courts around the world. In Brazil, a jurisdiction that the National Tax System is comprehensive and almost tightly provided by the Federal Constitution, the issue gains special contours, specially about the compatibility between ordinary legislation and the limits provided by the constituent. This study intends to going through in this matter in order to discuss the intriguing binomial taxable event (material aspect of taxable event) and taxable basis of corporate income tax. Regarding to the taxable event, this study will investigate the influence of the Constitutional Tax System on the composition of the elements that characterize the constitutionally taxable income. At this point, it will be necessary discuss the theories that advocate the wide freedom of ordinary legislature to establish the significance of income (legalistic theory) and those theories that advocate little (if any) authorization to construct the concept of income by ordinary legislature under the argument that this matter would be eminently constitutional. And it will be done in order to make possible the comparison between constitutionally taxable income and accounting income determined in accordance with Brazilian corporate legislation, behold, traditionally, it is the starting point for calculating the taxable basis for corporate income tax purposes. For that, we will need to analyze the functions and users of accounting, identifying the current perspective and criteria that guide the preparation of financial reports. After this, we will be able to answer the following question: could the Brazilian legislature adopt the tax total dependency model, i.e., the corporate accounting as the taxable basis for corporate income tax without any correction or limitation on your determination process, as happens in some jurisdictions? In essence, this study intends to perform critical analysis of if the accounting profit, which was provided for Corporate and Tax Law purposes, confirm (or not) the taxable event provided by Federal Constitution.

Keywords: 1. Tax Law - Income Tax. 2 - Income Tax - Tax Law. 3. Corporate Income Tax. 4. Income Tax - Accounting. 5. Accounting Law. 


\section{O Imposto de Renda e a Juridicização da Contabilidade:}

O Conceito de Renda no Direito Tributário e suas Relações com a Ciência Contábil

SUMÁRIO

ABREVIATURAS

INTRODUÇÃO.

PARTE I:

O IMPOSTO DE RENDA NA CONSTITUIÇÃO FEDERAL. DIRETRIZES A SEREM OBSERVADAS PELO LEGISLADOR INFRACONSTITUCIONAL. FUNDAMENTOS PARA POSTERIOR CONFRONTO COM O LUCRO CONTÁBIL.

1. COMPETÊNCIA TRIBUTÁRIA E REFERÊNCIAS SÍGNICAS...........

1.1. Sistema de Referência....................................................................... 9

1.2. A Rigidez do Sistema Constitucional Tributário Brasileiro.................... 10

1.3. A Discriminação de Competências por meio de Referências Sígnicas... 13

1.3.1. Teoria Legalista...................................................................... 14

1.3.2. Abertura Semântica e Conceitos e Tipos Constitucionais............. 17

1.3.2.1. Tipo e Pensamento Tipológico......................................... 17

1.3.2.2. Discriminação de Competências e Conceitos e Tipos...... 19

2. A CONSTRUÇÃO DO SIGNIFICADO DE RENDA................................ 24

2.1. Acepção de Base de Renda............................................................... 25

2.1.1. Acepções Comuns....................................................................... 27

2.1.2. Teorias Econômicas e Fiscais.................................................... 30

2.1.3. O Signo Renda no Contexto do Direito Tributário Brasileiro

Pré-Constitucional......................................................................... 32 
2.2. O Teste da Confirmação da Recepção, na Constituição Federal, da Acepção de Base do Signo Renda.

2.2.1. Os Critérios da Universalidade, Generalidade e

Progressividade.

\section{O PRINCÍPIO DA CAPACIDADE CONTRIBUTIVA: LIMITE PARA O EXERCÍCIO DA COMPETÊNCIA TRIBUTÁRIA..........................................}

3.1. Princípios Jurídicos

3.1.1. Advertência Preliminar: o Conseqüente Normativo dos Princípios Jurídicos

3.1.2. Princípios Constitucionais como Limitadores do Exercício da

Competência Tributária 43

3.2. Princípio da Capacidade Contributiva.

3.2.1. Breves Considerações sobre a Causa dos Impostos, os Valores Inspiradores e a Positivação do Princípio da Capacidade Contributiva na Constituição Brasileira.

3.2.2. O Estado Ideal de Coisas a ser Preservado pelo Princípio da Capacidade Contributiva: A Tributação do Patrimônio.

3.2.3. Breves Considerações sobre o Patrimônio.

3.2.4. A Interpretação Possível de Disponibilidade Econômica de Renda.

3.2.5. O Princípio da Realização da Renda enquanto aplicação do Princípio da Capacidade Contributiva 
PARTE II:

O IMPOSTO DE RENDA DAS PESSOAS JURÍDICAS NA

LEI ORDINÁRIA. A CONTABILIDADE COMO INSTRUMENTO PARA IDENTIFICAÇÃO DA BASE TRIBUTÁVEL. CONFRONTO COM A RENDA CONSTITUCIONALMENTE TRIBUTÁVEL.

5. A CONTABILIDADE E SUA JURIDICIZAÇÃO.

5.1. A Contabilidade

5.1.1. Breve Contextualização Histórica: da Necessidade de Controle à Padronização Internacional de Procedimentos Contábeis

5.1.2. Funções: Do Controle Patrimonial Dirigido ao Proprietário ao Interesse Comum pela Predição de Fluxos de Caixa Futuros (information approach).

5.1.2.1. Impactos do Information Approach na Elaboração de

Relatórios Contábeis. 75

5.1.3. O Lucro e sua Manipulação pela Ciência Contábil.

5.1.3.1. Breves Anotações sobre a Evolução das Diferentes

Perspectivas de Lucro em Teoria da Contabilidade.

5.1.3.2. Fluxos Físicos de Caixa e Necessidade de

Representação Gráfica de Lucro (o Lucro Contábil).

5.1.3.3. Demonstração do Resultado do Exercício e

Demonstração do Resultado Abrangente.

5.1.4. Compreensão Teórica da Contabilidade.

5.1.4.1. A Contabilidade enquanto Destruição e Reconstrução da Realidade.

5.1.4.2. A Falácia da Fiel Demonstração do Patrimônio (Na Acepção Jurídica).

5.1.4.3. A Primazia da Essência Econômica sobre a Forma Jurídica: Distanciamento entre Direito e Contabilidade.

5.2. A Juridicização da Contabilidade no Direito Societário.

5.2.1. A Disciplina das Demonstrações Contábeis no Bojo da Legislação Societária: Suas Funções. 
5.2.2.1. Breve Contextualização e Motivos da Reforma.......... 98

5.2.2.2. Âmbito de Aplicação.................................................. 99

5.3. A Juridicização da Contabilidade no Regime do Imposto de

Renda......

102

5.3.1. O Lucro Contábil como Ponto de Partida para Identificação da Base Tributável....................................................................... 102

5.3.2. Os Critérios Contábeis Previstos na Legislação Tributária............ 104

5.3.3. O Regime Tributário de Transição.............................................. 106

5.3.3.1. A Neutralidade Fiscal Enquanto Princípio.................. 109

5.3.3.2. Casuística: A Abrangência do Regime Tributário de Transição.

5.3.3.2.1. Base de Cálculo dos Juros sobre o Capital Próprio...................................................... 112

5.3.3.2.2. Isenção sobre Distribuição de Dividendos..

5.3.3.2.3. Mensuração do Ágio Baseando em Rentabilidade Futura....

5.3.4. O Princípio da Legalidade Tributária e os Métodos e Critérios

Contábeis Emanados de Autoridades Contábeis.

\section{CONFRONTO ENTRE RENDA CONSTITUCIONALMENTE TRIBUTÁVEL E LUCRO CONTÁBIL}

6.1. Função Comparativa da Base de Cálculo: O Aspecto Material

Constitucionalmente Pressuposto e o Instrumental Contábil.

6.2. Os Atos de Reconhecimento e de Mensuração pela Contabilidade e o

Teste da Confirmação do Aspecto Material do Imposto de Renda.

6.2.1. Princípio da Realização da Renda e Valor Justo (Reconhecimento e Mensuração Contábil)...

6.3. Casuística

6.3.1. Ajuste a Valor Presente.

6.3.2. Arrendamento Mercantil (Leasing).

6.3.3. Lucros de Coligadas e Controladas.

6.3.4. Ativos Biológicos. 
6.3.6. Reconhecimento de Ativo Intangível nos Contratos de Concessão.

6.3.7. Variação Cambial..................................................................... 150

6.3.8. Ganho em Compra Vantajosa..................................................... 156

6.3.9. Ganho na Variação de Percentual de Participação Societária........ 159

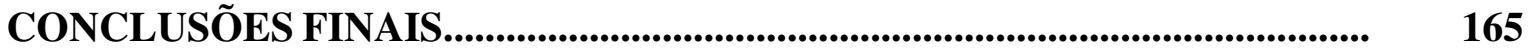

BIBLIOGRAFIA.......................................................................................................................... 170 


\section{ABREVIATURAS}

AVP - Ajuste a Valor Presente

BACEN - Banco Central do Brasil

CARF - Conselho Administrativo de Recursos Fiscais

CF/88 - Constituição da República Federativa do Brasil promulgada em 1988

CFC - Conselho Federal de Contabilidade

CPC - Comitê de Pronunciamentos Contábeis

CPC Básico - Pronunciamento Conceitual Básico, aprovado pela Resolução CFC n ${ }^{\circ}$ 1.374/11 e Deliberação CVM nº 675/11

CTN - Código Tributário Nacional, Lei n ${ }^{\circ}$ 5.172/66

CVM - Comissão de Valores Imobiliários

DRA - Demonstração do Resultado Abrangente

DRE - Demonstração do Resultado do Exercício

FASB - Financial Accounting Standard Board (entidade estadunidense que legisla sobre questões contábeis desde a década de 1970)

FCONT - Controle Fiscal Contábil de Transição, instituído pela Instrução Normativa RFB $n^{\circ}$ 949/09

IASB - International Accouting Standard Board (organismo internacional contábil independente com sede na Inglaterra)

IFRS - International Financial Reporting Standard (pronunciamentos contábeis emitidos pelo IABS)

IRPJ - Imposto de Renda das Pessoas Jurídicas

JCP - Juros sobre o Capital Próprio

LALUR - Livro de Apuração do Lucro Real

LSA - Lei das Sociedades Anônimas, Lei nº 6.404/76

MEP - Método de Equivalência Patrimonial

RE - Recurso Extraordinário

REsp - Recurso Especial

RFB - Receita Federal do Brasil

RIR/99 - Regulamento do Imposto de Renda, aprovado pelo Decreto ${ }^{\circ}$ 3.000/99

RTT - Regime Tributário de Transição, instituído pela Lei no 11.941/09 (conversão da Medida Provisória ${ }^{\circ}$ 449/08)

STF - Supremo Tribunal Federal

STJ - Superior Tribunal de Justiça

v.g. - verbi gratia (por exemplo) 


\section{INTRODUÇÃO}

Desde longa data, muito se tem discutido e afirmado, em sede doutrinária e jurisprudencial, sobre sérias e constantes divergências entre a tributação da renda ${ }^{1}$ desejada pelo constituinte originário e a estabelecida pela legislação ordinária que disciplina o Imposto de Renda no Brasil, notadamente no que se refere ao gravame devido pelas Pessoas Jurídicas ${ }^{2}$.

O debate não surgiu do nada e tem sua razão de ser. Por aqui, o Sistema Tributário, mais do que em qualquer outro sítio, é minuciosamente desenhado na $\mathrm{CF} / 88$, a ponto de Geraldo Ataliba - talvez com um certo exagero - afirmar que “(...) está o legislador (ordinário) sujeito a expressa e completa ordenação, a qual não lhe deixa liberdade jurídica de ação que ultrapasse os limites da simples discrição legislativa"3.

Nesse sentido, destaca-se no Texto Constitucional a rígida distribuição de competências tributárias entre os entes da Federação. Consequentemente, se, por um lado, a regra de competência atribui um poder à pessoa política, por outro, traz consigo uma limitação desse mesmo poder. Isso porque a competência “(...) tem efeito jurídico duplo, ou seja, positivo e negativo: do ponto de vista do nível de governo outorgado é uma afirmação constitucional de que este tem a competência para decretar determinado imposto e do ponto de vista dos demais governos da Federação é uma negação absoluta desta mesma competência."4

Em razão desses efeitos inerentes à competência tributária (positivo e negativo) é que surgiram sérios e competentes trabalhos doutrinários sobre a existência de um conceito constitucionalmente pressuposto de renda, o qual deveria ser observado pelo legislador ordinário, sob pena de comprometimento da distribuição de competência tributária previamente desenhada pelo legislador constitucional ${ }^{5}$.

\footnotetext{
${ }^{1}$ Em verdade, o constituinte empregou, no artigo 153, III, a expressão renda e proventos de qualquer natureza. Com o objetivo de facilitar a leitura do presente trabalho, muitas vezes iremos nos referir apenas ao signo renda, suprimindo a expressão proventos de qualquer natureza. Em momento oportuno, faremos a devida distinção.

${ }^{2}$ A confirmar nossa afirmação, Eduardo Domingos Bottalo assevera: "É fato notório existir grande distância, que sempre mais se acentua, entre o imposto sobre a renda delineado na Constituição Federal - com todos os princípios, critérios e diretrizes que ela consagra - e aquela que a legislação ordinária disciplina." (prefácio da obra de Roque Antonio Carrazza. Imposto sobre a Renda (perfil constitucional e temas específicos). 3 a. ed. São Paulo: Malheiros, 2009.)

${ }^{3}$ ATALIBA, Geraldo. Sistema Constitucional Tributário Brasileiro. São Paulo: Revista dos Tribunais, 1968. p. 30 .

${ }^{4}$ NOGUEIRA, Ruy Barbosa. Curso de Direito Tributário. 3. ed. São Paulo: Saraiva, 1971. p. 88.

${ }^{5}$ São exemplos de trabalhos doutrinários de grande valia os estudos de MOSQUERA, Roberto Quiroga. $O$ Conceito Constitucional de Renda e Proventos de Qualquer Natureza. São Paulo: Dialética, 1998;
} 
Em sede jurisprudencial, a confirmar a necessidade de estabelecimento de sentidos ao termos constitucionais, é sempre citada a célebre frase do Ministro do STF Luiz Gallotti: “como sustentei muitas vezes, ainda no Rio, se a lei pudesse chamar de compra o que não é compra, de importação o que não é importação, de exportação o que não é exportação, de renda o que não é renda, ruiria todo o sistema tributário inscrito na Constituição."6

Não podemos omitir o fato de que nem todas as autoridades vislumbram, no Direito Constitucional brasileiro, um sentido constitucional pressuposto de renda, tendo alguns revisitado a teoria legalista. Apoiados na suposta circunstância de que inexistiria um conceito ontológico, a renda seria tudo ou somente aquilo que a lei disser ser. Nada mais, nada menos! Assim, esvaziados de valor seriam os debates a respeito de um conceito constitucional. Neste ponto, o Ministro Nelson Jobim, do STF, chegou a afirmar que "o conceito de renda, para efeitos tributários, é o legal. (...) não há que se falar em um lucro real que não seja o decorrente da definição legal." ${ }^{7}$

A alimentar o debate, mencione-se a descrição da hipótese de incidência do Imposto de Renda empreendida pelo legislador complementar. Locuções como disponibilidade jurídica e econômica e acréscimos patrimoniais foram (e ainda são) objeto de análise de diversos tributaristas de peso desde a edição do controvertido artigo 43 do CTN. Pode-se afirmar que ainda hoje não existe consenso sobre o alcance e o sentido do indigitado dispositivo e, tampouco, sobre a própria função da lei complementar no desenho das competências tributárias.

É nesse contexto que se insere nossa pesquisa. Em última análise e sem meias palavras como subterfúgio para iludir o leitor, trata-se de mais uma contribuição para o (intrigante) estudo sobre a competência constitucional para instituição do Imposto de Renda. Porém, renovando nossa motivação para empreendermos o presente trabalho, Ricardo Mariz de Oliveira bem nos lembra: “O tema é inesgotável, e cada passo dado pela doutrina representa um degrau para um novo e posterior passo ascendente."

Com efeito, embora insistamos na investigação sobre a competência constitucional para instituição do Imposto de Renda, não é menos verdade que

GONÇALVES, José Artur Lima. Imposto sobre a Renda - Pressupostos Constitucionais. São Paulo: Malheiros, 2002; QUEIROZ, Luís César Souza de. Imposto sobre a renda: requisitos para uma tributação constitucional. Rio de Janeiro: Forense, 2003; CARRAZZA, Roque Antonio. Imposto sobre a Renda (perfil constitucional e temas específicos). 3a. ed. São Paulo: Malheiros, 2009.

${ }^{6}$ Voto do Min. Luiz Gallotti, citado pelo Min. Marco Aurélio, em voto no RE n. 150.764/PE, RTJ 147/1040.

${ }^{7} \mathrm{RE} \mathrm{n}{ }^{\circ}$ 201.456-6/MG.

${ }^{8}$ OLIVEIRA, Ricardo Mariz de. Fundamentos do Imposto de Renda. São Paulo: Quartier Latin, 2008. p. 171. 
pretendemos abordar seus problemas de forma a adotar determinados cortes metodológicos que diferenciarão nosso estudo dos trabalhos anteriormente elaborados sobre o tema (os quais serão de valiosa serventia no curso do presente estudo). Assim, o fulcro de nossa atenção será o binômio aspecto material/base de cálculo. Afinal de contas, conforme oportunamente adverte Victor Borges Polizelli, “(...) o Direito Tributário não pode se bastar em definir a base tributável sobre o conceito de renda tributável. São necessárias regras e convenções valorativas para viabilizar o cálculo da renda tributável." ${ }^{9}$ Nesse ponto, imprescindível será apurar se tais regras e convenções valorativas para viabilizar o cálculo da renda tributável confirmam, infirmam ou afirmam o verdadeiro critério material da hipótese tributária ${ }^{10}$.

Dentro desse objetivo, nossa intenção é, a partir da análise das normas que sustentam nosso Sistema Tributário Nacional, investigar a potencial existência de um sentido à renda constitucionalmente tributável e, se se confirmar sua existência, suas proximidades e dessemelhanças com o lucro apurado de acordo com os critérios e procedimentos contábeis admitidos pela lei societária brasileira. Nesse ponto, não é demais lembrar que é esse lucro societário o ponto de partida para a mensuração do quantum debeatur do IRPJ, conforme conhecida determinação constante da legislação afeta àquelas que se sujeitam, facultativa ou obrigatoriamente, à sistemática do Lucro Real ${ }^{11}$. Percebe-se, assim, que o Direito (Societário, Tributário, etc.) acolheu em seu sistema técnicas desenvolvidas ao longo dos tempos pelos estudiosos das ciências contábeis, pelo que se advoga pela juridicização da contabilidade.

Nossa proposta é apresentar o tema desde seus aspectos constitucionais, passando pelas determinações contidas na legislação complementar, até, enfim, analisar, de maneira crítica, a forma como o legislador ordinário estabeleceu a maneira pela qual o IRPJ será mensurado.

Vale anotar que o sistema de registros contábeis não está inserido no bojo da LSA por meras circunstâncias fortuitas. Sequer foi ele introduzido nesse diploma normativo exclusivamente para difundir, entre os empreendedores brasileiros, a prática de eficientes controles em prol de interesses estritamente gerenciais. Trata-se, em verdade, de

\footnotetext{
${ }^{9}$ POLIZELLI, Victor Borges. Balanço Comercial e Balanço Fiscal: Relações entre o Direito Contábil e o Direito Tributário e o Modelo Adotado pelo Brasil. in: Direito Tributário Atual ${ }^{\circ} 24$. Coords. BONILHA, Paulo Celso Bergstrom, COSTA, Alcides Jorge, SCHOUERI, Luís Eduardo, ZILVETTI, Fernando Aurélio. São Paulo: Dialética, 2010. p. 593.

${ }^{10}$ Sobre confirmar, infirmar ou afirmar o verdadeiro critério material da hipótese tributária, vide Paulo de Barros Carvalho (Curso de Direito Tributário. 17. ed. São Paulo: Saraiva, 2005. p. 334 e ss..)

${ }^{11}$ Artigo $6^{\circ}$ do Decreto-Lei $n^{\circ} 1.598 / 78$.
} 
um processo complexo, de relevantes efeitos jurídicos não apenas nas relações pertinentes à sociedade em si, mas também nas relações desta com terceiros, entendidos estes como os acionistas, empregados, administradores, clientes, fornecedores, governo - a comunidade, enfim, em que a empresa desenvolve atividade diária ${ }^{12}$.

Veja-se, desse modo, que a contabilidade extraída da LSA não é direcionada a atender propósitos específicos da relação fisco-contribuinte. Via de consequência, nada mais natural se surgirem divergências entre o resultado apurado de acordo com a lei societária e aquele desejado para fins tributários (entenda-se: pelo Direito Constitucional), justificando-se, portanto, que a lei tributária contemple ajustes e compensações, com o fito de chegar à mensuração da base tributável.

Destarte, tendo como norte a compreensão daquilo que seja a renda constitucionalmente tributável, bem assim os alicerces fundamentais que sustentam a elaboração dos relatórios contábeis, nosso objetivo último é esclarecer em que medida pode (ou deve) o legislador ordinário prescrever ajustes ao lucro líquido do exercício com o fim de alcançar a renda constitucionalmente tributável e, se for o caso, quais critérios devem ser observados no exercício dessa tarefa.

Acresça-se a isso tudo a recente edição das Leis $\mathrm{n}^{\circ}$ 11.638/07 e 11.941/09, as quais reformaram o capítulo das demonstrações financeiras da LSA, e as manifestações dos órgãos responsáveis pela uniformização de procedimentos contábeis, todas com o objetivo primordial de impulsionar o processo de convergência contábil internacional para, em última análise, facilitar o acesso das empresas brasileiras a capitais externos. Nesse específico particular, Ricardo Mariz de Oliveira, atento à reforma da LSA, observa que o novo padrão contábil “(...) passou a admitir uma visão econômica do patrimônio mais livre do que antes." ${ }^{13}$ Se antes a contabilidade societária era mais comprometida - porém, não limitada - em "traduzir" para sua linguagem o patrimônio da entidade sob a perspectiva dos direitos e obrigações na forma como regulado pelo direito, agora está-se diante de uma nova era, na qual as demonstrações contábeis são reflexo de aspectos mais condizentes com a tomada de decisões empresariais.

Com efeito, renova-se o já inesgotável tema da hipótese de incidência/base de cálculo do IRPJ, exigindo do pesquisador aferir em que medida o novo padrão contábil brasileiro se distanciou ou - pelo contrário - se aproximou da renda constitucionalmente

12 Cf. PASQUALIN FILHO, Roberto. Comentários à Lei das sociedades por ações: Lei 6.404/76. coordenação: Geraldo de Camargo Vidigal e Ives Gandra da Silva Martins. São Paulo: Ed. Resenha Universitária: Instituto dos Advogados de São Paulo, 1978. p. 130-131.

${ }^{13}$ OLIVEIRA, Ricardo Mariz de. Fundamentos do Imposto de Renda. São Paulo: Quartier Latin, 2008. p. 47. 
tributável. Nessa toada, é de se indagar se poderia o legislador tributário brasileiro adotar o modelo de dependência total, isto é, adotar o lucro contábil-societário como base de cálculo do IRPJ sem nenhuma correção ou limitação no seu processo de determinação, como acontece, v.g., na Alemanha e na Áustria ${ }^{14}$.

Eis, portanto, aqui presente $O$ Imposto de Renda e a Juridicização da Contabilidade: o Conceito de Renda no Direito Tributário e suas Relações com a Ciência Contábil, título de nossa dissertação de mestrado.

Para realização deste estudo, dividiremos nossa dissertação em dois grandes blocos, os quais chamaremos de Parte I e Parte II.

Na Parte I (O Imposto de Renda na Constituição Federal. Diretrizes a serem Observadas pelo Legislador Infraconstitucional. Fundamentos para Posterior Confronto com o Lucro Contábil.), discorreremos sobre os alicerces para construção da significação de renda constitucionalmente tributável. Delimitaremos a materialidade constitucionalmente possível para instituição desse imposto, desde a regra de competência inserta no artigo 153, III, da CF/88, até as demais limitações ao poder de tributar. Nessa ocasião, limitar-nos-emos à possível hipótese de incidência do gravame, para, ulteriormente, ingressarmos no intrigante tema da base de cálculo do IRPJ.

Firmados os fundamentos para a instituição do Imposto de Renda, na Parte II (O Imposto de Renda das Pessoas Jurídicas na Lei Ordinária. A Contabilidade como Instrumento para Identificação da Base Tributável. Confronto com a Renda Constitucionalmente Tributável) serão nossos desafios (i) abordar princípios, métodos e critérios que nutrem a elaboração das demonstrações financeiras nos moldes da LSA e, noutro momento, (ii) confrontar a possível hipótese de incidência do Imposto de Renda com o lucro contábil.

Melhor detalhando essas duas partes, no primeiro capítulo (Competência Tributária e Referências Sígnicas) da Parte I, nosso desafio será apontar as premissas para construção da significação dos signos constitucionais empregados para discriminação de competências tributárias. Abordamos algumas das celeumas que o tema provoca nos pesquisadores, como a questão de saber se tais signos encerram tipos ou conceitos.

Firmadas essas premissas, no segundo capítulo (A Construção do Significado de Renda) teremos como meta identificar as diferentes acepções do signo renda, tanto na

\footnotetext{
${ }^{14}$ Cf. POLIZELLI, Victor Borges. Balanço Comercial e Balanço Fiscal: Relações entre o Direito Contábil e o Direito Tributário e o Modelo Adotado pelo Brasil. in: Direito Tributário Atual $\mathrm{n}^{\circ} 24$. Coords. BONILHA, Paulo Celso Bergstrom, COSTA, Alcides Jorge, SCHOUERI, Luís Eduardo, ZILVETTI, Fernando Aurélio. São Paulo: Dialética, 2010. p. 593. p. 603.
} 
linguagem comum, como na linguagem técnico-econômica e, por fim, nos usos da linguagem do direito positivo e da metalinguagem da Ciência do Direito. Em última análise, será nosso desafio desvendar se essas diferentes acepções foram acolhidas pela regra de competência tributária conferida à União por meio do artigo 153, III, da CF/88.

Já no terceiro capítulo (O Princípio da Capacidade Contributiva: Limite Para o Exercício da Competência Tributária), discorreremos sobre em que medida os princípios constitucional-tributários servem para limitar ainda mais a regra de competência do artigo 153, III, da CF/88, com destaque para a capacidade contributiva.

No quarto capitulo (Conclusões da Parte I: Fundamentos para Posterior Confronto com o Lucro Contábil), encontrar-se-ão as principais conclusões da Parte I do presente trabalho e que são primordiais para posterior confronto com o lucro apurado de acordo com a lei societária.

Abrindo a Parte II, o quinto capítulo (A Contabilidade e sua Juridicização) tocará em aspectos relevantes da atual perspectiva da contabilidade e como ela foi juridicizada, em primeiro lugar, pelo direito societário e, por remissão, pelo regime legal do imposto de renda.

Por fim, no sexto (e último) capítulo (Confronto entre Renda Constitucionalmente Tributável e Lucro Contábil) - e fundamentados nas premissas contidas nos capítulos anteriores -, teremos a oportunidade de avaliar se o lucro apurado de acordo com a lei societária confirma, infirma ou afirma o aspecto material do imposto de renda. Dessa avaliação é que será possível responder à questão sobre se no Brasil é possível, ou não, adotar o modelo de dependência total entre as regras e métodos contábilsocietários e a base de cálculo do IRPJ.

Eis, portanto, aqui presentes nossos desafios, os quais serão enfrentados nas próximas linhas. 
PARTE I

O IMPOSTO DE RENDA NA CONSTITUIÇÃO FEDERAL. DIRETRIZES A SEREM OBSERVADAS PELO LEGISLADOR INFRACONSTITUCIONAL.

FUNDAMENTOS PARA POSTERIOR CONFRONTO COM O LUCRO CONTÁBIL. 


\section{COMPETÊNCIA TRIBUTÁRIA E REFERÊNCIAS SÍGNICAS}

\subsection{SISTEMA DE REFERÊNCIA}

Um enunciado qualquer, seja no âmbito do discurso científico ou não, deve ser projetado no contexto de um sistema de referência que lhe servirá como norte, sob pena de tal discurso causar confusões e desconfortos no receptor da mensagem ${ }^{15}$. É o que acontece - e aqui nos valemos do exemplo fornecido por Paulo de Barros Carvalho - quando, no bojo de uma conversa entre amigos, uma pergunta é formulada totalmente fora do contexto em que a conversa se dirigia até então ${ }^{16}$.

O mesmo se dá no campo da comunicação científica, só que de maneira ainda mais marcante, tendo em vista que a coerência e a harmonia entre o enunciado e seu sistema de referência é uma característica ainda mais esperada na linguagem científica.

Mutatis mutandis, podemos iniciar nossa pesquisa asseverando que o estudo do Imposto de Renda - aliás, assim como o de qualquer outra investigação jurídica - não pode ser concebido alheio às particularidades do contexto normativo em que está inserido, assim compreendido em seu todo sistêmico. A análise, portanto, não pode partir do Regulamento que disciplina o imposto ou mesmo da legislação ordinária que o instituiu. Neste particular, não há como ignorar que o Sistema Tributário Nacional é, com significativo grau de detalhamento, desenhado pela $\mathrm{CF} / 88$.

Para que a defesa de uma postura sobre o alcance e a abrangência do signo renda ganhe ares de rigor científico, torna-se imprescindível apontar o sistema de referência em que ele (signo renda) está instalado. E, nesse ponto, provavelmente chegaríamos a conclusões diversas se tivéssemos por base outro sistema. Isso implica dizer que a renda que tentaremos construir por ocasião deste estudo, certamente, será diversa da renda no ambiente da ciência econômica ou, ainda que jurídico, num contexto jurídico-

\footnotetext{
15 “Decididamente, a não-identificação do elo que prende o enunciado científico ao sistema de que faz parte aparecerá como sério transtorno no desenvolvimento do discurso, truncando o fluxo do pensamento e retirando, com isso, a potencialidade que a linguagem há de ter para cumprir sua proposta cognoscente." (CARVALHO, Paulo de Barros. Direito Tributário: Fundamentos Jurídicos de Incidência. 3. ed. São Paulo: Saraiva, 2004. p. 1)

${ }^{16}$ CARVALHO, Paulo de Barros. Direito Tributário: Fundamentos Jurídicos de Incidência. 3. ed. São Paulo: Saraiva, 2004. p. 1.
} 
tributário de características amplamente desconexas à realidade brasileira ${ }^{17}$. Nesse sentido, interessante é a análise do Direito Comparado levada a efeito por José Artur Lima Gonçalves em seu Imposto sobre a Renda-Pressupostos Constitucionais ${ }^{18}$.

Feita essa advertência preliminar, iniciaremos nossa empreitada a partir de algumas considerações sobre a rigidez do Sistema Constitucional Tributário Brasileiro, as quais, como dito alhures, serão fundamentais para edificarmos nossas futuras conclusões.

\subsection{A RIGIDEZ DO SISTEMA CONSTITUCIONAL TRIBUTÁRIO BRASILEIRO}

A partir do cotejo das Constituições dos diversos estados, a doutrina, dentre outras classificações ${ }^{19}$, vem adotando aquela que divide os Textos Supremos em analíticos e sintéticos ${ }^{20}$. Trata-se de classificação quanto à extensão da Constituição. Os últimos (Textos Sintéticos), por terem reduzido número de dispositivos, caracterizam-se por contemplarem normas de alto grau de abstração e conteúdo eminentemente axiológico (princípios jurídicos), o que conferiria ao legislador infraconstitucional a função concretizadora, por meio de imposição de regras.

Não é assim, porém, a $\mathrm{CF} / 88$, notadamente no que diz respeito ao Sistema Tributário. O constituinte dispensou um capítulo inteiro para disciplinar o Sistema Tributário Nacional, donde se infere que não se limitou a exibir regras de elevado cunho axiológico e baixo grau de concretização. De lá se extraem muito mais do que princípios norteadores do sistema de tributação ou, na consagrada terminologia de Victor Uckmar, princípios comuns de Direito Constitucional Tributário, encontráveis, de maneira análoga, em diversos ordenamentos ${ }^{21}$. Em confronto com o Direito Comparado, Geraldo Ataliba registrou, há tempos, a seguinte lição que, frise-se, permanece atualizada: "nosso sistema é

\footnotetext{
${ }^{17}$ Oportuna é a advertência de José Luiz Bulhões Pedreira: “A noção de renda que nos interessa não é a utilizada pela ciência econômica, nem a que teoricamente seja a mais perfeita para as finanças públicas; mas a que se ajusta ao sistema tributário nacional definido na Constituição vigente." (apud SACRAMENTO, Heber Gomes do. O mito do lucro real. In: MOSQUERA, Roberto Quiroga. LOPES, Alexsandro Broedel (coords.). Controvérsias Jurídico-Contábeis (aproximações e distanciamentos). São Paulo, Dialética, 2010. p. 173.)

${ }^{18}$ Vide capítulo 2 (Recurso ao Direito Comparado) de GONÇALVES, José Artur Lima. Imposto sobre a Renda - Pressupostos Constitucionais. São Paulo: Malheiros, 2002.

19 Sobre tais classificações, ver SILVA, José Afonso da. Curso de Direito Constitucional Positivo. São Paulo: Malheiros, 2001.p. 40 e seguintes.

${ }^{20}$ Cf. OLIVEIRA, Erival da Silva. Direito Constitucional. $3^{\mathrm{a}}$ ed. São Paulo: DPJ ed., 2004. p. 27.

${ }^{21}$ Cf. UCKMAR, Victor. Princípios Comuns de Direito Constitucional Tributário. Tradução de Marco Aurélio Greco. $2^{a}$ edição. São Paulo: Editora Malheiros, 1999. p. 17.
} 
sui generis, original e desconhece similares e réplicas; contrasta radicalmente com todos os demais;",22.

Por conta dessa extensa disciplina, que tolhe em determinado grau a liberdade do legislador infraconstitucional no mister de regular a legislação tributária, é que - em sede doutrinária - fala-se em rigidez do Sistema Tributário Nacional, rigidez a qual, como adverte Andrei Pitten Velloso, transcende a inerente às Constituições que não podem ser derrogadas pelo mesmo processo exigido para as leis ordinárias: "a rigidez do sistema constitucional-tributário decorreria da profundidade e extensão das vinculações que impõe ao legislador." 23

Sob essa perspectiva geral, interessa-nos discorrer sobre a rigidez quanto à distribuição de competências tributárias entre os entes políticos da Federação brasileira.

Nossa Carta estabeleceu quais e tais impostos e contribuições são de competência de um ou outro ente (vide artigos 149, 153, 155, 156, 195, todos da CF/88), deixando à União o poder de instituir os impostos residuais, mediante edição de lei complementar e "desde que sejam não-cumulativos e não tenham fato gerador ou base de cálculo próprios dos discriminados nesta Constituição" (artigo 154, I, da CF/88). Por conta dessa rígida disciplina, o Professor das Arcadas Paulo Ayres Barreto afirma categoricamente que: "A Constituição Federal de 88 pode ser definida como uma verdadeira Carta de competências." 24

Não há que se falar em competência tributária concorrente, mas exclusiva ${ }^{25}$, sob pena de fazer letra morta os dispositivos que atribuem competência aos entes políticos. Tal caráter é acentuado pela oportuna afirmação de Geraldo Ataliba, para quem: "a discriminação de rendas oferece um aspecto positivo - enquanto forma de outorga de competências - e outro negativo - enquanto inibe aos não contemplados pela outorga." ${ }^{26}$

Vê-se, pois, que o constituinte censurou a possibilidade de um ente da Federação exigir, dos contribuintes, tributo alheio a sua competência; ou, noutros termos, vedou a invasão de competência tributária.

\footnotetext{
22 ATALIBA, Geraldo. Sistema Constitucional Tributário Brasileiro. São Paulo: Revista dos Tribunais, 1968. p. 27.

${ }^{23}$ VELLOSO, Andrei Pitten. Conceitos e competências tributárias. São Paulo: Dialética, 2005. p. 146.

24 BARRETO, Paulo Ayres. Contribuições - Regime Jurídico, Destinação e Controle, São Paulo: Noeses, 2006. p. 30.

${ }^{25}$ Salvo as taxas e as contribuições de melhorias, tributos norteados pelo Princípio da Retributividade.

26 ATALIBA, Geraldo. Sistema Constitucional Tributário Brasileiro. São Paulo: Revista dos Tribunais, 1968. p. 35 .
} 
Quer-nos parecer que assim se fez, primordialmente, para proteger o modelo de Federação desejado pelo constituinte ${ }^{27}$. Afinal de contas, como diz Celso Cordeiro Machado, citado por Misabel Derzi, "no Brasil, a questão da discriminação da competência tributária é manifestação do próprio federalismo, por configurar partilha, descentralização do poder de instituir e regular tributos." 28

Queremos significar que a inobservância dos contornos constitucionais pertinentes à competência tributária representaria desvirtuamento do modelo de Federação desenhado pelo legislador constituinte. Tal modelo somente pode ser alterado por meio de emenda constitucional (e não unilateralmente por um ente político).

Explicamos melhor. O poder constituinte, desenhando o modelo federal brasileiro, atribuiu tais e quais encargos públicos a cada um dos entes políticos ${ }^{29}$; e, para poder concretizá-los, conferiu autonomia financeira a eles. Tal autonomia também foi detalhadamente arquitetada, quer por meio de competência tributária própria, quer pela técnica de repartição do produto de arrecadação de determinados impostos entre os entes. O constituinte pretendeu, dessa maneira, alcançar equilíbrio na relação encargos públicos/autonomia financeira, de forma a evitar que qualquer ente se sobreponha aos demais.

Esse minucioso desenho - que tem por fim tal equilíbrio - denominamos modelo (brasileiro) de Federação almejado pelo constituinte.

Destarte, impondo competência tributária exclusiva (e não concorrente), quis o constituinte evitar indesejável desequilíbrio na relação encargos públicos/autonomia financeira (reitere-se: evitando-se tal desequilíbrio, evita-se que qualquer ente se sobreponha aos demais). Caso contrário, estar-se-ia diante de uma deformação do modelo Federativo almejado pelo poder constituinte.

Nosso pensamento encontra eco na doutrina de José Artur Lima Gonçalves que, refletindo sobre a obediência às competências tributárias pelos entes federativos, assevera:

"Daí a importância do controle de eventuais distorções, alterações ou diminuições desses âmbitos de validade por meio de norma infraconstitucional,

\footnotetext{
${ }^{27}$ Não ignoramos que há quem dê relevo a outras circunstâncias para justificar a discriminação de competências tributárias na Constituição brasileira. O Professor Luís Eduardo Schoueri, por exemplo, salienta que o constituinte tentou impedir o excesso de tributação sobre uma mesma manifestação de riqueza. (Normas tributárias indutoras e intervenção econômica. Rio de Janeiro: Forense, 2005. p. 345)

${ }^{28}$ DERZI, Misabel de Abreu Machado. Direito Tributário, direito penal e tipo. São Paulo: Editora Revista dos Tribunais, 1988. p. 103.

${ }^{29}$ Sobre a competência dos entes, vide Título III (Da Organização do Estado) da CF/88.
} 
uma vez que, na sua ocorrência, afetado estaria o equilíbrio do princípio da Federação, tal como estabelecido na própria Constituição.”30

À guisa de conclusão, é importante reter neste momento que o modelo de Federação desenhado pelo constituinte originário somente pode ser alterado via emenda constitucional. Não poderá sê-lo de outra forma, como nos parece ser o caso de invasão de competência tributária por outro ente político. Daí a importância de, rigorosamente, estabelecerem-se limites das competências tributárias.

\subsection{A DISCRIMINAÇÃO DE COMPETÊNCIAS POR MEIO DE REFERÊNCIAS SÍGNICAS}

Como salientado acima, optou o legislador constituinte por atribuir, a cada ente político, competência específica para instituição de impostos e contribuições por meio da indicação de fatos-signos presuntivos de renda ou capital, na consagrada expressão de Alfredo Augusto Becker ${ }^{31}$. Como oportunamente salientado por Paulo Ayres Barreto, “dentre os vários parâmetros estabelecidos constitucionalmente para moldar a competência tributária, assumem especial relevo as referências sígnicas. ${ }^{\text {32. }}$.

Com efeito, o que pretendemos abordar neste tópico são os limites para atuação dos entes políticos no exercício dessa competência: se existentes tais limites e/ou em que medida eles são existentes.

A exemplo de Paulo Ayres Barreto ${ }^{33}$, iniciaremos nossas análises reconhecendo que existem, a priori, três possibilidades interpretativas, quais sejam:

(i) os diversos vocábulos constantes do Texto Constitucional devem ter sua significação construída a partir de exegese eminentemente constitucional;

(ii) os signos constitucionais devem ser entendidos como tipos, na acepção de ordens abertas, fluidas, sendo que os precisos contornos de seus significados dependeriam do que vierem a dispor as leis complementares;

\footnotetext{
${ }^{30}$ Prefácio da obra de PIZOLO, Reinaldo. Competência Tributária e Conceitos Constitucionais. São Paulo: Quartier Latin, 2006.

${ }^{31}$ BECKER, Alfredo Augusto. Teoria Geral do Direito Tributário. 2. ed. São Paulo: Saraiva, 1972. p. 453.

32 BARRETO, Paulo Ayres. Elisão Tributária: Limites Normativos. Tese. Livre-Docência. Universidade de São Paulo, 2008. p. 66.

${ }^{33}$ Cf. BARRETO, Paulo Ayres. Elisão Tributária: Limites Normativos. Tese. Livre-Docência. Universidade de São Paulo, 2008. ps. 66 e 67.
} 
(iii) os efetivos significados das referências sígnicas constitucionais dependerão do que vierem a dispor as leis ordinárias, que teriam papel de fixálos livremente.

Abordar essas três possibilidades será nosso desafio linhas adiante, começando pela última, a qual se denomina Teoria Legalista.

\subsubsection{TEORIA LEGALISTA}

Para os adeptos dessa posição, do Texto Constitucional não se extrai um conteúdo mínimo de significação dos signos lá expressados ou, nas palavras do Ministro do STF Nelson Jobim - ao se referir ao imposto de renda -, "o substantivo renda está, na Constituição, sem qualquer adjetivação." ${ }^{\text {’3 }}$ Não haveria que se falar em conceitos ontológicos ou essencialistas ligados aos signos constitucionais.

A partir dessa concepção, alega-se que é deferido elevado grau de liberdade ao legislador infraconstitucional para regular o aspecto material dos impostos e contribuições. Tais conceitos seriam, portanto, legais (e não constitucionais).

Todavia, pode-se dizer com segurança que tal ponto de vista é rejeitado pela grande maioria dos doutrinadores de peso e pela própria jurisprudência do $\mathrm{STF}^{35}$.

Pudera. Tal concepção não parece se adequar a duas premissas elementares, quais sejam:

(i) a discriminação de competências tem por função limitar a atuação dos entes tributantes; e

(ii) a interpretação constitucional não depende, pelo menos em tamanha magnitude, do direito infraconstitucional, uma vez que os signos constitucionais, em maior ou menor grau, possuem conteúdo semântico.

Queremos significar que o legislador constituinte não quis deixar ampla margem de atuação aos entes políticos (primeira premissa) e, mais do que meramente não querer, assim o fez pela indicação de signos constitucionais com conteúdo semântico (segunda premissa).

\footnotetext{
${ }^{34} \mathrm{RE} \mathrm{n}^{\mathrm{o}} 201.456-6 / \mathrm{MG}$.

35 No âmbito desse tribunal, merecem referência o RE 166.772-9/RS (que trata do conceito de folha de salários para fins da contribuição previdenciária) e, recentemente, o RE 390.840/MG (conceito de faturamento para efeitos da Lei $\mathrm{n}^{\circ}$.9.718/98).
} 
Em relação à primeira premissa, como tivemos a oportunidade de analisar alhures, a CF/88 fez uma clara opção pela rigidez na distribuição de competências tributárias e, caso fosse aceita a teoria legalista, todo o esforço do constituinte teria sido em vão ${ }^{36}$.

De fato, não faria o menor sentido a Constituição, por um lado, limitar o poder tributário dos entes da Federação por meio da discriminação de suas competências e, por outro, deixar a cada um dos titulares a prerrogativa de eleger os exatos contornos desse poder.

A Teoria Legalista representaria, assim, uma verdadeira preterição do Texto Magno; uma redução da Lei Maior em favor da conveniência legislativa de cada ente tributante.

Não se admite, dessa forma, que os contornos do poder tributário atribuídos pelo constituinte fiquem à mercê das definições levadas a efeito pelo próprio ente. Equivaleria isso a impor limitações ao poder de tributar e, ao mesmo tempo, conferir ampla liberdade para tal mister. Uma contradição em si mesma.

A esse respeito, são elucidativos os comentários de José Artur Lima Gonçalves, em estudo sobre o conceito constitucionalmente pressuposto de renda:

“(...) considerando que o texto constitucional serviu-se da técnica de referir-se ao critério material da regra-matriz de incidência tributária para o fim de proceder à repartição de competência tributária impositiva, o conceito de 'renda e proventos de qualquer natureza' foi utilizado para esse fim, sendo intuitivo que o respectivo âmbito não poderá ficar à disposição do legislador ordinário. Admitir o contrário implica conferir ao legislador infraconstitucional competência para bulir com o âmbito das próprias competências tributária impositivas constitucionalmente estabelecidas, o que é - para quem aceita o pressuposto básico do escalonamento hierárquico da ordem jurídica impossível. " 37

\footnotetext{
${ }^{36}$ Luís Eduardo Schoueri, criticando a posição adotada por Nelson Jobim, doutrina: "Vê-se que o Ministro levou seus pares a crer que haveria ampla liberdade para o legislador definir a hipótese tributária, desconsiderando que a discriminação constitucional de competências tributárias impõe que o legislador atue dentro dos parâmetros constitucionais. Merecem repulsa as teorias legalistas da renda." (SCHOUERI, Luís Eduardo. O mito do Lucro Real na Passagem da Disponibilidade Jurídica para a Disponibilidade Econômica. In: MOSQUERA, Roberto Quiroga. LOPES, Alexsandro Broedel (coords.). Controvérsias Jurídico-Contábeis (aproximações e distanciamentos). São Paulo, Dialética, 2010. p. 245.)

${ }^{37}$ GONÇALVES, José Artur Lima. Imposto sobre a Renda - Pressupostos Constitucionais. São Paulo: Malheiros, 2002. p. 170.
} 
Já no que tange à segunda premissa, não se pode negar que, a despeito da existência de vícios de linguagem (vaguidade, ambiguidade semântica, etc.), os signos constitucionais possuem, ainda que em diferentes graus, conteúdo semântico. Não são, portanto, completamente esvaziados de significação, mera porção de tinta jogada aleatoriamente numa base de papel, como bem reconheceu Paulo Ayres Barreto:

"Não é usual a preocupação do legislador constituinte em estabelecer, claramente, conceitos no plano constitucional. As referências terminológicas surgem como se unívocas fossem suas significações. Se, de um lado, essa univocidade não existe, é necessário reconhecer, de outro, que tais referências delimitam as possibilidades interpretativas." ${ }^{38}$

Isso implica dizer que não há total liberdade para o legislador infraconstitucional construir o significado dos signos constitucionais, sob pena de mutilar o Princípio da Supremacia Constitucional e desqualificar nossa Constituição como rígida, passando a ser daquelas flexíveis.

Nesse sentido, Andrei Pitten Velloso opina:

“(...) os signos lingüísticos, repisa-se, possuem significados conotativo e denotativo determináveis, conquanto em certas hipóteses a determinação somente se possa ocorrer de forma relativa. Tal ilação é meramente analítica, visto que, caso contrário, signos lingüísticos não seriam, mas meros ruídos ou amontoados de letras, carentes de significação. A Constituição, no entanto, não traz em seu bojo amontoados de sinais gráficos afásicos. Isso pode ser afirmado de caráter categórico." 39

Portanto, o argumento de que a Constituição não adjetivou o substantivo renda (como quis o Ministro Nelson Jobim) revela-se por demais simplório, insuscetível de prevalecer em nosso Sistema Constitucional. Quis o eminente Ministro deixar a entender que o vocábulo renda não dispõe de nenhum conteúdo semântico, remanescendo ao legislador infraconstitucional alto grau de liberdade (ou melhor, arbitrariedade) para discipliná-lo. Assim não se pode conceber, uma vez que o signo renda possui conteúdo semântico a ser desenvolvido pelo intérprete, para efeito de identificação dos limites a que deve se submeter o titular dessa competência.

\footnotetext{
${ }^{38}$ BARRETO, Paulo Ayres. Contribuições - Regime Jurídico, Destinação e Controle, São Paulo: Noeses, 2006. p. 34.

${ }^{39}$ VELLOSO, Andrei Pitten. Conceitos e competências tributárias. São Paulo: Dialética, 2005. p. 25.
} 


\subsubsection{ABERTURA SEMÂNTICA E CONCEITOS E TIPOS CONSTITUCIONAIS}

Vencida a Teoria Legalista, sob o argumento de que legislador constituinte não quis e não deixou total margem discricionária para instituição de impostos e contribuições, sabemos que os signos constitucionais são vinculantes e limitadores. Agora, resta-nos descobrir, então, em que medida eles são vinculantes e limitadores da atividade legiferante.

Destarte, os signos constitucionais devem ser compreendidos como tipos ou conceitos constitucionais? Antes de respondermos diretamente essa questão, por uma questão de didática, cabe-nos apontar qual sentido adotamos para essas expressões.

\subsubsection{TIPO E PENSAMENTO TIPOLÓGICO}

Notadamente no âmbito do Direito Penal e Tributário, o significado de "tipo", muitas vezes muitas vezes adjetivados de "cerrado" ou "fechado", não raro é admitido como noção de uma descrição normativa com alto teor de seletividade e taxatividade ${ }^{40}$.

Tal concepção, inicialmente desenvolvida pelo penalista alemão Beling nas primeiras décadas do século passado, tem por característica ser algo de acromático, incolor, meramente descritivo, despojado de qualquer conteúdo valorativo ${ }^{41}$. $\mathrm{O}$ tipo, nessa visão, seria expediente técnico-legal, descrição neutra (não valorativa), estritamente objetiva e externa, independente dos demais aspectos do delito (antijuridicidade e culpabilidade) e insuficiente para sua configuração ${ }^{42}$.

No âmbito do Direito Tributário, Alberto Xavier, influenciado pela primeira edição da conhecida obra de Karl Larenz, Metodologia da Ciência do Direito, foi quem mais difundiu entre nós esse sentido ${ }^{43}$.

Note-se que, nessa visão tipológica, o aplicador da lei ficaria tolhido de lançar mão de juízo de valor, uma vez que a hipótese legal (o tipo), em face de inúmeros acontecimentos de possível ocorrência no mundo fenomênico, já teria selecionado todas

\footnotetext{
${ }^{40}$ Para o penalista Paulo José da Costa Júnior, "o tipo, enquanto entidade normativa, deve ser determinado quanto ao seu conteúdo e taxativo quanto à sua aplicação concreta." (COSTA JÚNIOR, Paulo José da. Direito Penal: curso completo. 7.ed. São Paulo: Saraiva, 2000. p. 29.)

${ }^{41}$ Cf. COSTA JÚNIOR, Paulo José da. Direito Penal: curso completo. 7.ed. São Paulo: Saraiva, 2000. p. 29.

42 Cf. DERZI, Misabel de Abreu Machado. Direito Tributário, direito penal e tipo. São Paulo: Editora Revista dos Tribunais, 1988. p. 122.

${ }^{43}$ Cf. TORRES, Ricardo Lobo. Tratado de Direito Constitucional Financeiro e Tributário. Valores e Princípios Constitucionais Tributários. Vol. II. Rio de Janeiro, Editora Renovar: 2005. p. 471.
} 
(ou quase todas) as propriedades do evento eleito para compor a norma jurídica. Dar-se-ia subsunção quase que automática, cabendo ao aplicador apenas um juízo de fato.

Todavia, essa acepção de "tipo" é passível de críticas, sob duas perspectivas:

(i) a utilização dessa acepção teria sido superada, inclusive no âmbito da dogmática jurídica alemã, onde se iniciou o estudo do tipo; e, em se tratando da doutrina ibérica e latino-americana, seria resultado de um infeliz emprego da expressão alemã Tatbestand ${ }^{44}$, fato que ainda provocaria confusões terminológicas com o sentido de conceito; e

a aplicação do direito sempre exige, em maior ou menor grau, uma valoração subjetiva.

Por conta dessas ressalvas feitas por abalizada doutrina, adotaremos aqui outra noção de tipo.

Uma simples (mas precisa) idéia sobre tipo é encontrada na seguinte afirmação de Ricardo Lobo Torres: "o tipo representa a média ou a normalidade de uma determinada situação concreta, com as suas conexões de sentido." 45

Nessa esteira, Misabel Derzi assim o enxerga:

“(...) o raciocínio é dito "tipificante”, na medida em que as características individuais, de cada caso isolado, são postas de lado na aplicação da lei, passando-se a considerar o que é freqüente ou médio, como padrão. (....) Tipo, nessa acepção, não será sinônimo de Tatbestand, tampouco tem sentido de ordem, cujas características, interpenetrando-se, não são rígidas, mas graduáveis e fluidas." 46

Vê-se, portanto, que o tipo é o estado de possuir características típicas, qualidades comuns e frequentes num determinado contexto factual. Tais características típicas representam o núcleo do tipo, sendo irrelevantes as demais características. A propósito, até mesmo o núcleo não se revela fixo ou rígido, podendo determinadas características que o compõe ser renunciáveis ${ }^{47}$.

\footnotetext{
${ }^{44}$ Sobre esse último aspecto, eloquente é a seguinte afirmação de Misabel Derzi: "É que a palavra alemã Tatbestand foi traduzida, impropriamente, por tipo." (DERZI, Misabel de Abreu Machado. Direito Tributário, direito penal e tipo. São Paulo: Editora Revista dos Tribunais, 1988. p. 114.)

${ }^{45}$ TORRES, Ricardo Lobo. Tratado de Direito Constitucional Financeiro e Tributário. Valores e Princípios Constitucionais Tributários. Vol. II. Rio de Janeiro, Editora Renovar: 2005. p. 469 e 470.

${ }^{46}$ DERZI, Misabel de Abreu Machado. Direito Tributário, direito penal e tipo. São Paulo: Editora Revista dos Tribunais, 1988. p. 46.

47 “(...) Entende Strache que o tipo, diferentemente do conceito, permite uma evolução: com o correr do tempo, é possível que algumas características típicas passem a predominar sobre outras, que podem perder sua força ou até desaparecer, sendo substituídas por outras que, naturalmente, também podem se fortalecer a ponto de substituir as primeiras." (SCHOUERI, Luís Eduardo. Discriminação de Competências e
} 
Parece-nos, portanto, ser o tipo flexível e, normalmente, mais aberto se comparado com o conceito, dado que, no primeiro, dá-se relevo a seu núcleo (de características típicas), em detrimento das bordas que delimitariam a sua atuação. $O$ núcleo, em maior ou menor grau, é facilmente identificável no tipo por meio de características frequentes da situação em destaque, ao passo que seus contornos são, muitas vezes, insignificantes.

\subsubsection{DISCRIMINAÇÃO DE COMPETÊNCIAS E CONCEITOS E TIPOS}

O pensamento tipológico tem seus adeptos no âmbito da dogmática do Direito Tributário Brasileiro. Ricardo Lobo Torres, ao discorrer sobre a adequação do fato gerador concreto ao abstrato, afirma que isso pode ocorrer de três maneiras, quais sejam: (i) por meio de subsunção, quando o conceito do fato ocorrido se qualifica de acordo com a interpretação do conceito determinado ou indeterminado; (ii) por meio de discricionariedade, quando, depois de interpretar os conceitos indeterminados acoplados às cláusulas discricionárias constantes da regra tributária, a autoridade administrativa age nos limites da decisão equitativa; (iii) por meio da tipificação, quando o conceito do tipo apreendido na realidade se ordena segundo o conceito-tipo descrito na norma tributária ${ }^{48}$.

Fernando Aurélio Zilveti dá grande relevo ao pensamento tipológico no processo de positivação do direito, na medida em que se privilegiariam valores como praticidade e justiça. São suas as seguintes palavras:

“A elaboração normativa se faz de modo 'tateante', como procurando definir algo na penumbra. (...) O tipo é, então, a forma de pensar adequada para a construção da norma abstrata. A norma surge como fruto de valorações ainda por serem definidas. Não há, porém, fixação definitiva por meio de conceitos fechados, mas, sim, tipos que mantêm núcleo rígido e halo incerto, indeterminado ou ainda por determinar." 49

Competência Residual. In: Direito Tributário: Estudos em Homenagem a Brandão Machado. São Paulo: Dialética, 1998.p. 110)

${ }^{48}$ Cf. TORRES, Ricardo Lobo. Tratado de Direito Constitucional Financeiro e Tributário. Valores e Princípios Constitucionais Tributários. Vol. II. Rio de Janeiro, Editora Renovar: 2005. p. 498.

49 ZILVETI, Fernando Aurélio. Obrigação Tributária - Fato Gerador e Tipo. São Paulo: Quartier Latin, 2009. p. 214. 
No que toca especificamente à discriminação de competências tributárias, Luís Eduardo Schoueri acredita que o constituinte, valendo-se dos tradicionais impostos introduzidos nos Sistemas Constitucionais pretéritos, não teve a pretensão de elencar limites rígidos, i.e., impor conceitos. Para o eminente Professor, “(...) sabia ele (o constituinte) que se tratava de expressões fluidas, que por vezes implicariam uma interpenetração, possibilitando, até mesmo, o nascimento de conflitos de competências" ${ }^{\text {"50 }}$. Daí porque a regra do artigo 146, I, do Texto Maior ${ }^{51}$ que conferiu ao legislador complementar disciplinar os conflitos de competência não totalmente superados pela CF/89. Assim, conclui Schoueri, Titular da Cadeira de Direito Tributário da Faculdade de Direito da Universidade de São Paulo, que ao legislador complementar - e não ao interprete da Constituição - caberia se valer de conceitos no mister de solucionar tais conflitos de competências.

Em um trabalho doutrinário mais recente, Luís Eduardo Schoueri, mantendo coerência em seu pensamento tipológico, afirma que a expressão propriedade, enquanto materialidade do IPTU, não se restringiria apenas à acepção que o Direito Civil emprega. Por conta disso, uma determinação constante do CTN, segundo a qual o imposto municipal incidirá também sobre a posse ou domínio útil, não mereceria censuras de nenhuma ordem $^{52}$.

No âmbito do STF, o Ministro Eros Grau, também Titular das Arcadas, reconheceu - em seu voto vencido por ocasião do julgamento do RE 390.840-MG que tratava da compatibilidade entre a base de cálculo da COFINS, prevista na Lei no 9.718/98, e o signo "faturamento", previsto no artigo 195 da CF/88 - que tal expressão, em verdade, equivaleria a conceito jurídico tipológico (fattispecie $)^{53}$.

Todavia, de maneira diversa pensam outros eminentes juristas.

\footnotetext{
50 SCHOUERI, Luís Eduardo. Discriminação de Competências e Competência Residual. In: Direito Tributário: Estudos em Homenagem a Brandão Machado. São Paulo: Dialética, 1998. p. 112.

51 “Art. 146. Cabe à lei complementar: I - dispor sobre conflitos de competência, em matéria tributária, entre a União, os Estados, o Distrito Federal e os Municípios; (...)”

52 SCHOUERI, Luís Eduardo. O mito do Lucro Real na Passagem da Disponibilidade Jurídica para a Disponibilidade Econômica. In: MOSQUERA, Roberto Quiroga. LOPES, Alexsandro Broedel (coords.). Controvérsias Jurídico-Contábeis (aproximações e distanciamentos). São Paulo, Dialética, 2010. p. 249.

53 "Os conceitos jurídicos tipológicos (fattispecie) são expressões da história e indicam os ideais dos indivíduos e grupos, povos e países; ligam-se a esquemas e elaborações de caráter; à história do Estado e à estrutura econômica; a orientações filosóficas e a concepções do mundo. Referem-se a fatos típicos da realidade. Aí encontramos conceitos cujos termos são, v.g., boa-fé, bom pai de família, coisa, bem, causa, dolo, culpa, erro. Atribuir significado a esses termos equivale à identificação das espécies de fato alcançadas por um texto normativo. Os conceitos jurídicos tipológicos (fattispecie), também ditos indeterminados, em verdade não são conceitos, mas noções."
} 
Roberto Quiroga Mosquera, em sua festejada monografia sobre o conceito constitucional de renda, amparado pela rigidez de nosso Sistema Constitucional Tributário, expressa categoricamente que “(...) a repartição da aptidão para a criação de tributos por parte das pessoas políticas é expressa, taxativa e rígida, não havendo margem alguma de liberdade para o legislador infra-constitucional."

Outro Professor das Arcadas que sublinha o pensamento conceitual é Paulo Ayres Barreto. Para ele, de nada valeria uma rígida discriminação de competência para, ulteriormente, conceder ao legislador tamanha liberdade para estabelecer seus contornos ${ }^{55}$.

Nesse mesmo sentido, Misabel Derzi diz ser o tipo inadaptável ao sistema rígido de discriminação de competência tributária. Para a Professora mineira, não há como conviver, em nosso Sistema Constitucional, o pensamento tipológico, no qual prevalecem relações comparativas do "mais ou menos" ou "tanto mais... quanto menos",56.

Do que até aqui se expôs, pode ter ficado a impressão de que existem duas formas de pensamento irremediavelmente inconciliáveis e completamente antagônicas no que toca ao tema da discriminação constitucional de competências tributárias. Se essa preliminar impressão estiver correta, o intérprete teria, necessariamente, de escolher por trilhar um caminho (tipológico) ou outro (conceitual).

Advertimos, porém, que, pelo menos em nosso ponto de vista, tal impressão deve ser rechaçada.

Até mesmo Misabel Derzi, que, como vimos há pouco, não admite a predominância do pensamento tipológico na discriminação de competências tributárias no Direito Constitucional pátrio, leciona o seguinte: "Indagar se o Direito Tributário contém tipos ou conceitos fechados, como alternativas que se excluem, parece-nos inadequado. $\mathrm{O}$ certo será indagar pela predominância de uma ou outra forma de pensamento." 57

Portanto, pode-se dizer que uma radical dicotomia tipo/conceito não tem razão de existir em sede de discriminação de competências tributárias.

Em primeiro lugar, não há que se perder de vista que nem mesmo os conceitos determinados - mais fechados se comparados ao tipo - escapam dos vícios de linguagem

\footnotetext{
${ }^{54}$ MOSQUERA, Roberto Quiroga. O Conceito Constitucional de Renda e Proventos de Qualquer Natureza. Dissertação. Mestrado. Pontifícia Universidade Católica de São Paulo, 1996. p. 91.

${ }^{55} \mathrm{O}$ eminente Professor questiona incisivamente: "Teria ele elaborado uma discriminação de competências para nada discriminar? Teria prescrito para nada prescrever? Teria atuado para não produzir resultados?" (BARRETO, Paulo Ayres. Elisão Tributária: Limites Normativos, São Paulo: USP, 2008. p. 73.)

${ }^{56}$ Cf. DERZI, Misabel de Abreu Machado. Direito Tributário, direito penal e tipo. São Paulo: Editora Revista dos Tribunais, 1988. p. 102.

${ }^{57}$ DERZI, Misabel de Abreu Machado. Direito Tributário, direito penal e tipo. São Paulo: Editora Revista dos Tribunais, 1988. p. 83.
} 
como ambiguidade e vaguidade semântica. O direito, cravado em linguagem (prescritiva) que é, não está imune a esses vícios de linguagem, de forma que é lícito afirmar que, em maior ou menor intensidade (i.e., se tipos ou conceitos determinados), a indeterminabilidade é característica marcante da linguagem e, por consequência, do sistema jurídico.

Melhor explorando essa questão, é interessante observar o ponto de vista de Humberto Ávila. Embora, num primeiro momento, ele reconheça uma diferença lógica entre os procedimentos de tipo (correlação) e conceito (subsunção), ulteriormente afirma que não há diferença relevante na forma de aplicação do direito, seja no pensamento tipológico, seja no conceitual. Para ele, "a correlação representa também um 'procedimento de alternativas mutuamente excludentes'. 'Ou' a consequência jurídica se dá, 'ou' ela não se dá. No final do processo de aplicação do Direito não existe outra possibilidade." 58

Conclui o Professor gaúcho que o tipo não representa nenhuma forma autônoma de pensamento que possa ser confrontada com o conceito, de maneira que seria legítimo asseverar que a discussão sobre conceito e tipo só pode ser um problema aparente $^{59}$.

Assim, perdendo força a preliminar impressão de que haveria uma radical dicotomia entre tipo e conceito, podemos agora afirmar que, em nossa opinião, os signos adotados pela $\mathrm{CF} / 88$ para discriminação de competências tributárias possuem diferentes níveis de indeterminação, podendo alguns se apresentarem na forma de conceitos determinados e outros na de tipos ${ }^{60}$.

Quanto à predominância de um pensamento ou outro, quer-nos parecer que, pelo menos em nosso Sistema Constitucional, deve o intérprete privilegiar o pensamento conceitual (o que não significa excluir a possibilidade de existirem tipos).

Não se pode admitir, aprioristicamente, que o constituinte pretendeu apenas inserir tipos, dando ampla liberdade para o legislador infraconstitucional disciplinar os contornos da competência dos entes da Federação. No mínimo, por dois motivos: (i) pela rigidez que o constituinte dispensou ao Sistema Tributário Nacional, seja para proteger o modelo Federativo que ele desejava, seja pela insistente preocupação com a segurança

\footnotetext{
58 ÁVILA, Humberto. Sistema Constitucional Tributário. 4.ed. São Paulo: Saraiva: 2010. p. 187.

${ }^{59}$ Cf. ÁVILA, Humberto. Sistema Constitucional Tributário. 4.ed. São Paulo: Saraiva: 2010. p. 204.

60 A propósito, Misabel Derzi observa argutamente que a diferença entre tipo e conceito é gradativa, existindo uma série infinita de transições intermediárias. (DERZI, Misabel de Abreu Machado. Direito Tributário, direito penal e tipo. São Paulo: Editora Revista dos Tribunais, 1988. p. 84.)
} 
jurídica e previsibilidade em prol dos contribuintes $^{61}$; e (ii) pelo fato de que os signos empregados pelo constituinte, embora não escapem dos vícios inerentes à linguagem, apresentam um grau de determinação relativamente elevado ${ }^{62}$.

Não deve o intérprete manipular os signos utilizados pelo constituinte e extrair deles somente o núcleo que o compõe, ignorando que, em verdade, na maioria das vezes, encontrará elementos limitadores do conteúdo semântico. Ressalve-se, no entanto, que seria ingênua pretensão esperar um conceito absolutamente fechado, eis que sempre haverá margem para a indeterminabilidade na aplicação do direito.

Por outro lado, é de se admitir também que certos signos utilizados pelo constituinte apresentam relevante grau de indeterminabilidade, razão pela qual, nesses casos em que o tipo ou conceitos indeterminados possivelmente estão presentes, a melhor solução encontrada pelo constituinte foi delegar poderes para o legislador complementar (artigo 146, I, da CF/88), cuja função - como bem nos alertou Luís Eduardo Schoueri - é trazer contornos mais precisos dos signos constitucionais.

Mesmo para Andrei Pitten Velloso, defensor do pensamento conceitual no que toca à discriminação de competências tributárias, há certos casos em que o constituinte deixou ampla possibilidade semântica, sendo o exemplo mais eloqüente o imposto sobre grandes fortunas. Para ele, "os enunciados integrantes desse subsistema são compostos por termos e expressões que apresentam diferentes graus de precisão, o que, aliás, é característico de qualquer texto jurídico." 63

Em suma, acreditamos que o constituinte introduziu signos de diferentes níveis de indeterminabilidade, não sendo lícito afirmar, aprioristicamente, que todos eles se apresentem na forma de tipos. Também não chegamos ao extremo de afirmar que o exegeta se deparará com conceitos tão determinados a ponto de qualificá-los como fechados ou cerrados. É possível que, durante a tarefa de encontrar significados aos signos eleitos pelo constituinte, o exegeta se encontre diante de alto grau de imprecisão, cuja solução encontrada pelo legislador constituinte foi delegar à legislação complementar a função de solucionar conflitos de competências.

\footnotetext{
61 "O conceito determinado e fechado (tipo no sentido impróprio), ao contrário, significa um reforço à segurança jurídica, à primazia da lei, à uniformidade de tratamento dos casos isolados, em prejuízo da igualdade, da funcionalidade e adaptação da estrutura normativa às mutações sócio-econômicas." (DERZI, Misabel de Abreu Machado. Direito Tributário, direito penal e tipo. São Paulo: Editora Revista dos Tribunais, 1988. p. 84.)

62 Quanto a esse aspecto, tem a mesma opinião VELLOSO, Andrei Pitten. Conceitos e competências tributárias. São Paulo: Dialética, 2005. p. 148.

${ }^{63}$ Cf. VELLOSO, Andrei Pitten. Conceitos e competências tributárias. São Paulo: Dialética, 2005. p. 149.
} 


\section{A CONSTRUÇÃO DO SIGNIFICADO DE RENDA ${ }^{64}$}

A seguinte advertência de Humberto Ávila traduz o desafio a ser enfrentado a partir daqui: “(...) a mera afirmação de que o conceito utilizado pela Constituição deve ser respeitado não resolve a questão crucial de saber qual conceito, entre todos aqueles possivelmente utilizáveis, foi efetivamente utilizado pela Constituição."65

Ora, se antes propugnamos que o legislador infraconstitucional não dispõe de ampla liberdade para estabelecer os contornos semânticos inerentes aos signos constitucionais, inclusive porque eles não sofrem, na maioria das vezes, de insuperável indeterminação, não poderíamos deixar de, a partir daqui, enfrentar a (tormentosa) problemática jurídica sobre a construção de tais conteúdos semânticos, notadamente o concernente ao imposto de renda.

Enfatizamos construção porque (i) trata-se de trabalho de interpretação jurídica $^{66}$ e (ii) “(...) a interpretação do direito é constitutiva, e não simplesmente declaratória."

E, se assim é, advertimos que, nesse mister, o exegeta certamente se encontrará diante de vícios de linguagem, como a vaguidade e a ambiguidade semântica ${ }^{68}$. Não poderia ser diferente, eis que, afinal de contas, se o direito deve ser tomado como camada linguística vazada em termos prescritivos ${ }^{69}$, os vícios de linguagem também são problemas que perturbam os aplicadores e observadores do direito. Assim, terá o interprete de eleger, dentre as várias possibilidades existentes, o conteúdo semântico consentâneo com o

\footnotetext{
${ }^{64}$ Observamos que, em verdade, o constituinte empregou, no artigo 153, III, a expressão renda e proventos de qualquer natureza. Com o objetivo de facilitar a leitura do presente trabalho, muitas vezes iremos nos referir apenas ao signo renda, suprimindo a expressão proventos de qualquer natureza. Em momento oportuno, faremos devida distinção.

${ }_{65}^{6}$ ÁVILA, Humberto. Sistema Constitucional Tributário. 4.ed. São Paulo: Saraiva: 2010. p. 212.

${ }^{66}$ "Se habla de definición en relación a vocablos y sintagmas; se habla de interpretación en relación (también) a enunciados: pero la actividad intelectual (determinación del significado de expresiones lingüísticas) es la misma" (GUASTINI, Riccardo. Distinguiendo - Estúdios de teoria y metateoría del derecho. Barcelona: Gedisa, 1999. p. 203.)

${ }^{67}$ GRAU, Eros Roberto. Ensaio e Discurso sobre a Interpretação/Aplicação do Direito. 5. ed. São Paulo: Malheiros, 2009. p. 26. Nesse mesmo sentido, Humberto Ávila doutrina: “(...) pode-se afirmar que o intérprete não só constrói, mas reconstrói sentido, tendo em vista a existência de significados incorporados ao uso linguístico e construídos na comunidade do discurso." (ÁVILA, Humberto. Teoria dos Princípios. Da definição à aplicação dos princípios jurídicos. 11.ed. São Paulo: Malheiros, 2010. p. 33.)

68 "É nele (no plano semântico) que lidamos com os problemas de vaguidade, ambiguidade e carga valorativa das palavras e que estabelecemos a ponte que liga a linguagem normativa à conduta intersubjetiva que ela regula." (CARVALHO, Aurora Tomazini de. Curso de Teoria Geral do Direito: o constructivismo lógicosemântico. São Paulo: Noeses, 2009. p. 157.)

${ }^{69}$ Cf. CARVALHO, Paulo de Barros. Direito Tributário, linguagem e método. São Paulo: Noeses, 2008. p. 198.
} 
sistema jurídico ${ }^{70}$, assim como identificar contornos ao núcleo semântico do signo estudado.

\subsection{ACEPÇÃO DE BASE DE RENDA}

Andrei Pitten Velloso, em sua excelente obra sobre Conceitos e Competências Tributárias, apresenta o seguinte quadro sobre as várias possibilidades semânticas dos conceitos constitucional-tributários em função de sua origem ${ }^{71}$ :

Conceitos autônomos $\left\{\begin{array}{l}\text { Autônomos stricto sensu } \\ \text { Modificados }\left\{\begin{array}{c}\text { Expressamente } \\ \text { Tacitamente }\end{array}\right.\end{array}\right.$

Conceitos recepcionados $\left\{\begin{array}{l}\text { Jurídico } \\ \text { Extrajurídico }\end{array}\right.$

Com efeito, o presente capítulo tem por objeto a construção do significado do signo renda, o que nos possibilitará classificá-lo em alguma das espécies apontadas por Andrei Pitten Velloso.

Pois bem. Os conceitos autônomos stricto sensu seriam aqueles construídos sem nenhum suporte de noções previamente existentes. Em suas palavras, "se o conceito for formado sem tomar por base algum conceito preexistente, estar-se-á tratando de um conceito autônomo stricto sensu."72 Também seria o caso, v.g., de um conceito definido expressamente pela própria Constituição, ou o caso de um conceito tradicionalmente constitucional, como oportunamente nos lembram os Professores lusos Canotilho e Vital Moreira $^{73}$. O próprio Andrei Pitten Velloso, porém, admite não vislumbrar, no Texto da $\mathrm{CF} / 88$, ocorrência dessa espécie de conceito na distribuição de competências tributárias ${ }^{74}$.

\footnotetext{
70 "Quando se trate de conceito aberto por ambiguidade seu preenchimento é procedido também mediante a consideração do contexto em que inserido". (GRAU, Eros Roberto. Ensaio e Discurso sobre a Interpretação/Aplicação do Direito. 5. ed. São Paulo: Malheiros, 2009. p. 240.)

${ }^{71}$ VELLOSO, Andrei Pitten. Conceitos e competências tributárias. São Paulo: Dialética, 2005. p. 262.

${ }^{72}$ VELLOSO, Andrei Pitten. Conceitos e competências tributárias. São Paulo: Dialética, 2005. p. 307.

${ }^{73}$ Fundamentos da Constituição. Coimbra: Coimbra Editora, 1991. p. 54.

${ }^{74}$ Cf. VELLOSO, Andrei Pitten. Conceitos e competências tributárias. São Paulo: Dialética, 2005. p. 308.
} 
Parece claro afirmar, ainda que num estágio meramente preliminar, que renda não poderia estar aqui classificado, tendo em vista as inúmeras significações extraídas desse signo em mais de uma seara, como demonstraremos com mais vagar no curso do presente estudo.

Por outro lado, os conceitos recepcionados seriam formados a partir de conceitos preexistentes ao Texto Constitucional, sejam aqueles consagrados na linguagem do direito positivo e/ou pela metalinguagem da ciência do direito (conceitos recepcionados jurídicos), sejam em outras searas (conceitos recepcionados extrajurídicos).

Excluindo a possibilidade de ser renda um conceito autônomo stricto sensu, restaria apenas classificá-lo em conceito jurídico ou extrajurídico. Assim procedendo, chegaremos à acepção de base do signo renda.

Todavia, só isso não basta. É imprescindível avaliar se a acepção de base (conceito jurídico ou extrajurídico) foi modificada, expressa ou tacitamente, pelo Texto da $\mathrm{CF} / 88^{75}$. Se assim for, torna-se um conceito autônomo modificado (expressa ou tacitamente).

Eis, portanto, a metodologia para a construção do alcance e do sentido do signo renda: verificação de sua acepção de base e posterior confirmação de sua transformação, ou não, pela ordem constitucional. É o que nos indica também Paulo Ayres Barreto ao asseverar:

“Os signos constitucionais, qualificadores do limite para o exercício da competência tributária, devem ser considerados de acordo com sua acepção de base. (...) Posta uma nova ordem constitucional, deve-se empreender esforço para identificar o sentido dos conceitos nela referidos, adotado majoritariamente pela comunidade jurídica. Realizando o esforço de reconhecer esse conceito, impõe-se, ato contínuo, a avaliação de sua incorporação pela nova ordem ou de sua transformação, nos termos por ela estabelecidos."76

Por meio dessa metodologia, alcançaremos nossos objetivos: identificar o significado de renda pertinente ao Sistema Tributário Nacional e, assim, classificá-lo

\footnotetext{
75 "Mesmo que a incorporação seja nítida e aparentemente indiscutível, o trabalho interpretativo somente pode ser encerrado após a constatação de que a Constituição não se afastou, no enunciado específico, do significado pré-constitucional. Por isso, não há como se tratar de conceitos constitucionais sem se enfocar os conceitos autônomos". (VELLOSO, Andrei Pitten. Conceitos e competências tributárias. São Paulo: Dialética, 2005. p. 302 e 303.)

${ }^{76}$ BARRETO, Paulo Ayres. Elisão Tributária: Limites Normativos, São Paulo: USP, 2008. p. 76 e 77.
} 
como: (i) conceito recepcionado jurídico, (ii) conceito recepcionado extrajurídico ou (iii) conceito autônomo modificado.

\subsubsection{ACEPÇÕES COMUNS}

Dissemos alhures, com supedâneo nas lições de Paulo de Barros Carvalho ${ }^{77}$, ser a linguagem comum demasiadamente aberta quanto a seus contornos e ambígua quanto a seus significados. No que tange ao signo renda, a ambiguidade resta evidente mesmo a partir de uma preliminar e superficial leitura dos dicionários. No vernáculo pátrio, quer tanto significar "1. Produto anual ou mensal de propriedades rurais ou urbanas, de bens móveis ou imóveis, de benefícios, capitais em giro, empregos, inscrições, pensões etc.; produto, receita, rendimento", como "2. preço de aluguel” ou "3. Rendimento líquido depois de deduzidas as despesas materiais" 78 .

Não é incomum ouvirmos que "o tal trabalhador tem renda mensal de R\$1.000,00"; que "Fulano vive de renda"; ou que "a renda do Beltrano é o comércio". Na

\footnotetext{
${ }_{77}^{77}$ CARVAlHO, Paulo de Barros. Direito Tributário, linguagem e método. São Paulo: Noeses, 2008. p. 56 78 "renda 1
}

ren.da 1

sf (der regressiva de render) 1 Produto anual ou mensal de propriedades rurais ou urbanas, de bens móveis ou imóveis, de benefícios, capitais em giro, empregos, inscrições, pensões etc.; produto, receita, rendimento. 2 Preço de aluguel. 3 Rendimento líquido depois de deduzidas as despesas materiais. 4 Totalidade dos rendimentos que entram num cofre geral. 5 Rendimento coletável dos cidadãos, que serve de base para o exercício de certos direitos políticos. 6 Importância superior a determinado limite e estabelecida pelas leis fiscais como rendimento da atividade econômica do indivíduo. 7 Série de prestações em dinheiro ou em outros bens, que uma pessoa recebe de outra, a quem foi entregue, para esse efeito, certo capital. sf pl Aluguel de terra. Imposto sobre a renda: tributação sobre pessoas físicas, ou empresas, baseada na renda líquida auferida no ano anterior. R. bruta: a que não sofreu dedução dos gastos feitos para a sua obtenção. R. coletiva: benefício líquido do conjunto da atividade econômica de toda a economia nacional. R. contratual: a que tem por base um contrato, sendo o seu valor fixado por acordo mútuo. R. derivada: a) a que se baseia no esforço alheio, sendo proporcionada por outras pessoas de modo não oneroso; b) renda que não provém imediatamente da produção. R. do Estado: V rendas do Estado. R. estipulada: a que é fixada por contrato, com aluguel, juros, salário etc. R. líquida: a que fica depois de descontados os gastos realizados para a sua obtenção. R. nacional: V renda coletiva. R. originária: a que provém da atividade econômica do próprio indivíduo, por participação imediata na produção. R. per capita: índice econômico que se calcula, em relação a um país, ou parte de um país, dividindo o produto bruto pelo número de habitantes. R. perpétua: juros produzidos por títulos públicos não sujeitos a amortização ou resgate. $\mathrm{R}$. primitiva: $\mathrm{V}$ renda originária. Rendas do Estado, Dir: as auferidas pela União, Estados e municípios, provenientes de contribuições diretas ou indiretas de impostos, taxas ou tributos. R. reais: as rendas da coroa.

\section{renda2}

ren.da2

sf 1 Obra de malha feita com fio de linha, seda, ouro ou prata, apresentando desenhos mais ou menos caprichosos, que serve para guarnecer peças de vestuário, roupas de cama etc. R. da Terra, Reg (Nordeste): o mesmo que renda de bilro. R. de bilro: espécie de renda, feita sobre almofada, na qual se prende o molde de papelão em que se trançam os fios por meio de bilros. R.-do-mar: pequeno animal (Retepora peaniana) que se fixa nas conchas, nas pedras, nos corais. R. valenciana: espécie de renda de fios muito delicados." (Moderno Dicionário da Língua Portuguesa.

http://michaelis.uol.com.br/moderno/portugues/index.php?lingua=portugues-portugues\&palavra=renda .

Acesso em 03/06/2011.) 
primeira acepção, renda quer significar "remuneração total de todas as atividades desenvolvidas por um sujeito, como a do emprego ou a do trabalho" ${ }^{\text {,79 }}$, ao passo que, na segunda, renda tem significado mais restrito, de uma única espécie de remuneração, qual seja: aplicação de capital. Na terceira, renda substitui a própria fonte de produção da remuneração.

Veja-se, portanto, que renda, na acepção comum, pode representar, dentre outras, a remuneração bruta de um indivíduo, a remuneração líquida das despesas necessárias à obtenção da própria remuneração ou apenas certa espécie de remuneração. A ambiguidade semântica é irremediavelmente presente em altíssimo teor. Tanto é assim que Kevin Holmes afirma, “(...) income means different things to different people.”80

A despeito dessa inegável ambiguidade semântica, pode-se extrair, de todas essas acepções, algumas notas comuns ou típicas. Destarte, renda está sempre ligada a um ganho, a uma remuneração, a uma captação ou expectativa de captação monetária definitiva, de modo a sustentar financeiramente um indivíduo e, consequentemente, a integrá-lo ao convívio social. Essas mesmas notas típicas podem ser extraídas do signo provento $^{81}$, o qual também apresenta o vício da ambiguidade semântica. Para José Luís Bulhões Pedreira, “(...) no seu sentido vulgar, tanto a expressão 'renda' quanto a 'proventos' implica a idéia de fluxo, de alguma coisa que entra, que é recebida." ${ }^{, 82}$

Note-se, portanto, que para aqueles que vislumbram - em nosso entender, equivocadamente - serem, necessariamente, os signos constitucional-tributários tipos - e não conceitos -, as acepções comuns de renda seriam importantes - ou definitivos elementos para aferição da autorização constitucional para imposição tributária. Luís Eduardo Schoueri, valendo-se da acepção comum do signo propriedade, fez esse exercício

\footnotetext{
79 "Renda é aquilo que você ganha em um determinado período de tempo - \$2.000 por mês ou \$24.000 por ano”. (PASSOS, Carlos Roberto Martins. NOGAMI, Otto. Princípios de Economia. 5.ed. São Paulo: Thomsom Leaning, 2006. p. 22.)

${ }^{80}$ HOLMES, Kevin. The Concept of Income. A Multi-Disciplinary Analysis. The Netherlands. IBFD Publications BV, 2000. p. 4.

81 "provento

pro.ven.to

sm (lat proventu) Ganho, lucro, proveito, rendimento." ." (Moderno Dicionário da Língua Portuguesa. http://michaelis.uol.com.br/moderno/portugues/index.php?lingua=portugues-portugues\&palavra=provento. Acesso em 08/06/2011.)

82 apud COSTA, Alcides Jorge. Conceito de Renda Tributável. In: MARTINS, Ives Gandra da Silva (coord.). Estudos sobre o Imposto de Renda (Em memória de Henry Tilbery). São Paulo: Resenha Tributária, 1994. p. 27.
} 
para concluir que o IPTU é um imposto sobre bens imóveis - e não sobre a propriedade de bens imóveis (propriedade na acepção consagrada pela Ciência Jurídica) ${ }^{83}$.

O legislador complementar, em vista desses elementos comuns ou típicos, teria - para os adeptos do pensamento tipológico - relevante margem criativa para conceituar a renda juridicamente tributável.

Nesse sentido, prevalecendo o pensamento tipológico, não haveria margem para censura de inconstitucionalidade ao Projeto de Lei Complementar n ${ }^{\circ}$ 104/01, que alteraria o caput do artigo 43 do $\mathrm{CTN}$, definindo o fato gerador do imposto de renda como "a aquisição de disponibilidade econômica ou jurídica de receita ou de rendimento proveniente, a qualquer título, do capital, do trabalho, ou da combinação de ambos." Tivesse sido a Projeto de Lei aprovado em sua integralidade, o imposto de renda seria transformado em verdadeiro imposto sobre receitas ou rendimentos, o que não seria incoerente com os traços típicos de renda extraídos das várias acepções comuns.

Todavia, não podemos perder de vista as premissas adotadas por ocasião do primeiro capítulo deste trabalho. Como já dissemos, embora os diversos signos constitucional-tributários tenham diferentes níveis de vícios semânticos, não pode o intérprete, aprioristicamente, concebê-los como tipos, desprezando-se a possibilidade hermenêutica de melhor precisá-los. O pensamento conceitual - e não tipológico - é mais consentâneo com a rigidez do Sistema Tributário Nacional e nosso modelo Federativo de Estado.

Com o exemplo acima descrito, percebe-se que o legislador complementar, valendo-se da renda enquanto tipo constitucional, teria ampla liberdade para transformar o imposto de renda num verdadeiro imposto sobre as receitas ou vendas de mercadorias ou serviços, invadindo sobremaneira o espaço reservado a outros entes federativos.

Em suma, refutamos a importância das acepções comuns como elemento definitivo para aferir os traços típicos do signo renda e, em última análise, do fenômeno a ser tributado.

Não significa isso, por outro lado, que as acepções comuns não têm importância como um instrumento inicial para construção do sentido dos signos

\footnotetext{
83 “(...) para o leigo, a expressão 'propriedade’é tomada como sinônimo de bem imóvel. Diz-se que Fulano adquiriu a 'propriedade' vizinha. Assim, é perfeitamente possível acreditar que quando o constituinte previu o Imposto sobre a Propriedade Predial e Urbana, não cogitou de um Imposto sobre o Direito de Propriedade Predial e Territorial Urbana, mas sim de um Imposto sobre as Propriedades (leia-se: bens imóveis) Prediais e Territoriais Urbanas." (SCHOUERI, Luís Eduardo. O mito do Lucro Real na Passagem da Disponibilidade Jurídica para a Disponibilidade Econômica. In: MOSQUERA, Roberto Quiroga. LOPES, Alexsandro Broedel (coords.). Controvérsias Jurídico-Contábeis (aproximações e distanciamentos). São Paulo, Dialética, 2010.p. 249.)
} 
constitucional-tributário. Afinal de contas, nos dizeres de Eros Roberto Grau ${ }^{84}$, a linguagem jurídica nutre-se da linguagem comum ou natural ${ }^{85}$. Sobre a importância das linguagens comum e técnica para a construção do sentido e alcance da autorização constitucional para tributação da renda, Roberto Quiroga Mosquera é decisivo: "a palavra 'renda' e a expressão 'proventos de qualquer natureza', insertas no artigo 153 do Texto Constitucional de 1988, são termos linguísticos extraídos da linguagem comum e impregnados de sentido técnico;" $"$.

\subsubsection{TEORIAS ECONÔMICAS E FISCAIS ${ }^{87}$}

A despeito de inúmeros trabalhos e referências ao signo renda por estudiosos das ciências econômicas e financeiras, não se pode dizer que ele tenha sido empregado sempre com o mesmo alcance e significado ${ }^{88}$.

Pelo contrário. Cada estudioso - desde Adam Smith até os estudiosos de tempos mais contemporâneos - tem se utilizado do termo e empregado significados de acordo com o contexto de suas obras, em total prejuízo do uso uniforme da expressão. Tal constatação resta evidente a partir dos ambíguos conteúdos empregados, exemplificativamente, por Smith, Marshall e Fischer ${ }^{89}$. Adam Smith assevera ser renda a riqueza nova que deriva de uma fonte produtora. Marshall e Fischer incluem no conceito

${ }^{84}$ GRAU, Eros Roberto. Ensaio e Discurso sobre a Interpretação/Aplicação do Direito. 5. ed. São Paulo: Malheiros, 2009. p. 225.

85 “(...) quando se empreende a exegese constitucional há, como já assinalado, necessidade de investigação, no mínimo, da própria linguagem. Será imperativo o exame da linguagem comum, dos termos técnicos, as características da linguagem (tais como a vagueza e a ambigüidade), dos usos linguísticos, etc." (VELLOSO, Andrei Pitten. Conceitos e competências tributárias. São Paulo: Dialética, 2005. p. 44.)

${ }^{86}$ MOSQUERA, Roberto Quiroga. O Conceito Constitucional de Renda e Proventos de Qualquer Natureza. Dissertação. Mestrado. Pontifícia Universidade Católica de São Paulo, 1996. p. 39.

${ }^{87}$ Advertimos, preliminarmente, que, por extrapolar o escopo do presente trabalho, discorreremos sobre tais teorias apenas no que julgarmos necessário para atingir nossos objetivos. Não está entre nossas propostas a análise da história do pensamento econômico sobre a renda (mas sim indicar os limites constitucionais para sua tributação). A importância, para este estudo, da análise das teorias econômicas consiste apenas em nos auxiliar na construção da acepção de base de renda. Nesse ponto, Achille Donato Gianinni suporta nosso entendimento ao doutrinar que o sentido econômico de renda serve apenas como núcleo básico do conceito jurídico, mas eles (conceitos econômicos e jurídicos) não coincidem porque a finalidade com que a renda é estudada em cada uma dessas ciências é diversa (apud LEMKE, Gisele. Imposto de Renda - os Conceitos de Renda e de Disponibilidade Econômica e Jurídica. São Paulo: Dialética, 1998. p. 21.) Em nosso trabalho, algumas dessas diferenças ficarão mais explícitas no desenvolvimento do terceiro capítulo, no qual discorreremos sobre as limitações ao exercício da competência tributária, particularmente no que toca ao princípio da capacidade contributiva.

${ }^{88}$ Cf. SAKAKIHARA, Zuudi. Código Tributário Nacional Comentado: doutrina e jurisprudência. In: FREITAS, Vladimir Passos de (coord.). 2.ed. São Paulo: Revista dos Tribunais, 2004. p. 150.

89 Acepções extraídas da obra de Gisele Lemke (Imposto de Renda - os Conceitos de Renda e de Disponibilidade Econômica e Jurídica. São Paulo: Dialética, 1998. p. 17.). 
os serviços que uma pessoa obtém a partir dos bens de sua propriedade, mesmo que eles estejam destinados ao uso próprio.

Contemporaneamente, é sempre lembrado o estudo empreendido pelo jurista argentino Horácio García Belsunce ${ }^{90}$, o qual compendiou e sistematizou o pensamento de diversos autores de diferentes épocas e searas científicas. Além das teorias que denominou de econômicas, discorreu sobre as teorias ditas fiscais, tendo segregado-as em três categorias, quais sejam: (i) teoria da renda-produto, (ii) teoria renda-acréscimo patrimonial e (iii) teorias legalistas.

Mais recentemente, o jurista neozelandês Kelvin Holmes ${ }^{91}$ produziu reconhecido trabalho de fôlego, no qual analisa as várias acepções de renda nas searas econômica, contábil e jurídica.

Seja como for, as teorias da renda-produto e da renda-acréscimo patrimonial têm gozado prestígio, tendo inspirado e contribuído para a elaboração de legislações tributárias de diversos países desde o século $\mathrm{XIX}^{92}$.

Em apertada síntese, para os adeptos da teoria da renda-produto, renda significa resultado de uma fonte econômica da qual ela se origina; por outro lado, pela teoria da renda-acréscimo patrimonial, renda representa o acréscimo patrimonial originário de qualquer fonte, interna ou externa ao patrimônio aumentado ${ }^{93}$. Ambas não escapam a críticas, sendo a mais comum, no que tange à primeira, ao fato de excluir os ganhos alheios à fonte permanente, como o ganho de capital ${ }^{94}$.

No que tange à teoria da renda-acréscimo patrimonial, seu precursor foi o economista alemão Georg von Schanz, que vislumbrou um conceito amplo de renda, aí incluídas todas as entradas que possam ser avaliadas em moeda, inclusive o ganho de capital $^{95}$, independentemente de realização dos lucros ${ }^{96}$. Henry Simons, outro importante defensor dessa teoria, aduz que a renda seria o saldo positivo obtido da soma da renda

\footnotetext{
${ }^{90}$ El concepto de Redito em la Doctrina y en el Derecho Tributário. Buenos Aires, Depalma, 1967.

${ }^{91}$ The Concept of Income. A Multi-Disciplinary Analysis. The Netherlands. IBFD Publications BV, 2000.

${ }^{92}$ Cf. LANG, Joachim. The Influence of Tax Principles on the Taxation of Income From Capital. In: EATLP Congress, Cologne 12-14 June 2003. IBFD, 2003. p. 18.

${ }^{93}$ Cf. OLIVEIRA, Ricardo Mariz de. Fundamentos do Imposto de Renda. São Paulo: Quartier Latin, 2008. p. 81.

${ }^{94}$ Nesse sentido, Luís Eduardo Schoueri (O mito do Lucro Real na Passagem da Disponibilidade Jurídica para a Disponibilidade Econômica. In: MOSQUERA, Roberto Quiroga. LOPES, Alexsandro Broedel (coords.). Controvérsias Jurídico-Contábeis (aproximações e distanciamentos). São Paulo, Dialética, 2010. p. 243.)

95 Cf. LEMKE, Gisele. Imposto de Renda - os Conceitos de Renda e de Disponibilidade Econômica e Jurídica. São Paulo: Dialética, 1998. p. 21.

${ }^{96}$ Cf. POLIZELLI, Victor Borges. O Princípio da Realização da Renda e sua Aplicação no Imposto de Renda das Pessoas Jurídicas. Dissertação. Mestrado. Universidade de São Paulo, 2009. p. 37.
} 
poupada e da renda consumida, isto é, das receitas que foram incorporadas ao patrimônio e determinaram o seu aumento, e das receitas que, tendo sido consumidas no período, não trouxeram nenhum acréscimo de patrimônio, ao final do período considerado ${ }^{97}$. Para o economista norte-americano Robert Murray Haig, renda seria o acréscimo do poder de um indivíduo de satisfazer as suas vontades em um dado período, sendo esse poder consistente de dinheiro ou qualquer coisa suscetível de avaliação em dinheiro ${ }^{98}$.

À junção das noções de renda atribuídas por esses pensadores, a doutrina passou a alcunhar de modelo SHS (Schanz-Haig-Simons) ou conceito fundamental de renda, na expressão utilizada por Kelvin Holmes. Tal modelo inspira-se no tripé composto por (i) acréscimo monetário de riqueza (mesmo que não realizado), (ii) renda imputada (utilização dos bens próprios) e (iii) gastos com bens e serviços (renda psicológica = fluxo de sentimentos de satisfação decorrente de experiências psicológicas intangíveis) ${ }^{99}$.

\subsubsection{O SIGNO RENDA NO CONTEXTO DO DIREITO TRIBUTÁRIO BRASILEIRO PRÉ-CONSTITUCIONAL}

Como bem anota Fabiana Del Padre Tomé, “(...) o legislador emprega linguagem técnica, aproveitando algumas palavras e expressões do domínio científico, mas edificando seu discurso com suporte na linguagem natural." ${ }^{~} 100$ Da leitura do artigo 43 do CTN, diploma legislativo anterior à promulgação da $\mathrm{CF} / 88$ e com força de lei complementar, extrai-se que o legislador, ao definir o fato gerador do imposto de renda, teve como norte as acepções comuns e técnico-econômicas do signo renda, acima ventiladas.

Vejamos:

“Art. 43. O imposto, de competência da União, sobre a renda e proventos de qualquer natureza tem como fato gerador a aquisição da disponibilidade econômica ou jurídica:

\footnotetext{
${ }^{97}$ Cf. SAKAKIHARA, Zuudi. Código Tributário Nacional Comentado: doutrina e jurisprudência. In: FREITAS, Vladimir Passos de (coord.). 2.ed. São Paulo: Revista dos Tribunais, 2004. p. 151.

98 Cf. POLIZELLI, Victor Borges. O Princípio da Realização da Renda e sua Aplicação no Imposto de Renda das Pessoas Jurídicas. Dissertação. Mestrado. Universidade de São Paulo, 2009. p. 37.

${ }^{99}$ Cf. MARTINS, Ricardo Lacaz. A Tributação da Renda Imobiliária. Tese. Doutorado. Universidade de São Paulo, 2009. p. 51.

${ }^{100}$ TOMÉ, Fabiana Del Padre. Exigibilidade do crédito tributário: amplitude e efeitos de sua suspensão. In: VII Congresso Nacional de Estudos Tributários do IBET, 2010, São Paulo. Direito Tributário e os Conceitos de Direito Privado. São Paulo: Noeses, 2010.
} 
I - de renda, assim entendido o produto do capital, do trabalho ou da combinação de ambos;

II - de proventos de qualquer natureza, assim entendidos os acréscimos patrimoniais não compreendidos no inciso anterior."

Vê-se, portanto, que, valendo-se das acepções comuns e técnico-econômicas, o legislador tributário juridicizou uma definição de renda e de proventos de qualquer natureza. Ainda que não tenha prestigiado em sua integralidade uma ou outra teoria econômica ou mesmo uma ou outra acepção comum de renda ou de proventos, fato é que o legislador não partiu do nada. Pelo contrário. Partiu das acepções comuns e técnicoeconômicas. Teve-as, no mínimo, como norte, considerando alguns de seus traços comuns. Dentre as opções políticas de que dispunha, desenhou um e somente um significado de renda e de proventos de qualquer natureza, prestigiando a segurança jurídica, em detrimento da ampla ambiguidade e vagueza semântica que se poderia ter antes da juridicização das expressões em voga.

Tivesse adotado um conceito nitidamente incompatível com as acepções comuns e técnico-econômicas, teria o legislador incorrido em ilegítima atuação ${ }^{101}$ ou, no mínimo, nosso trabalho de investigar a acepção de base do signo renda e da expressão proventos de qualquer natureza teria de tomar outro rumo. Teríamos de menosprezar a definição trazida pelo CTN, sob pena de chegarmos a uma conclusão (ou uma acepção de base) incompatível com o signo empregado pela $\mathrm{CF} / 88$. Isso porque, como bem anotou Ricardo Mariz de Oliveira, “(...) a verdade é que há um sentido semântico mínimo nos termos constitucionais, dentro do qual a lei complementar deve se ater." 102 Pelo bem do mister hermenêutico, assim laborou o legislador, razão pela qual podemos adotar a definição constante do citado codex como a acepção de base do signo constitucional renda e da expressão proventos de qualquer natureza.

Não ignoramos que a definição do CTN não soluciona todas as dúvidas que cercam o tema do aspecto material do imposto de renda, tendo merecido críticas de Brandão Machado neste particular ${ }^{103}$. Porém, deve o intérprete, para identificar os

\footnotetext{
${ }^{101}$ Nesse sentido, Luciano Amaro afirma: “(...) resta também vedado à lei instituidora de tributo promover a alteração do conceito léxico de palavras utilizadas por norma superior para a definição da competência." (AMARO, Luciano. Direito Tributário Brasileiro. 14. ed. São Paulo: Saraiva, 2008. p. 102).

102 OLIVEIRA, Ricardo Mariz de. Fundamentos do Imposto de Renda. São Paulo: Quartier Latin, 2008. p. 174.

103 “O que está no Código vigente não atende à Constituição; urge que se legisle, para que se cumpra o mandamento constitucional, pois também o rigor de uma definição adequada do que pode ser o fato gerador e a base de cálculo e de quem é o contribuinte do imposto de renda constituirá, na verdade, limitaççao ao arbítrio do legislador ordinário (...)" (MACHADO, Brandão. Breve Exame Crítico do Art. 43 do CTN. In:
} 
requisitos para uma tributação constitucional da renda, valer-se de disposições de todo o sistema (o que pretendemos fazer no próximo capítulo).

Ademais, cumpre-nos afirmar que não nos parece que a metodologia aqui empregada para construção do sentido do signo constitucional renda represente uma inadequada interpretação constitucional por meio da legislação infraconstitucional; uma inversão de valores, desprestigiando a supremacia constitucional. Nesse ponto, Reinaldo Pizolio, em proveitoso estudo sobre competência tributária e conceitos constitucionais, apresenta irretocável retórica:

“(...) o legislador constituinte de 1988, para elaborar a Carta Política, não partiu do nada, não iniciou seu caminho de um vácuo normativo e social. Embora tivesse, em termos rigorosos, inaugurando juridicamente o Estado de Direito Brasileiro - aliás, Estado Democrático de Direito - e rompendo, portanto, a ordem jurídica então vigente, debruçou-se sobre a realidade social existente na época e mesmo sobre o ordenamento jurídico infraconstitucional, para ali recolher subsídios, elementos, informações, institutos e conceitos, e utilizá-los na elaboração da então nova Constituição Federal, inclusive com a recepção dos diplomas legais vigentes que não contrariassem os comandos superiores daquela." $" 104$

A propósito, não somos os primeiros a apontar a definição trazida pelo CTN como um importante instrumento para aferição do significado constitucional de renda. Para Ricardo Mariz de Oliveira:

“(...) a Assembléia Constituinte, findada em 1988, encontrou um termo técnico-jurídico - 'renda e proventos de qualquer natureza'- amplamente compreendido e empregado no regime anterior, para cujo emprego e cuja compreensão a definição do art. 43 emprestava papel relevante e definitivo, inclusive não tendo sido afastado em qualquer alegação de inconstitucionalidade perante o Supremo Tribunal do País."

Pois bem. Feitas tais considerações, passemos a desenvolver melhor a definição constante do artigo 43 do CTN. Nesse particular, dois pontos merecem destaque:

MARTINS, Ives Gandra da Silva (coord.). Estudos sobre o Imposto de Renda (Em memória de Henry Tilbery). São Paulo: Resenha Tributária, 1994. p. 124.)

104 PIZOLIO, Reinaldo. Competência Tributária e Conceitos Constitucionais. São Paulo: Quartier Latin, 2006. p. 222.

105 OLIVEIRA, Ricardo Mariz de. Fundamentos do Imposto de Renda. São Paulo: Quartier Latin, 2008. p. 175. 
a expressão disponibilidade jurídica e econômica e as definições de renda e de proventos de qualquer natureza constantes dos incisos do mencionado dispositivo.

No que tange ao primeiro ponto, esclarecemos que ele, ainda hoje, é objeto de discussões doutrinárias, não havendo aceitação unânime do alcance da disponibilidade jurídica e econômica. Tradicionalmente, à expressão disponibilidade jurídica têm-se atribuído o significado de aquisição do direito à renda, ainda que sem sua realização em caixa ou em bens suscetíveis de realização em caixa. Já disponibilidade econômica estaria afeta ao próprio recebimento em caixa ou em bens suscetíveis de realização em caixa. A despeito de toda a controvérsia que gira em torno dessas expressões e de seus mais variados usos pela doutrina pátria, analisaremos, no próximo capítulo, apenas o ponto que nos interessa para o presente estudo, particularmente no que diz respeito à possibilidade, ou não, de a expressão disponibilidade econômica poder abrigar elementos estranhos à noção de patrimônio em seu sentido estritamente jurídico ${ }^{106}$.

Por outro lado, no que diz respeito às definições constantes dos incisos do artigo 43 do CTN, merecem destaques os comentários de Roberto Quiroga Mosquera. O autor, em sua prestigiada monografia sobre o conceito constitucional de renda e de proventos de qualquer natureza, indicou ser a definição do inciso I da espécie denotativa, ou seja, o legislador apontou as coisas que estão inseridas no conceito da palavra, mas não identificou as propriedades e características que representam o objeto definitivo ${ }^{107}$. Por sua vez, no inciso II, que trataria da expressão proventos de qualquer natureza, seria uma definição da espécie conotativa, posto que, aqui sim, o legislador teria discriminado uma propriedade, qual seja: um acréscimo de patrimônio ${ }^{108}$.

Eis o ponto que mais nos interessa neste momento. O signo renda, em conjunto com a expressão proventos de qualquer natureza, representa acréscimo de patrimônio. Com efeito, parece intuitivo aludir a dois marcos temporais. Acréscimo pressupõe comparação entre duas situações temporais distintas. Não há que se pensar em acréscimo num contexto estático. Acréscimo de patrimônio, assim, é aquele verificado entre um marco inicial e outro final.

\footnotetext{
${ }^{106}$ Vide item 3.2.4.

107 Cf. MOSQUERA, Roberto Quiroga. O Conceito Constitucional de Renda e Proventos de Qualquer Natureza. Dissertação. Mestrado. Pontifícia Universidade Católica de São Paulo, 1996. p. 50.

${ }^{108}$ Cf. MOSQUERA, Roberto Quiroga. O Conceito Constitucional de Renda e Proventos de Qualquer Natureza. Dissertação. Mestrado. Pontifícia Universidade Católica de São Paulo, 1996. p. 51.
} 
Com efeito, eis a acepção de base que nos propugnamos a apresentar por ocasião do presente capítulo: acréscimo de patrimônio verificado entre dois marcos temporais.

Não negamos, porém, que tal significado contenha algum grau de indeterminabilidade (aliás, nota comum a todos os signos) e, via de consequência, não solucione todas as dúvidas suscitadas a respeito do imposto em tela. Daí a razão para, no capítulo posterior, abordarmos outros elementos capazes de mitigar referida indeterminabilidade.

De todo modo, podemos afirmar que, seguindo a classificação proposta por Andrei Pitten Velloso, trata-se de - em sua origem pré-constitucional ( $\mathrm{CF} / 88)$ - um conceito jurídico.

\subsection{O TESTE DA CONFIRMAÇÃO DA RECEPÇÃO, NA CONSTITUIÇÃO FEDERAL, DA ACEPÇÃO DE BASE DO SIGNO RENDA}

Descoberta a acepção de base de renda, mister se faz - coerentemente com a metodologia aqui empregada - averiguar se tal acepção foi recepcionada ou transformada pela $\mathrm{CF} / 88$. A confirmar nossa preocupação com esse estágio, Andrei Pitten Velloso consigna:

“(...) quando são investigados os significados dos termos e expressões que a Constituição utiliza para outorgar competências impositivas aos entes políticos e que já possuem significação específica em determinada área do Direito, devese aferir, com base no texto constitucional, se esses vocábulos mantêm o sentido que já possuíam no direito infraconstitucional ou se adquirem novas conotações." 109

Neste trabalho, serão de grande valia as obras que se dedicaram a construir o conceito de renda eminentemente a partir do texto constitucional, como são ótimos exemplos os trabalhos de Roberto Quiroga Mosquera, José Artur Lima Gonçalves e Roque Antônio Carrazza.

Pois bem. Roberto Quiroga Mosquera, em sua monografia sobre o conceito constitucional de renda e proventos de qualquer natureza, aponta ter o Texto

${ }^{109}$ VELLOSO, Andrei Pitten. Conceitos e competências tributárias. São Paulo: Dialética, 2005. p. 101. 
Constitucional mencionado 22 vezes o signo renda ${ }^{110}$. No curso de todas essas menções, o legislador constituinte teria se valido do signo para expressar diversas acepções, como receitas tributárias, ingressos públicos, renda nacional, em sua maioria não condizentes com a atribuição de competência tributária a que alude o artigo 153, III, da CF/88. Dentre as acepções adotadas pelo poder constituinte, o Professor das Arcadas destacou a redação do revogado inciso II, do parágrafo $2^{\circ}$, do artigo $153^{111}$, a qual, no seu entender, expressava um conceito de renda enquanto produto do trabalho, em mais uma definição do tipo denotativa, ou seja, indicação das coisas que estão inseridas no conceito da palavra - e não as propriedades e características que representam o objeto definitivo ${ }^{112}$. Ademais, o artigo 151 , inciso $\mathrm{II}^{113}$, traria outra definição denotativa, expressando ser renda o produto do capital $^{114}$.

No que tange ao signo provento, consta do conceituado trabalho de Roberto Quiroga Mosquera a informação de que o termo aparece 24 vezes no Texto Supremo, concluindo o Professor ter ele a acepção de rendimentos da aposentadoria ${ }^{115}$.

Por fim, destaca a locução adjetiva de qualquer natureza, a qual, em seu entendimento, representa a vontade do legislador constituinte de inserir na competência tributária da União não apenas o produto do trabalho, do capital e da aposentadoria - mas também de outras fontes as quais não nominou expressamente no Texto Supremo ${ }^{116}$.

Vislumbra, por fim, que, tendo o constituinte adotado o patrimônio como índice de tributação, esse deve ser entendido em seu sentido estático e dinâmico. Assim, o imposto de renda seria uma hipótese de tributação do patrimônio sob o ponto de vista dinâmico, ou seja, tributação sobre “(...) fato patrimonial modificativo majorativo, assim entendida a mutação de elementos pertencentes ao patrimônio das pessoas que se qualifica

${ }^{110}$ Cf. MOSQUERA, Roberto Quiroga. O Conceito Constitucional de Renda e Proventos de Qualquer Natureza. Dissertação. Mestrado. Pontifícia Universidade Católica de São Paulo, 1996. p. 54. Vale lembrar que seu trabalho data de 1996, razão pela qual esse número pode não representar a realidade atual em razão das várias emendas constitucionais levadas a efeito desde aquela época.

111 “Art. 153. (...) $\S 2^{\circ}$ (...) II - não incidirá, nos termos e limites fixados em lei, sobre rendimentos provenientes de aposentadoria e pensão, pagos pela previdência social da União, dos Estados, do Distrito Federal e dos Municípios, a pessoa com idade superior a sessenta e cinco anos, cuja renda total seja constituída, exclusivamente, de rendimentos do trabalho."

112 Cf. MOSQUERA, Roberto Quiroga. O Conceito Constitucional de Renda e Proventos de Qualquer Natureza. Dissertação. Mestrado. Pontifícia Universidade Católica de São Paulo, 1996. p. 60 e ss.

113 “Art. 151. (...) II - tributar a renda das obrigações da dívida pública dos Estados, do Distrito Federal e dos Municípios, bem como a remuneração e os proventos dos respectivos agentes públicos, em níveis superiores aos que fixar para suas obrigações e para seus agentes;"

114 Cf. MOSQUERA, Roberto Quiroga. O Conceito Constitucional de Renda e Proventos de Qualquer Natureza. Dissertação. Mestrado. Pontifícia Universidade Católica de São Paulo, 1996. p. 65 e ss.

${ }^{115}$ Cf. MOSQUERA, Roberto Quiroga. O Conceito Constitucional de Renda e Proventos de Qualquer Natureza. Dissertação. Mestrado. Pontifícia Universidade Católica de São Paulo, 1996. p. 68 e ss.

116 Cf. MOSQUERA, Roberto Quiroga. O Conceito Constitucional de Renda e Proventos de Qualquer Natureza. Dissertação. Mestrado. Pontifícia Universidade Católica de São Paulo, 1996. p. 75. 
como acréscimo (...). ${ }^{, 117}$ Eis o imposto de renda e sua intrínseca relação com o acréscimo de patrimônio verificado entre dois lapsos temporais.

Conclui o respeitado Professor da Faculdade de Direito da Universidade de São Paulo ser o artigo 43 do CTN compatível com a CF/88, fazendo apenas uma ressalva quanto à expressão proventos de qualquer natureza, a qual, pela redação do CTN, seria tudo aquilo que não renda; entretanto, proventos, na acepção empregada pela $\mathrm{CF} / 88$, equivale a um tipo de rendimento ${ }^{118}$. Todavia, essa pequena ressalva apontada não macula, em essência, a significação que se extrai do artigo 43 do CTN, o qual reza ser o fato gerador do imposto o acréscimo de patrimônio.

Repare-se que o trabalho desempenhado por Roberto Quiroga Mosquera consubstanciou o que podemos chamar - incentivos por Humberto Ávila ${ }^{119}$ - de delimitação positiva da regra de competência. Em termos simples, tratou-se de saber o que é renda.

Por outro lado, na delimitação negativa, o intérprete, para saber o que é renda, busca aferir o que não é, por meio de análise de outros conceitos próximos. Ou, nas palavras de Humberto Ávila, “o conceito de renda pode ser extraído da Constituição também por meio da sua distinção relativamente a outras hipóteses de incidência que a própria Constituição estabelece."

Nesse mister, de grande valia foi a contribuição de José Artur Lima Gonçalves, por meio de seu Imposto sobre a Renda - Pressupostos Constitucionais. O renomado Professor da Pontifícia Universidade Católica de São Paulo, em primeiro lugar, identificou conceitos próximos, como faturamento, patrimônio, capital, lucro, ganho, resultado, etc. Esses conceitos, "de um modo ou de outro, aproximam-se, tangenciam ou influem no conceito de renda." ${ }^{21}$ A partir do cotejo entre todos esses conceitos, o autor conclui ser o conceito pressuposto de renda o "(i) saldo positivo resultante do (ii) confronto entre (ii.a) certas entradas e (ii.b) certas saídas, ocorridas ao longo de um dado (iii) período."122

\footnotetext{
${ }^{117}$ MOSQUERA, Roberto Quiroga. O Conceito Constitucional de Renda e Proventos de Qualquer Natureza. Dissertação. Mestrado. Pontifícia Universidade Católica de São Paulo, 1996. p. 112.

118 Cf. MOSQUERA, Roberto Quiroga. O Conceito Constitucional de Renda e Proventos de Qualquer Natureza. Dissertação. Mestrado. Pontifícia Universidade Católica de São Paulo, 1996. p. 77.

${ }^{119}$ Cf. ÁVILA, Humberto. Conceito de Renda e Compensação de Prejuízos Fiscais. São Paulo: Malheiros, 2011. ps. 32 e 33.

${ }^{120}$ ÁVILA, Humberto. Conceito de Renda e Compensação de Prejuízos Fiscais. São Paulo: Malheiros, 2011. p. 33.

121 GONÇALVES, José Artur Lima. Imposto sobre a Renda - Pressupostos Constitucionais. São Paulo: Malheiros, 2002. p. 177.

${ }^{122}$ GONÇALVES, José Artur Lima. Imposto sobre a Renda - Pressupostos Constitucionais. São Paulo: Malheiros, 2002. p. 179.
} 
Notadamente em razão do elemento saldo positivo, José Artur Lima Gonçalves destaca ser o conceito de renda ligado à noção de plus, de algo a mais, de acréscimo, tendo ele sido consumido ou não ${ }^{123}$.

Esse mesmo trilho metodológico foi percorrido pelo Professor Titular da Pontifícia Universidade Católica de São Paulo, Roque Antônio Carrazza, concluindo - a partir daquilo que chamamos de delimitação negativa da regra de competência - estar renda sempre vinculada a acréscimo patrimonial no tempo ${ }^{124}$. Por fim, ao cotejar o conceito que se extrai da $\mathrm{CF} / 88$ e a definição do artigo 43 do $\mathrm{CTN}$, doutrina não haver divergências, desde que interpretado de modo adequado ${ }^{125}$.

Com efeito, apoiados na melhor doutrina, podemos chegar à conclusão de que a acepção de base de renda não foi infirmada pela $\mathrm{CF} / 88$.

\subsubsection{OS CRITÉRIOS DA UNIVERSALIDADE, GENERALIDADE E PROGRESSIVIDADE}

Após conferir, no inciso III, competência tributária à União para instituir imposto sobre renda e proventos de qualquer natureza, o artigo 153 da $\mathrm{CF} / 88$, agora no parágrafo segundo, prescreve que: "O imposto previsto no inciso III: (...) será informado pelos critérios da generalidade, da universalidade e da progressividade, na forma da lei."

Longe da pretensão de aprofundar a análise desses critérios, interessa-nos aqui saber se eles afirmam ou infirmam a acepção de renda até aqui construída. Ou, em última análise, se a CF/88 recepciona ou transforma a acepção de base de renda.

Pois bem. Podemos afirmar que a doutrina pátria tem conferido acepções convergentes a esses critérios constitucionais. Eivany Antonio da Silva relaciona a universalidade à tributação do total das rendas dos contribuintes, enquanto que o princípio da generalidade estaria afeto à tributação de todos os contribuintes ${ }^{126}$. Nesse mesmo sentido, posiciona-se Roque Antônio Carrazza ${ }^{127}$ e Ricardo Mariz de Oliveira. Este último

\footnotetext{
${ }^{123}$ Cf. GONÇALVES, José Artur Lima. Imposto sobre a Renda - Pressupostos Constitucionais. São Paulo: Malheiros, 2002. p. 180.

${ }^{124}$ Cf. CARRAZZA, Roque Antônio. Imposto sobre a Renda (perfil constitucional e temas específicos). $3 \mathrm{a}$. ed. São Paulo: Malheiros, 2009. ps. 38 e ss.

${ }^{125}$ Cf. CARRAZZA, Roque Antônio. Imposto sobre a Renda (perfil constitucional e temas específicos). $3 \mathrm{a}$. ed. São Paulo: Malheiros, 2009. ps. 60 e 65.

${ }^{126}$ apud LEMKE, Gisele. Imposto de Renda - os Conceitos de Renda e de Disponibilidade Econômica e Jurídica. São Paulo: Dialética, 1998. p. 36.

${ }^{127}$ Cf. CARRAZZA, Roque Antonio. Imposto sobre a Renda (perfil constitucional e temas específicos). 3a. ed. São Paulo: Malheiros, 2009. ps. 68 e 69.
} 
atribui à generalidade o sentido de tratar todas as situações sob uma norma geral, sendo aplicável a todos os contribuintes e em contraposição à seletividade ${ }^{128}$; já a universalidade significaria a tributação sobre todo o patrimônio, sem qualquer fracionamento ${ }^{129}$.

Em relação a esses conteúdos semânticos conferidos pela doutrina, é bastante interessante a observação de Gisele Lemke, para quem os signos generalidade e universalidade têm idênticos significados na linguagem dos dicionários. A distinção perpetrada pela doutrina, então, seria, em seu entender, arbitrária; porém, tal arbitrariedade não mereceria censura, uma vez que (i) a distinção é necessária e imposta pela CF/88 e (ii) os significados alcançados pela doutrina são possíveis ${ }^{130}$.

É de se notar que - e aqui é o ponto que mais nos interessa para os fins colimados - tais critérios são convergentes com a acepção de base de renda, confirmandoo, portanto. Com efeito, Ricardo Mariz de Oliveira aduz que o critério da generalidade “(...) se amolda à própria natureza do imposto de renda, cujo substrato ínsito e necessário é existir acréscimo patrimonial, não havendo razões jurídicas válidas para distinguir um aumento de outro."131 Nesse mesmo sentido, continua o renomado doutrinador: “(...) princípio da universalidade é que ele se amolda à natureza pura do imposto de renda, incidente que é sobre acréscimo patrimonial."132

Roque Antonio Carrazza salienta que corolário do critério da universalidade entendido como a tributação global do conjunto de elementos integrantes do patrimônio - é a impossibilidade de o imposto de renda incidir exclusivamente na fonte, sem levar em conta a real existência, no ano-base, de acréscimo patrimonial ${ }^{133}$.

Portanto, parece-nos que a acepção de base (conceito jurídico preexistente à $\mathrm{CF} / 88$ ) de renda e proventos de qualquer natureza foi confirmada pela $\mathrm{CF} / 88$, razão pela qual adotar-se-á como premissa, no curso deste trabalho, a idéia de que o constituinte autorizou a União a instituir imposto de renda sobre o acréscimo de patrimônio dos

\footnotetext{
${ }^{128}$ Cf. OLIVEIRA, Ricardo Mariz de. Fundamentos do Imposto de Renda. São Paulo: Quartier Latin, 2008. p. 253.

${ }^{129}$ Cf. OLIVEIRA, Ricardo Mariz de. Fundamentos do Imposto de Renda. São Paulo: Quartier Latin, 2008. p. 255.

${ }^{130}$ Cf. LEMKE, Gisele. Imposto de Renda - os Conceitos de Renda e de Disponibilidade Econômica e Jurídica. São Paulo: Dialética, 1998. p. 37.

${ }^{131}$ OLIVEIRA, Ricardo Mariz de. Fundamentos do Imposto de Renda. São Paulo: Quartier Latin, 2008. p. 254.

132 OLIVEIRA, Ricardo Mariz de. Fundamentos do Imposto de Renda. São Paulo: Quartier Latin, 2008. p. 256.

${ }^{133}$ Cf. CARRAZZA, Roque Antonio. Imposto sobre a Renda (perfil constitucional e temas específicos). 3 a. ed. São Paulo: Malheiros, 2009. p. 45.
} 
contribuintes. Nada além dessa circunstância pode ser onerada pela União a esse título, sob pena de desequilibrar a forma federativa do Estado brasileiro.

De todo modo, mesmo descoberto o conteúdo da regra de competência tributária inserta no artigo 153 , III, da $\mathrm{CF} / 88$, não se pode deslembrar que o legislador ordinário, na instituição do imposto de renda (e, aliás, de qualquer outra exação), deve se ater a outras limitações constitucionais. Significa dizer, o legislador não poderá se valer de todo o campo de abrangência do conteúdo da regra de competência tributária lato sensu (ou, na dicção de Humberto Ávila, limitação decorrente de normas de competência beschränkung aus Kompetenzbestimmungem ${ }^{134}$ ); deverá observar, dentre outros, os limites substanciais ao exercício da competência (substantielle beschränkung) ${ }^{135}$.

Dito de outra maneira, a autorização constitucional para tributação da renda não está cingida à regra de competência lato sensu (artigo 153, III, da CF/88); decorre ela “(...) de uma conexão entre direitos fundamentais, princípios constitucionais fundamentais e gerais e regras de competência." ${ }^{136}$ Em poucas palavras, renda constitucionalmente tributável não tem relação apenas com seu conceito; tem relação com todas as limitações que o sistema impõe.

No capítulo seguinte, desenvolveremos melhor essa idéia, dando enfoque especial ao princípio da capacidade contributiva enquanto limitação substancial, vale dizer, limitação ao exercício da competência tributária lato sensu.

${ }^{134}$ Cf. ÁVILA, Humberto. Sistema Constitucional Tributário. 4.ed. São Paulo: Saraiva: 2010. p. 77.

${ }^{135}$ Cf. ÁVILA, Humberto. Sistema Constitucional Tributário. 4.ed. São Paulo: Saraiva: 2010. p. 77.

136 ÁVILA, Humberto. Sistema Constitucional Tributário. 4.ed. São Paulo: Saraiva: 2010. p. 379. 


\section{3. O PRINCÍPIO DA CAPACIDADE CONTRIBUTIVA: LIMITE PARA O EXERCÍCIO DA COMPETÊNCIA TRIBUTÁRIA}

\subsection{PRINCÍPIOS JURÍDICOS}

\subsubsection{ADVERTÊNCIA PRELIMINAR: O CONSEQUENTE NORMATIVO DOS PRINCÍPIOS JURÍDICOS}

De fundamental importância para nossas pretensões, particularmente para identificarmos a zona constitucionalmente autorizada para a tributação da renda, é apontar que os princípios jurídicos, no que tange a seu papel na aplicação do direito, vão além da mera recomendação dirigida ao legislador infraconstitucional, vale dizer, espécie normativa de conteúdo meramente programático ${ }^{137}$.

Nesse ponto, fazemos uso da excelente obra de Humberto Ávila sobre Teoria dos Princípios, na qual o autor, compendiando e sistematizando diversos entendimentos acerca dos princípios jurídicos, critica a idéia de que a distinção entre regras e princípios residiria na existência - apenas nas regras - de estrutura analítica composta por hipótese e consequente normativo. $\mathrm{O}$ autor, confirmando existir consequente normativo nos princípios jurídicos, esclarece que eles estipulam fins perseguidos, sem determinar, de antemão, quais os meios escolhidos. Nesse particular é que regras e princípios se distanciam, na medida em que há, nas primeiras, maior precisão quanto à definição do comportamento a ser seguido $^{138}$; já, nos princípios, sua concretização depende de um ato institucional de aplicação que deverá encontrar o comportamento necessário à promoção do fim ${ }^{139}$. Daí porque o renomado Professor gaúcho afirma que os princípios visam à manutenção de um estado ideal de coisas. São suas palavras:

\footnotetext{
137 Sobre crítica à doutrina que prega o caráter meramente programático dos princípios jurídicos, vide Alfredo Augusto Becker (Teoria Geral do Direito Tributário. 2. ed. São Paulo: Saraiva, 1972. p. 444.).

138 “(...) apesar de os princípios não possuírem um caráter frontalmente descritivo de comportamento, não se pode negar que sua interpretação pode, mesmo em nível abstrato, indicar as espécies de comportamentos a serem adotados, especialmente se for feita uma reconstrução dos casos mais importantes." (ÁVILA, Humberto. Teoria dos Princípios. Da definição à aplicação dos princípios jurídicos. 11.ed. São Paulo: Malheiros, 2010. p. 43.)

${ }^{139}$ Cf. ÁVILA, Humberto. Teoria dos Princípios. Da definição à aplicação dos princípios jurídicos. 11.ed. São Paulo: Malheiros, 2010. p. 80.
} 
“Os princípios instituem o dever de adotar comportamentos necessários à realização de um estado de coisas (...) Pode até haver incerteza quanto ao conteúdo do comportamento a ser adotado, mas não há quanto à sua espécie: $\mathrm{o}$ que for necessário para promover o fim é devido."140

Essas conclusões a respeito dos princípios jurídicos serão de extrema importância para os fins que colimamos. Isso porque, de plano, afasta a noção de serem os princípios jurídico-constitucionais meras normas dirigidas exclusivamente ao legislador infraconstitucional. Ademais, instiga-nos a identificar quais seriam as espécies de comportamentos pretendidos pelo constituinte ao juridicizar o princípio da capacidade contributiva e, via de consequência, se elas (as espécies) interferem, direta ou indiretamente, na definição da autorização constitucional para a tributação da renda. Precisamente, interessa-nos o princípio da capacidade contributiva no que diz respeito à sua função bloqueadora ${ }^{141}$, ou seja, função de afastar elementos expressamente previstos que sejam incompatíveis com o estado ideal de coisas a ser promovido.

\subsubsection{PRINCÍPIOS CONSTITUCIONAIS COMO LIMITADORES DO EXERCÍCIO DA COMPETÊNCIA TRIBUTÁRIA}

O titular da competência tributária lato sensu não poderá exercê-la em sua plenitude, ignorando haver na $\mathrm{CF} / 88$ as limitações ao próprio exercício dessa competência. Roque Antonio Carrazza, em seu festejado Curso de Direito Constitucional Tributário, aduz:

"Indaga-se, amiúde, se o legislador, ao exercitar a competência tributária, encontra limites jurídicos. Parece-nos induvidoso que sim. (...) Exemplificando, o tributo só será válido se for criado por meio de lei; se esta lei tiver sido editada de acordo com o processo legislativo (constitucionalmente traçado); se esta lei atender ao princípio da igualdade; (...)"142

Se assim é, a tributação da renda exige a análise de duas espécies de limitações à autorização constitucional para a tributação da renda. A primeira, analisada no capítulo

\footnotetext{
${ }^{140}$ Cf. ÁVILA, Humberto. Teoria dos Princípios. Da definição à aplicação dos princípios jurídicos. 11.ed. São Paulo: Malheiros, 2010. ps. 62 e 63.

${ }^{141}$ Cf. ÁVILA, Humberto. Teoria dos Princípios. Da definição à aplicação dos princípios jurídicos. 11.ed. São Paulo: Malheiros, 2010. p. 98.

${ }^{142}$ CARRAZZA, Roque Antônio. Curso de Direito Constitucional Tributário. 19. ed. São Paulo: Malheiros, 2004. p. 441.
} 
anterior, diz respeito à regra de competência lato $\operatorname{sensu}^{143}$ (artigo 153, III, da CF/88), apta a definir o que é e o que não é renda. A segunda, às demais limitações constitucionais ao poder de tributar (ou regras de competência stricto sensu ${ }^{144}$ ), nomeadamente o princípio da capacidade contributiva.

Nesse contexto, interessante é a observação de Andrei Pitten Velloso sobre a natureza da regra de competência lato sensu e sua relação com os princípios constitucional-tributários. Em suma, o jurista gaúcho tratou de analisar se elas (as regras de competência lato sensu) consubstanciar-se-iam em regras definitivas ou, por outro lado, em regras prima facie. A diferença fundamental entre essas duas espécies residiria na circunstância de que as primeiras não superáveis por razões em contrário, o que, para o estudo das regras de competência, é de fundamental importância. Afinal de contas, o caráter prima facie das regras viabilizaria a livre ponderação de princípios e argumentos e do recurso à justificação da regra, de maneira a restringir ou mesmo ampliar a regra de competência lato sensu. De todo modo, Andrei Pitten Velloso conclui serem as regras de competência lato sensu da espécie das regras definitivas, em função da elevada rigidez do sistema constitucional tributário ${ }^{145}$. Para o autor, as razões que pesam contra a criação de normas impositivas poderão limitar o exercício da competência, mas não a regra de competência em si, a qual é definitiva.

Com efeito, acreditamos que a relação entre as regras de competência lato sensu e as limitações ao poder de tributar poderia ser representada graficamente da seguinte maneira:

143 Para Humberto Ávila, limitação decorrente de normas de competência - beschränkung aus Kompetenzbestimmungem (Cf. Ávila. Humberto. Sistema Constitucional Tributário. 4.ed. São Paulo: Saraiva: 2010. p. 77.). Para Andrei Pitten Velloso, condições materiais da competência (Cf. VELLOSO, Andrei Pitten. Conceitos e competências tributárias. São Paulo: Dialética, 2005. p. 159).

${ }^{144}$ Para Humberto Ávila, limitações substanciais ao exercício da competência - substantielle beschränkung (Cf. Ávila. Humberto. Sistema Constitucional Tributário. 4.ed. São Paulo: Saraiva: 2010. p. 77.). Para Andrei Pitten Velloso, condições impostas ao exercício da competência tributária (Cf. VELLOSO, Andrei Pitten. Conceitos e competências tributárias. São Paulo: Dialética, 2005. p. 159).

${ }^{145}$ Cf. VELLOSO, Andrei Pitten. Conceitos e competências tributárias. São Paulo: Dialética, 2005. p. 161. 


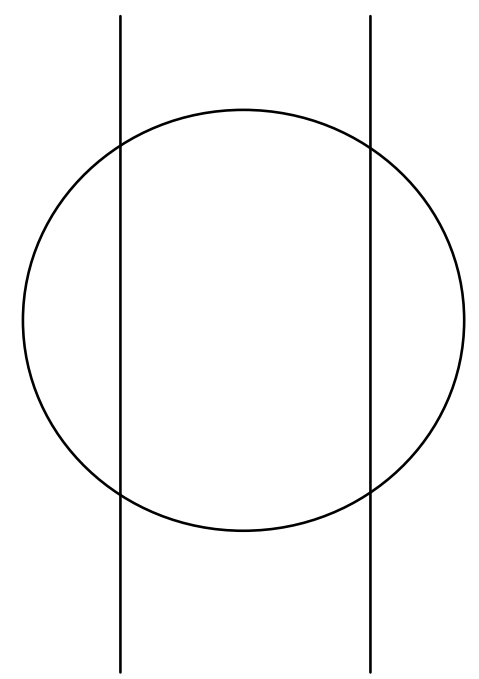

onde:

(i) o círculo representa a regra de competência lato sensu (conceito amplo de renda), a qual não poderá ser alargada pela apreciação valorativa dos princípios constitucionais;

(ii) a parte central do círculo, entre as duas linhas retas, representa a competência tributária stricto sensu, isto é, a competência lato sensu após o corte das limitações ao poder de tributar.

Essa representação é compatível com o pensamento de Luís César Souza de Queiroz expressado em sua obra sobre requisitos para uma tributação constitucional da renda. $\mathrm{O}$ autor, no mister de identificar tais requisitos, aponta três etapas. Numa delas expõe uma noção ampla de renda e proventos de qualquer natureza, compatível com a teoria da renda-acréscimo patrimonial. Adiante, sobre uma outra etapa, o Professor fluminense aduz:

"Essa definição preliminar e extremamente ampla construída serve somente de ponto de partida para a terceira e última etapa (...). Agora, será preciso combinar essa definição preliminar e extremamente ampla com os enunciados prescritivos da Constituição da República de 1988, a fim de construir (definir) o conceito amplo de 'renda e proventos de qualquer natureza' como base tributável, que represente o resultado da ponderação dos valores constitucionalmente positivados." 146

Fundados nessas premissas, abordaremos, neste capítulo, tais limitações ao poder de tributar, particularmente no que tange ao princípio da capacidade contributiva,

\footnotetext{
${ }^{146}$ QUEIROZ, Luís César Souza de. Imposto sobre a renda: requisitos para uma tributação constitucional. Rio de Janeiro: Forense, 2003. p. 230.
} 
particularmente no que diz respeito aos pontos imprescindíveis, a nosso ver, para cotejarmos a renda constitucionalmente tributável e o lucro contábil - nosso objetivo final.

\subsection{PRINCÍPIO DA CAPACIDADE CONTRIBUTIVA}

\subsubsection{BREVES CONSIDERAÇÕES SOBRE A CAUSA DOS IMPOSTOS, OS VALORES INSPIRADORES E A POSITIVAÇÃO DO PRINCÍPIO DA CAPACIDADE CONTRIBUTIVA NA CONSTITUIÇÃO BRASILEIRA}

Para apontarmos o estado ideal de coisas (ou função bloqueadora) pertinente ao princípio da capacidade contributiva, entendemos ser necessário, ainda que de maneira precária, discorrer sobre a origem, a causa e a justificativa deste mandamento. É o que faremos nas linhas a seguir.

Pois bem. Historicamente, do século XII até meados do século XVIII, a análise da causa na imposição tributária não se revelava frutífera e de grande interesse, na medida em que os tributos eram arrecadados com base na Razão do Estado e tinham a sua justificação na esporádica necessidade do detentor do Poder Absoluto ${ }^{147}$.

Em momento posterior, com a ascensão do liberalismo, é que começaram a surgir inúmeros estudos de grande valor relativamente à matéria. Deflagrou-se, então, a chamada Teoria do Benefício. Na visão de Montesquieu, já em 1748, o pagamento de impostos estaria ligado à fruição da riqueza sob a proteção do Estado ${ }^{148}$.

Numa evolução do tema, surgiram outros estudos ligando, de maneira mais incisiva, a fruição da riqueza sob a proteção do Estado à idéia de pagamento de tributos tendo em vista a capacidade econômica dos cidadãos. Nesse sentido, a clássica, porém atualíssima, obra do escocês Adam Smith, sobre a natureza e as causas da riqueza das nações, contemplava a noção de que os membros da coletividade deveriam contribuir com

\footnotetext{
${ }^{147}$ Cf. TORRES, Ricardo Lobo. Tratado de Direito Constitucional Financeiro e Tributário. Valores e Princípios Constitucionais Tributários. Vol. II. Rio de Janeiro, Editora Renovar: 2005. p. 288.

${ }^{148}$ Cf. DODGE, Joseph M. Theories of Tax Justice: Ruminations on the Benefit, Partnership, and Ability-topay Principles. N.Y.U. Tax Law Review. p. 402.
} 
as despesas do Estado de maneira proporcional às suas possibilidades, tendo por justificativa a proteção fornecida por este àqueles ${ }^{149}$.

Denota-se, desde esse momento, que a justificação da tributação confundia-se com a idéia que hoje se tem do princípio da capacidade contributiva. Assim, os adeptos da Teoria do Benefício chegam a afirmar que a capacidade econômica e o êxito patrimonial dos membros de cada coletividade se devem à atuação do Estado, ainda que essa atuação não se dê de maneira direta ao contribuinte; a tributação seria contraprestação pelo sucesso econômico dos cidadãos, somente obtido pela mediata ou imediata atuação do Estado junto à coletividade. Por assim ser, nada mais coerente que, como medida de justiça, impor exações à medida da capacidade econômica do contribuinte, favorecido como membro da coletividade protegida pelo Estado.

De outro lado, em oposição à Teoria do Benefício, houve a Teoria da Equivalência, segundo a qual somente pagaria o tributo aquele que gozasse de uma prestação estatal e o tributo seria pago de acordo com o grau de prestação ${ }^{150}$. Todavia, a idéia central dessa teoria não escapou de críticas. Como bem lembrou Luís Eduardo Schoueri, "com relação aos tributos não vinculados, a teoria da equivalência via-se diante do dilema de como explicar que não houvesse uma correlação entre o montante pago a título de tributos e a contraprestação dada aos contribuintes." ${ }^{151}$ Embora seja relevante no que diz respeito à contribuição ao estudo dos tributos vinculados, a Teoria da Equivalência mostra-se inadequada no que tange aos impostos ${ }^{152}$, afastando-se demasiadamente das idéias que fundamentam o princípio da capacidade contributiva.

Diante dessa constatação, não faltou, no âmbito da ciência jurídica, quem advogasse pela ausência de causa na instituição dos impostos. Isso porque, se, para os tributos vinculados, a Teoria da Equivalência gozaria de ampla aceitação e de indiscutível aplicação, os impostos não teriam causa, eis que não caracterizados como tributo contraprestacional. Sua instituição, em verdade, poderia ser justificada pelo poder de império do Estado, ao qual os cidadãos devem obediência. Assim, existiriam os tributos causais (tributos contraprestacionais) e não causais (impostos, de modo geral).

\footnotetext{
${ }^{149}$ Cf. SMITH, Adam. Riqueza das Nações: uma investigação sobre a natureza e as causas da riqueza das nações; tradução Getulio Schanoski Jr. São Paulo: Madras, 2009. p. 639.

${ }^{150}$ Cf. SCHOUERI, Luís Eduardo. Normas tributárias indutoras e intervenção econômica. Rio de Janeiro: Forense, 2005. p. 144.

${ }^{151}$ SCHOUERI, Luís Eduardo. Normas tributárias indutoras e intervenção econômica. Rio de Janeiro: Forense, 2005. p. 144.

${ }^{152}$ Vale lembrar que os impostos se destinam à arrecadação de recursos para as despesas gerais do Estado, voltando-se, em última análise, às prestações de serviços públicos indivisíveis, comuns a todos os membros da coletividade.
} 
Segundo seu maior expoente, o Professor da Universidade de Berna, Ernst Blumenstein, causa existe apenas em certos preços e tributos (taxas, contribuições de melhoria, impostos "sub-rogatórios") estatuídos sob o princípio da equivalência. Aos impostos, em cuja aplicação não há o mínimo traço de contraprestações ao contribuinte, repugna o conceito privatista de causa ${ }^{153}$.

Tal tese representou, em realidade, uma resposta à chamada versão causualista da Teoria do Benefício ${ }^{154}$, cujo maior expoente foi Benvenuto Grizzioti, liderando a chamada Escola de Pavia. Com efeito, o mestre italiano, embora em suas primeiras obras tenha defendido a Teoria da Equivalência, merecendo críticas em relação aos tributos não vinculados, como já salientado acima, passou a manifestar entendimento segundo o qual os impostos seriam a contribuição exigida dos cidadãos, pelo poder público, para lograr fins coletivos indistintamente, depreendendo-se que à prestação coletiva da sociedade corresponderia a uma contraprestação do Estado à sociedade, sendo tal serviço a causa primeira do imposto ${ }^{155}$.

Sendo inviável medir a importância das prestações do Estado para cada cidadão e, ainda, não podendo medir quanto o Estado gastou em benefício de cada contribuinte, a repartição coletiva se faz com fulcro na riqueza de cada qual. Por isso, Benvenuto Grizzioti afirma ser a capacidade contributiva a causa última do dever de pagar impostos $^{156}$. São do mestre italiano as seguintes palavras, as quais denotam uma espécie de círculo lógico entre a instituição de impostos e o dever de contribuir com as despesas do Estado com base na capacidade contributiva: "A despesa pública satisfaz os fins do Estado e promove os serviços públicos; estes incrementam imediatamente ou a longo prazo a capacidade contributiva; a capacidade contributiva dá lugar à cobrança do imposto; o imposto alimenta a despesa pública." 157

É esse círculo lógico que justifica, inclusive, a tributação de indivíduos que não tenham qualquer relação de nacionalidade ou residência com um dado Estado, desde que o

${ }^{153}$ Cf. BALEEIRO, Aliomar. Limitações Constitucionais ao Poder de Tributar. Notas de atualização de Misabel Abreu Machado Derzi. $7^{\mathrm{a}}$ edição. Rio de Janeiro: Editora Forense, 1998. p. 731.

${ }^{154}$ Sobre a versão causualista, ver TORRES, Ricardo Lobo. Tratado de Direito Constitucional Financeiro e Tributário. Valores e Princípios Constitucionais Tributários. Vol. II. Rio de Janeiro, Editora Renovar: 2005. p. 295.

${ }^{155}$ Cf. SCHOUERI, Luís Eduardo. Normas tributárias indutoras e intervenção econômica. Rio de Janeiro: Forense, 2005. p. 146.

${ }^{156}$ Cf. SCHOUERI, Luís Eduardo Normas tributárias indutoras e intervenção econômica. Rio de Janeiro: Forense, 2005. p. 146.

157 apud TORRES, Ricardo Lobo. Tratado de Direito Constitucional Financeiro e Tributário. Valores e Princípios Constitucionais Tributários. Vol. II. Rio de Janeiro, Editora Renovar: 2005. p. 298. 
tal indivíduo, de alguma maneira, se sujeite à ação dele (e, via de consequência, exista benefício econômico ao estrangeiro não residente) ${ }^{158}$.

Destaca-se, ainda, a chamada Teoria do Sacrifício, inaugurada por Rousseau e amplamente difundida por Stuart Mill e que ficou conhecida como teoria da utilidade marginal do capital. Segundo ela, o capital, além de determinado limite, apresenta menor utilidade social para o seu detentor e, por isso, uma tributação mais pesada (progressiva) seria perfeitamente justificável, pois implicaria equivalência de sacrifícios (ou sacrifício equimarginal) ${ }^{159}$.

Advogou-se a tese segundo a qual a arrecadação dos impostos - dadas as necessidades financeiras do Estado - deve ser realizada de maneira que cada contribuinte sacrifique uma quantidade igual de utilidade. Portanto, somente haveria igualdade na tributação "when apportioning the contribution of each person toward the expenses of the government so that he shall feel neither more nor less inconvenience from his share of the payment than every other person experiences from it.",160

A Teoria do Sacrifício tem o mérito de não se afastar do princípio da capacidade contributiva como veículo para justiça fiscal e, também, como seu fundamento $^{161}$.

Todavia, houve quem criticasse a idéia de sacrifício, justificando que, em realidade, os tributos indicam a participação nos custos da existência social (e não sacrifício). Assim, ganha relevância a noção de solidariedade. Para o Professor Luís Eduardo Schoueri, "a solidariedade se concretiza quando todos participam dos custos da existência social, na medida de sua capacidade." 162

Vê-se - dessa sumária exposição sobre as teorias que tentam adequar a imposição tributária à justiça fiscal - que é amplamente aceitável a noção de que o êxito

\footnotetext{
${ }^{158}$ Nesse sentido, BALEEIRO, Aliomar. Uma Introdução à Ciência das Finanças. 16 $6^{\mathrm{a}}$ ed. rev. e atualizada por Dejalma de Campos. Rio de Janeiro, Forense, 2002. p. 270.

${ }_{159}$ Cf. POLIZELLI, Victor Borges. Progressividade: Distribuição de Renda e Indução. In: Revista Direito Tributário Atual $\mathrm{n}^{\circ}$ 21. BONILHA, Paulo Celso Bergostrom; COSTA, Alcides Jorge; SCHOUERI, Luís Eduardo (coords). São Paulo: Dialética, 2007. 365 e 366.

${ }^{160}$ MILL, Stuart apud UCKMAR, Victor. Princípios Comuns de Direito Constitucional Tributário. Tradução de Marco Aurélio Greco. $2^{a}$ edição. São Paulo: Editora Malheiros, 1999. p. 91.

161 "Mas é sem dúvida a teoria do sacrifício a que mais vem se prestando a fundamentar a capacidade contributiva. Esta teoria tem um apelo intuitivo que afasta as capitações e os tributos fixos, pois neles resta claro que aqueles que possuem maior riqueza e patrimônio sofrem um sacrifício muito menor do que aqueles que possuem menos renda ou patrimônio. A teoria do sacrifício aponta então para o critério da capacidade contributiva e diz: por aí se implementa a igualdade, pois todos pagam suportando o mesmo ônus, o mesmo sacrifício.”(GODOI, Marciano Seabra de. Justiça, Igualdade e Direito Tributário. São Paulo: Dialética, 1999. p. 190.)

${ }^{162}$ SCHOUERI, Luís Eduardo. Normas tributárias indutoras e intervenção econômica. Rio de Janeiro: Forense, 2005.. p. 151.
} 
econômico dos cidadãos é instrumento indispensável na repartição dos gastos estatais indivisíveis entre os indivíduos da coletividade. Seja fundamentados na Teoria do Benefício, seja na Teoria do Sacrifício ou, por fim, na solidariedade, a idéia de repartição das despesas baseada na capacidade econômica dos cidadãos está, invariavelmente, presente, constituindo medida que se impõe para alcance da justiça tributária.

A propósito, não nos parece serem todas essas teorias irremediavelmente inconciliáveis, sendo possível, como fez recentemente Paul Kirchhof, combinar elementos da Teoria do Benefício e da Teoria do Sacrifício ${ }^{163}$ e concluir que, se é verdade que o Estado necessita de recursos para se organizar em proveito da coletividade (daí a causa para instituição dos impostos, devendo os membros da sociedade se sacrificarem para reunião desses recursos), não menos verídico é o fato de que o êxito na iniciativa privada, ao lado do esforço pessoal, deve-se também à atuação do Estado (na manutenção do mercado, v.g.).

Destarte, se o imposto é a espécie de tributo que, por excelência, tem a função de angariar recursos para as despesas gerais e indivisíveis do Estado, cuja atuação (manutenção do mercado, proteção da propriedade, etc.) aumentará e, até mesmo podemos dizer, viabilizará o progresso econômico dos particulares, nada mais coerente do que retirar dos contribuintes, via instituição de impostos, parcela de seu patrimônio baseado no seu êxito econômico, sendo essa noção elemento indispensável na caracterização dessa espécie tributária.

Alicerçados por essas premissas é que julgamos pertinentes as lições de Aliomar Baleeiro que, fornecendo sua concepção de imposto, pontifica sua íntima e inevitável relação com o princípio da capacidade contributiva:

"Entende-se por impostos a prestação de dinheiro que, para fins de interesse coletivo, uma pessoa jurídica de Direito público, por lei, exige coativamente de quanto lhe estão sujeitos e têm capacidade contributiva, sem que lhes assegure qualquer vantagem ou serviço específico em retribuição desse pagamento.”164

Coerente com essa noção de justiça fiscal no que diz respeito aos gastos gerais e indivisíveis do Estado (suportados pelos impostos), o legislador constituinte, ao disciplinar o regime jurídico dos impostos, determinou expressamente que:

\footnotetext{
${ }^{163}$ Cf. SCHOUERI, Luís Eduardo. Normas tributárias indutoras e intervenção econômica. Rio de Janeiro: Forense, 2005. p. 152 e 153.

${ }^{164}$ BALEEIRO, Aliomar. Uma Introdução à Ciência das Finanças. 16a ed. rev. e atualizada por Dejalma de Campos. Rio de Janeiro, Forense, 2002. p. 269.
} 
“Art. 145. (...)

$\S 1^{\text {o }}$. Sempre que possível, os impostos terão caráter pessoal e serão graduados segundo a capacidade econômica do contribuinte, facultado à administração tributária, especialmente para conferir efetividade a esses objetivos, identificar, respeitados os direitos individuais e nos termos da lei, o patrimônio, os rendimentos e as atividades econômicas do contribuinte."

Disso, e de tudo o que foi até aqui exposto, deriva que não pode ser admitida a instituição de impostos per capta ${ }^{165}$, baseados no princípio da equivalência ou cujo fato gerador seja algo que não expresse manifestação de riqueza. Todos esses meios são inaptos para assegurar a justa distribuição das despesas gerais do Estado, isto é, divisão das despesas com base no êxito econômico dos cidadãos.

\subsubsection{O ESTADO IDEAL DE COISAS A SER PRESERVADO PELO PRINCÍPIO DA CAPACIDADE CONTRIBUTIVA: A TRIBUTAÇÃO DO PATRIMÔNIO}

A exposição acima nos conforta para afirmar que a função bloqueadora do princípio da capacidade contributiva (ou uma delas, melhor dizendo) reside na circunstância de o Estado estar proibido de instituir impostos cujo aspecto material é alheio à noção de êxito econômico alcançado pelo cidadão. Trata-se, em expressão consagrada pela doutrina pátria e alienígena, de capacidade contributiva objetiva (ou absoluta).

A afirmação acima, embora represente um importante norte, ainda contém algum grau de indeterminabilidade, eis que não indicado precisamente o índice para avaliar em quais situações o aspecto material do imposto alberga, ou não, referido êxito econômico.

Antes de indicarmos esse índice, devemos sublinhar aqui que, quando se fala em êxito econômico alcançado pelo cidadão, tal noção deve estar associada ao êxito presente (e não futuro). Nos dizeres de Humberto Ávila, “(...) o imposto alcança a

\footnotetext{
${ }^{165}$ Neste particular, Klaus Tipke: "Como alternativas para o princípio da capacidade contributiva destacamse especialmente o princípio do imposto per capta e o princípio da equivalência. Um imposto uniforme por cabeça, igualitário, que nivela beneficiários de auxílio social, pensionistas, estudantes e milionários da renda nega todo elemento dferencial, ofende a proibição do arbítrio (....); ele é totalmente alheio ao pensamento de justiça geralmente dominante (....)." (TIPKE, Klaus, LANG, Joaquim; (colaboradores) Romam Seer ... (et. al.) Direito Tributário (Steuerrecht). Vol. I. Tradução da $18^{a}$ edição alemã, totalmente refeita, de Luiz Dória Furquim. Porto Alegre: Sergio Antonio Fabris Ed., 2008. p. 204.)
} 
capacidade contributiva presente, não a capacidade contributiva futura."166 Tributar a capacidade contributiva futura representaria atuar contrariamente ao estado ideal de coisas a ser preservado pelo próprio princípio da capacidade contributiva. Não há espaço, assim, para tributação de meras expectativas de êxito, as quais não são suficientes para justificar a contribuição do cidadão para com as despesas gerais do Estado.

Feita essa importante ressalva, podemos asseverar que o índice para aferir o êxito econômico alcançado (até o presente, com o perdão da redundância) é o patrimônio, em sua acepção estritamente jurídica (adiante melhor explorada).

Não somos os primeiros a apontar esse índice. O Professor Roberto Quiroga Mosquera doutrina: “(...) o patrimônio das pessoas é fonte reveladora de riqueza. Nessa fonte é que o Estado irá buscar os recursos suficientes para satisfazer a necessidade da coletividade." 167 Nesse mesmo sentido, coloca-se Ricardo Lacaz Martins, em recente tese de doutoramento apresentada à Faculdade de Direito da Universidade de São Paulo: "A tributação em geral recai necessariamente sobre o patrimônio do contribuinte, seja pela exteriorização da sua propriedade, seja pelo acréscimo de patrimônio." ${ }^{168}$ Para Renato Renck, “(...) o mínimo a extrair é que a relação jurídico-tributária está condicionada à ocorrência efetiva e definitiva do evento econômico que implica ganho de uma nova parcela de patrimônio.",169

O patrimônio, enquanto índice para aferir o êxito econômico dos cidadãos, torna possível a tributação sobre o êxito alcançado até o presente, excluindo meras expectativas de êxito econômico futuro. $\mathrm{O}$ estado ideal de coisas a ser preservado, por meio do princípio da capacidade contributiva, consiste na proibição de o Estado tributar algo além da riqueza ou êxito econômico alcançado, assim entendido o patrimônio do cidadão. Assim, os sujeitos passivos contribuirão apenas com aquilo que já conquistaram (i.e., contribuirão com aquilo que já integra seu patrimônio) e não meras expectativas de conquistas, de algo que apenas está no "patrimônio econômico" do cidadão ${ }^{170}$. Portanto, o que se tributa é o patrimônio conquistado até o presente. Retirar (tributar) algo que está além do patrimônio atinge o estado ideal de coisas a ser mantido pelo princípio da

${ }^{166}$ Cf. ÁVILA, Humberto. Sistema Constitucional Tributário. 4.ed. São Paulo: Saraiva: 2010. p. 376.

${ }^{167}$ MOSQUERA, Roberto Quiroga. O Conceito Constitucional de Renda e Proventos de Qualquer Natureza. Dissertação. Mestrado. Pontifícia Universidade Católica de São Paulo, 1996. p. 103.

${ }^{168}$ MARTINS, Ricardo Lacaz. A Tributação da Renda Imobiliária. Tese. Doutorado. Universidade de São Paulo, 2009. p. 65.

${ }_{169}$ RENCK, Renato Romeu. Imposto de renda da pessoa jurídica: critérios constitucionais de apuração da base de cálculo: uma proposta de interpretação sistemática do Direito. Porto Alegre: Livraria do Advogado, 2001. p. 164.

170 Essa noção de "patrimônio econômico" será melhor trabalhada quando tratarmos da representação contábil do patrimônio. 
capacidade contributiva. Não haveria aquilo que a doutrina denomina de capacidade contributiva objetiva.

Sobre a íntima relação entre o patrimônio e o princípio da capacidade contributiva objetiva, Luís César Souza de Queiroz ensina:

"O Princípio da Capacidade Contributiva Objetiva, que caracteriza a espécie tributária imposto, demanda que o conceito 'renda e proventos de qualquer natureza' seja um 'sinal de riqueza pessoal'. Como se disse, o conceito 'riqueza' tem relação com os direitos subjetivos e deveres jurídicos avaliáveis em moeda que um ou mais sujeitos de direito são titulares em dado instante ou que adquirem em certo período."

Podemos afirmar, assim, que a tributação compatível com a capacidade contributiva se concretiza única e exclusivamente tendo por fundamento o patrimônio, seja em suas dimensões dinâmica ou estática. Nesse sentido, podemos apresentar a seguinte representação gráfica, inspirados em Klaus Tipke, Joaquim Lang e et. al. ${ }^{172}$ :

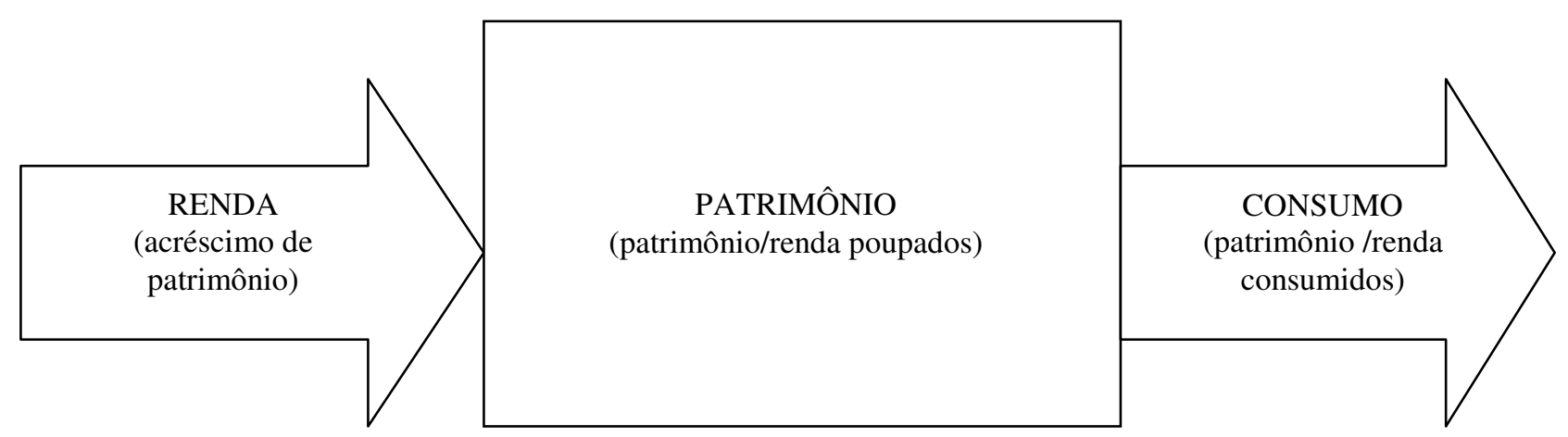

Onde:

(i) a renda (representada pela primeira flecha) nada mais é do que o patrimônio em seu sentido dinâmico ${ }^{173}$, ou seja, a circunstância de ter o patrimônio acrescido num determinado lapso temporal - o ingresso de patrimônio;

(ii) o patrimônio stricto sensu (representado pela figura retangular) é o resultado do acúmulo de renda (renda poupada) ao longo dos tempos e é, a despeito de

${ }^{171}$ QUEIROZ, Luís César Souza de. Imposto sobre a renda: requisitos para uma tributação constitucional. Rio de Janeiro: Forense, 2003. p. 235.

172 TIPKE, Klaus, LANG, Joaquim; (colaboradores) Romam Seer ... (et. al.) Direito Tributário (Steuerrecht). Vol. I. Tradução da $18^{a}$ edição alemã, totalmente refeita, de Luiz Dória Furquim. Porto Alegre: Sergio Antonio Fabris Ed., 2008. p. 210.

${ }^{173}$ Nesse sentido, MOSQUERA, Roberto Quiroga. O Conceito Constitucional de Renda e Proventos de Qualquer Natureza. Dissertação. Mestrado. Pontifícia Universidade Católica de São Paulo, 1996. p. 109 e ss. 
seus inconvenientes, comumente utilizado como índice para tributação, como mostram os exemplos dos tradicionais IPTU, IPVA, etc ${ }^{174}$;

(iii) os impostos sobre consumo representam legítima manifestação de riqueza e índice para tributação, eis que incidentes sobre a parcela do patrimônio/renda consumido - a renda consumida.

Portanto, é de se notar que o êxito econômico dos cidadãos está sempre intimamente ligado ao patrimônio, o qual deverá servir como índice para a tributação, sob pena de mitigar o princípio da capacidade contributiva. Daí porque ser de feliz lembrança a expressão consagrada por Alfredo Augusto Becker: fatos-signos presuntivos de renda ou capital $^{175}$.

Para que se compreenda o patrimônio enquanto índice para identificação do êxito econômico alcançado, nada melhor do que explorá-lo em seus aspectos fundamentais. É o que faremos no item seguinte.

\subsubsection{BREVES CONSIDERAÇÕES SOBRE O PATRIMÔNIO}

Não há como compreender o patrimônio - ao menos quando se pretenda fazê-lo com o rigor científico que o instituto demanda - sem antes revisitar algumas das noções elementares da fenomenologia jurídica. A propósito, a própria concepção do Direito, como instituição indissociável e intimamente ligada à convivência social (não nos esqueçamos do velho, porém, indispensável brocardo ubi societas ubi jus), exige a exata compreensão da origem e do conteúdo das relações entre os sujeitos de direito e, enfim, do patrimônio.

Pois bem. Conferindo à bilateralidade atributiva o caráter de elemento essencial na captação do sentido do Direito, Miguel Reale inicia suas lições sobre o tema aduzindo que "a conduta jurídica, ao contrário [da moral], não pertence exclusivamente ao indivíduo como sujeito universal, pois somente é jurídica porque e na medida em que se proporciona a outrem."176 Destaca o renomado jusfilósofo que no mundo da moral,

\footnotetext{
174 “Tipke entende que o imposto sobre a propriedade é apenas um sinal de capacidade contributiva e não denota efetiva capacidade de seu proprietário; os impostos sobre o patrimônio, como defende, devem recair sobre a renda produzida por eles, posição bastante racional e acertada. Esse tipo de tributo, se utilizado em países em desenvolvimento, gera um efeito contrário do pretendido (distribuição de riqueza), pois desestimula a poupança e estimula a evasão de divisas.” (ZILVETI, Fernando Aurélio. O Princípio da Realização da Renda. In: Luís Eduardo Schoueri (coord.). Direito Tributário - Homenagem a Alcides Jorge Costa. vol. I. São Paulo: Quartier Latin, 2003. p. 307.)

${ }^{175}$ BECKER, Alfredo Augusto. Teoria Geral do Direito Tributário. 2. ed. São Paulo: Saraiva, 1972. p. 453.

${ }^{176}$ REALE, Miguel. Filosofia do Direito. 10.ed. São Paulo: Saraiva, 1983. p. 685.
} 
inversamente, ocorre a “(...) adesão espontânea do obrigado, que só assim poderá ser fiel a si mesmo (...)."177

Partindo-se, primeiramente, da noção de bilateralidade do fenômeno jurídico, é que se diz que, para pertencer ao mundo do Direito, para ser jurídico, há necessariamente que haver, no mínimo, dois sujeitos de direito; sem relação que una dois ou mais sujeitos, não há que se cogitar em fenômeno jurídico. Para Savigny, inaugurando o conceito de relação jurídica, "cada relação de direito nos aparece como relação entre pessoa e pessoa, determinada por uma regra e direito (...)." ${ }^{178}$ Não mais se concebe - que isso fique bem claro - é a existência de uma relação jurídica fora desse padrão, como a pretensamente estabelecida entre uma pessoa e uma coisa, circunstância inviável ainda que se trate de direitos reais. Essa lição é tão fundamental na compreensão da fenomenologia jurídica que mereceu a seguinte advertência de Pontes de Miranda: “Quando H. Dernburg (...) definiu a relação jurídica como relação juridicamente eficaz entre pessoa e pessoa, ou entre pessoa e coisa, desatendendo a que a relação jurídica é social, cometeu um dos maiores erros em teoria geral do direito." 179

Além de invariavelmente bilateral, não se pode deslembrar o caráter de atributividade no Direito, marcando, em mais esse aspecto, sua distinção da conduta moral. Enquanto nessa (a moral) o sujeito não pode ser compelido coercitivamente a seguir o comportamento desejado, naquela (experiência jurídica) há o sentido de exigibilidade, havendo, como consequência última, execução forçada. Daí afirmar que originam da atributividade a exigibilidade e, por fim, a coercibilidade no cumprimento do objeto da relação jurídica.

Não nos esqueçamos, porém, que somente há que cogitar em bilateralidade atributiva (e em relação jurídica, portanto) se, antes, o vínculo corresponder a uma hipótese normativa. $\mathrm{Ou}$, melhor dizendo, verificada a ocorrência no mundo social de subsunção do fato à hipótese normativa, desde que devidamente formalizada por linguagem competente, exsurgirá a relação jurídica, sempre envolvendo um sujeito ativo, titular do direito subjetivo, e um sujeito passivo, cometido do dever de cumpri-la. Melhor explicando, Paulo de Barros Carvalho doutrina que "quando se diz que, ocorrido o fato, nasce a relação

\footnotetext{
${ }^{177}$ REALE, Miguel. Filosofia do Direito. 10.ed. São Paulo: Saraiva, 1983. p. 685.

178 apud RÁO, Vicente. O Direito e a Vida dos Direitos. Vol. I, Tomo II. 2.ed. São Paulo: Ed. Resenha Universitária, 1976. p. 166.

${ }^{179}$ MIRANDA, Pontes. Tratado de Direito Privado. Tomo II. 4.ed. São Paulo: Ed. Revista dos Tribunais, 1983. p. 4.
} 
jurídica, estamos lidando com o acontecimento de dois fatos: do fato-causa (fato jurídico) e do fato-efeito (relação jurídica)" ${ }^{\prime 180}$.

Seja como for, infere-se que a bilateralidade atributiva é característica marcante das relações jurídicas (e do próprio Direito), com a qual elas se destacam das demais formas de relacionamento social. Dentre os inúmeros laços que vinculam o relacionamento humano, apenas podem ser considerados jurídicos aqueles que apresentam a bilateralidade atributiva como qualidade. Analiticamente falando, a relação jurídica pode ser reduzida aos seguintes elementos: (i) um sujeito ativo, (ii) um sujeito passivo, (iii) o vínculo de atributividade segundo a ordem jurídica estabelecida e (iv) um objeto ${ }^{181}$.

É nesse contexto que se insere o patrimônio. Embora esse signo - assim como a maioria - não escape de vícios e confusões inerentes à linguagem, como a vaguidade ${ }^{182}$, para fins da fenomenologia jurídica, deve ser tomado como conjunto ou universalidade de relações jurídicas de um sujeito de direito, sejam aquelas em que esse sujeito figure no polo ativo ou noutras em que ele aparece no polo passivo ${ }^{183}$.

Não interessa para o direito e, portanto, à compreensão daquilo que se deva entender por patrimônio quaisquer outros tipos de relações sociais que não aquelas de natureza estritamente jurídicas, nelas embutidas a já mencionada bilateralidade atributiva. Não há espaço no patrimônio para outras relações sociais que não as jurídicas. Para Ricardo Mariz de Oliveira, "é, portanto, o direito, e nada mais do que ele, que suporta a constituição de um patrimônio pessoal, e, por isso, é somente nele que devemos buscar a intelecção do seu conceito, do seu conteúdo e dos seus limites." 184

O patrimônio, dessa forma, é unitário e indivisível. Pode-se dizer que cada sujeito é dotado de um único patrimônio, ainda que parte de suas relações esteja gravada a um fim específico, como ocorre na afetação. Nesse sentido, socorremo-nos de Caio Mário da Silva Pereira, para quem: “A afetação, porém, implicará composição de um patrimônio se se verificar a criação de uma personalidade, como se dá com as fundações. Caso

\footnotetext{
${ }^{180}$ CARVALHO, Paulo de Barros. Direito Tributário: fundamentos jurídicos da incidência. 3.ed. São Paulo: Saraiva, 2004. p. 134.

${ }^{181}$ REALE, Miguel. Lições Preliminares de Direito. 24.ed. São Paulo: Saraiva, 1998. p. 217-218.

182 "A vaguidade é o estado de indeterminação da palavra, é sua condição de imprecisão." (MOUSSALLEM, Tárek Moyses, Fontes no direito tributário. 2.ed. São Paulo: Noeses, 2006. p. 34.)

${ }^{183}$ Nesse sentido, dentre outros: GOMES, Orlando. Introdução ao Direito Civil. 19.ed. Rio de Janeiro: Forense, 2007. p. 182; PEREIRA, Caio Mário da Silva. Instituições de Direito Civil. 20.ed. vol. I. Rio de Janeiro: Forense, 2004. p. 391; BRITO, Edvaldo. O excesso de retirada tributável como acréscimo patrimonial. In: MARTINS, Ives Gandra da Silva (Coord.). Imposto de Renda: conceitos, princípios, comentários. 2.ed. São Paulo: Atlas, 1996. p. 115

${ }^{184}$ OLIVEIRA, Ricardo Mariz de. Fundamentos do Imposto de Renda. São Paulo: Quartier Latin, 2008. p. 50 .
} 
contrário, eles se prendem ao fim, porém continuam encravados no patrimônio do sujeito." 185

Abre-se aqui um parêntese para ressalvar que as meras expectativas de direito e de dever não integram o patrimônio. A ordem jurídica não confere a elas a atributividade de que falamos acima; não há contra quem reclamar quaisquer direitos subjetivos se pendentes condições suspensivas aludidas no artigo 125 do Código Civil ${ }^{186}$. Nessas circunstâncias, inexiste direito adquirido, conceito diametralmente oposto à expectativa de direito. Fecha-se parêntese.

Ainda nessa sumária abordagem do patrimônio, acreditamos ser importante apontar que, tendo em vista os objetivos de nosso estudo, por óbvio, interessam-nos apenas os direitos e deveres apreciáveis monetariamente, o que exclui uma série de outras relações jurídicas. A propósito, a doutrina contemporânea tem afirmado que somente cabe na noção de patrimônio o complexo de direitos e deveres que tenha tal característica, excluindo, por conseguinte, outros tantos de natureza pessoal ou de família. Daí porque referir-se a direitos patrimoniais e extra-patrimoniais.

Por fim, é importante que se diga que essa acepção de patrimônio não é manipulável pelo legislador. Trata-se, em nosso entender, de uma entidade lógica, assim como outros tantos institutos jurídicos ${ }^{187}$, próprios da Teoria Geral do Direito e inerentes à compreensão da fenomenologia do direito.

Por ser assim, não nos parece procedente a afirmação de Luís Eduardo Schoueri de não haver indícios de que o direito tributário teria albergado a acepção civilista do termo; em seu lugar, poderia ter empregado a noção de patrimônio advinda da LSA, por exemplo $^{188}$. Como dissemos, não se trata de mera acepção consagrada pelo Direito Civil, mas sim uma entidade lógica e própria de Teoria Geral do Direito, não manipulável pelo legislador. Ademais, a noção de patrimônio contida na LSA é por demais específica e visa a atender seus propósitos especiais. Tal noção será, no curso do presente trabalho, melhor

\footnotetext{
${ }^{185}$ PEREIRA, Caio Mário da Silva. Instituições de Direito Civil. 20.ed. vol. I. Rio de Janeiro: Forense, 2004. p. 400.

186 “Art. 125. Subordinando-se a eficácia do negócio jurídico à condição suspensiva, enquanto esta se não verificar, não se terá adquirido o direito, a que ele visa." (grifos nossos)

${ }^{187}$ Sobre a relação jurídica, Paulo de Barros Carvalho nos ensina: “A relação jurídica, antes de ser jurídica, é relação. E, como tal, permanece inteiramente subordinada às diretrizes da Lógica, mais precisamente, da Lógica dos Predicados Poliádios ou Lógica das Relações." (CARVALHO, Paulo de Barros. Direito Tributário: Fundamentos Jurídicos de Incidência. 3. ed. São Paulo: Saraiva, 2004. p. 145.)

${ }^{188}$ Cf. SCHOUERI, Luís Eduardo. O mito do Lucro Real na Passagem da Disponibilidade Jurídica para a Disponibilidade Econômica. In: MOSQUERA, Roberto Quiroga. LOPES, Alexsandro Broedel (coords.). Controvérsias Jurídico-Contábeis (aproximações e distanciamentos). São Paulo, Dialética, 2010. p. 250.
} 
analisada para que seja possível a avaliação quanto à sua adequação, ou não, ao direito tributário.

As ponderações acima sobre o patrimônio já são suficientes para os fins que colimamos em nossa empreitada e servirão de base para algumas das tomadas de posições adiante explicitadas.

\subsubsection{A INTERPRETAÇÃO POSSÍVEL DE DISPONIBILIDADE ECONÔMICA DE RENDA}

Detectamos alhures ser o patrimônio fonte e limite intransponível para o regime dos impostos, sob pena de contrariar o estado ideal de coisas a ser preservado pelo princípio da capacidade contributiva. Por ser assim, chama-nos atenção a redação do artigo 43 do CTN, a qual faz alusão à disponibilidade econômica ou jurídica de renda $e$ proventos de qualquer natureza. Afinal de contas, o que podemos entender por disponibilidade econômica de renda?

A esse respeito, Brandão Machado, em alentado estudo sobre o tema, menciona aquilo que a doutrina alemã denominava de propriedade econômica. Segundo o artigo 80 do anteprojeto de Código Tributário de Enno Becker, a pessoa que possuísse um objeto como seu seria tratada como proprietária no sentido da lei tributária. Aderindo a esse pensamento, Dino Jarach manifestou entendimento segundo o qual o fato gerador do imposto de renda exigia a posse da renda - e não necessariamente a propriedade. Após compendiar a doutrina alienígena apoiada na interpretação econômica, Brandão Machado nos noticia que os autores do anteprojeto de nosso CTN, particularmente Rubens Gomes de Souza, pretenderam conservar o pensamento da doutrina alemã com a redação do artigo 43 do CTN, nomeadamente ao se referir à disponibilidade econômica de renda ${ }^{189}$.

Mais recentemente, Luís Eduardo Schoueri, em artigo com o sugestivo título de $O$ mito do Lucro Real, afirma que o legislador tributário nem sempre alude aos signos com acepção consagrada pela linguagem jurídica. Por conta disso, o acréscimo patrimonial referido pelo artigo 43 do CTN não está, necessariamente, ligado à acepção tradicional de patrimônio, até porque o direito privado encaparia mais de uma acepção para esse signo (cita, como exemplo, a noção de patrimônio albergada pela LSA, particularmente no que

\footnotetext{
${ }^{189}$ MACHADO, Brandão. Breve Exame Crítico do Art. 43 do CTN. In: MARTINS, Ives Gandra da Silva (coord.). Estudos sobre o Imposto de Renda (Em memória de Henry Tilbery). São Paulo: Resenha Tributária, 1994. ps. 117 e 118.
} 
tange à disciplina das demonstrações financeiras ${ }^{190}$ ). Amparado por essas premissas, o Titular de Direito Tributário da Universidade de São Paulo conclui estar o termo disponibilidade ligada ao poder de empregar os recursos para a destinação que lhe aprouver, independentemente daquilo que chama de mera formalidade jurídica. Dá o exemplo do acionista controlador que tem plena disponibilidade (na acepção por ele utilizada) sobre os lucros auferidos por sua controlada ${ }^{191}$.

Entretanto, não nos parecem acertadas a teoria da propriedade econômica e a definição de disponibilidade conferida por Luís Eduardo Schoueri para efeitos de interpretação do artigo 43 do CTN. Em nosso pensar, as explicações suportadas por essas teorias conflitam com o estado ideal de coisas a ser protegido pelo princípio da capacidade contributiva. Vejamos.

A posse de um bem, por si só, não representa manifestação de capacidade para contribuir com as despesas gerais do Estado (capacidade contributiva objetiva). Não negamos juridicidade à posse de um bem; também não negamos que o direito à posse de determinado bem possa ingressar no conjunto de direitos de um sujeito, portanto, pertencendo ao patrimônio. Porém, o que não admitimos é que o mero possuidor de fato (sem qualquer título jurídico) do bem tenha, necessariamente, capacidade para contribuir com as despesas gerais do Estado. Veja-se o exemplo de um caseiro, humilde trabalhador rural, que, mesmo sem permissão do proprietário da fazenda, ingressa e usufrui de todas as instalações e benfeitorias da propriedade, como o campo de futebol, a piscina, a churrasqueira. Ele, de fato, tem a posse da propriedade e usufruiu de suas utilidades, porém, nem por isso tem capacidade para contribuir com as despesas gerais do Estado de forma semelhante ao legítimo proprietário da fazenda.

Luís Eduardo Schoueri afirma ser incoerente a propriedade jurídica para efeitos de imposto de renda, apontando o exemplo de um sujeito que, pela prática de atos ilícitos, adquire e usufrui de uma série de bens imóveis, todos em nome de laranjas $^{192}$. O exemplo não nos convence. O sistema do direito apresenta expedientes para restabelecer o status quo ante, isto é, retirar-lhe todos os bens e expressões monetárias auferidos pela prática de atos ilícitos. Após a aplicação do direito, não haverá que se falar em renda a ser

\footnotetext{
${ }^{190}$ Esse argumento foi objeto de críticas no item precedente (3.2.3 - Breves Considerações sobre o Patrimônio).

${ }^{191}$ SCHOUERI, Luís Eduardo. O mito do Lucro Real na Passagem da Disponibilidade Jurídica para a Disponibilidade Econômica. In: MOSQUERA, Roberto Quiroga. LOPES, Alexsandro Broedel (coords.). Controvérsias Jurídico-Contábeis (aproximações e distanciamentos). São Paulo, Dialética, 2010. p. 252.

192 Cf. SCHOUERI, Luís Eduardo. O mito do Lucro Real na Passagem da Disponibilidade Jurídica para a Disponibilidade Econômica. In: MOSQUERA, Roberto Quiroga. LOPES, Alexsandro Broedel (coords.). Controvérsias Jurídico-Contábeis (aproximações e distanciamentos). São Paulo, Dialética, 2010. p. 260.
} 
tributada para o sujeito que praticou os atos ilícitos. Ademais, ainda que isso não venha a ser feito por patologias (ausência de aplicação do direito), o Direito Tributário, particularmente a legislação do imposto de renda, registra expedientes para exigir o imposto do laranja (acréscimo patrimonial a descoberto, por exemplo) e, via execução fiscal, retirar-lhe a propriedade do bem imóvel ante a ausência de pagamento do tributo correspondente.

Tanto no exemplo do humilde caseiro, quanto no do sujeito que, com o produto de atos ilícitos, usufruiu de bens imóveis, ocorre aquilo que a doutrina chama de renda psíquica, isto é, fluxo de sentimentos de satisfação que os indivíduos têm do consumo de bens e serviços ${ }^{193}$. Todavia, isso, por si só, não representa manifestação de capacidade para contribuir com as despesas estatais, ainda que, da perspectiva meramente da ciência econômica, essa noção possa ter alguma relevância.

Ademais, não nos parece ser acertada a definição de Luís Eduardo Schoueri sobre disponibilidade. Aquilo que o respeitado Professor das Arcadas chama de mera formalidade jurídica, em verdade, representa ato constitutivo do direito, antes do qual há um vazio no mundo jurídico. A chamada mera formalidade, tratada sem o devido merecimento pelo autor, distingue, em verdade, o direito do não direito. A tributação dos lucros auferidos por controlada antes da deliberação de distribuição dos dividendos contraria o estado ideal de coisas a ser preservado pela capacidade contributiva, na medida em que, se não distribuídos, presume-se que a controladora entende que o investimento não está maduro o suficiente para sua descapitalização (distribuição de dividendos). Assim, ela (a controladora) fica sujeita a deixar de auferir (receber, efetivamente) tais lucros ante a ocorrência de prejuízos futuros.

Rejeitamos, portanto, as acepções de disponibilidade econômica conferidas pela doutrina alemã da propriedade econômica e aquela dada pelo Professor Luís Eduardo Schoueri. Parece-nos que está com a razão Brandão Machado, o qual defende ser a expressão disponibilidade econômica destituía de valor e eficácia, na medida em que não seria razoável falar em disponibilidade econômica de acréscimo patrimonial de direitos ${ }^{194}$.

\footnotetext{
${ }^{193}$ Cf. HOLMES, Kevin. The Concept of Income. A Multi-Disciplinary Analysis. The Netherlands. IBFD Publications BV, 2000. ps. 36 e 37.

${ }^{194}$ MACHADO, Brandão. Breve Exame Crítico do Art. 43 do CTN. In: MARTINS, Ives Gandra da Silva (coord.). Estudos sobre o Imposto de Renda (Em memória de Henry Tilbery). São Paulo: Resenha Tributária, 1994. p. 115.
} 
O que serve de fundamento para a tributação da renda é o patrimônio, assim entendido em sua acepção jurídica, como explicitado no item 3.2.3, acima ${ }^{195}$. Tudo o que for além, contraria o estado ideal de coisas a se preservado pelo princípio da capacidade contributiva. Para fins de atendimento da capacidade contributiva objetiva, não há lugar para qualquer outra acepção de patrimônio, idealizado com propósitos específicos e que abrigue expectativas de direitos.

Com efeito, para fins do presente estudo, adotaremos a distinção entre disponibilidade jurídica e econômica a partir do critério regime de competência e regime de caixa, aliás, acepção adotada pela maioria da doutrina pátria.

\subsubsection{O PRINCÍPIO DA REALIZAÇÃO DA RENDA ENQUANTO APLICAÇÃO DO PRINCÍPIO DA CAPACIDADE CONTRIBUTIVA}

Interessa-nos, para o desenvolvimento do presente estudo, investigar se as valorizações de preço de direitos integrantes do patrimônio dos contribuintes, decorrentes de avaliações ou variações típicas de mercado, são suficientes para, por si só, ensejar a tributação da renda. Nesse ponto, é comum a doutrina se referir à realização da renda ou do lucro (ou princípio da realização da renda) como norte para aferir o momento da tributação. Em suma, nosso desafio será aferir se a tributação da renda pode ocorrer por ocasião da mera valorização no mercado do direito ou, oposto disso, apenas quando da efetiva cessão do direito por meio de troca no mercado.

Tomada a renda como fenômeno meramente econômico, enquanto manifestação do poder do individuo de satisfazer suas vontades, a valorização de ativos representaria, na lição de Kelvin Holmes, acréscimo patrimonial, independentemente da efetiva troca no mercado ${ }^{196}$.

Todavia, relembre-se que a autorização constitucional para tributação da renda encontra limites no princípio da capacidade contributiva. Nesse diapasão, Victor Borges Polizelli, em seu estudo sobre o princípio da realização da renda, argutamente aduz:

\footnotetext{
${ }^{195}$ Nesse sentido, Ricardo Mariz de Oliveira (Fundamentos do Imposto de Renda. São Paulo: Quartier Latin, 2008. p. 67 e ss.) e Roque Antonio Carrazza (Imposto sobre a Renda (perfil constitucional e temas específicos). 3a. ed. São Paulo: Malheiros, 2009. p. 41.)

196 "The increase or accretion to one's power to satisfy his wants in a given period so far as that power consists of (a) money itself, or, (b) anything susceptible of valuation in terms of money." (HOLMES, Kevin. The Concept of Income. A Multi-Disciplinary Analysis. The Netherlands. IBFD Publications BV, 2000. p. 59).
} 
“(...) a seleção do evento crucial ou determinante, dentre os diversos eventos de realização identificáveis no conjunto dos fatos econômicos subjacentes e, principalmente, a fixação de momentos temporais diferenciados (em caráter de exceção) para situações e contribuintes específicos dependerão, enfim, de escolhas legislativas, administrativas e jurisprudenciais que, em última análise, remontam à aplicação dos sobreprincípios da igualdade e da capacidade contributiva."197

Mesmo com essa ressalva, o autor, apoiado por Boris Bitteker e Ricci Umberto, acolhe entendimento segundo o qual a proposta abrangente do conceito de renda do modelo $\mathrm{SHS}^{198}$, a qual inclui lucros não realizados, "permitiria uma distribuição da carga tributária, avaliando-se a capacidade contributiva relativa à renda de forma mais precisa. Se o propósito é tributar conforme a capacidade contributiva, por conseguinte a definição deve ser a mais abrangente possível." 199

Todavia, não somos da mesma opinião. Para nós, a mera satisfação (ou bemestar) decorrente da valorização pelo mercado de um ativo não revela capacidade para contribuir com as despesas gerais do Estado (capacidade contributiva objetiva). Relembrese que o estado ideal de coisas a ser preservado pelo indigitado princípio pressupõe a coparticipação do sujeito passivo nas despesas do Estado à medida de seus êxitos econômicos já conquistados (e não expectativas de conquistar). Vale dizer, o Estado esbulhará parcela do patrimônio dos cidadãos, o qual, é importante sublinhar, refere-se ao patrimônio presente - e não mera expectativa de patrimônio. A mais-valia decorrente da valorização do bem representa, antes da troca no mercado, mera expectativa de ingresso patrimonial.

Analisando esse aspecto da capacidade contributiva, Miguel Delgado Gutierrez assevera:

“A expectativa de uma pessoa de ter o seu patrimônio aumentado não evidencia uma capacidade econômica de pagar tributos. Ocorre uma tributação sobre um ganho virtual, já que a mais-valia só é certa quando ocorre a

\footnotetext{
${ }^{197}$ POLIZELLI, Victor Borges. O Princípio da Realização da Renda e sua Aplicação no Imposto de Renda das Pessoas Jurídicas. Dissertação. Mestrado. Universidade de São Paulo, 2009. p. 17.

${ }^{198}$ Vide breve explicação sobre o modelo SHS no item 2.1.2, acima.

199 Cf. POLIZELLI, Victor Borges. O Princípio da Realização da Renda e sua Aplicação no Imposto de Renda das Pessoas Jurídicas. Dissertação. Mestrado. Universidade de São Paulo, 2009. p. 38.
} 
realização, ou seja, quando é alienado o direito real ou pessoal do contribuinte.",200

Nessa mesma linha, Roberto Quiroga Mosquera aduz:

“(...) a expectativa de direito não é elemento patrimonial, não representa direito real ou pessoal do indivíduo. Não se detém a propriedade de esperanças, anseios, expectativas. Os direitos patrimoniais representam relações jurídicas que efetivamente são apreciáveis economicamente."201

No Brasil, por determinação do Decreto-Lei $n^{\circ}$ 1.598/77, a reavaliação contábil de ativos não se sujeita à tributação antes da efetiva realização. E assim foi justificado pelo Ministro da Fazenda que encaminhou o projeto do Decreto-Lei, conforme Exposição de Motivos, para atender a capacidade do contribuinte para suportar o ônus tributário ${ }^{202}$. Eis, portanto, a função bloqueadora do princípio da capacidade contributiva reconhecida pela própria fiscalização.

Rejeitamos o argumento de que a não tributação da valorização violaria a igualdade, porquanto diferenciaria dois contribuintes com a mesma quantia de ganho econômico $^{203}$. Não há que se falar em tratamento anti-isonômico nessa situação. Aquele contribuinte que, alienando o ativo, efetivamente obteve êxito econômico, integrando ao seu patrimônio a mais-valia decorrente da valorização do ativo. A atividade de efetiva troca no mercado não pode ser relegada a um plano secundário, como se o ato de comercializar fosse banal e não exigisse técnicas específicas. É esse ato que revela a capacidade contributiva objetiva; é esse ato, relegado por alguns, que distingue aquele contribuinte que tem capacidade para contribuir com os encargos fiscais daquele que não tem. O contribuinte que, tendo um ativo valorizado pelo mercado, porém, ainda não realizado, encontra-se em situação manifestamente distinta - e desfavorável - se comparado com aquele primeiro.

Em suma, a tributação da mera valorização de ativo representaria participação presente do Estado no patrimônio futuro do contribuinte, estando, com efeito, em

\footnotetext{
${ }^{200}$ GUTIERREZ, Miguel Delgado. O Imposto de Renda e os Princípios da Generalidade, da Universalidade e da Progressividade. Tese. Doutorado. Universidade de São Paulo, 2009. p. 131.

${ }^{201}$ MOSQUERA, Roberto Quiroga. O Conceito Constitucional de Renda e Proventos de Qualquer Natureza. Dissertação. Mestrado. Pontifícia Universidade Católica de São Paulo, 1996. p. 128.

202 "17. O projeto adota a orientação geral de submeter os ganhos de capital ao imposto somente quando realizados, isto é, quando a pessoa jurídica tem condições financeiras para suportar o ônus tributário." (apud PEDREIRA, José Luiz Bulhões. Imposto sobre a Renda - Pessoas Jurídicas. Vol. I. Rio de Janeiro: Justec, 1979. p. 289.).

${ }^{203}$ Cf. Peter Kavelaars (apud POLIZELLI, Victor Borges. O Princípio da Realização da Renda e sua Aplicação no Imposto de Renda das Pessoas Jurídicas. Dissertação. Mestrado. Universidade de São Paulo, 2009. p. 43.)
} 
desconformidade com o estado ideal de coisas a ser preservado pelo princípio da capacidade contributiva. 


\section{CONCLUSÕES DA PARTE I: FUNDAMENTOS PARA POSTERIOR CONFRONTO COM O LUCRO CONTÁBIL}

1. Nosso Sistema Tributário Nacional é marcado por extensa disciplina no Texto Supremo, tolhendo em alto grau a liberdade do legislador infraconstitucional no mister de regular a legislação tributária.

2. E assim se fez, dentre outros motivos, para preservar o modelo brasileiro de Federação (equilíbrio entre os entes federativos), o qual somente poderá ser alterado via emenda constitucional, o que implica dizer que não poderá sê-lo na forma de invasão de competência tributária por um ente político.

3. A distribuição de competências tributárias se deu por meio de indicação de fatos-signos presuntivos de renda ou capital (i.e, patrimônio). Para melhor compreender esses fatos-signos, surgem, de imediato, três possibilidades interpretativas, quais sejam: (i) os diversos vocábulos constantes do Texto Constitucional devem ter sua significação construída a partir de exegese eminentemente constitucional; (ii) os signos constitucionais devem ser entendidos como tipos, na acepção de ordens abertas, fluidas, cujos precisos contornos de seus significados dependerão do que vierem a dispor as leis complementares; e (iii) os efetivos significados das referências sígnicas constitucionais dependerão do que vierem a dispor as leis ordinárias, que têm papel de fixá-los livremente.

4. No que tange à última possibilidade, parece-nos facilmente descartável, eis que (i) não se compatibiliza com a rigidez do Sistema Tributário Nacional e (ii) a interpretação constitucional não depende, pelo menos em tamanha magnitude, do direito infraconstitucional, eis que os signos constitucionais possuem conteúdo semântico, ainda que mínimo.

5. Já no que respeita ao confronto entre as duas primeiras, quer-nos parecer que os signos adotados pela $\mathrm{CF} / 88$ para discriminação de competências tributárias possuem diferentes níveis de indeterminação, podendo alguns se apresentarem na forma de conceitos determinados e outros na de tipos (como é exemplo eloquente o imposto sobre grandes fortunas).

6. Todavia, quanto à predominância de um ou de outro (conceito ou tipo), não admitimos, aprioristicamente, que deve o intérprete partir da premissa de que o constituinte pretendeu apenas inserir tipos, dando ampla liberdade para o legislador complementar 
disciplinar os contornos da competência dos entes da Federação. No mínimo, por dois motivos: (i) pela rigidez que o constituinte dispensou ao Sistema Tributário Nacional, seja para proteger o modelo Federativo que ele desejava, seja pela insistente preocupação com a segurança jurídica e previsibilidade em prol dos contribuintes; e (ii) pelo fato de que os signos empregados pelo constituinte, embora não escapem dos vícios inerentes à linguagem, apresentam um grau de determinação relativamente elevado.

7. No mister de construir o significado desses signos constitucionais, o exegeta se deparará com vícios de linguagem, como a vaguidade e a ambiguidade semântica, tendo de eleger, dentre as várias possibilidades existentes, o conteúdo semântico consentâneo com o sistema jurídico, assim como identificar contornos ao núcleo semântico do signo estudado. 8. Na construção do significado dos signos constitucional-tributários, deve o intérprete iniciar seu trabalho pela identificação da acepção de base, podendo ela ser, em sua origem, um conceito autônomos stricto sensu, um conceito recepcionado jurídico ou um conceito recepcionado extrajurídico.

9. Esse caminho metodológico funda-se na idéia de que o legislador constituinte não partiu do nada, não iniciou seu caminho de um vácuo normativo e social. A idéia de inauguração jurídica de um Estado de Direito Brasileiro não é incompatível com a noção de que ele (o constituinte) valeu-se da realidade social existente na época e mesmo sobre o ordenamento jurídico infraconstitucional, para ali recolher subsídios, elementos, informações, institutos e conceitos, e utilizá-los na elaboração da nova Carta, inclusive com a recepção dos diplomas legais vigentes que não contrariassem os comandos superiores daquela.

10. No que tange ao signo renda, após analisar as acepções comum, técnicaeconômica e jurídica no contexto pré-constitucional, concluímos estar a acepção de base ligada a acréscimo de patrimônio verificado entre dois marcos temporais.

11. Essa acepção de base passa pelo teste da recepção pelo Texto Supremo, não sendo incompatível com ele. Tal conclusão pode ser extraída tanto pela técnica da delimitação positiva da regra de competência, quanto pela da delimitação negativa.

12. De todo modo, não ignoramos que tal significado não soluciona todas as dúvidas e problemas que cercam o tema do aspecto material do imposto de renda. Porém, deve o intérprete, para identificar os requisitos para uma tributação constitucional da renda, valer-se de todo o sistema. Isso só confirma a noção de que a renda constitucionalmente tributável não tem relação apenas com seu conceito; tem relação com todas as limitações que o sistema constitucional impõe, tal como o princípio da capacidade contributiva. 
13. Os princípios jurídicos, longe de representarem meras normas programáticas, estabelecem um estado ideal de coisas, encerrando, assim, uma função bloqueadora, isto é, afastamento de elementos expressamente previstos que sejam incompatíveis com o estado ideal de coisas a ser promovido pelo princípio.

14. Dentre as funções bloqueadoras do princípio da capacidade contributiva, demos, no presente trabalho, destaque ao que a doutrina costuma chamar de capacidade contributiva objetiva (ou absoluta). Significa dizer que, como medida de justiça fiscal para o regime dos impostos, somente podem ser objeto de tributação fatos que representem êxito econômico.

15. Nesse sentido, o índice para aferir tal êxito e revelar capacidade para contribuir com as despesas gerais do Estado é o patrimônio, entendido na sua acepção estritamente jurídica (não porque advinda do Direito Civil, mas porque é uma entidade lógica própria da Teoria Geral do Direito). Portanto, o patrimônio encerra um limite intransponível para medição da capacidade para contribuir com as despesas gerais do Estado. Fora disso, estarse-á burlando o estado ideal de coisas a ser preservado pelo princípio da capacidade contributiva.

16. É o patrimônio - tomado na sua acepção jurídica (conjunto ou universalidade de relações jurídicas de um sujeito de direito, sejam aquelas em que esse sujeito figure no polo ativo ou noutras em que ele aparece no polo passivo) - que revela manifestação para contribuir com as despesas gerais do Estado. Nessa acepção de patrimônio, somente estão inseridas as conquistas econômicas presentes - e não expectativas futuras. Daí dizer que o estado ideal de coisas a ser preservado pelo princípio da capacidade contributiva é negar a tributação por meras expectativas de conquistas, anseios de êxitos econômicos. No patrimônio somente há êxitos econômicos presentes - e não expectativas.

17. Derivam das conclusões acima duas premissas de importância capital para confrontarmos a renda constitucionalmente tributável e o lucro apurado de acordo com a lei societária.

18. Primeira: para identificação da renda constitucionalmente tributável, apenas devem ser levados em conta os aspectos jurídicos dos ativos e passivos patrimoniais - em detrimento de valorações extraídas de perspectivas que interessam apenas à ciência econômica (renda psíquica, por exemplo). Daí porque, no que tange à compreensão do significado de disponibilidade econômica de renda (artigo 43 do $\mathrm{CTN}$ ), não se admite a teoria da propriedade econômica desenvolvida na Alemanha. 
19. Segunda: a mera valorização de ativo (por avaliação de mercado, por exemplo) não denota capacidade para contribuir com as despesas gerais do Estado, sendo mera expectativa, anseio de acréscimo de patrimônio. Eis a compreensão do princípio da realização da renda de acordo com o princípio da capacidade contributiva. 


\section{PARTE II}

O IMPOSTO DE RENDA DAS PESSOAS JURÍDICAS NA LEI ORDINÁRIA.

A CONTABILIDADE COMO INSTRUMENTO PARA

IDENTIFICAÇÃO DA BASE TRIBUTÁVEL.

CONFRONTO COM A RENDA CONSTITUCIONALMENTE

TRIBUTÁVEL. 


\section{5. A CONTABILIDADE E SUA JURIDICIZAÇÃO}

\subsection{A CONTABILIDADE}

\subsubsection{BREVE CONTEXTUALIZAÇÃO HISTÓRICA: DA NECESSIDADE DE CONTROLE À PADRONIZAÇÃO INTERNACIONAL DE PROCEDIMENTOS CONTÁBEIS}

De existência bastante antiga, a contabilidade evoluiu e acompanhou as transformações cultural e econômica do homem. Com a complexidade das relações intersubjetivas, nasceu, para o homem, a necessidade de dominar as informações de seu patrimônio, visando adequado controle e organização. Tal necessidade não é de hoje. Desde os tempos mais primitivos ${ }^{204}$, os homens necessitavam de um eficaz sistema de informações do patrimônio, revelando-se o exercício de uma das mais importantes vertentes da contabilidade: o controle ${ }^{205}$.

Com o passar dos tempos, tornou-se necessária a difusão de métodos uniformes aptos a descrever, numa linguagem e metodologia próprias, a realidade patrimonial de forma acessível e compreensível por grande parte dos usuários. E assim era preciso, sob pena de cada organização estabelecer critérios próprios, utilizando-os na elaboração de seus relatórios contábeis, não possibilitando aos usuários externos das informações contábeis (investidores, governo, clientes, fornecedores, etc.) uma interpretação adequada e uniforme àquelas ferramentas ${ }^{206}$.

\footnotetext{
204 "O fato é que vários eventos muito antigos, vinculados a algumas descobertas arqueológicas, demonstram a existência de formas de controle, muitas vezes, bastante complexas para a época e que nos permitem afirmar a existência da contabilidade, mesmo que de forma primitiva, na vida das pessoas daquele período." (COELHO, Cláudio Ulysses Ferreira; LINS, Luiz dos Santos. Teoria da Contabilidade. Abordagem Contextual, Histórica e Gerencial. São Paulo: Atlas, 2010. p. 118.)

205 "Essa nova fase do desenvolvimento do homem na terra, principalmente nas áreas mais férteis, como a antiga Pérsia e a Mesopotâmia, criou uma necessidade até então pouco considerada: o controle do produto da agricultura e da criação de animais." (SCHMIDT, Paulo. História do Pensamento Contábil, Porto Alegre: Bookman, 2000. p. 15.)

${ }^{206}$ Cf. PÊGAS, Paulo Henrique. Manual de Contabilidade Tributária: teoria e prática. Rio de Janeiro: Freitas Bastos, 2004. p. 14.
} 
Com efeito, a uniformização dos métodos contábeis universais em grande escala foi visto pela primeira vez nos séculos XII e XIII ${ }^{207}$. Verificou-se, a partir disso, uma evolução na contabilidade no que tange ao desenvolvimento de sistemas para controle de toda movimentação patrimonial, começando a surgir as primeiras grandes obras que deram um passo decisivo para a fixação da contabilidade como um instrumento útil no controle patrimonial $^{208}$.

Merece destaque o Renascimento, período marcado pelo fim da Idade Média e o início da Moderna, o qual foi decisivo para a contabilidade assumir caráter científico. Isso decorreu do desenvolvimento das atividades financeira, comercial e cultural, as quais demandaram maiores informações e o surgimento de novos usuários, notadamente os credores, os investidores e o próprio Estado ${ }^{209}$. Note-se que, durante o período anterior ao Renascimento (que se estende até o século XVI), o principal objetivo da contabilidade era produzir informação para o proprietário - geralmente proprietário único. Em consequência, as contas eram mantidas em sigilo e não havia pressão externa, como hoje, no sentido de exatidão ou da adoção de padrões uniformes de divulgação ${ }^{210}$.

Vê-se, portanto, que a preocupação com a adoção de padrões uniformes de contabilidade - iniciada com mais vigor no Renascimento - tornou-se cada vez mais relevante a ponto de, no contexto econômico atual, ser medida implementada não só regionalmente, mas de maneira global pelos principais mercados do mundo. Isso ocorre, em última análise, pelo fato de os problemas sociais e econômicos não serem mais localizados ou próprios de uma região ou país ${ }^{211}$. Eis a tão divulgada globalização.

O Brasil não está alheio a isso tudo. Como se verá no curso do presente capítulo, os organismos contábeis brasileiros (CPC, CFC, CVM, etc.), atendendo disposições da lei societária, têm adotado os IFRS, normas contábeis editadas por um importante organismo internacional contábil, o IASB. Estamos falando da chamada convergência contábil internacional, a qual se revela importante instrumento de redução

\footnotetext{
207 "Pesquisas sobre a origem das técnicas de escrituração contábil transportam para o período entre os séculos XII e XIII, no norte da Itália, quando ocorreram as primeiras manifestações práticas do uso do sistema de partidas dobradas em empresas. Após essas primeiras práticas contábeis é que seu uso generalizou-se por toda a Europa" (SCHMIDT, Paulo. História do Pensamento Contábil, Porto Alegre: Bookman, 2000. p. 25.)

${ }^{208}$ Cf. SCHMIDT, Paulo. História do Pensamento Contábil, Porto Alegre: Bookman, 2000. p. 24.

${ }^{209}$ Cf. COELHO, Cláudio Ulysses Ferreira; LINS, Luiz dos Santos. Teoria da Contabilidade. Abordagem Contextual, Histórica e Gerencial. São Paulo: Atlas, 2010. p. 122 e ss.

${ }^{210}$ Cf. HENDRIKSEN, Eldon S.; BREDA, Michael F. Van. Teoria da Contabilidade. 1. ed. 8. reimpr. Tradução de Antonio Zoratto Sanvicente. São Paulo: Atlas, 2010. p. 40.

${ }^{211}$ Cf. COELHO, Cláudio Ulysses Ferreira; LINS, Luiz dos Santos. Teoria da Contabilidade. Abordagem Contextual, Histórica e Gerencial. São Paulo: Atlas, 2010. p. 3.
} 
de custos de conciliação entre distintos padrões contábeis e, em última análise, expediente útil para facilitar o acesso das empresas brasileiras a capitais externos. Ou, como se manifestou a CVM, o que se busca hoje é a “(...) eliminação de algumas barreiras regulatórias que impediam a inserção total das companhias abertas no processo de convergência contábil internacional (...)."212

\subsubsection{FUNÇÕES: DO CONTROLE PATRIMONIAL DIRIGIDO AO PROPRIETÁrio AO INTERESSE COMUM PELA PREDIÇÃo DE FLUXOS DE CAIXA FUTUROS (INFORMATION APPROACH)}

A contabilidade é, como se pôde perceber da exposição supra, um sistema de informação e avaliação destinado a prover seus usuários com demonstrações e análises de natureza econômica, financeira, física e de produtividades, com relação à entidade objeto de contabilização ${ }^{213}$.

Além do controle do patrimônio unicamente pelo proprietário, a contabilidade, ao longo dos tempos, foi agregando outras funções, como a análise da condição patrimonial, a mensuração dos componentes desse patrimônio, a evidenciação dos fatos contábeis, o resumo informativo e auxílio da condução gerencial do empreendimento ${ }^{214}$.

São os usuários (e suas necessidades em face das constantes transformações sociais, econômicas e financeiras) os grandes responsáveis pela evolução da contabilidade. Por conta deles, ou melhor, do aumento de usuários da informação contábil, é que a contabilidade evoluiu, passando de relatório destinado especificamente ao proprietário para relatório condizente com padrão internacionalmente uniforme, seguindo, neste particular, as orientações do IASB.

Parece-nos, portanto, que a contabilidade e sua evolução podem ser explicadas a partir das necessidades e das especificidades de seus usuários. Dentre os usuários, destacam-se:

(i) os investidores atuais e potenciais: interessados em informações que deem suporte às decisões de compra, venda ou manutenção dos investimentos e, em especial, à

\footnotetext{
${ }^{212}$ Comunicado ao Mercado emitido pela CVM em janeiro de 2008.

${ }^{213}$ Cf. IUDÍCIUS, Sérgio de; GELBCKE, Ernesto Rubens; MARTINS, Eliseu. Manual de Contabilidade das Sociedades por Ações: aplicável às demais sociedades. 6a ed., ver. e atual. São Paulo: Atlas, 2003. p. 48.

${ }^{214}$ Cf. COELHO, Cláudio Ulysses Ferreira; LINS, Luiz dos Santos. Teoria da Contabilidade. Abordagem Contextual, Histórica e Gerencial. São Paulo: Atlas, 2010. p. 117.
} 
capacidade de geração de dividendos. Esse usuário ganhou grande relevo, sobretudo dada a importância do mercado de capitais na economia contemporânea global;

(ii) empregados: interessados no grau de estabilidade da entidade, além de capacidade de prover remunerações, benefícios atuais e previdenciários;

(iii) credores por empréstimos: interessados na capacidade de pagamento dos empréstimos e juros contratados;

(iv) fornecedores e outros credores comerciais: interessados na capacidade de pagamento de seus créditos na data contratada;

(v) clientes: interessados na continuidade operacional da entidade, notadamente quando se tratar de relações de longo prazo;

(vi) estado: interesse em relação a assuntos regulatórios e tributários;

(vii) público em geral: notadamente no que diz respeito a entidades que realizam importantes investimentos regionais.

Diante da multiplicidade de usuários, surge um problema. Indaga-se se um mesmo relatório tem o condão de auxiliar e atender os mais diversos interesses.

Esse problema não passou despercebido pelos estudiosos da contabilidade. Nesse sentido, Eliseu Martins e Paulo Roberto da Silva apontam duas alternativas, quais sejam: (i) elaborar vários conjuntos de relatórios, para atender os usuários que exigem e têm poder para conseguir as informações que desejam; ou (ii) elaborar um relatório com grande variedade de informações capaz de atender às necessidades de quase todos os interessados. Os autores apontam que a primeira alternativa parece mesmo prevalecer, bastando, para tanto, averiguar as exigências específicas do fisco, do Banco Central, da CVM, controladores no exterior, gestores internos, potenciais compradores, etc. Porém, vislumbram o início de um movimento migratório para um reduzido número de relatórios que proporcionem variadas informações ${ }^{215}$.

Ao que nos parece, esse movimento migratório se deve ao fato de que, embora sejam inúmeros usuários, há pontos convergentes entre eles. Do CPC Básico - nitidamente inspirado no IAS 1 (Conceptual Framework) - se extrai que nem todas as necessidades de informações podem ser satisfeitas pelas demonstrações contábeis, mas, por outro lado, existem informações cujas necessidades são comuns a todos os usuários ${ }^{216}$.

${ }^{215}$ MARTINS, Eliseu; SILVA, Paulo Roberto da. Introdução. In: Avaliação de empresas: da mensuração contábil à econômica. Eliseu Martins (coord.). 1. ed. 6. reimpr. São Paulo: Atlas, 2009. p. 19.

${ }^{216}$ Item 10. 
No que tange a essas necessidades comuns, urge sublinhar o importante comentário de Eldon S. Hendriksen e Michael F. van Breda, para quem "os usuários da contabilidade são numerosos e diversificados, mas parecem ter um interesse comum na predição de fluxos de caixa futuros." 217 .

Nesse mesmo diapasão, o FASB atestou o seguinte por meio de pronunciamento entitulado Objectives of Financial Reporting by Business Entreprises:

"A divulgação financeira deve fornecer informações que sejam úteis para investidores e credores atuais e em potencial, bem como para outros usuários que visem a tomada racional de decisões de investimentos, crédito e outras semelhantes. (...) a divulgação financeira deve proporcionar informações que ajudem investidores, credores e outros a avaliar os volumes, a distribuição no tempo e incerteza das possíveis entradas líquidas futuras de caixa da empresa." 218

Destarte, podemos asseverar que a contabilidade - sem levar em conta as especificidades de um ou outro usuário, mas sim de algumas necessidades comuns a eles pode ser compreendida como instrumento para identificar e mensurar a capacidade de geração futura de caixa ou equivalentes. Se assim for, a contabilidade estará a serviço de seus usuários para tomada de decisões prospectivas, dado que elas (as decisões) são tomadas pelos usuários das demonstrações contábeis a partir da avaliação da capacidade que a entidade tem para gerar caixa e equivalentes de caixa ${ }^{219}$.

A contabilidade, portanto, não se limita a atestar a ocorrência de eventos no passado; somente com isso, ela não atingiria seus propósitos (servir como instrumento para tomada de decisões). Em verdade, os eventos passados são registrados pelos contabilistas de maneira que se possa prever a geração futura da caixa. A informação contábil tem uma função eminentemente preditiva ${ }^{220}$ : registra-se o passado mirando-se para o futuro e, assim, amparam-se os usuários em suas decisões.

Tal perspectiva da contabilidade foi denominada information approach ou perspectiva da informação. Alexsandro Broedel Lopes e Roberto Quiroga Mosquera

${ }^{217}$ HENDRIKSEN, Eldon S.; BREDA, Michael F. Van. Teoria da Contabilidade. 1. ed. 8. reimpr. Tradução de Antonio Zoratto Sanvicente. São Paulo: Atlas, 2010. p. 113.

${ }^{218}$ HENDRIKSEN, Eldon S.; BREDA, Michael F. Van. Teoria da Contabilidade. 1. ed. 8. reimpr. Tradução de Antonio Zoratto Sanvicente. São Paulo: Atlas, 2010. p. 93.

${ }^{219}$ Cf. COELHO, Cláudio Ulysses Ferreira; LINS, Luiz dos Santos. Teoria da Contabilidade. Abordagem Contextual, Histórica e Gerencial. São Paulo: Atlas, 2010. 186.

${ }^{220}$ Cf. MOSQUERA, Roberto Quiroga; LOPES, Alexsandro Broedel. O Direito Contábil - Fundamentos Conceituais, Aspectos da Experiência Brasileira e Implicações. In: MOSQUERA, Roberto Quiroga. LOPES, Alexsandro Broedel (coords.). Controvérsias Jurídico-Contábeis (aproximações e distanciamentos). São Paulo, Dialética, 2010. p. 74. 
chamam atenção ao movimento surgindo nos Estados Unidos da América, a partir dos anos 1960, que revolucionou o estudo da contabilidade. Em vez de a contabilidade refletir a realidade econômica por intermédio da construção de números que possuíssem certas características pré-definidas (a chamada escola normativista), a contabilidade passou a ser vista sob a perspectiva da informação, segundo a qual ela deveria ser vista enquanto sofisticado instrumento de informação aos usuários externos das demonstrações ${ }^{221}$.

É essa perspectiva que influenciou o FASB, o IASB e, no Brasil, o CPC. Inspirado por esses valores e objetivos é que se faz contabilidade no Brasil, notadamente a partir de 2008, com a vigência da Lei $n^{\circ} 11.638 / 07$, e nos principais mercados do mundo $^{222}$. É sob essa perspectiva que deve ser encarada a LSA, particularmente no que toca às disposições relativas às demonstrações financeiras.

\subsubsection{IMPACTOS DO INFORMATION APPROACH NA ELABORAÇÃO DE RELATÓRIOS CONTÁBEIS}

Dissemos antes que a atual perspectiva da contabilidade consiste em servir como instrumento de informações a seus usuários para decisões prospectivas e, para tanto, ganha relevo crucial a análise da capacidade de geração futura de caixa ou equivalentes.

Se assim é, parece natural que as formas de registros contábeis se modifiquem, evoluindo na direção dessa nova perspectiva da contabilidade (information aproach), de modo que se privilegie a contabilidade enquanto instrumento de informação para tomada de decisões prospectivas. E assim se faz em detrimento de qualquer outro objetivo ${ }^{223}$. Afinal de contas, de nada adianta adotar no plano ideal tais e quais valores, porém, não implementá-los no mundo concreto.

Para que essa afirmação não fique apenas no plano abstrato, prejudicando a compreensão do leitor sobre a atual perspectiva da contabilidade, vejamos o exemplo da

\footnotetext{
${ }^{221}$ Cf. MOSQUERA, Roberto Quiroga; LOPES, Alexsandro Broedel. O Direito Contábil - Fundamentos Conceituais, Aspectos da Experiência Brasileira e Implicações. In: MOSQUERA, Roberto Quiroga. LOPES, Alexsandro Broedel (coords.). Controvérsias Jurídico-Contábeis (aproximações e distanciamentos). São Paulo, Dialética, 2010. p. 71.

${ }^{222}$ As empresas européias com ações listadas em Bolsa de Valores já estão, desde 2005, obrigadas a apresentar suas demonstrações contábeis consolidadas de acordo com as normas do IASB. Ademais, o IASB e o FASB estão trabalhando conjuntamente para harmonização de suas regras contábeis. Por fim, nos Estados Unidos da América, a SEC (Secutities and Exchange Comission - equivalente a nossa CVM) já admite as normas internacionais para as empresas estrangeiras listadas nas bolsas estadunidenses.

223 "Como objeto cultural, a contabilidade pode ser abordada por diversos pontos de vistas teóricos que aportam critérios científicos para adequada explicação dos fenômenos contábeis." (ANDRADE FILHO, Edmar Oliveira. $O$ direito contábil e a disciplina jurídica das demonstrações financeiras. São Paulo: Prognose Editora, 2010. p. 9)
} 
avaliação dos valores de saída (representativo dos benefícios que a empresa auferiu, aufere ou auferirá com a realização de seus recursos, isto é, sua disponibilização no mercado ${ }^{224}$ ).

Durante muitos anos, os contabilistas desenvolveram diversas formas de avaliação dos valores de saída, merecendo destaque:

(i) valor realizado (VR);

(ii) valor corrente de venda (VCV);

(iii) valor realizável líquido (VRL);

(iv) valor de liquidação (VL);

(v) valor de realização futuro (VRF); e

(vi) valor presente do fluxo futuro de caixa ou valor presente líquido (VPL) ${ }^{225}$.

Fiquemos, na presente exposição, apenas com a primeira (VR) e a última (VPL) formas de registro contábeis, as quais, por serem exemplos extremos, serão suficientes para demonstrarmos a evolução da contabilidade e seu maior compromisso em servir de instrumento para tomada de decisões dos usuários, tendo em vista o information approach de que falamos no item precedente.

Pelo VR, as receitas são reconhecidas pelo valor histórico, quer dizer, pelo valor de face efetivamente praticado entre comprador e vendedor, independentemente de outras circunstâncias como o prazo de recebimento efetivo pela venda ou do pagamento pelo estoque adquirido. Essa forma tem as vantagens da objetividade e da praticabilidade, além de, evitando apuração e distribuição antecipadas de lucros potenciais, minimizar o risco de descapitalização da entidade. Por outro lado, o VR sofre críticas no que se refere à utilidade da informação. Isso porque, segundo Eliseu Martins e et. al., oculta as expectativas de geração de riqueza associadas às decisões tomadas, dificulta a avaliação do desempenho e afasta o valor econômico do empreendimento ${ }^{226}$.

Por outro lado, o VPL consiste em converter os benefícios e sacrifícios associados a um item patrimonial em quantidade de moeda, respeitando as épocas de ocorrência e transportá-las para a data específica por meio do uso de taxas de juros ${ }^{227}$.

Para que a noção do VPL fique mais clara e que se possa confrontá-lo com o VR, adotaremos o seguinte exemplo adaptado de Eliseu Martins e et. al. ${ }^{228}$ : dada empresa

${ }^{224}$ Cf. MARTINS, Eliseu; et al. Valores de Saída e Goodwill. In: Avaliação de empresas: da mensuração contábil à econômica. Eliseu Martins (coord.). 1. ed. 6. reimpr. São Paulo: Atlas, 2009. p. 95.

${ }^{225}$ Cf. MARTINS, Eliseu; et al. Valores de Saída e Goodwill. In: Avaliação de empresas: da mensuração contábil à econômica. Eliseu Martins (coord.). 1. ed. 6. reimpr. São Paulo: Atlas, 2009. p. 95.

${ }^{226}$ Cf. MARTINS, Eliseu; et al. Valores de Saída e Goodwill. In: Avaliação de empresas: da mensuração contábil à econômica. Eliseu Martins (coord.). 1. ed. 6. reimpr. São Paulo: Atlas, 2009. p. 97.

${ }^{227}$ Cf. MARTINS, Eliseu; et al. Valores de Saída e Goodwill. In: Avaliação de empresas: da mensuração contábil à econômica. Eliseu Martins (coord.). 1. ed. 6. reimpr. São Paulo: Atlas, 2009. p. 112. 
compra estoques no valor de $\$ 1.000$, sendo $\$ 500$ à vista e o restante para pagamento em 60 dias. Na mesma data, ocorre a venda desses estoques por $\$ 1.200$, com recebimento previsto para 30 dias. A taxa de juros prevista para os dois meses é de $5 \%$ ao mês.

Adotando-se o VR e considerando que, antes dessas operações, a empresa tinha em seu ativo $\$ 500$ de caixa e $\$ 500$ de capital social, teríamos:

\begin{tabular}{|l|r|r|r|}
\hline VR = Valor Realizado & Momento 0 & Momento 1 & Momento 2 \\
\hline Caixa & 0 & 1.200 & 700 \\
\hline Duplicatas a Receber & 1.200 & 0 & 0 \\
\hline Total do Ativo & $\mathbf{1 . 2 0 0}$ & $\mathbf{1 . 2 0 0}$ & $\mathbf{7 0 0}$ \\
\hline Fornecedores & 500 & 500 & 0 \\
\hline Total do Passivo & $\mathbf{5 0 0}$ & $\mathbf{5 0 0}$ & $\mathbf{0}$ \\
\hline Capital Social & 500 & 500 & 500 \\
\hline Lucro & 200 & 200 & 200 \\
\hline Total do Patrimônio Líquido & $\mathbf{7 0 0}$ & $\mathbf{7 0 0}$ & $\mathbf{7 0 0}$ \\
\hline Total do Passivo + Patrimônio Líquido & $\mathbf{1 . 2 0 0}$ & $\mathbf{1 . 2 0 0}$ & $\mathbf{7 0 0}$ \\
\hline
\end{tabular}

Onde:

Momento 0 = aquisição de estoques (metade à vista e metade a prazo) e venda da mercadoria a prazo.

Momento 1 (30 dias após $)$ = data do recebimento efetivo pela venda.

Momento 2 (60 dias após $)=$ data do efetivo pagamento aos fornecedores.

Adotando-se as mesmas premissas, para o VPL, teríamos:

\begin{tabular}{|l|r|r|r|}
\hline $\begin{array}{l}\text { VPL = Valor Presente do Fluxo Futuro } \\
\text { de Caixa ou Valor Presente Líquido }\end{array}$ & Momento 0 & Momento 1 & Momento 2 \\
\hline Caixa & 0 & 1.200 & 700 \\
\hline Duplicatas a Receber & 1.143 & 0 & 0 \\
\hline Total do Ativo & $\mathbf{1 . 1 4 3}$ & $\mathbf{1 . 2 0 0}$ & $\mathbf{7 0 0}$ \\
\hline Fornecedores & 454 & 476 & 0 \\
\hline
\end{tabular}

${ }^{228}$ Cf. MARTINS, Eliseu; et al. Valores de Saída e Goodwill. In: Avaliação de empresas: da mensuração contábil à econômica. Eliseu Martins (coord.). 1. ed. 6. reimpr. São Paulo: Atlas, 2009. p. 114 e ss. 


\begin{tabular}{|l|r|r|r|}
\hline Total do Passivo & $\mathbf{4 5 4}$ & $\mathbf{4 7 6}$ & $\mathbf{0}$ \\
\hline Capital Social & 500 & 500 & 500 \\
\hline Lucro & 189 & 224 & 200 \\
\hline Total do Patrimônio Líquido & $\mathbf{5 8 9}$ & $\mathbf{7 2 4}$ & $\mathbf{7 0 0}$ \\
\hline Total do Passivo + Patrimônio Líquido & $\mathbf{1 . 1 4 3}$ & $\mathbf{1 . 2 0 0}$ & $\mathbf{7 0 0}$ \\
\hline
\end{tabular}

O montante de Duplicatas a Receber, no momento 0, está mensurado a valor presente, descontada a taxa de juros no período de 30 dias $(\$ 1.200 / 1,05=\$ 1.143)$. Da mesma forma, o montante de Fornecedores no momento $0(\$ 500 / 1,1=\$ 454)$ e no momento $1(\$ 500 / 1,05=\$ 476)$. Em face disso, o lucro, que pelo VR se mantém constante em \$200 nos três momentos, no VPL, varia entre \$189 (momento 0), \$224 (momento 1) e, finalmente, \$200 (momento 2).

Para Eliseu Martins e et. al., a despeito de o VPL ter algumas desvantagens (como a ausência de objetividade e de praticabilidade), representa ele um instrumental com maior gama de informações, "estando num dos mais elevados níveis de atendimento ao conceito de utilidade"229. Para eles:

“(...) o valor presente do fluxo futuro de caixa, por melhorar as previsões sobre as futuras entradas e saídas de disponibilidades e mostrar os genuínos elementos patrimoniais geradores de riqueza, possui muitos usos. Um deles seria na avaliação de desempenho dos gestores, em momentos bem antecedentes aos tradicionalmente utilizados para fins dessa verificação de performance.",230

Dessa exposição, é possível perceber que a representação gráfico-contábil do lucro, sob a perspectiva da informação (information aproach), está direcionada para amparar o usuário no mister de tomar decisões prospectivas, auxiliando-o na previsão sobre a geração futura de caixa ou equivalentes. E isso se faz ainda que em detrimento da representação do lucro enquanto fluxo físico de caixa ou equivalente. Isso é plenamente perceptível nos momentos 0 e 1 , no qual a contabilidade apurou lucro diferente de $\$ 200$ (perspectiva de fluxo "físico" de caixa ou equivalente). A representação gráfico-contábil do lucro, nos moldes do VPL, variará nos diferentes momentos para bem informar o usuário sobre a forma como os administradores gerenciam as atividades da entidade. Aliás,

\footnotetext{
${ }^{229}$ MARTINS, Eliseu; et al. Valores de Saída e Goodwill. In: Avaliação de empresas: da mensuração contábil à econômica. Eliseu Martins (coord.). 1. ed. 6. reimpr. São Paulo: Atlas, 2009. p. 118.

${ }^{230}$ MARTINS, Eliseu; et al. Valores de Saída e Goodwill. In: Avaliação de empresas: da mensuração contábil à econômica. Eliseu Martins (coord.). 1. ed. 6. reimpr. São Paulo: Atlas, 2009. p. 118.
} 
dificilmente o lucro contábil na perspectiva da informação se equivalerá ao fluxo físico de caixa, salvo na hipótese de se considerarem limitados números de operações (como no nosso exemplo). Porém, como já se disse, a identificação do lucro enquanto fluxo físico de caixa não é o propósito da contabilidade: o objetivo da contabilidade consiste em nortear seus usuários quanto à tomada de decisões prospectivas, sendo instrumento que possibilite prever a geração de caixa futuro.

Queremos significar com essa exposição que, dentre as diversas alternativas existentes e desenvolvidas pelos cientistas contábeis, a contabilidade tem meios para apresentar um relatório com vistas à tomada de decisões dos usuários, numa visão prospectiva. Pretendemos deixar claro que a contabilidade, mesmo podendo optar pela apresentação de meros eventos ocorridos no passado (como no método do valor realizado), vai além, sempre tendo como princípio melhor apresentar informações aos usuários.

Entre retratar simplesmente aquilo que ocorreu no passado e expor um relatório mais útil para seus usuários tomarem decisões, a contabilidade optou pela segunda alternativa. Tem, destarte, seus olhos voltados para o futuro - e não para o passado.

Essa constatação é de extrema importância para atingirmos nossos objetivos: cotejar a renda constitucionalmente tributável e o lucro contábil. Como demonstramos no capítulo 3, a tributação deve alcançar apenas o êxito já alcançado (até o presente), sob pena de inobservância de função bloqueadora do princípio da capacidade contributiva. Por outro lado, visto que a representação de lucro fornecida pela contabilidade não tem compromisso com esse propósito, é natural que se cause no observador a sensação de que há incompatibilidade entre essas duas realidades, devendo, pois, o legislador tributário adotar medidas que eliminem ou mitiguem possíveis incompatibilidades, se quiser adotar o lucro contábil como ponto de partida para apuração da base de cálculo do IRPJ. Exploraremos esse ponto no último capítulo do presente trabalho. 


\subsubsection{O LUCRO E SUA MANIPULAÇÃO PELA CIÊNCIA CONTÁBIL}

\subsubsection{BREVES ANOTAÇÕES SOBRE A EVOLUÇÃO DAS DIFERENTES PERSPECTIVAS DE LUCRO EM TEORIA DA CONTABILIDADE}

As considerações sobre o que se deva entender e como representar o lucro é tema que sempre preocupou os estudiosos da Teoria da Contabilidade, tendo havido, ao longo dos tempos, uma evolução desse conceito, dadas a utilidade da informação contábil e as necessidades dos usuários da contabilidade.

Pois bem. Nos primórdios da contabilidade, o lucro era concebido como simples acréscimo de caixa no médio e longo prazo $^{231}$. Tratava-se de modelo contábil baseado no valor histórico das transações, fluxo físico de caixa e sem qualquer nível de sofisticação ${ }^{232}$, muito embora atendesse certas necessidades dos usuários da contabilidade no contexto social em que inserido.

Com a evolução dos mercados e do nível de informação a ser fornecida para os usuários, particularmente após a revolução industrial, percebeu-se que um modelo baseado apenas no fluxo físico de caixa não era mais capaz de refletir o desempenho da atividade (vale dizer, o efetivo resultado). Isso porque o preciso momento de entrada ou saída de caixa estava muitas vezes desconexo com o momento da geração da riqueza ou decréscimo patrimonial $^{233}$. Destarte, com a evolução da técnica contábil, desenvolveu-se o que chamamos hoje de regime de competência, nascido da necessidade de compartilhamento temporal entre entradas e saídas de caixa, como medida para melhor retratar o desempenho da atividade.

\footnotetext{
${ }^{231}$ Cf. COELHO, Cláudio Ulysses Ferreira; LINS, Luiz dos Santos. Teoria da Contabilidade. Abordagem Contextual, Histórica e Gerencial. São Paulo: Atlas, 2010. ps. 211 e 212.

${ }^{232}$ Cf. MARTINS, Eliseu. Ensaio sobre a Evolução do Uso e das Características do Valor Justo. In: MOSQUERA, Roberto Quiroga. LOPES, Alexsandro Broedel (coords.). Controvérsias Jurídico-Contábeis (aproximações e distanciamentos). São Paulo, Dialética, 2010. p. 138.

${ }^{233}$ Eliseu Martins nos ensina que "Mas os movimentos físicos de caixa, em períodos pequenos, não evidenciam claramente a existência ou não de lucro e sua medida; num mesmo mês, por exemplo, pode entrar caixa por venda do próprio mês, de meses anteriores ou por conta de mercadoria a entregar que sequer tinha sido adquirida; e também pode sair caixa por conta de mercadoria ainda não vendida, vendida no mês anterior, roubada etc." (Ensaio sobre a Evolução do Uso e das Características do Valor Justo. In: MOSQUERA, Roberto Quiroga. LOPES, Alexsandro Broedel (coords.). Controvérsias Jurídico-Contábeis (aproximações e distanciamentos). São Paulo, Dialética, 2010. p. 138.)
} 
Veja-se, portanto, que a noção de lucro contábil evoluiu de um modelo que levava em consideração tão somente o fluxo "desordenado" de entrada e saída de caixa para outro modelo em que essas entradas e saídas deveriam ser "casadas" para fins de demonstração do lucro.

Ademais, é importante frisar que os economistas deram grande contribuição para a construção da noção de lucro contábil. Adam Smith, de maneira inovadora, definiu lucro como o montante que poderia ser consumido sem reduzir o capital. O economista inglês e ganhador do Prêmio Nobel, Sir John Hicks, aprofundou essa ideia, assumindo que o lucro seria o montante que uma pessoa pode gastar durante um período e ainda estar tão bem ao final do período quanto no início. Em suma, o lucro, a partir dos estudos desses economistas, seria o excedente após a manutenção do bem-estar, mas antes do consumo ${ }^{234}$.

Com efeito, o conceito de lucro enquanto montante consumível sem prejuízo da capitalização da entidade é, portanto, a origem para o desenvolvimento de técnicas de representação do lucro contábil, como as atualmente praticadas e difundidas depreciação de ativos e constituição de provisões. Tais medidas são adotadas para que as entidades não distribuam lucros (e, por consequência, descapitalizem-se) sem levar em conta recursos necessários para continuidade a médio e longo prazo da atividade (recursos necessários para aquisição de novos ativos fixos ou para cobrir saídas de caixa iminentes).

Essa noção de lucro é muito próximo daquilo que os Professores Hendriksen e Van Breda chamam de perspectiva sintática do lucro, isto é, uma perspectiva que dá enfoque às transações perpetradas pela entidade. De toda forma, esses estudiosos chamam a atenção para a perspectiva semântica do lucro contábil, ou seja, o lucro contábil como instrumento para análise da eficiência da entidade. Nesse sentido, haveria uma comparação com o que eventualmente se poderia ganhar com outro investimento, assumindo-se um caráter mais econômico, vinculado a uma ideia de custo de oportunidade ${ }^{235}$.

\footnotetext{
${ }^{234}$ HENDRIKSEN, Eldon S.; BREDA, Michael F. Van. Teoria da Contabilidade. 1. ed. 8. reimpr. Tradução de Antonio Zoratto Sanvicente. São Paulo: Atlas, 2010. p. 183.

${ }^{235}$ Cf. COELHO, Cláudio Ulysses Ferreira; LINS, Luiz dos Santos. Teoria da Contabilidade. Abordagem Contextual, Histórica e Gerencial. São Paulo: Atlas, 2010. ps. 211.
} 


\subsubsection{FLUXOS FÍSICOS DE CAIXA E NECESSIDADE DE REPRENTAÇÃO GRÁFICA DE LUCRO (O LUCRO CONTÁBIL)}

Afinal de contas, o que é lucro?

Para melhor esclarecer essa questão, Veron Kam, em seu "Accounting Theory", examina duas situações extremas: uma o que ele denomina de terminal case e outra, certainty of future case.

A diferença entre ambas é que a primeira é uma entidade de pouquíssimas operações e de vida curta. Assim, a determinação de lucro dessa primeira entidade não demandaria maiores reflexões ou esforços, sendo verificável por meio de uma simples apuração de fluxo físico de caixa.

Adaptando o exemplo apontado pelo teórico em sua obra, teríamos:

\begin{tabular}{|l|r|r|r|}
\hline & Momento 0 & Momento 1 & Momento 2 \\
\hline Caixa & - & - & 1.900 \\
\hline Mercadorias & 1.000 & - & - \\
\hline Duplicatas a Receber & - & 2.000 & - \\
\hline Ativo Fixo & 1.000 & 1.000 & $\mathbf{1 . 9 0 0}$ \\
\hline Total do Ativo & $\mathbf{2 . 0 0 0}$ & $\mathbf{3 . 0 0 0}$ & - \\
\hline Fornecedores & 1.000 & 1.000 & - \\
\hline Total do Passivo & $\mathbf{1 . 0 0 0}$ & $\mathbf{1 . 0 0 0}$ & 1.000 \\
\hline Capital Social & 1.000 & 1.000 & 900 \\
\hline Lucro & - & 1.000 & $\mathbf{1 . 9 0 0}$ \\
\hline Total do Patrimônio Líquido & $\mathbf{1 . 0 0 0}$ & $\mathbf{2 . 0 0 0}$ & $\mathbf{1 . 9 0 0}$ \\
\hline Total do Passivo + Patrimônio Líquido & $\mathbf{2 . 0 0 0}$ & $\mathbf{3 . 0 0 0}$ & \\
\hline
\end{tabular}

onde:

Momento $0=$ Aporte de capital de $\$ 1.000$, aquisição de mercadorias à vista por $\$ 1.000$ e aquisição a prazo de ativos fixos no valor de $\$ 1.000$.

Momento 1 = venda a prazo das mercadorias por $\$ 2.000$.

Momento 2 = Recebimento do cliente (\$2.000), pagamento de fornecedores (\$1.000) e venda do ativo fixo por $\$ 900$. 
Percebe-se que, nesse simples exemplo, tudo foi reduzido a caixa, sendo facilmente verificável que o lucro do empreendimento foi de $\$ 900$ (venda das mercadorias por $\$ 1.000$ a mais do que o custo + venda do ativo fixo por $\$ 100$ a menos do que o custo). Como o investimento foi devolvido para os sócios $(\$ 1.000$ do investimento inicial $+\$ 900$ de lucro = saldo de $\$ 1.900$ em caixa), podemos dizer que o lucro pôde ser constatável pelo simples fluxo físico de caixa da entidade. Nas palavras do teórico:

"We see in this first example that eventually income must be cash. When the firm has no future, it is possible to equale revenues with the cash receipts and expenses with the cash payments because everything in the end reduces to cash." 236

Em suma, nesse raro e hipotético exemplo, o lucro foi igual ao saldo final do fluxo físico de caixa.

Ocorre, todavia, que esse exemplo não pode ser tomado como regra na grande maioria dos empreendimentos empresariais. Isso porque, sendo de vida útil indeterminada, as entidades detêm recebíveis e obrigações não realizados (i.e., não reduzidos a caixa) e, via de consequência, o fluxo físico de caixa não equivaleria ao efetivo lucro.

Daí a necessidade do desenvolvimento de modelos para a apresentação e representação contábil do lucro, já que, nas situações em que as entidades têm vida útil indefinida (e nem todos os recebíveis e obrigações são reduzidos à caixa), não há que se falar em fluxo final de caixa e, em última análise, em lucro. Destarte, Veron Kam sentencia: "Accruals and deferrals are important only when the life of the firm is long or its terminal date is unknown, and information about income is desired before the firm's expiration." 237

Com efeito, o que pretendemos demonstrar por ocasião deste item é que a noção de lucro está longe de ser uma simples apuração do fluxo físico de caixa (entradas e saídas de caixa), eis que, na grande maioria dos casos, as entidades têm vida útil indeterminada. Por conta disso, ao longo dos tempos, foram desenvolvidos pelos estudiosos da Teoria da Contabilidade diversos métodos capazes de representar (ou prever) esse fluxo físico de caixa (e, em última análise, o lucro) das entidades.

Assim, algumas conclusões podem ser extraídas do item presente:

(i) o lucro pode ser tomado como saldo final de fluxo físico de caixa (entradas e saídas de caixa);

\footnotetext{
${ }^{236}$ KAM, Vernon. Accounting Theory. 2a ed. New York: John Wiley and Sons, s/d. p. 188.
}

${ }^{237}$ KAM, Vernon. Accounting Theory. 2a ed. New York: John Wiley and Sons, s/d. p. 193. 
(ii) porém, como as entidades empresariais têm vida útil indeterminada, não se pode ter certeza desse "saldo final de fluxo físico de caixa" (e, em última análise, do próprio lucro) antes do encerramento definitivo das atividades da entidade;

(iii) como forma de melhor representar ou prever o "saldo final de fluxo físico de caixa", os estudiosos da Teoria da Contabilidade desenvolveram diversas técnicas, as quais, todavia, não são uniformes ao longo dos tempos e lugares e, pode-se dizer, sempre serão alvo de continuo desenvolvimento.

Cabe destacar, por fim, que Eliseu Martins, sobre as diversas técnicas contábeis desenvolvidas ao longo dos tempos, destaca oportunamente que são:

“(...) nada mais nada menos do que distribuições temporais diferentes do mesmíssimo fluxo físico de caixa. Assim, no longo prazo, são todos convergentes para um único valor de lucro, com dois únicos fatores a produzir resultados diferentes: a consideração ou não dos efeitos da inflação e a consideração ou não do custo de oportunidade do capital próprio." 238

Portanto, mais uma conclusão importante para a continuidade de nossos trabalhos: salvo nos casos de realização de todos os recebíveis e obrigações, o lucro apontado pela contabilidade é resultado de uma construção humana (abstração humana), passível de contínuo desenvolvimento científico, sendo uma representação (ou tentativa de previsão) do fluxo físico de caixa esperado da entidade. Se assim é, especialmente para os leigos em ciências contábeis, deve ser desmistificada a ideia de que o lucro contábil é perfeita e inabalável representação de "superávit”, "ganhos” ou "vantagens" experimentados pelos investidores. Em nossa visão, é mais apropriado falar em lucro contábil enquanto representação gráfica, continuamente manipulável por convenções científicas, de expectativas de fluxo físico de caixa esperado da entidade.

\subsubsection{DEMONSTRAÇÃO DO RESULTADO DO EXERCÍCIO E DEMONSTRAÇÃO DO RESULTADO ABRANGENTE}

Conforme se pôde extrair alhures, a noção de lucro é manipulável pela ciência contábil, de modo a atender aos propósitos perseguidos pelos usuários da contabilidade. Noutros termos, a contabilidade não pode ser concebida como a ciência que "descobre" um

${ }^{238}$ MARTINS, Eliseu (coord.). Avaliação de empresas: da mensuração contábil à econômica. 1. ed. 6. reimpr. São Paulo: Atlas, 2009. p. 12. 
lucro naturalmente existente, mas sim a ciência que "constrói" o lucro a partir de métodos desenvolvidos por estudiosos e admitidos pela comunidade contábil.

Atestando a procedência de nossa assertiva, basta-nos passar os olhos na evolução lucro contábil ao longo dos tempos, conforme breve exposição acima. Se, antes da revolução industrial, a noção de lucro estava intensamente atrelada ao fluxo físico de caixa, a contabilidade evoluiu para passar a acolher a noção do que hoje entendemos por regime de competência, registrando situações que não significavam imediatamente movimentações no caixa, como depreciações e provisões ${ }^{239}$.

Até mesmo no que tange à contabilidade societária vigente atualmente no Brasil (a qual será melhor explorada no item 5.2), o lucro é apresentado de duas maneiras distintas: uma por meio da tradicional DRE, que serve de suporte para distribuição de dividendos e ponto de partida para apuração do IRPJ, e outra por meio da DRA.

A DRA, obrigatória nos termos da CPC 26, abriga não apenas os itens da tradicional DRE, mas também as demais variações do patrimônio líquido, que poderão transitar no futuro pelo resultado do período ou irem direto para Lucros ou Prejuízos Acumulados (por exemplo, ativos financeiros avaliados a valor justo, mas destinados à venda futura). E assim, por meio da DRA, a contabilidade cumpre sua função de prover os usuários de informações sobre as atividades das entidades.

De toda forma, quer-nos parecer que a DRA não substituiu a DRE como índice para distribuição de dividendos ou como ponto de partida para apuração do IRPJ. Trata-se, a DRA, de relatório contábil subsidiário, fruto de determinados ajustes no DRE, servindo apenas para melhor oferecer informações ao usuário da contabilidade.

Ademais, a DRE é expressamente regulamentada pela LSA, não podendo ser substituída pela DRA como ponto de partida da apuração do IRPJ, eis que esta última encontra fundamento em norma infralegal. Sobre a prevalência da DRE, para fins de apuração do IRPJ, sob a perspectiva do princípio da legalidade tributária e a regulamentação de preceitos contábeis por autoridades não integrantes do Poder Legislativo, vide o item 5.3.4., a seguir.

${ }^{239}$ Cf. COELHO, Cláudio Ulysses Ferreira; LINS, Luiz dos Santos. Teoria da Contabilidade. Abordagem Contextual, Histórica e Gerencial. São Paulo: Atlas, 2010. p. 212. 


\subsubsection{COMPREENSÃO TEÓRICA DA CONTABILIDADE}

\subsubsection{A CONTABILIDADE ENQUANTO DESTRUIÇÃO E RECONSTRUÇÃO DA REALIDADE}

Aquilo que comumente se chama de realidade é, para o filófoso theco Vilém Flusser, apenas um dado bruto, próximo do intelecto, porém, intangível para o homem. Os dados brutos não representam realidade, mas apenas potencialidade de realidade. Vale dizer, os dados brutos não se realizam (não se tornam realidade) senão por meio da linguagem. Exatamente por isso, a realidade não pode ser concebida como a correspondência entre a frase e o dado bruto (reitere-se: este último é inatingível). A realidade é, portanto, a correspondência entre frases, resultados das regras da língua.

Assim, se a realidade é tão dependente da língua, natural que se vislumbre que, trocando de língua, troca-se de realidade ${ }^{240}$. Decorrência disso, quando se fala no processo de tradução, não se pode concebê-lo como reflexo idêntico, quase um espelho entre o conteúdo da língua traduzida para uma outra língua. A rigor, para Vilém Flusser, a tradução nessa acepção é impossível. Conclui o autor que a tradução é possível apenas aproximadamente, graças às semelhanças existentes entre as línguas, semelhanças ontológicas $^{241}$.

O autor exemplifica seu pensamento a partir da tradução de vou (português) para I go (inglês):

"O papel, isto é, o significado, da frase vou dentro do sistema português, é, portanto, semelhante ao papel, ao significado da frase $I$ go dentro do sistema inglês. A tradução é, pois, aproximadamente legítima. Nossa resposta é mais laboriosa, mas tem a vantagem de ser mais certa. É fácil demonstrar que a resposta clássica é falsa. Basta ampliar a frase. Vou estudar não pode ser traduzido por I go learn. O significado de vou não é, portanto, idêntico ao

\footnotetext{
${ }^{240}$ Sintetizando tudo isso, Vilém Flusser explica por meio da seguinte metáfora: "A imagem que se oferece é a seguinte: a realidade, este conjunto de dados brutos, está lá, dada e brutal, próxima do intelecto, mas inatingível. Este, o intelecto, dispõe de uma coleção de óculos, das diversas línguas, para observá-la. Toda vez que troca de óculos, a realidade 'parece ser' diferente. A dificuldade dessa imagem reside na expressão 'parece ser'. Para ser, a realidade precisa parecer. Portanto, toda vez que o intelecto troca de língua, a realidade é diferente." (FLUSSER, Vilém. Língua e Realidade. 2.ed. São Paulo: Annablume, 2004. p. 52 e 53.)

${ }^{241}$ Cf. FLUSSER, Vilém. Língua e Realidade. 2.ed. São Paulo: Annablume, 2004. p. 61.
} 
significado de $I$ go. Em português, vou tem um significado de verbo auxiliar, que o inglês I go não tem, ou se o tem, é em grau muito mais fraco.",242

A tradução deve ser concebida, com efeito, como uma destruição e um renascimento do intelecto ${ }^{243}$. Noutros dizeres, a tradução é um processo por meio do qual se destrói a realidade construída pela primeira língua (o intelecto) para, posteriormente, reconstruí-la numa segunda língua.

Parece-nos que, mutatis mutandis, situação semelhante ocorre com a contabilidade. Melhor esclarecendo a idéia, assim como na tradução ordinária, o tradutorcontabilista destrói a realidade construída pela linguagem jurídica (compra e venda de mercadorias, arrendamento mercantil, aumento de capital, mútuos, distribuição de dividendos, etc.) para (re)construir a de outra (linguagem contábil). O contabilista tem a função de traduzir para seu idioma (a linguagem científica da contabilidade) os fatos jurídicos com conteúdo patrimonial. Ele nada mais é do que um tradutor (ou melhor, um intérprete) da linguagem contábil.

Assim, saliente-se que, nesse processo de tradução, é constituída pela contabilidade uma nova realidade destoante da realidade primitiva. Essa noção não passou despercebida por Edvaldo Brito, reconhecendo haver distorções que a linguagem contábil pode causar na tradução da realidade jurídica:

"Nesse ponto, então, vale distinguir a linguagem da contabilidade e a do direito, a fim de constatar por que a primeira pode propiciar distorções. A linguagem da contabilidade é formalizada, como são a da Matemática e a da Lógica. A do Direito é técnica. Diz-se que é formalizada porque, em lugar das palavras da língua natural que tenham conteúdos semânticos capazes de referenciarem situações concretas do mundo, colocam-se símbolos aptos para recolherem qualquer coisa ou situação concreta de qualquer universo."244

“(...) as formalizações contábeis não o exprimem [o patrimônio e seus acréscimos], até porque, em regra, elas são simbolizações de ficções,

\footnotetext{
${ }^{242}$ FLUSSER, Vilém. Língua e Realidade. 2.ed. São Paulo: Annablume, 2004. p. 57.

${ }^{243}$ Cf. FLUSSER, Vilém. Língua e Realidade. 2.ed. São Paulo: Annablume, 2004. p. 82.

244 BRITO, Edvaldo. O excesso de retirada tributável como acréscimo patrimonial. In: MARTINS, Ives Gandra da Silva (Coord.). Imposto de Renda: conceitos, princípios, comentários. 2.ed. São Paulo: Atlas, 1996. p. 112.
} 
juridicamente, incabíveis ou de praesumptio hominis - tão incabível quanto... e eis o surgimento das distorções." 245

As distorções entre as realidades contábil e jurídica podem ocorrer com maior intensidade, eis que tradutor-contabilista (ao contrário do tradutor ordinário) não tem maiores compromissos com a preservação da realidade da primeira linguagem. Poderá ele manipular essa realidade, de maneira a garantir que a contabilidade sirva de instrumento para decisões de seus usuários, nos moldes de que tratamos nos itens precedentes. Isso porque, parafraseando Roberto Quiroga Mosquera e Alexsandro Broedel Lopes, “o processo contábil possui uma lente própria - com seus usos, métodos e costumes - para enxergar a realidade e retratá-la nas demonstrações contábeis."246

Uma peculiaridade nesse processo de tradução-contabilização consiste na circunstância de que determinados fatos contábeis não têm suporte em fatos jurídicos, como ocorre com algumas provisões.

Por tudo o quanto foi exposto, somos de opinião de que a contabilidade não é como podem imaginar alguns - mera técnica de mensuração e avaliação do patrimônio, na acepção jurídica de que cuidamos no item 3.2.3 (Breves Considerações sobre o Patrimônio). A contabilidade, diante de fatos jurídicos com conteúdo patrimonial, traduz essa realidade para a sua própria linguagem. Reitere-se: destrói a realidade da linguagem jurídica para reconstruir essa realidade para sua própria linguagem.

\subsubsection{A FALÁCIA DA FIEL DEMONSTRAÇÃO DO PATRIMÔNIO (NA ACEPÇÃO JURÍDICA)}

No Brasil, em razão de determinação da CVM, há algumas décadas, para que as operações de arrendamento mercantil fossem contabilizadas à semelhança dos contratos de financiamento, os juristas se rebelaram contra a "liberação" da contabilidade dos vínculos jurídicos, justificando que isso nada mais representaria que um movimento reivindicatório dos contabilistas em face da posição subalterna da qual muitos economistas e juristas conceberiam a profissão contábil. Em essência, alguns juristas pregavam que a

\footnotetext{
${ }^{245}$ BRITO, Edvaldo. O excesso de retirada tributável como acréscimo patrimonial. In: MARTINS, Ives Gandra da Silva (Coord.). Imposto de Renda: conceitos, princípios, comentários. 2.ed. São Paulo: Atlas, 1996. p. 118. Grifos do autor.

${ }^{246}$ MOSQUERA, Roberto Quiroga; LOPES, Alexsandro Broedel. O Direito Contábil - Fundamentos Conceituais, Aspectos da Experiência Brasileira e Implicações. In: MOSQUERA, Roberto Quiroga. LOPES, Alexsandro Broedel (coords.). Controvérsias Jurídico-Contábeis (aproximações e distanciamentos). São Paulo, Dialética, 2010. p. 59.
} 
contabilidade deveria retratar a realidade jurídica, sob pena de não fazer refletir a situação patrimonial da entidade.

Todavia, segundo pensamos, assim não deve ser concebida a contabilidade.

Retratar a realidade jurídica, além de não ser possível, afastaria a contabilidade de sua atual perspectiva (information approach). Se assim fosse, a contabilidade perderia sua função de servir de instrumento para que seus usuários possam tomar decisões prospectivas, baseando-se na previsão de fluxos de caixa futuro.

Visto dessa maneira, percebe-se que a contabilidade não está adstrita - e nem poderia estar - a ser fiel e indissociável reflexo do patrimônio das companhias, assim entendido em sua acepção estritamente jurídica. Formulando de outra maneira, ainda que a contabilidade pudesse ser preciso reflexo da universalidade de relações jurídicas das companhias - o que não acreditamos, eis que a "tradução" consiste na reconstrução da realidade - os relatórios contábeis podem sim retratar os negócios jurídicos sem captar influências do regime jurídico afetos a eles, desde que em conformidade com as finalidades da contabilidade, particularmente na atual perspectiva (information approach) $)^{247}$.

A retratação estritamente patrimonial da companhia (na acepção jurídica) levada a efeito pela contabilidade poderia não atender a todos os propósitos, perdendo, via de consequência, sua própria razão de ser. À guisa de exemplo, se levarmos à risca a acepção de patrimônio como complexo de relações jurídicas dos sujeitos de direito, a contabilidade societária não poderia sequer reconhecer provisões para riscos, uma vez que elas se confundem com meras expectativas de deveres jurídicos ${ }^{248}$. E se assim fosse, estaria seriamente ameaçada a missão da contabilidade de servir, v.g., como instrumento de interesse público no controle da distribuição de resultados das companhias.

A confirmar tudo isso, José Luiz Bulhões Pedreira, há algumas décadas, já afirmava que o objeto da escrituração contábil é o patrimônio, porém, em seu conceito

\footnotetext{
247 Portanto, há de se tomar cuidado com a seguinte afirmação de Ricardo Mariz de Oliveira: “(...) a contabilidade está adstrita a enxergar os acontecimentos econômicos com os olhos do direito." (OLIVEIRA, Ricardo Mariz de. Fundamentos do Imposto de Renda. São Paulo: Quartier Latin, 2008. p. 1.017) Logo em seguida, o autor flexibiliza, na página 1.021, tal afirmação com os seguintes dizeres: “(...) embora o conceito contábil seja substancialmente igual ao jurídico, há situações em que os contabilistas adotam uma postura diferente, porque levam em conta situações ou considerações econômicas que devem entrar na demonstração patrimonial por razões gerenciais, ou de informação ao público, ou ainda para atender exigências do mercado de capitais ou outras razões negociais, inclusive muitas vezes tendo que seguir exigências de órgãos regulatórios.".

${ }^{248}$ Para melhor compreensão das provisões, Nilton Latorraca comenta: "Assim, por exemplo, se a companhia é parte de uma demanda judicial, cujo andamento do processo antecipa pouquíssimas possibilidades em seu favor, é obrigação da administração determinar que se registre contabilmente o encargo (redução do lucro), que constitui uma perda provável, ou, se quisermos, um risco calculável.” (In: MODESTO, Carvalhosa. Comentários à Lei de Sociedades Anônimas. 3.vol. São Paulo: Saraiva, 2003. p. 721.)
} 
financeiro. Para ele, "o conceito financeiro de patrimônio não considera esse conjunto de direitos e obrigações na sua natureza jurídica, mas na sua função de mecanismo de organização da atividade econômica social."249

E mais. Não podemos nos esquecer de que, notadamente a partir das Leis $n^{\circ} \mathrm{s}$. 11.638/07 e 11.941/09, a contabilidade brasileira passou, com mais intensidade, a servir de instrumento para fornecer a investidores estrangeiros elementos hábeis em suas decisões econômicas afetas às companhias brasileiras. As demonstrações financeiras passaram, então, a ter, com mais intensidade, como propósito final o suporte na tomadas de decisões empresariais. Têm elas, portanto, função de balizar análises prospectivas das companhias.

Se assim é, parece-nos que o legislador se convenceu de que, para o usuário que tem de tomar decisões econômicas, a contabilidade seria um instrumento mais eficaz se, v.g., a operação de leaseback fosse retratada como uma operação de financiamento com garantia e não como venda de ativo seguida de arrendamento mercantil ${ }^{250}$; ou se as operações comerciais originárias de recebíveis e exigíveis a longo prazo fossem retratadas, ainda que em parte, como financiamentos. Buscou o legislador um relatório para fins de análises prospectivas e, para tanto, não limitou a contabilidade societária a ser simplesmente fiel espelho do regime jurídico correspondente ao negócio retratado (ainda que isso fosse possível).

Sensibilizado pelas cada vez mais diferenças entre a contabilidade e o direito, Ricardo Lacaz Martins assevera: "Enquanto a nova contabilidade atenta para a análise de risco dos negócios praticados, o direito verifica se aquele negócio trouxe ou não repercussão na esfera patrimonial da empresa." 251 Nesse mesmo sentido, Elidie Palma Bifano: “(...) alguns dos princípios que suportam os padrões internacionais de Contabilidade prescindem de quaisquer razões ou fundamentos jurídicos, afastam-se do negócio jurídico e caminham pelo mundo da essência econômica." ${ }^{252}$ Adiante, a autora faz

\footnotetext{
249 PEDREIRA, José Luiz Bulhões. Imposto sobre a Renda - Pessoas Jurídicas. Vol. I. Rio de Janeiro: Justec, 1979. p. 244.

${ }^{250}$ Pronunciamento CPC sobre a Estrutura Conceitual para Elaboração e Apresentação das Demonstrações Contábeis: "Primazia da Essência sobre a Forma 35. (...). Por exemplo, uma entidade pode vender um ativo a um terceiro de tal maneira que a documentação indique a transferência legal da propriedade a esse terceiro; entretanto, poderão existir acordos que assegurem que a entidade continuará a usufruir os futuros benefícios econômicos gerados pelo ativo e o recomprará depois de um certo tempo por um montante que se aproxima do valor original de venda acrescido de juros de mercado durante esse período. Em tais circunstâncias, reportar a venda não representaria adequadamente a transação formalizada."

${ }^{251}$ MARTINS, Ricardo Lacaz. A Tributação da Renda Imobiliária. Tese. Doutorado. Universidade de São Paulo, 2009. p. 94.

${ }^{252}$ BIFANO, Elidie Palma. Contabilidade e direito: a nova relação. In: MOSQUERA, Roberto Quiroga. LOPES, Alexsandro Broedel (coords.). Controvérsias Jurídico-Contábeis (aproximações e distanciamentos). São Paulo, Dialética, 2010. p. 124.
} 
uma afirmação categórica: “(...) a regra jurídica perdeu toda e qualquer importância, não mais se prestando a suportar a escrituração contábil."253

E, sendo dessa forma, a expressão contábil estritamente influenciada pelo regime jurídico do negócio retratado não atenderia, em seu esplendor, as finalidades pretendidas pelo legislador, seja no que diz respeito à prestação de contas e fiscalização da gestão dos administradores, seja no que se refere ao controle de distribuição de resultados da companhia ou, enfim, seja no tocante ao oferecimento de relatórios úteis para inserção das companhias brasileiras nos principais mercados de valores mobiliários.

Exatamente por perseguir propósitos específicos, a contabilidade desvincula-se das influências do regime jurídico, passando a idealizar um sem número de eventos retratados. E assim o fez com compreensiva legitimidade, sob pena de perda de sua própria razão de ser. Portanto, nada impede - e, pelo contrário, muito se aconselha - que haja registro de ativos desvinculados de uma relação jurídica na qual a companhia seja credora se isso for útil para tomadas de decisões econômicas ${ }^{254}$. Da mesma forma, não há óbice para o acolhimento de um passivo que não represente uma obrigação legal devidamente constituída por linguagem jurídica competente ${ }^{255}$.

A contabilidade, ao contrário do que alguns possam imaginar, não deve ser vista apenas como instrumento que quantifica direitos e deveres patrimoniais; em nossa visão, ela idealiza e interpreta os fatos jurídicos à sua específica maneira, de forma a produzir relatórios úteis para análise prospectiva das companhias ${ }^{256}$. Como dissemos acima, trata-se de um processo semelhante à tradução na acepção de Vilém Flusser.

253 BIFANO, Elidie Palma. Contabilidade e direito: a nova relação. In: MOSQUERA, Roberto Quiroga. LOPES, Alexsandro Broedel (coords.). Controvérsias Jurídico-Contábeis (aproximações e distanciamentos). São Paulo, Dialética, 2010. p. 130.

${ }^{254}$ Pronunciamento CPC sobre a Estrutura Conceitual para Elaboração e Apresentação das Demonstrações Contábeis: "57. (...) Embora a capacidade de uma entidade controlar os benefícios econômicos normalmente seja proveniente da existência de direitos legais, um item pode satisfazer a definição de um ativo mesmo quando não há controle legal. (...)."

${ }^{255}$ Pronunciamento CPC sobre a Estrutura Conceitual para Elaboração e Apresentação das Demonstrações Contábeis: “60. (...) Obrigações surgem também de práticas usuais de negócios, usos e costumes e o desejo de manter boas relações comerciais ou agir de maneira eqüitativa. Se, por exemplo, uma entidade decide, por uma questão de política mercadológica ou de imagem, retificar defeitos em seus produtos, mesmo quando tais defeitos tenham se tornado conhecidos depois que expirou o período da garantia, as importâncias que espera gastar com os produtos já vendidos constituem-se passivos."

256 "A contabilidade é, essencialmente, um modelo de alocação de recursos e não de avaliação. (...) A vocação da Contabilidade para não pretender avaliar o valor econômico da entidade é resultado, também, da função que suas informações representam para os tomadores de decisão, principalmente externos à entidade." (IUDÍCIBUS, Sérgio. Essência sobre a forma e o valor justo: duas faces da mesma moeda. In: MOSQUERA, Roberto Quiroga. LOPES, Alexsandro Broedel (coords.). Controvérsias Jurídico-Contábeis (aproximações e distanciamentos). São Paulo, Dialética, 2010. p. 475. 
Por essas razões, ousamos discordar de renomados juristas que não veem razão de ser da contabilidade quando ela faz refletir em suas peças fatos independentes do tratamento jurídico inerente a eles ${ }^{257}$.

\subsubsection{A PRIMAZIA DA ESSÊNCIA ECONÔMICA SOBRE A FORMA JURÍDICA: DISTANCIAMENTO ENTRE DIREITO E CONTABILIDADE}

Vamos além. Baseados nas premissas apontadas nos itens precedentes, causanos certo desconforto a afirmação - algumas vezes peremptória - segundo a qual a contabilidade retrataria fielmente a realidade econômica da empresa, tendo em vista a existência da "primazia da essência (econômica) sobre a forma (jurídica)". Com efeito, poder-se-ia, numa superficial impressão, dar a entender que os contabilistas dominam completamente a ciência econômica e, mais do que isso, podem fazer traduzir a tão divulgada essência econômica para o relatório contábil.

Essa preliminar impressão merece maiores reflexões.

Como visto antes, a tradução de uma linguagem para outra sempre ocorre por aproximação, nunca como reflexo perfeito, um espelho. Sempre se consubstancia um ato de destruição do conteúdo (intelecto) da primeira língua para reconstruir o conteúdo numa segunda. E nesse mister, a contabilidade reconstruirá a realidade à sua maneira - e não necessariamente à maneira da ciência econômica. Daí porque ter irreparável procedência a seguinte advertência de Sérgio de Iudícibus e et. al.: "Informação de natureza econômica deve ser sempre entendida dentro da visão que a Contabilidade tem do que seja econômico e não, necessariamente, do tratamento que a Economia daria ao mesmo fenômeno." ${ }^{258} \mathrm{Em}$ conclusão, a contabilidade não é fiel espelho do direito (como vimos no item precedente) nem da ciência econômica. A contabilidade tem seu próprio objetivo, ligado ao information approach.

\footnotetext{
${ }^{257}$ Discordamos, pois, de Ricardo Mariz de Oliveira quando critica as inovações trazidas pela Lei $\mathrm{n}^{\circ}$ 11.638/07: "Portanto, numa primeira leitura nota-se que o legislador da Lei $n^{\circ} 11638$ percebeu a existência de diferentes fontes de suprimento, mas, atentando-se para suas palavras constata-se que, a despeito disso, colocou todos os ingressos numa só cesta, de 'riqueza gerada pela companhia'. Esta modificação na Lei n. 11638 provavelmente represente a maior falha conceitual contida na Lei n. 11638, ao lado da possibilidade que ela abre de inclusão de direitos ou obrigações inexistentes, ou da exclusão de outros que existam, sem atenção ao patrimônio jurídico da pessoa jurídica." (OLIVEIRA, Ricardo Mariz de. Fundamentos do Imposto de Renda. São Paulo: Quartier Latin, 2008. p. 1.079)

${ }^{258}$ IUDÍCIUS, Sérgio de; GELBCKE, Ernesto Rubens; MARTINS, Eliseu. Manual de Contabilidade das Sociedades por Ações: aplicável às demais sociedades. $6^{\mathrm{a}}$ ed., ver. e atual. São Paulo: Atlas, 2003. p. 49.
} 
Destarte, preferimos conceber a primazia da essência sobre a forma como uma técnica, idealizada pelos estudiosos da ciência contábil, com vistas a tornar as demonstrações financeiras mais úteis e apresentáveis, colimando, em última análise, atingir o propósito primordial da contabilidade, qual seja: a tomada de decisões por seus usuários. Assim deve ser concebida porque, se a contabilidade é um instrumento que serve como fonte de úteis informações para seus usuários, a primazia da essência sobre a forma somente pode ser entendida dentro desse contexto, constituindo-se numa técnica para que a própria contabilidade consiga alcançar seus objetivos.

Por meio da adoção desta técnica, os usuários da contabilidade passam a visualizar determinados tipos de negócios jurídicos sendo retratados sem qualquer compromisso com o regime jurídico correspondente ou com a maneira pela qual eles se manifestam e se comprovam. Em detrimento disso, o contabilista vai em busca de expedientes hábeis a possibilitar a análise prospectiva da companhia, podendo até ser influenciado pela apresentação contábil de outros tipos de negócios jurídicos. Exemplificativamente, o arrendamento mercantil financeiro retratado à semelhança da compra financiada de bens ${ }^{259}$; as operações comerciais originárias de recebíveis e exigíveis a longo prazo tratadas como duas operações distintas, uma comercial e outra financeira ${ }^{260}$.

É, pois, dessa maneira que os estudiosos contábeis entenderam que o usuário da contabilidade teria melhores recursos para compreender as operações da companhia e avaliar as suas necessidades econômicas. Afinal de contas - é imprescindível reiterar - o objetivo último da contabilidade é “(...) que sejam úteis a um grande número de usuários em suas avaliações e tomadas de decisão econômica." ${ }^{261}$; ou, de outra maneira, servir para análise prospectiva da companhia.

Eis, portanto, como concebemos a primazia da essência sobre a forma: técnica ou recurso contábil com vistas a tornar as demonstrações financeiras mais úteis e apresentáveis, colimando, em última análise, atingir os propósitos da contabilidade, primordialmente amparar decisões de seus usuários. Assim deve ser concebida porque, se a contabilidade é um instrumento que serve como fonte de úteis informações para usuários em geral, a primazia da essência sobre a forma somente pode ser entendida dentro desse contexto, constituindo-se numa técnica para que a própria contabilidade consiga alcançar

\footnotetext{
${ }^{259}$ Conforme artigo 179, IV, da LSA com redação dada pela Lei $n^{\mathbf{o}} 11.638 / 07$ e Pronunciamento CPC 06, aprovado pela Deliberação CVM n ${ }^{\circ}$ 554/08.

${ }^{260}$ Conforme artigos 183, VIII, da LSA, com redação dada pela Lei no $11.638 / 07$, e 184, III, da LSA, com redação dada pela Lei no 11.941/09, e Pronunciamento CPC 12, aprovado pela Deliberação CVM n ${ }^{\circ}$ 564/08.

${ }^{261}$ Item 12 do Pronunciamento CPC sobre a Estrutura Conceitual para Elaboração e Apresentação das Demonstrações Contábeis.
} 
seus objetivos. Conceber de distinta forma significaria inserir a primazia da essência sobre a forma num contexto diverso da própria contabilidade e de sua atual perspectiva (information approach).

Por essas razões, não pode o aplicador do direito se descuidar na compreensão da contabilidade, notadamente para não correr o risco de atribuir à técnica da primazia da essência sobre a forma (e, em última instância, à própria contabilidade) o poder de constituir-se num infalível e autossuficiente instrumento revelador de vícios jurídicos, sob o argumento de que ela denunciaria a prática de engenharia jurídica artificialmente produzida com o objeto de contornar lei imperativa ou outra forma de vício jurídico. Poderiam argumentar alguns que a reprodução pela contabilidade societária da essência econômica relevaria, por si só, a verdadeira intenção das partes, escondida pela produção artificiosa de documentos jurídicos ${ }^{262}$.

Não concordamos, porém, com essa hipótese.

Em realidade, pode sim o contabilista, sob os auspícios da primazia da essência sobre a forma, idealizar o negócio jurídico retratado e registrá-lo à semelhança de outro, entretanto, assim é admitido porque tal proceder tem por finalidade, dentre outros, tornar o relatório mais eficiente para análise prospectiva da companhia. Eis, portanto, a primazia da essência sobre a forma como técnica contábil.

Artificial, tal como um quadro que retrata o objeto inspirador do pintor em relação, sempre será o próprio relatório gráfico contábil, instrumento idealizado para fornecer aos usuários informações pertinentes. Sublinhe-se que o objeto retratado e o próprio retrato constituem-se duas realidades de díspares dimensões.

Em suma, pretendemos significar que, se imaginarmos a contabilidade (o retrato) como representação simbolizada e idealizada do objeto retratado, incapaz, por essa razão, de ser reflexo fiel de aspectos legais e mesmo econômicos ${ }^{263}$ (objetos retratados), não há sequer que cogitar ser ela um instrumento autossuficiente para análise da natureza jurídica do negócio retratado. Na abalizada opinião de Ricardo Mariz de Oliveira:

\footnotetext{
${ }^{262}$ Preocupa-nos a afirmação de Edison Carlos Fernandes no sentido de que a divergência entre a realidade econômica e a forma jurídica, embora não anule o negócio jurídico, demonstra tratar-se de dissimulação (Cf. FERNANDES, Edison Carlos. Lei Contábil e o custo dos tributos. In: FERNANDES, Edison Carlos. PEIXOTO, Marcelo Magalhães (coords.). Aspectos tributários da nova lei contábil: Lei 11.638/07. São Paulo: MP Ed., 2010. p. 22).

${ }^{263}$ A propósito, os economistas vislumbram a dicotomia entre o lucro contábil e o lucro econômico. O primeiro seria incapaz de demonstrar os custos de oportunidade dos empreendimentos, razão pela qual, ainda que contabilmente lucrativo, os economistas podem visualizar prejuízos apurados pelas companhias. Nesse sentido, ver PASSOS, Carlos Roberto Martins. NOGAMI, Otto. Princípios de Economia. 5.ed. São Paulo: Thomsom Leaning, 2006. p. 241 a 243.
} 
“(...) a natureza jurídica dos seres do direito (atos ou negócios jurídicos, com seus elementos constitutivos) é determinada pelas normas jurídicas que os disciplinam, e não por normas, ainda que legais, voltadas para o seu assentamento gráfico contábil."264

Corroborando essa conclusão, aduz Antonio Lopo Martinez em sua dissertação de mestrado sobre a linguagem contábil no Direito Tributário, apresentada à Pontifícia Universidade Católica de São Paulo:

"O Direito incide sobre os fatos contábeis, mas a natureza destes é diferente, pois a Contabilidade tem por objeto essencial a grandeza econômica do patrimônio e suas variações em face dos atos de gestão, enquanto o Direito aprecia os fenômenos do ponto de vista da harmonia social." 265

Uma realidade é constituída pelos fatos jurídicos e seus efeitos patrimoniais; outra, completamente diferente, é a forma como a contabilidade idealiza e interpreta à sua específica maneira os eventos, vertendo-os para a sua linguagem com os propósitos aludidos alhures.

Nessa perspectiva, a escrituração contábil perde, em alguma intensidade, sua força probante. A esse respeito, são oportunas as indagações e, principalmente, a resposta fornecida por Elidie Palma Bifano:

"Em que medida fatos e atos contabilizados sem considerar sua natureza jurídica, mas uma metodologia contábil, podem ser usados como prova judicial, por exemplo? Deixaria um juiz de considerar os elementos jurídicos que conformam um negócio para examiná-los do ponto de vista da Contabilidade? O que parece mais acertado é afirmar que, daqui em diante, nem sempre a Contabilidade será elemento decisivo de prova, porém, tampouco poderá criar direitos ou obrigações, em detrimento dos contratos firmados."266

Para que os aplicadores do direito (advogados, agentes fiscais, juízes, etc.) possam corretamente captar essa nova perspectiva contábil, a primazia da essência sobre a forma bem que poderia ser resumida como a "primazia do tipo econômico sobre o regime

264 OLIVEIRA, Ricardo Mariz. Fundamentos do Imposto de Renda. São Paulo: Quartier Latin, 2008. ps. 1.061 e 1.062.

265 MARTINEZ, Antonio Lopo. A linguagem contábil no Direito Tributário. Dissertação. Mestrado. Pontifícia Universidade de São Paulo, 2002. p. 44.

266 BIFANO, Elidie Palma. Contabilidade e direito: a nova relação. In: MOSQUERA, Roberto Quiroga. LOPES, Alexsandro Broedel (coords.). Controvérsias Jurídico-Contábeis (aproximações e distanciamentos). São Paulo, Dialética, 2010. p. 134. 
jurídico”. Isso porque os contabilistas, a partir de notas típicas comuns existentes em dois ou mais negócios, registram todos da mesma maneira ${ }^{267}$, em detrimento das especificidades de cada um dos regimes jurídicos. Preferem-se as notas típicas numa perspectiva econômico-informacional às especificidades de cada regime jurídico.

\subsection{A JURIDICIZAÇÃO DA CONTABILIDADE NO DIREITO SOCIETÁRIO}

\subsubsection{A DISCIPLINA DAS DEMONSTRAÇÕES CONTÁBEIS NO BOJO DA LEGISLAÇÃO SOCIETÁRIA: SUAS FUNÇÕES}

A LSA, consoante disposto em seu artigo 176, aduz que, ao cabo de cada exercício social, a diretoria fará elaborar demonstrações financeiras, que deverão exprimir com clareza a situação do patrimônio da companhia e as mutações ocorridas no exercício. Não bastasse isso, a LSA fornece - ainda que de forma não exaustiva - critérios contábeis para que se alcance o assentamento gráfico do patrimônio da companhia, entre os quais a própria disposição do balanço patrimonial constante do artigo 178, a definição de que os registros obedecerão ao regime de competência (artigo 177) e outros diversos mandamentos a serem observados pelas companhias.

É importante ressaltar que tais obrigações insertas na lei societária representam, em realidade, valiosos instrumentos eleitos pelo legislador ordinário para disciplinar as relações jurídicas entre as companhias, administradores, acionistas, dentre outros. Não sem razão Roberto Pasqualin Filho, em seus comentários à LSA, afirmou há algumas décadas que:

"Embora a medição dos resultados anuais tenha a aparência de aritmética simples, informada pela ciência contábil, trata-se na verdade de um processo complexo, de relevantes efeitos jurídicos não apenas nas relações pertinentes à sociedade em si, mas também nas relações desta com terceiros, entendidos

\footnotetext{
267 "Em geral, não há dificuldades para a contabilidade registrar o fato econômico exatamente como ele é no direito (...), ocorrendo as diferenças em caráter excepcional, quando o contabilista "enxerga" (por interpretação segundo sua ótica), no negócio jurídico praticado, algum efeito semelhante ao de outro negócio jurídico.” (MARIZ, Ricardo Mariz de. A Tributação da renda e sua relação com os princípios contábeis geralmente aceitos. In: MOSQUERA, Roberto Quiroga. LOPES, Alexsandro Broedel (coords.). Controvérsias Jurídico-Contábeis (aproximações e distanciamentos). São Paulo, Dialética, 2010. ps. 402 e 403.)
} 
estes como os acionistas, empregados, administradores, clientes, fornecedores, governo - a comunidade, enfim, em que a empresa desenvolve atividade diária.",268

Daí porque não ser incomum a alusão à contabilidade societária. E se, com base nela, apura-se a existência de relações jurídicas (inclusive fora do âmbito societário), nada mais coerente do que advogar pela juridicização da contabilidade, a ponto de afirmarmos, incentivados por Renato Renck, que o aplicador do direito que não conhece a contabilidade societária está desabilitado, tecnicamente, para decidir determinadas questões jurídicas $^{269}$.

As normas atinentes à escrituração contábil das companhias não estão inseridas no bojo da LSA por meras circunstâncias fortuitas. Sequer foram introduzidas nesse diploma normativo exclusivamente para difundir, entre os empreendedores brasileiros, a prática de eficientes controles em prol de interesses estritamente gerenciais.

Mais do que apenas isso, o legislador assim procedeu tendo em mira a necessidade de disciplinar a relação jurídica entre companhias e terceiros, como seus administradores e acionistas. Com efeito, é por meio desse expediente que se pode aferir, v.g., se o administrador da companhia, na terminologia do artigo 153 da LSA, empregou o cuidado e diligência que todo homem ativo e probo costuma empregar na administração dos seus próprios negócios; é também por meio dele que se inicia a avaliação sobre a existência, ou não, da relação jurídica entre a companhia e os acionistas relativamente à distribuição de dividendos, etc.

Desta sumária exposição, resta evidente a pluralidade de usuários da contabilidade societária, bem como de finalidades pretendidas pelo legislador ordinário quando da juridicização desse instrumento. Nesse sentido, são pertinentes as conclusões do comercialista Fran Martins sobre a inserção da contabilidade no direito societário. Em suas palavras, a escrituração contábil se presta a possibilitar: “a) vigilância e controle da obra e dos órgãos da administração; b) determinação dos resultados e da eficiência da gestão no

\footnotetext{
268 PASQUALIN FILHO, Roberto. Comentários à Lei das sociedades por ações: Lei 6.404/76. In: Geraldo de Camargo Vidigal e Ives Gandra da Silva Martins (coord.). São Paulo: Ed. Resenha Universitária: Instituto dos Advogados de São Paulo, 1978. p. 130-131.

269 Renato Renck fez afirmação semelhante quando de seu estudo acerca dos aspectos material e quantitativo do imposto de renda das pessoas jurídicas. São suas as seguintes palavras: “(...) se a contabilidade constitui a linguagem jurídica que expressa o valor renda, o aplicador que não a conheça está desabilitado, tecnicamente, para decidir questões tributárias relativas ao Imposto de Renda." (RENCK, Renato Romeu. Imposto de renda da pessoa jurídica: critérios constitucionais de apuração da base de cálculo: uma proposta de interpretação sistemática do Direito. Porto Alegre: Livraria do Advogado, 2001. p. 127.)
} 
que pertine aos seus objetivos específicos: c) controle de marcha das operações e de suas tendências, de forma a permitir correções ou previsões." 270

Eis, portanto, a juridicização da contabilidade pelo direito societário, a qual sofreu significativa reforma desde a edição da Lei $n^{\circ}$ 11.638/07.

\subsubsection{A REFORMA DA LEI DAS SOCIEDADES ANÔNIMAS}

\subsubsection{BREVE CONTEXTUALIZAÇÃO E MOTIVOS DA REFORMA}

Insta aduzir que o tema da juridicização da contabilidade, antes de rara familiaridade entre os operadores do direito, ganhou destacada complexidade com a edição das Leis $n^{\circ} \mathrm{s} 11.638 / 07$ e 11.941/09, as quais reformaram o capítulo das demonstrações financeiras da LSA, com o objetivo primordial de estimular o processo de convergência contábil internacional e facilitar o acesso das empresas brasileiras a capitais externos.

Tais mudanças legislativas são frutos de impulso dado pela CVM, a qual elaborou o anteprojeto de reformulação da LSA, iniciado com a seguinte justificação:

"Este anteprojeto visa a adequar disposições da Lei das Sociedades por Ações

(Lei $\mathrm{n}^{\circ}$ 6.404/76), principalmente aquelas constantes dos seus capítulos XV, XVI, XVIII e XX, que tratam da matéria contábil, à nova realidade da economia brasileira, levando-se em conta o processo, cada vez mais crescente, de globalização dos mercados, bem como a evolução havida, em nível mundial, dos Princípios Fundamentais de Contabilidade."

Com a edição das Leis no 11.638/07 e 11.941/09, a contabilidade societária, atendendo às demandas da economia globalizada, passou a ser um expediente mais eficiente de acesso das empresas brasileiras a capitais estrangeiros. Para tanto, como resultado da abertura da economia brasileira para o exterior, buscou-se a harmonização entre as práticas contábeis brasileiras e as oriundas dos principais mercados internacionais de valores mobiliários. Não por outra razão, dispõe da seguinte maneira o $\$ 5^{\circ}$ do artigo 177 da LSA (redação dada pela Lei n ${ }^{\circ}$ 11.638/07): “As normas expedidas pela Comissão de Valores Mobiliários a que se refere o $\S 3^{0}$ deste artigo deverão ser elaboradas em

270 apud CÂMARA, Miriam C. R., FESLBERG, Thomas Benes. Contabilização de Operações e Arrendamento Mercantil. Revista de Direito Mercantil, Industrial, Econômico e Financeiro. No 68, 1987. p. 112. 
consonância com os padrões internacionais de contabilidade adotados nos principais mercados de valores mobiliários."

Mais do que isso, o artigo $5^{\circ}$ da Lei ${ }^{\circ} 6.385 / 76$, com redação dada pela Lei $n^{\circ}$ 11.638/07, autorizou a CVM, o BACEN e demais órgãos e agências reguladoras a celebrarem convênio com entidade que tenha por objeto o estudo e a divulgação de princípios, normas e padrões de contabilidade e de auditoria, podendo os organismos relacionados adotar, total ou parcialmente, os pronunciamentos assim emitidos.

Ganhou força, assim, o CPC, órgão criado pela Resolução nº 1.055/05 do CFC e que tem por missão estudar, pesquisar, discutir e deliberar a emissão de pronunciamentos contábeis que auxiliem na uniformização das normas brasileiras de contabilidade. Desde sua criação, o CPC tem emitido diversos pronunciamentos contábeis nitidamente inspirados nos IRFS (às vezes, meras traduções), os quais têm sido adotados pela CVM, pelo CFC e diversos órgãos estatais.

Não bastassem tais pronunciamentos, as próprias alterações promovidas desde a edição da Lei $n^{\circ}$ 11.638/07 representam a superação de obstáculos para a convergência internacional do padrão contábil. Basta conferir, a título exemplificativo, o novo conteúdo do ativo imobilizado (artigo 179, IV, da LSA), que alberga os direitos sobre bens, inclusive os decorrentes de operações que transfiram à companhia os benefícios, riscos e controle desses bens.

Daí a razão pela qual poder-se afirmar, sem receios, que a contabilidade juridicizada pelo direito societário, por facilitar o processo de convergência contábil internacional, está de mãos dadas com a atual perspectiva da contabilidade (information approach).

\subsubsection{2. ÂMBITO DE APLICAÇÃO}

O artigo $177, \S 3^{\circ}$, da LSA determina às companhias abertas observarem as normas contábeis expedidas pela CVM, as quais, por suas vez, serão elaboradas em consonância com os padrões internacionais de contabilidade adotados nos principais mercados de valores mobiliários ${ }^{271}$.

${ }^{271} \mathrm{O}$ artigo $22, \S 1^{\circ}$, IV, da Lei $\mathrm{n}^{\circ} 6.385 / 76$, reafirmando esse mesmo conteúdo, determina que a CVM expedirá normas aplicáveis às companhias abertas sobre padrões de contabilidade, relatórios e pareceres de auditores independentes. 
Quanto às companhias fechadas, o $\$ 6^{\circ}$ do artigo 177 da LSA apenas faculta a utilização de tais pronunciamentos, o que poderia suscitar dúvidas no que diz respeito à obrigatoriedade da adoção de uma série de normas internacionalmente consagradas nos principais mercados.

Essas mesmas dúvidas poderiam ocorrer no que tange às sociedades que não adotam a forma de sociedade anônima, não se sujeitando, via de regra, aos comandos da $\mathrm{LSA}^{272}$. Corroborando isso, o artigo $3^{\circ}$ da Lei $n^{\circ} 11.638 / 07$ reza que às sociedades de grande porte, assim definidas no parágrafo único, são aplicáveis as regras sobre escrituração e elaboração de demonstrações financeiras, ainda que não adotarem a forma de sociedade anônima.

Em suma, da análise desses dispositivos isoladamente do restante do direito positivo, poder-se-ia vislumbrar que: (i) as companhias abertas, obrigatoriamente, e as companhias fechadas, facultativamente, teriam suas demonstrações financeiras inteiramente convergentes com as normas internacionais (partindo-se da premissa de que a CVM disciplina nessa direção); (ii) as companhias fechadas que não optarem pela aplicação das normas emanadas da CVM, elaborariam suas demonstrações financeiras partindo, exclusivamente, dos critérios contábeis previstos na LSA, ignorando o conteúdo as normas da CVM; (iii) as demais sociedades empresárias elaborariam suas demonstrações financeiras alheias aos valores consagrados pela LSA, salvo as de grande porte e as que expressamente admitirem aplicação da LSA, conforme previsão no contrato social.

Porém, as duas últimas conclusões acima não passam pelo teste da análise conjunta e sistemática do direito positivo. Vejamos.

Deve-se ter em mente que os pronunciamentos contábeis emitidos pelo CPC, além de adotados pela CVM, também o são pelo CFC, órgão fiscalizador da profissão contábil. Via de consequência, passa a ser de observância obrigatória para todos os contabilistas $^{273}$, sob pena de configuração de infração disciplinar ${ }^{274}$. A propósito, o CPC

${ }^{272}$ Salvo nos casos em que o contrato social expressamente admitir aplicação da LSA (artigo 1.053, parágrafo único, do Código Civil).

${ }^{273}$ Nesse mesmo sentido, MOSQUERA, Roberto Quiroga; LOPES, Alexsandro Broedel. O Direito Contábil - Fundamentos Conceituais, Aspectos da Experiência Brasileira e Implicações. In: MOSQUERA, Roberto Quiroga. LOPES, Alexsandro Broedel (coords.). Controvérsias Jurídico-Contábeis (aproximações e distanciamentos). São Paulo, Dialética, 2010. p. 68; FERNANDES, Edison Carlos. Lei Contábil e o custo dos tributos. In: FERNANDES, Edison Carlos. PEIXOTO, Marcelo Magalhães (coords.). Aspectos tributários da nova lei contábil: Lei 11.638/07. São Paulo: MP Ed., 2010. p. 16; SCHOUERI, Luís Eduardo. TERSI, Vinicius Feliciano. Algumas ponderações a respeito do regime tributário de transição. In: FERNANDES, Edison Carlos. PEIXOTO, Marcelo Magalhães (coords.). Aspectos tributários da nova lei contábil: Lei 11.638/07. São Paulo: MP Ed., 2010. ps. 355 e 356; BIFANO, Elidie Palma. O Direito 
aprovou pronunciamento contábil específico para pequenas e médias empresas, tendo sido adotado pelo CFC (por meio da Resolução no 1.255/09), o qual, em linhas gerais, está em consonância com os padrões internacionais de contabilidade ${ }^{275}$.

Ademais, não se deve desprezar que o caput do artigo 177 da LSA faz menção à utilização dos princípios de contabilidade geralmente aceitos, sendo de observância obrigatória para todas as companhias (abertas e fechadas) e demais sociedades sujeitas à LSA por expressa previsão no contrato social. As normas acolhidas pelo CFC originadas do CPC, ainda que se possa negar sua caracterização enquanto princípios de contabilidade geralmente aceitos $^{276}$, representam a concretização deles, sendo de aplicação obrigatória para que se mantenha a uniformidade do padrão contábil no país.

Por fim, quanto às demais sociedades empresárias, devemos lembrar que o Código Civil, quando disciplina a escrituração do empresário (artigo 1.179 usque 1.195), é pobre quanto a critérios contábeis a serem adotados. Tanto que o artigo 1.189 reza que "o balanço de resultado econômico, ou demonstração da conta de lucros e perdas, acompanhará o balanço patrimonial e dele constarão crédito e débito, na forma de lei especial.” Sobre a lei especial de que trata o indigitado dispositivo, Ricardo Fiuza, aduz:

"Para a sociedade anônima, vale sua lei específica. Enquanto não existir a lei especial a que se refere este artigo para regular a matéria, à falta de norma própria, devem ser aplicadas as disposições da Lei das Sociedades Anônimas, que é o tipo principal de sociedade empresária." 277

Em suma, devido à ausência de disciplina específica sobre a contabilidade para as demais sociedades no Código Civil, deve ser observada a disciplina dispensada pela $\mathrm{LSA}^{278}$.

Contábil: da Lei $n^{o}$ 11.638/07 à Lei $n^{o}$ 11.941/09. In: ROCHA, Sergio André (cood.). Direito Tributário, Societário e a Reforma da Lei das S/A. Vol. II. São Paulo: Quartier Latin, 2010. p. 198.

${ }^{274}$ Art. $9^{\circ}$ da Resolução CFC n ${ }^{\circ} 1.328 / 11$.

${ }^{275}$ Foge do escopo de nosso trabalho a análise minuciosa do Pronunciamento CPC Contabilidade para Pequenas e Médias Empresas, o qual, por sua vez, foi inspirado pelo IFRS for SMEs. Porém, mesmo numa análise superficial do pronunciamento, percebe-se que não foi omisso quanto aos critérios internacionalmente consagrados. Vide, por exemplo, a seção 20 (operações de arrendamento mercantil).

${ }^{276}$ Segundo José Luiz Bulhões Pedreira, "a expressão 'princípios de contabilidade geralmente aceitos' tem origem no texto padronizado de parecer adotado pelo auditores nos Estados Unidos na década de 1930 e não significa procedimentos contábeis pormenorizados, mas postulados básicos que muitas vezes podem ser implementados segundo práticas diversas." (PEDREIRA, José Luiz Bulhões. Imposto sobre a Renda Pessoas Jurídicas. Vol. I. Rio de Janeiro: Justec, 1979. p. 272.)

${ }^{277}$ FIUZA, Ricardo (coord.). Novo Código Civil Comentado. São Paulo: Saraiva, 2002. p. 1.057.

${ }^{278}$ Nesse sentido, FERNANDES, Edison Carlos. Lei Contábil e o custo dos tributos. In: FERNANDES, Edison Carlos. PEIXOTO, Marcelo Magalhães (coords.). Aspectos tributários da nova lei contábil: Lei 11.638/07. São Paulo: MP Ed., 2010. p. 16. 
Por tais razões, pode-se concluir que a contabilidade societária praticada no Brasil é única, tendo suporte da $\operatorname{LSA}^{279}$ e da disciplina dispensada pelo CPC e CFC, não havendo distinção em razão do tipo societário adotado ${ }^{280}$.

\subsection{A JURIDICIZAÇÃO DA CONTABILIDADE NO REGIME DO IMPOSTO DE RENDA}

\subsubsection{O LUCRO CONTÁBIL COMO PONTO DE PARTIDA PARA IDENTIFICAÇÃO DA BASE TRIBUTÁVEL}

O Direito Tributário tem se valido da juridicização da contabilidade. A propósito, nessa seara do Direito, como bem concluiu Antonio Lopo Martinez, a linguagem contábil presta um relevante papel, “(...) servindo, ao mesmo tempo, como meio de prova para a constituição dos fatos jurídicos tributários e como unidade de significação na estrutura da norma jurídica tributária.”,281 No que tange a esse último aspecto, “(...) é no critério quantitativo (da regra-matriz de incidência tributária) que a linguagem contábil se faz presente de modo mais marcante." 282

A afirmação supra, no que tange ao regime do IRPJ, não poderia ser mais oportuna, na medida em que o legislador tributário incorporou o regime contábil consagrado pelo Direito Societário, de modo que o lucro contábil antes da provisão do próprio imposto $^{283}$ constitui o passo inicial do processo de apuração da base de cálculo do IRPJ das empresas optantes ou obrigadas ao regime do Lucro Real. Com efeito, a base de cálculo nesse caso é encontrável a partir do lucro contábil, o qual se submeterá a ajustes

\footnotetext{
${ }^{279}$ Divergimos, portanto, de Ricardo Lacaz Martins, para quem as disposições da Lei ${ }^{\circ}$ 11.638/07 somente alcançam as companhias e sociedades de grande porte (Cf. MARTINS, Ricardo Lacaz. A Tributação da Renda Imobiliária. Tese. Doutorado. Universidade de São Paulo, 2009. p. 93.).

280 "Há três décadas no Brasil só se faz um tipo de contabilidade, a baseada na Lei no 6.404/76. Diferenças de práticas contábeis entre diferentes empresas existem, mas elas não ocasionada, por exemplo, por uma ser "Limitada" e outra ser "S.A."; o que pode provocar tais distinções são as atividades. Óbvio, uma instituição financeira e uma indústria têm aspectos específicos de operação e, portanto, podem requerer tratamentos contábeis diferenciados." (MOSQUERA, Roberto Quiroga; LOPES, Alexsandro Broedel. O Direito Contábil - Fundamentos Conceituais, Aspectos da Experiência Brasileira e Implicações. In: MOSQUERA, Roberto Quiroga. LOPES, Alexsandro Broedel (coords.). Controvérsias Jurídico-Contábeis (aproximações e distanciamentos). São Paulo, Dialética, 2010. ps. 67 e 68.)

${ }^{281}$ MARTINEZ, Antonio Lopo. A linguagem contábil no Direito Tributário. Dissertação. Mestrado. Pontifícia Universidade de São Paulo, 2002. p. 120.

${ }^{282}$ MARTINEZ, Antonio Lopo. A linguagem contábil no Direito Tributário. Dissertação. Mestrado. Pontifícia Universidade de São Paulo, 2002. p. 121.

${ }^{283}$ Resultado do exercício, na expressão consagrada pela LSA, ou lucro líquido do período, pela legislação do IRPJ.
} 
(adições, exclusões e compensações) estabelecidos pela legislação do IRPJ (artigo $6^{\circ}$ do Decreto-Lei $n^{\circ}$ 1.598/77). Feitos tais ajustes, chega-se, enfim, ao Lucro Real ou Lucro Fiscal, base de cálculo do IRPJ ${ }^{284}$.

Vê-se, portanto, que o legislador tributário juridicizou a contabilidade, por meio de remissão ao Direito Societário. Poderia ter feito como no México, por exemplo, onde não existe nenhuma conexão formalmente estabelecida entre a determinação da renda tributável e o Direito Comercial ${ }^{285}$. Porém, assim não o fez, razão pela qual o lucro contábil, apurado de acordo com a legislação comercial, é o ponto de partida para apuração da base de cálculo do IRPJ.

Note-se que a contabilidade societária foi criada para não sofrer qualquer sorte de influências da legislação tributária ou qualquer outra de caráter especial. A redação original do artigo $177, \S 2^{\circ}$, da LSA prescrevia que:

“A companhia observará em registros auxiliares, sem modificação da escrituração mercantil e das demonstrações reguladas nesta Lei, as disposições da lei tributária, ou de legislação especial sobre a atividade que constitui seu objeto, que prescrevam métodos ou critérios contábeis diferentes ou determinem a elaboração de outras demonstrações financeiras."

Com a edição da Lei $\mathrm{n}^{\circ} 11.638 / 07$, tal dispositivo foi alterado para conferir às companhias duas possibilidades, quais sejam: (i) elaborar suas demonstrações financeiras nos moldes da LSA, inserindo em livros auxiliares quaisquer utilizações de métodos ou critérios contábeis diferentes prescritas na legislação tributária ou especial; (ii) elaborar suas demonstrações financeiras para fins tributários para, em seguida, efetuar na escrituração comercial ajustes para observância dos critérios consagrados pela LSA. Vislumbrava-se, assim, a criação do Livro de Apuração do Lucro Contábil - LALUC, livro que contemplaria os ajustes acima citados.

\footnotetext{
${ }^{284}$ Não ignoramos que o lucro contábil nem sempre será o ponto de partida da apuração da base de cálculo do IRPJ. Não o será nos casos da adoção dos regimes do Lucro Presumido, Arbitrado e Simples Nacional, que são admitidos pelo direito positivo como instrumentos de consagração de outros valores constitucionais como os da praticidade e do tratamento diferenciado e favorecido às pequenas e médias empresas. Porém, nenhum desses regimes poderá ser imposto aos contribuintes, mas tão somente dada a oportunidade de adesão a eles (ainda que de maneira irretratável). Isso porque tais regimes, no que tange ao processo de mensuração da base de cálculo, não levam em conta o acréscimo patrimonial dos contribuintes. Sendo assim, nossas atenções no curso do presente trabalho estarão voltadas ao regime do Lucro Real.

${ }^{285}$ Cf. POLIZELLI, Victor Borges. Balanço Comercial e Balanço Fiscal: Relaçães entre o Direito Contábil e o Direito Tributário e o Modelo Adotado pelo Brasil. in: Direito Tributário Atual $\mathrm{n}^{\circ}$ 24. Coords. BONILHA, Paulo Celso Bergstrom, COSTA, Alcides Jorge, SCHOUERI, Luís Eduardo, ZILVETTI, Fernando Aurélio. São Paulo: Dialética, 2010. p. 593.
} 
Essa última possibilidade não chegou a ser posta em prática, uma vez que a Medida Provisória 449/08, posteriormente convertida na Lei $\mathrm{n}^{\circ} 11.941 / 09$, alterou novamente a redação do artigo 177 da LSA, restabelecendo a obrigatoriedade de, na escrituração comercial, serem observadas as diretrizes constantes da LSA e, em livros auxiliares, quaisquer outros métodos e critérios contábeis advindas da legislação tributária ou comercial.

Com efeito, as determinações constantes na legislação do IRPJ não devem ser refletidas na escrituração comercial, merecendo ser acolhidas apenas no livro auxiliar. Reforçando essa determinação originalmente constante na LSA, a lei tributária (o DecretoLei $\left.n^{\circ} 1.598 / 77\right)$ positivou o LALUR, no qual devem ser: a) lançados os ajustes do lucro líquido do exercício prescritos na legislação tributária; b) transcrita a demonstração do lucro real; c) mantidos os registros de controle de prejuízos a compensar em exercícios subsequentes, de depreciação acelerada, de exaustão mineral com base na receita bruta, de exclusão por investimento das pessoas jurídicas que explorem atividades agrícolas ou pastoris e de outros valores que devam influenciar a determinação do lucro real de exercício futuro e não constem de escrituração comercial.

E assim foi feito para que a escrituração comercial continuasse a atingir seus propósitos específicos (proteção de credores, investidores, fiscalização da administração, etc.) e não fosse prejudicada pela influência dos critérios fiscais que visam, em última análise, a arrecadação tributária ${ }^{286}$.

\subsubsection{OS CRITÉRIOS CONTÁBEIS PREVISTOS NA LEGISLAÇÃO TRIBUTÁRIA}

A despeito disso, não se pode ignorar que, nessas últimas décadas, viu-se uma significativa influência da legislação do IRPJ nos critérios contábeis brasileiros, inclusive para fins de elaboração das demonstrações financeiras preparadas para atender os propósitos da LSA. A legislação tributária, não raro, determina ajustes de natureza

\footnotetext{
${ }^{286}$ Tanto foi assim que o projeto do Decreto-Lei $\mathrm{n}^{\circ} 1.598 / 77$ foi assim justificado pelo Ministério da Fazenda: "A lei de sociedades por ações seguiu a orientação de manter separação nítida entre a escrituração comercial e a fiscal, porque as informações sobre a posição e os resultados financeiros das sociedades são reguladas na lei comercial com objetivos diversos dos que orientam a legislação tributária, e a apuração de resultados e as demonstrações financeiras exigidas pela lei comercial não devem ser distorcidas em razão de conveniências da legislação tributária." (apud PEDREIRA, José Luiz Bulhões. Imposto sobre a Renda Pessoas Jurídicas. Vol. I. Rio de Janeiro: Justec, 1979. p. 274.)
} 
estritamente fiscais na própria escrituração comercial ${ }^{287}$. Noutras situações, preenchia lacunas existentes na $\mathrm{LSA}^{288}$. A propósito, pode-se afirmar que a influência da legislação do imposto de renda na contabilidade não é fenômeno exclusivamente brasileiro, sendo um importante instrumento para o aperfeiçoamento das práticas gerais de contabilidade e na preservação de uniformidade ${ }^{289}$.

De todo modo, no Brasil, tal influência chegou a ser tamanha que, na prática brasileira da escrituração comercial, os contabilistas utilizaram-se de critérios tributários incompatíveis com os critérios previstos na LSA. E tal acontecia em razão do receio de que a fiscalização não aceitasse efeitos tributários para eventos que não tinham lastro na escrituração comercial ${ }^{290}$.

Parece-nos ser exemplo eloquente as depreciações de ativo imobilizado. Ao invés de avaliarem as condições e especificidades de suas operações e, a partir disso, identificarem a taxa de depreciação (como sempre determinou a LSA), as empresas simplesmente utilizavam, na escrituração comercial, a taxa fixada pelo Fisco, mensurada indistintamente para todas as empresas, em função do prazo durante o qual se possa esperar a utilização econômica do bem, em condições normais e médias ${ }^{291}$.

Em suma, os métodos e critérios contábeis previstos na legislação tributária, que nasceram para figurarem apenas no LALUR, acabaram por ser incorporados pela própria escrituração comercial das empresas.

Seja como for, com a juridicização, pelo Direito Societário, da convergência contábil internacional, a qual, por sua vez, acolhe a perspectiva da informação (information approach), parece-nos que os critérios contábeis previstos na legislação tributária serão cada vez menos incorporados na escrituração comercial. Isso porque, como bem anotou Victor Borges Polizelli, “atualmente, por força das modificações trazidas pelas Leis $\mathrm{n}^{\circ}$ 11.638/07 e 11.941/09, a Contabilidade comercial e a Contabilidade fiscal deverão exprimir certos distanciamentos." 292 Trata-se da quebra de um paradigma histórico para a

\footnotetext{
${ }^{287}$ Vide o exemplo dos ajustes de preços de transferências na escrituração comercial dos contribuintes (artigo $5^{\circ}$ da Instrução Normativa $n^{\circ} 243 / 02$ ).

${ }^{288}$ Vide o exemplo do tratamento contábil dispensado às operações de incorporação, fusão e cisão (Lei $\mathrm{n}^{\circ}$ 9.532/97).

289 Cf. HENDRIKSEN, Eldon S.; BREDA, Michael F. Van. Teoria da Contabilidade. 1. ed. 8. reimpr. Tradução de Antonio Zoratto Sanvicente. São Paulo: Atlas, 2010. p. 23.

${ }^{290}$ Nesse sentido, o Parecer Normativo n ${ }^{\circ}$ 96/78.

${ }^{291}$ Cf. BOZZA, Fábio Piovesan. O Novo Padrão Contábil Brasileiro e os Impactos Fiscais no Registro das Despesas de Depreciação. In: Revista Dialética de Direito Tributário no 166. São Paulo: Dialética, 2009. p. 89 e 90.

292 POLIZELLI, Victor Borges. Balanço Comercial e Balanço Fiscal: Relações entre o Direito Contábil e o Direito Tributário e o Modelo Adotado pelo Brasil. in: Direito Tributário Atual $\mathrm{n}^{\circ} 24$. Coords. BONILHA,
} 
contabilidade, pois espera-se deixar de sofrer constantes influências da legislação tributária $^{293}$.

A não incorporação, na escrituração comercial, dos critérios contábeis previstos na legislação tributária parece ser tão significativa que a RFB, que já dispunha do LALUR como instrumento de positivação das diferenças entre critérios societários e tributários, criou o FCONT por meio da edição da Instrução Normativa RFB nº 949/09.

Trata-se, como anuncia o artigo $8^{\circ}$, de uma escrituração das contas patrimoniais e de resultado, em partidas dobradas, que considera os métodos e critérios contábeis aplicados pela legislação tributária.

Com ele, parece-nos que, mais do que nunca, instaura-se no Brasil a Contabilidade Tributária ${ }^{294}$. Note-se que, se antes se via apenas uma contabilidade (a societária com significativas influências de critérios contábeis previstos na legislação tributária), hoje estamos diante de, por um lado, uma Contabilidade Societária pura (LSA e pronunciamentos do $\mathrm{CPC}$ ) e, de outro, uma Contabilidade Tributária (a antiga contabilidade, isto é, a contabilidade societária com as influências de critérios contábeis previstos na legislação tributária) ${ }^{295}$.

\subsubsection{O REGIME TRIBUTÁRIO DE TRANSIÇÃO}

Por conta dos objetivos perseguidos pela juridicização no Direito Societário da convergência contábil internacional, os debates em torno do então Projeto de Lei $n^{\circ}$ 3.741/00 (idealizado pela CVM) pautaram-se também pelo que se convencionou denominar "neutralidade fiscal", ou seja, as novas disposições contábeis não poderiam afetar a mensuração das bases tributáveis.

Paulo Celso Bergstrom, COSTA, Alcides Jorge, SCHOUERI, Luís Eduardo, ZILVETTI, Fernando Aurélio. São Paulo: Dialética, 2010. p. 599.

${ }^{293}$ Nesse sentido, NICACIO, Carlos N.. QUERQUILLI, Alexandre G. Mudanças nas regras contábeis, experiências internacionais e a relativa neutralidade do regime tributário de transição. In: FERNANDES, Edison Carlos. PEIXOTO, Marcelo Magalhães (coords.). Aspectos tributários da nova lei contábil: Lei 11.638/07. São Paulo: MP Ed., 2010. p. 42.

${ }^{294}$ Nesse sentido, BIFANO, Elidie Palma. O Direito Contábil: da Lei $n^{\circ}$ 11.638/07 à Lei $n^{\circ}$ 11.941/09. In: ROCHA, Sergio André (cood.). Direito Tributário, Societário e a Reforma da Lei das S/A. Vol. II. São Paulo: Quartier Latin, 2010. p. 186.

${ }^{295}$ Nesse sentido, Victor Borges Polizelli afirma que, antes das Leis $\mathrm{n}^{\circ} 11.638 / 07$ e 11.941/09, o Brasil adotava o modelo de "balanço único com dependência inversa (ou "liderança do Direito Tributário")". Atualmente, o Brasil teria adotado o modelo de "balanço duplo sem conexão normativa". (Cf. POLIZELLI, Victor Borges.Balanço Comercial e Balanço Fiscal: Relações entre o Direito Contábil e o Direito Tributário e o Modelo Adotado pelo Brasil. in: Direito Tributário Atual $\mathrm{n}^{\circ}$ 24. Coords. BONILHA, Paulo Celso Bergstrom, COSTA, Alcides Jorge, SCHOUERI, Luís Eduardo, ZILVETTI, Fernando Aurélio. São Paulo: Dialética, 2010. p. 608.) 
Tanto isso é verdade que a Lei $\mathrm{n}^{\circ} 11.638 / 07$ acrescentou o $\$ 7^{\circ}$ ao artigo 177 da LSA, vazado nos seguintes termos:

“§7". Os lançamentos de ajuste efetuados exclusivamente para harmonização de normas contábeis, nos termos do $§ 20$ deste artigo, e as demonstrações e apurações com eles elaboradas não poderão ser base de incidência de impostos e contribuições nem ter quaisquer outros efeitos tributários."

A despeito de o citado dispositivo ter sido inspirado pela neutralidade fiscal, fato é que a forma como foi redigido não foi suficiente para, pelo menos de maneira absoluta, alcançar essa finalidade e acalmar as animosidades causadas no mercado. A abrangência desse dispositivo (i.e., a neutralidade fiscal) estava limitada, quando muito, aos casos de divergência entre padrões contábeis previstos na lei societária e aqueles previstos na lei tributária. Nada dizia, por exemplo, sobre os efeitos fiscais decorrentes das novas regras contábeis que não tinham correspondência na legislação tributária ${ }^{296}$.

Diante desse cenário, que ocasionou inúmeras incertezas aos contribuintes e ao próprio fisco, o Presidente da República adotou a Medida Provisória $n^{\circ}$ 449/08, posteriormente convertida na Lei $\mathrm{n}^{\mathrm{o}} 11.941 / 09$, sendo revogado o $§ 7^{\circ}$ do artigo 177 da LSA e instituído o RTT.

O objetivo do RTT foi conferir maior segurança jurídica e certeza na aplicação do direito. A evolução da neutralidade fiscal provocada pela nova lei também foi sentida por Ian Muniz e Marco Antônio M. Monteiro, para quem:

"Se uns poucos meses atrás estávamos todos nós, tributaristas, desencavando do armário o seu arsenal de técnicas interpretativas para assegurar o que a Lei $\mathrm{n}^{\mathrm{o}}$ 11.638/07 havia prometido, mas que dificilmente cumpriria, ou seja, a neutralidade fiscal, a edição da Medida Provisória n 449/08, posteriormente confirmada como a Lei $\mathrm{n}^{\mathrm{o}} 11.941 / 09$, veio a facilitar o caminho para a terra prometida." 297

\footnotetext{
${ }^{296}$ Ricardo Lodi Ribeiro e Adriana Clemente de Souza Tavares têm a mesma opinião: “(...) resta evidente que as alterações introduzidas pela Lei $\mathrm{n}^{\circ} 11.638 / 07$, que provocaram diferenças nos resultados e receitas das empresas, não podem afetar a apuração de tributos, sempre que a lei tributária, de caráter especial, disciplinar o tratamento da operação, ainda que contabilmente, de forma diversa. Contudo a interferência das novas regras introduzidas pela Lei $\mathrm{n}^{\mathrm{o}} 11.638 / 07$ na apuração de tributos ocorrerá nas hipóteses em que a lei tributária não disciplinar expressamente a questão (...)" (RIBEIRO, Ricardo Lodi. TAVARES, Adriana Clemente de Souza. O planejamento fiscal pela metodologia de ajustes a valor presente - AVP introduzida pela Lei $n^{\circ}$ 11.638/2007. In: ROCHA, Sergio André (cood.). Direito Tributário, Societário e a Reforma da Lei das S/A. São Paulo: Quartier Latin, 2008. p. 442.)

${ }^{297}$ MONTEIRO, Marco Antônio M., MUNIZ, Ian. O RTT e a Neutralidade Fiscal. In: ROCHA, Sérgio André (coord). Direito Tributário, Societário e a Reforma da Lei das S/A. Vol. II. São Paulo: Quartier Latin, 2010. p. 266.
} 
De caráter opcional para o biênio 2008-2009 e compulsório para os demais períodos posteriores, tal regime possibilita aos contribuintes apurar o IRPJ e demais contribuições sobre o lucro e receita na forma do regime contábil vigente em 31 de dezembro de 2007, isto é, expurgados de quaisquer efeitos das Leis $n^{\circ} 11.638 / 07$ e $11.941 / 09$, bem como das normas expedidas pelo $\mathrm{CPC}^{298}$.

No que tange ao IRPJ, a neutralidade fiscal na apuração da base de cálculo pela sistemática do Lucro Real se dá na forma de ajustes ao lucro líquido do exercício. Assim, nos termos do artigo 17 da mencionada lei, o cálculo realizar-se-á observado os seguintes atos (na sequência):

(i) utilização do lucro (de partida) apurado de acordo com a LSA, isto é, com a adoção das novas regras contábeis introduzidas pelas Leis $n^{\circ}$ 11.638/07 e 11.941/09, bem assim das normas expedidas pelo CPC;

(ii) realização de ajustes que revertam os efeitos dessas novas regras contábeis, de forma que o lucro contábil se torne igual àquele que poderá ser apurado se vigente o regime contábil de 31 de dezembro de 2007; e

(iii) realização dos demais ajustes de adição, exclusão e compensação, prescritos ou autorizados pela legislação tributária, para apuração da base de cálculo.

Vê-se, portanto, que, para efeitos de apuração do IRPJ, os efeitos das novas regras contábeis - sejam aquelas expressas na Lei ${ }^{\circ}$ 11.638/07 e 11.941/09, sejam aquelas preparadas pelo CPC - são expurgáveis.

De todo modo, pode-se dizer que a neutralidade fiscal - seja por conta da recente introdução do RTT, seja pela tradicional voracidade do Fisco Federal na arrecadação tributária - ainda é vista com certa margem de desconfiança pelos contribuintes, o que exige maiores reflexões e detalhamentos.

\footnotetext{
298 “Art. 16. As alterações introduzidas pela Lei $\mathrm{n}^{\mathrm{o}}$ 11.638, de 28 de dezembro de 2007, e pelos arts. 37 e 38 desta Lei que modifiquem o critério de reconhecimento de receitas, custos e despesas computadas na apuração do lucro líquido do exercício definido no art. 191 da Lei no 6.404, de 15 de dezembro de 1976, não terão efeitos para fins de apuração do lucro real da pessoa jurídica sujeita ao RTT, devendo ser considerados, para fins tributários, os métodos e critérios contábeis vigentes em 31 de dezembro de 2007.

Parágrafo único. Aplica-se o disposto no caput deste artigo às normas expedidas pela Comissão de Valores Mobiliários, com base na competência conferida pelo $\S 3^{\circ}$ do art. 177 da Lei $n^{\circ} 6.404$, de 15 de dezembro de 1976, e pelos demais órgãos reguladores que visem a alinhar a legislação específica com os padrões internacionais de contabilidade."
} 


\subsubsection{A NEUTRALIDADE FISCAL ENQUANTO PRINCÍPIO}

A neutralidade fiscal, enquanto obstáculo para produção de efeitos tributários do novo padrão contábil, está consagrada pela Lei $\mathrm{n}^{\circ} 11.941 / 09$ tanto na forma de positivação de um conteúdo finalístico a ser preservado na aplicação da regra-matriz de incidência do IRPJ, quanto pela indicação de meios para assegurar esse conteúdo.

Já no primeiro dispositivo que trata do RTT, a lei em destaque anuncia o conteúdo finalístico a ser preservado, a saber:

“Art. 15. Fica instituído o Regime Tributário de Transição - RTT de apuração do lucro real, que trata dos ajustes tributários decorrentes dos novos métodos e critérios contábeis introduzidos pela Lei no 11.638, de 28 de dezembro de 2007, e pelos arts. 37 e 38 desta Lei.

$\S 1^{\circ}$ O RTT vigerá até a entrada em vigor de lei que discipline os efeitos tributários dos novos métodos e critérios contábeis, buscando a neutralidade tributária.

(...)"

Assim disposto, parece-nos que a neutralidade fiscal buscada pelo RTT, mais do que regras definidoras de padrões específicos para neutralidade (i.e. indicação de meios para a neutralidade), deve ser concebida como um verdadeiro princípio do regime do IRPJ, instituidor de um conteúdo finalístico a ser preservado, ainda que além dos meios já consagrados.

Para se chegar a essa conclusão, em primeiro lugar, deve-se afastar, de plano, preconceitos quanto à possibilidade de existência de princípios jurídicos consagrados no âmbito da legislação infraconstitucional. Nesse sentido, o Professor Roque Antonio Carrazza sublinha: "Evidentemente, os princípios são encontráveis em todos os escalões da 'pirâmide jurídica'. De fato, há princípios constitucionais, legais e até infralegais." 299

Portanto, a neutralidade fiscal, enquanto princípio jurídico-tributário, pode ser (e de fato foi) positivada no âmbito de legislação ordinária federal.

Prosseguindo nosso raciocínio, para classificar a neutralidade fiscal como um princípio do regime jurídico do IRPJ, valemo-nos dos critérios apontados por Humberto Ávila em seu importante e recorrido estudo sobre a Teoria dos Princípios. Devem eles (os princípios jurídicos) ser entendidos como:

${ }^{299}$ CARRAZZA, Roque Antônio. Curso de Direito Constitucional Tributário. 19. ed. São Paulo: Malheiros, 2004. p. 34. 
“(...) normas imediatamente finalísticas, primariamente prospectivas e com pretensão de complementariedade e de parcialidade, para cuja aplicação se demanda uma avaliação da correlação entre o estado de coisas a ser promovido e os efeitos decorrentes da conduta havida como necessária à sua promoção."300

Com efeito, da redação do artigo 15 da Lei $\mathrm{n}^{\circ}$ 11.941/09 emerge o conteúdo finalístico do princípio da neutralidade fiscal, consistente em evitar que as novas regras contábeis juridicizadas pelo Direito Societário tenham algum tipo de reflexo na seara tributária até que nova lei disponha sobre a forma de apuração das bases de cálculo dos tributos federais.

Não bastasse a própria redação do dispositivo, tal conteúdo é confirmado pela Exposição de Motivos da Medida Provisória no 449/08:

“8. (...) faz-se mister a adoção do RTT, conforme definido nos arts. 15 a 22 desta Medida Provisória, para neutralizar os efeitos tributários e remover a insegurança jurídica. (...) 9. (...) Nesse contexto, o $1^{\circ}$ do art. 15 da proposição em tela prevê a aplicação do RTT até que seja editada lei regulando definitivamente os efeitos tributários das mudanças nos critérios contábeis, a qual, pretende-se que seja neutra, ou seja, que não afete a carga tributária.”

Eis o estado ideal de coisas a ser preservado pelo indigitado princípio. Segue daí que sua função bloqueadora reside na circunstância de não poder o agente fiscal formalizar obrigações tributárias originárias de circunstâncias ligadas ao novo padrão contábil, ainda que fora do alcance das situações previamente detectáveis do legislador e constantes dos demais dispositivos da Lei $\mathrm{n}^{\circ}$ 11.941/08.

$\mathrm{O}$ indigitado dispositivo, enquanto consagrador de um princípio, estipula um fim a ser perseguido, sem determinar, de antemão, quais os meios para atingi-lo (característica comum dos princípios ${ }^{301}$ ). Não há, pelo menos imediatamente, uma conduta específica descrita, tão presente nas demais regras constantes da Lei nº 11.941/09.

As características das regras estão presentes nos demais artigos da lei, especialmente o caráter retrospectivo (e não prospectivo dos princípios), na medida em que há lá condutas específicas a serem observadas pelos contribuintes e os respectivos meios para alcançar a neutralidade fiscal.

\footnotetext{
300 ÁVILA, Humberto. Teoria dos Princípios. Da definição à aplicação dos princípios jurídicos. 11.ed. São Paulo: Malheiros, 2010. p. 78 e 79.

${ }^{301}$ Cf. ÁVILA, Humberto. Teoria dos Princípios. Da definição à aplicação dos princípios jurídicos. 11.ed. São Paulo: Malheiros, 2010. p. 62.
} 
Em suma, a regra do artigo 15 alberga um verdadeiro princípio, ao passo que os dispositivos seguintes consubstanciam-se em regras, normas que descrevem, de antemão, qual o comportamento adequado à manutenção do estado ideal de coisas a ser preservado.

Conceber o contrário, ou seja, considerar apenas as regras constantes dos demais artigos, ignorando a existência do princípio da neutralidade fiscal, seria o mesmo que ignorar e fazer letra morta o artigo 15; seria o mesmo que dizer que o artigo 15 apenas prenunciaria legislação futura, tendente a, enfim, trazer neutralidade fiscal. Isso não pode ser aceito, sob pena de se negar prescritividade ao direito ${ }^{302}$.

\subsubsection{CASUÍSTICA: A ABRANGÊNCIA DO REGIME TRIBUTÁRIO DE TRANSIÇÃO}

Mesmo com a introdução do RTT pela Lei no 11.941/09 - e consagração daquilo que se convencionou chamar neutralidade tributária -, alguns temas específicos em matéria de IRPJ ainda provocam certa insegurança e não deixam os operadores do direito tributário integralmente tranquilos quanto aos potenciais efeitos fiscais do novo padrão contábil estabelecido no Brasil.

Dentre eles, destacam-se (i) a base de cálculo dos JCP, (ii) a isenção de imposto de renda sobre os dividendos produzidos a partir de 2008 e (ii) a qualificação e quantificação do ágio na aquisição de novos investimentos.

Pretendemos nos próximos tópicos apresentar as possíveis interpretações relacionadas a esses temas, entretanto, advertimos que não cuidaremos, à saciedade, dos institutos ora analisados, nem trazer soluções definitivas, tendo em vista que a análise dos complexos elementos de tais institutos está à margem do escopo do presente trabalho. Nossa intenção - mais modesta - é apenas abordar tais temas sob a perspectiva da neutralidade tributária enquanto princípio e, por outro lado, reafirmar a insuficiência do argumento de que o RTT representaria mera regra - com limitadíssimos efeitos.

\footnotetext{
${ }^{302}$ A prescritividade é qualidade do sistema de comando que o conjunto do sistema do direito positivo apresenta. Tanto é assim que sequer se pode negar prescritividade ao Preâmbulo da Constituição Federal. Nesse sentido, vide Paulo de Barros Carvalho (Fundamentos Jurídicos da Incidência Tributária. 8. ed. São Paulo: Saraiva, 2010. p. 78 e ss.)
} 


\subsection{BASE DE CÁlCULO DOS JUROS SOBRE O CAPITAL PRÓPRIO}

A figura dos JCP foi criada pelo artigo $9^{\circ}$ da Lei $\mathrm{n}^{\circ}$ 9.249/95, representando um instrumento de remuneração dos sócios das pessoas jurídicas. Trata-se de uma alternativa aos tradicionais dividendos, figura neutra do ponto de vista do regime do imposto de renda, cuja distribuição não representa uma despesa dedutível da base de cálculo do IRPJ e tampouco sua recepção exige tributação.

No entanto, os JCP distribuídos ou creditados aos sócios beneficiam fiscalmente a fonte pagadora pela possibilidade de serem considerados despesas dedutíveis até o limite estabelecido pela lei fiscal. Ficam, todavia, sujeitos ao IRRF à alíquota de $15 \%$, sendo considerada antecipação do devido na declaração de rendimentos, no caso de beneficiário pessoa jurídica tributada com base no lucro real e tributação definitiva para os demais casos. Significa isso dizer que a figura dos JCP, a depender da estrutura societária, representa uma alternativa para redução da carga tributária.

Todavia, a distribuição de JCP não tem a amplitude dos dividendos, o que equivale dizer que nem toda a parcela de lucros acumulados pode ficar sujeita a esse específico regime de dedutibilidade. Os JCP dedutíveis da base de cálculo do IRPJ são somente aqueles que resultam da aplicação da TJLP sobre algumas contas do patrimônio líquido.

De toda forma, com o novo regime contábil societário brasileiro inaugurado pela Lei no 11.638/07 e o RTT, surge a questão sobre qual patrimônio líquido servirá de base de cálculo para os JCP: aquele de acordo com as novas regras contábeis ou, pelo contrário, aquele mensurado de acordo com as regras contábeis vigentes em 31 de dezembro de 2007.

Uma primeira linha de interpretação pode ser vista na doutrina do Professor Luís Eduardo Schoueri, que sublinha “(...) a inexistência de um balanço fiscal ao lado daquele levantado para fins societários (..) " para, posteriormente, concluir que “(...) os juros sobre o capital próprio devem ser calculados a partir do patrimônio apurado nos termos da Lei no. 11.638/2007 (...) $)^{\text {303 }}$.

${ }^{303}$ SCHOUERI. Luís Eduardo. Juros sobre o Capital Próprio: Natureza Jurídica e Forma de Apuração diante da 'Nova Contabilidade'”. In: MOSQUERA, Roberto Quiroga. LOPES, Alexsandro Broedel (coords.). Controvérsias Jurídico-Contábeis (aproximações e distanciamentos). Vol. III. São Paulo, Dialética, 2012. p. 190. 
Chegando à mesma conclusão, Carlos Nicacio e Alexandre Querquilli destacam que a neutralidade tributária cingir-se-ia à apuração do lucro tributável, não sendo possível considerar balanços patrimoniais e demonstração de resultados elaborados exclusivamente para fins fiscais e, casuisticamente, para efeitos de cálculo dos $\mathrm{JCP}^{304}$.

É de se notar que essa primeira linha de interpretação concede ao RTT um limitado alcance, o que, a nosso ver, não é consentâneo com o estado ideal de coisas a ser preservado pelo princípio da neutralidade tributária instituída pela Lei no. 11.941/09.

É de se reparar que até mesmo o Professor Luís Eduardo Schoueri assume que o novo padrão contábil, ainda que não tenha alterado a forma de apuração dos JCP, modificou o substrato sobre o qual aquele se faz ${ }^{305}$. Se assim é, forçoso é admitir que há influência das novas regras contábeis sobre o limite de dedutibilidade para fins de IRPJ e, sendo dessa maneira, o princípio da neutralidade tributária não pode aqui ser ignorado, de modo a expurgar todo e qualquer efeito mesmo que inerente ao chamado "substrato" dos JCP.

Noutros termos, temos que a neutralidade tributária deve ser concebida em sua ampla noção - tal como um princípio que ele é -, tendo o legislador querido a manutenção do estado anterior ao novo padrão contábil.

Portanto, é sobre o hipotético balanço patrimonial à luz do padrão contábil vigente em 31 de dezembro de 2007 (não tão hipotético assim após a criação do FCONT) que se deve calcular o JCP, sob pena de comprometimento do estado ideal de coisas a ser preservado pela neutralidade fiscal.

Têm esse mesmo sentir Ian Muniz e Marco Antonio M. Monteiro, para quem: “(...) computar os JCP com base no patrimônio líquido contábil, sem qualquer ajuste, claramente infringe a neutralidade fiscal buscada pela legislação, que claramente busca neutralizar os impactos dos novos métodos e critérios contábeis (...).”306

Ademais, não podemos deslembrar que a figura do JCP, tal qual insculpida pela Lei no. 9.249/96, foi criada com intuito eminentemente tributário (e não societário, ao

\footnotetext{
${ }^{304}$ NICACIO, Carlos N. QUERQUILLI, Alexandre G. Mudanças nas regras contábeis, experiências internacionais e a relativa neutralidade do regime tributário de transição. In: FERNANDES, Edison Carlos. PEIXOTO, Marcelo Magalhães (coords.). Aspectos tributários da nova lei contábil: Lei 11.638/07. São Paulo: MP Ed., 2010. p. 48.

${ }^{305}$ Cf. SCHOUERI. Luís Eduardo. Juros sobre o Capital Próprio: Natureza Jurídica e Forma de Apuração diante da 'Nova Contabilidade'”. In: MOSQUERA, Roberto Quiroga. LOPES, Alexsandro Broedel (coords.). Controvérsias Jurídico-Contábeis (aproximações e distanciamentos). Vol. III. São Paulo, Dialética, 2012. p. 191.

306 MONTEIRO, Marco Antônio M., MUNIZ, Ian. O RTT e a Neutralidade Fiscal. In: ROCHA, Sérgio André (coord). Direito Tributário, Societário e a Reforma da Lei das S/A. Vol. II. São Paulo: Quartier Latin, 2010. p. 278.
} 
contrário dos dividendos). Trata-se de uma figura que contempla uma benesse fiscal, trazendo como consequência a diminuição da base de cálculo do IRPJ. Em outras palavras, trata-se de norma que disciplina a dedutibilidade para efeitos do IRPJ. Sendo assim, mostra-se sem qualquer sentido e repleto de contradições a hipótese de apuração do IRPJ partir do lucro contábil expurgado dos efeitos do novo padrão contábil inaugurado pela Lei $\mathrm{n}^{\circ} 11.638 / 07$ e o cálculo dessa especial forma de dedutibilidade (benesse fiscal) levando-se em conta o novo padrão.

Por fim, não nos parece que o disposto no artigo 59 da Lei no. 11.941/09 - que determina que a conta de ajustes de avaliação patrimonial deve ser excluída para fins de apuração dos JCP - represente um indício de que o legislador quis expressar que o "novo patrimônio líquido" deva servir de base para o JCP. Isso porque, em nossa visão, esse mandamento tem aplicação única e exclusiva para os contribuintes que não aderiram ao RTT para o biênio 2008-2009.

\subsection{ISENÇÃO SOBRE A DISTRIBUIÇÃO DE DIVIDENDOS}

Nos termos do artigo 10 da Lei $\mathrm{n}^{\circ}$ 9.249/95, os lucros ou dividendos calculados com base nos resultados apurados a partir do mês de janeiro de 1996, pagos ou creditados pelas pessoas jurídicas tributadas com base no lucro real, presumido ou arbitrado, não ficarão sujeitos à incidência do imposto de renda na fonte, nem integrarão a base de cálculo do imposto de renda do beneficiário, pessoa física ou jurídica, domiciliado no País ou no exterior.

É de se notar que a legislação tributária concede isenção do imposto de renda sobre os "resultados apurados a partir do mês de janeiro de 1996", assim considerado os dividendos decorrentes do lucro contábil apurado de acordo com a legislação comercial.

Se assim é, poder-se-ia indagar se a isenção sobre os dividendos, em face do RTT, abrangeria somente lucro apurado de acordo com a legislação comercial desde que expurgados os efeitos do novo padrão contábil inaugurado pela Lei nº11.638/07. Noutros termos, a dúvida reside no seguinte ponto: eventual excesso de dividendos oriundos de lucro apurado de acordo com o novo padrão contábil estaria, ou não, albergado pela indigitada isenção?

A questão se coloca porque, no contexto do RTT (em que se almeja neutralidade dos efeitos tributários decorrentes do novo padrão contábil), não haveria como 
se reconhecer, para efeitos meramente fiscais, outro lucro contábil diferente daquele apurado de acordo com a legislação comercial expurgados os efeitos do novo padrão contábil inaugurado pela Lei $\mathrm{n}^{\circ} 11.638 / 07$. Sendo assim, o excesso de dividendos decorrente de lucros de acordo com o novo padrão contábil não mereceria ser objeto de isenção prevista no artigo 10 da Lei ${ }^{\circ}$ 9.249/95.

Todavia, parece-nos que esse não é o melhor entendimento sobre os efeitos da neutralidade fiscal que se busca com o RTT enquanto princípio que é.

Isso porque, segundo pensamos, a neutralidade tributária, numa perspectiva principiológica, implica admitir a convivência harmônica entre os efeitos societários decorrentes do novo padrão contábil e o regime tributário vigente, de maneira a não provocar nenhum impacto tributário. Significa isso admitir a apuração de um lucro societário diferente do padrão revogado, sem que isso implique efeitos tributários decorrentes.

Admitir o contrário (ou seja, a tributação dos dividendos excessivos oriundos de lucro apurado pelo novo padrão contábil) seria o mesmo que assumir que o novo padrão contábil, de fato, impactou do ponto de vista tributário (já que, se tivesse sido mantido o status quo ante, não haveria que se falar em imposto de renda), fazendo tabula rasa a noção de neutralidade tributária enquanto princípio de que falamos anteriormente.

\subsection{MENSURAÇÃO DO ÁGIO BASEADO EM RENTABILIDADE FUTURA}

O tema das aquisições de participações societárias tem se revelado, nos últimos anos, dos mais férteis para a pesquisa jurídica no campo tributário, chamando atenção especialmente dos que militam na seara da tributação da renda.

Dentre os vários aspectos que poderiam ser abordados, interessa-nos neste momento a determinação constante do CPC 15 (combinações de negócios) quanto ao reconhecimento e mensuração do ágio por rentabilidade futura, que em, aspectos relevantes, distancia-se da forma como os contribuintes abordavam a questão até então. Note-se que, mesmo num contexto de neutralidade fiscal introduzida pelo RTT, discute-se a influência do CPC 15 no tratamento do ágio para efeitos fiscais.

Com efeito, antes do novo regime contábil inaugurado pela Lei no. 11.638/07, no contexto de uma aquisição de um investimento relevante em coligada ou controlada, a 
investidora deveria segregar em sua contabilidade o custo de aquisição em duas parcelas, quais sejam: (i) o valor do patrimônio líquido na época de aquisição; e (ii) ágio ou deságio na aquisição, que será a diferença entre o custo de aquisição do investimento e o valor acima (artigo 385 do RIR/99).

O ágio ou o deságio, nos termos da legislação fiscal ${ }^{307}$, poderiam ser justificados pela mais ou menos valia econômica dos ativos em relação ao valor contábil, pela projeção de rentabilidade futura, além de fundo de comércio, intangíveis e outras razões econômicas. Sendo o ágio justificado pela rentabilidade da coligada ou controlada com base em resultados nos exercícios futuros, a investidora, se absorver o patrimônio da investida ou for absorvida por ela, poderá amortizar o ágio à razão de um sessenta avos, no máximo, para cada mês do período de apuração (artigo 386, III, do RIR/99).

Ocorre, porém, que, com a superveniência do CPC 15, o ágio não mais passou a ser mensurado pela fórmula desenhada pelo artigo 385 do RIR/99. Nesse sentido, o ágio representa hoje, grosso modo, a diferença a maior entre o valor de aquisição do investimento e o valor líquido avaliado pelo valor justo, na data da aquisição, dos ativos identificáveis adquiridos e dos passivos assumidos (item 35 do CPC 15).

É de se notar que o regime anterior não indicava uma ordem predeterminada de alocação de justificativa do ágio, razão pela qual não era incomum, na prática empresarial, o ágio (diferença entre o valor do patrimônio liquido proporcional da investida e o valor da aquisição) ser integralmente justificado pela projeção de rentabilidade futura, sendo ignorado, para efeitos de contabilização e efeitos fiscais, eventual diferença entre o valor contábil e o econômico de bens do ativo da investida.

Todavia, no regime estabelecido pela CPC 15, com a necessidade de avaliar a valor justo dos ativos líquidos dos passivos, o mesmo não ocorre, uma vez que a mensuração do ágio baseado na rentabilidade futura é precedida de uma avaliação dos ativos e passivos da investida.

Assim, a questão que se impõe é se, para efeitos fiscais (no contexto do RTT) e a despeito da nova metodologia imposta pelo CPC 15, a mensuração do ágio baseado na rentabilidade futura poderia ser levada a efeito desconsiderando-se a avaliação dos ativos e

\footnotetext{
${ }^{307}$ Como bem lembra Edmar Oliveira Andrade Filho: "A Lei n. 6.404/76 é absolutamente omissa a respeito da apuração do ágio ou deságio, tanto que essas figuras foram introduzidas no ordenamento jurídico por intermédio do Decreto-lei n. 1.598/77. A CVM tratou do assunto de modo melhor sistematizado somente em 1996, quando editou a Instrução CVM n. $257 / 96$ (...)" (O direito contábil e a disciplina jurídica das demonstrações financeiras. São Paulo: Prognose Editora, 2010. p. 160.)
} 
passivos, ou, de modo contrário, se o valor dos ativos líquidos dos passivos a valor justo deveria ser o referencial para se mensurar o ágio baseado na rentabilidade futura.

Discorrendo sobre o tema, Ana Cláudia Akie Utumi opina:

“(...) não é mais possível adotar uma justificativa econômica para fins de atendimento do CPC 15, e outra justificativa econômica para fins tributários. A justificativa econômica deve ser única, de tal maneira que, diferentemente do que ocorria no passado, para fins tributários não é mais possível justificar $100 \%$ do ágio com base na lucratividade futura da empresa." 308

Essa corrente se agarra na premissa de que a exigência constante do CPC 15 quanto à avaliação dos ativos e passivos a valor justo revelaria inequivocamente um afastamento da rentabilidade futura da empresa como fundamentação econômica do ágio. Noutras palavras, não mais se justificaria o ágio totalmente fundamentado na rentabilidade futura da empresa se restar comprovado que o valor líquido dos ativos líquidos dos passivos é superior ao patrimônio líquido. Nesse sentido, o ágio, para efeitos fiscais, deveria ser desdobrado em duas parcelas, quais sejam: (i) valor de mercado de bens do ativo e (ii) rentabilidade futura.

Todavia, parece-nos que essa não é a melhor conclusão, tendo em vista dois argumentos que, em nossa visão, não podem ser ignorados quando da análise do presente tema.

Em primeiro lugar, a legislação tributária não impõe uma ordem preestabelecida de alocação do ágio entre as alternativas arroladas pelo artigo 385 do RIR/99. Luciana Rosanova Galhardo e Jorge Ney de Figueirêdo Lopes Júnior salientam a esse respeito que:

“(...) não existe na legislação fiscal nenhuma indicação de como o ágio pago na aquisição de participação societária deva ser alocada a cada um desses três fundamentos. Ao contrário, a legislação diz expressamente que 'o lançamento do ágio ou deságio deverá indicar, dentre os seguintes, seu fundamento econômico: (...)'. Não há, portanto, na legislação tributária, qualquer indicação de hierarquia ou outra forma de preferência na ordem de alocação do ágio." 309

\footnotetext{
${ }^{308}$ UTUMI, Ana Cláudia Akie. O ágio nas Operações de Fusões e Aquisições em Face das Novas Regras Contábeis. In: MOSQUERA, Roberto Quiroga. LOPES, Alexsandro Broedel (coords.). Controvérsias Jurídico-Contábeis (aproximações e distanciamentos). São Paulo, Dialética, 2010. P. 112.

309 GALHARDO, Luciana Rosanova, LOPES JÚNIOR, Jorge Ney de Figueirêdo, As Novas Normas Contábeis e a Amortização Fiscal do Ágio. In: MOSQUERA, Roberto Quiroga. LOPES, Alexsandro Broedel (coords.). Controvérsias Jurídico-Contábeis (aproximações e distanciamentos). São Paulo, Dialética, 2010. P. 234.
} 
Em segundo lugar, parece-nos que a lei tributária impõe que o ágio seja fundamentando pelo motivo determinante que guia o adquirente na aquisição do investimento, a despeito da possibilidade de, numa mesma situação, coexistirem mais de uma hipótese elencada no artigo 385 do RIR/99.

Nesse sentido, imaginemos a seguinte situação: numa dada aquisição de empresa, o valor contábil do ativo é subavaliado se comparado com o valor de mercado, porém, o adquirente intenta obter resultados positivos por meio da consecução do objeto social da empresa adquirida - e não com a alienação de seus ativos. Nesse caso, parece-nos que, para efeitos fiscais, eventual ágio deverá ser fundamentado exclusivamente pela rentabilidade futura (motivo determinante para o adquirente realizar o negócio), sem nenhuma alocação para o fundamento do inciso I do $§ 2^{\circ}$ do artigo 385 do RIR/99 (valor de mercado de bens do ativo da coligada ou controlada superior ou inferior ao custo registrado na sua contabilidade).

Luis Eduardo Schoueri explorou de maneira didática essa linha argumentativa. Para o Professor Titular da USP:

“(...) Nos casos em que o comprador paga ágio com o fundamento na rentabilidade futura da investida não se cogita de investigar o valor que poderia receber ao alienar um ou outro bem da empresa. Pelo contrário, tal fundamento pressupõe que o investimento não será desfeito, já que o lucro será obtido não com sua realização, mas com a rentabilidade futura da investida." 310

Portanto, a determinação do CPC 15 para que os ativos sejam avaliados a valor justo não significa equivalência ao fundamento econômico constante do inciso $\mathrm{I}$ do $\S 2^{\circ}$ do artigo 385 do RIR/99. Para efeitos fiscais importa o motivo determinante para aquisição do investimento. Caso esse seja a expectativa de rentabilidade futura da empresa (i.e., pela execução de seu objeto social), eventual ágio poderá ser exclusivamente fundamentado pelo inciso II do $\$ 2^{\circ}$ do artigo 385 do RIR/99 (valor de rentabilidade da coligada ou controlada, com base em previsão dos resultados nos exercícios futuros).

Assim, na prevalência do RTT, não poderá o fisco desqualificar, para efeitos fiscais, o fundamento do ágio baseado na rentabilidade futura, para, em certa medida, alocar o fundamento baseado no valor de mercado dos ativos na hipótese aventada acima.

${ }^{310}$ SCHOUERI, Luis Eduardo. Tratamento tributário do ágio: considerações sobre seu fundamento. Revista de Direito Tributário no. 100. São Paulo: Malheiros. P. 169-170. 


\subsubsection{O PRINCÍPIO DA LEGALIDADE TRIBUTÁRIA E OS MÉTODOS E CRITÉRIOS CONTÁBEIS EMANADOS DE AUTORIDADES CONTÁBEIS}

Como comentado alhures, a LSA consagra uma diversidade de critérios e métodos contábeis, entretanto, não é difícil supor que o texto legal aponte, na maioria dos casos, apenas fundamentais diretrizes, não detalhando à saciedade todo e qualquer procedimento de ordem contábil. Tanto isso é verdade que a própria legislação societária faz referência a normas contábeis expedidas por outros órgãos infralegais, como a $\mathrm{CVM}^{311}$, bem assim a princípios de contabilidade geralmente aceitos.

Diante desse cenário, insta-nos investigar se a apuração do IRPJ influenciada por determinações de nível infralegal (pronunciamentos da CVM, CPC, etc.) seria compatível com o primado da legalidade tributária.

Nesse aspecto, deve-se mencionar preliminarmente que o princípio da legalidade tributária tem sido submetido à revisão de seu conteúdo e alcance pela doutrina e jurisprudência. Se antes se propugnava, de maneira incisiva e inflexível, pela legalidade numa concepção positivista-formalista (daí expressões como legalidade absoluta e tipicidade fechada), agora se fala em revisão da reserva legal, numa concepção nãopositivista $^{312}$.

Com efeito, parece-nos apropriado aludir ao caso da Contribuição ao Seguro de Acidentes do Trabalho - SAT, julgado pelo Supremo Tribunal Federal. Para tal contribuição, instituída pela Lei $\mathrm{n}^{\circ} 8.212 / 91$, foram estabelecidas diferentes alíquotas tendo em conta diferentes graus de risco ao trabalhador. Todavia, a precisa definição do grau de risco fora avocada pela Administração, sendo determinada de acordo com a Classificação Nacional de Atividades Econômicas - CNAE.

Instada a se manifestar, nossa Corte Máxima, quando do julgamento do RE 343.446-SC, definiu que:

"O fato de a lei deixar para o regulamento a complementação dos conceitos de "atividade preponderante" e grau de risco leve, médio e grave", não implica ofensa ao princípio da legalidade genérica, $\mathrm{CF}$, art. $5^{\circ}$, II e da legalidade tributária, CF, art. 150, I."

${ }^{311}$ Art. 177, $\S 330$ a 5o, da LSA.

312 Cf. TORRES, Ricardo Lobo. Tratado de Direito Constitucional Financeiro e Tributário. Valores e Princípios Constitucionais Tributários. Vol. II. Rio de Janeiro, Editora Renovar: 2005. p. 420. 
Ressalvou-se, entretanto, que a Administração poderia exercer plenamente o poder regulamentar desde que não violasse o sentido emanado do texto legal. Assim, consoante se infere do citado julgamento, "se o regulamento vai além do conteúdo da lei, a questão não é de inconstitucionalidade, mas de ilegalidade, matéria que não integra o contencioso constitucional."

Esse precedente é importante para enfatizar que o Direito Tributário brasileiro, ainda que caracterizado pela rigidez desenhada pela $\mathrm{CF} / 88$, não tão inflexível a ponto de se afirmar que as autoridades administrativas não detêm um mínimo de poder de inovação no sistema do direito positivo. Nos dizeres de Ricardo Lobo Torres, “(...) não se pode perder de vista que o direito tributário, que se estrutura sobretudo a partir do discurso do legislador, necessita da complementação harmoniosa do trabalho da interpretação administrativa e judicial." 313 O contrário seria abrir caminhos a uma hiperinflação legislativa, tão danosa para a segurança jurídica.

Destarte, seguindo essa linha, quer-nos parecer que a obediência, para fins de apuração do IRPJ, aos pronunciamentos da CVM ou do CPC não violaria, prima facie, o princípio da legalidade tributária. Isso quando (e somente quando) os pronunciamentos emitidos por autoridades contábeis (como a CVM e o CPC) estiverem amparados pelas diretrizes consagradas na LSA.

De outra banda, para efeitos de apuração do IRPJ, não devem ser levados em conta pronunciamentos inovadores ou destoantes das diretrizes acolhidas no texto da LSA. Nesse aspecto, somos da mesma opinião de Paulo Cezar Aragão e Sérgio André Rocha ao doutrinarem que “(...) a incidência fiscal não pode ficar à disposição das mudanças contábeis estabelecidas pelo CPC, sob pena de violação ao princípio da legalidade.”314

Exemplo eloquente disso é que o lucro que deve servir de ponto de partida para apuração do IRPJ é aquele suportado pela DRE - e não pela DRA. Enquanto o primeiro é expressamente previsto e disciplinado pela LSA, o segundo é relatório contábil obrigatório nos termos do CPC 26.

\footnotetext{
313 TORRES, Ricardo Lobo. Tratado de Direito Constitucional Financeiro e Tributário. Valores e Princípios Constitucionais Tributários. Vol. II. Rio de Janeiro, Editora Renovar: 2005. p. 463.

314 ARAGÃ̃, Paulo Cezar, ROCHA, Sergio André. Alteração dos Padrões Contábeis Brasileiros: A Neutralidade Fiscal Transitória, "Deslegalização" da Contabilidade e o Princípio da Legalidade Tributária. In: ROCHA, Sergio André (cood.). Direito Tributário, Societário e a Reforma da Lei das S/A. Vol. II. São Paulo: Quartier Latin, 2010. p. 511.
} 


\section{CONFRONTO ENTRE RENDA CONSTITUCIONALMENTE TRIBUTÁVEL E LUCRO CONTÁBIL}

\subsection{FUNÇÃO COMPARATIVA dA BASE DE CÁlCULO: O ASPECTO MATERIAL CONSTITUCIONALMENTE PRESSUPOSTO E O INSTRUMENTAL CONTÁBIL}

Concluímos, no capítulo 2, estar o aspecto material do imposto de renda necessariamente ligado ao aumento do patrimônio considerado entre um marco temporal e outro. Para que essa noção seja compatível com a capacidade contributiva objetiva, o patrimônio deve, também necessariamente, ser concebido em sua acepção jurídica, conforme destacamos no capítulo 3. Já no capítulo 5, vimos que a juridicização da contabilidade pelo regime do IRPJ (por meio de remissão ao Direito Societário) tem sido utilizada como um expediente no processo de apuração da base de cálculo.

Se assim é, interessa-nos investigar se, em face da disciplina constitucional do imposto de renda e da atual perspectiva da contabilidade (juridicizada pelo Direito Societário), o legislador ordinário poderia estabelecer o modelo de dependência total, isto é, adotar o lucro contábil-societário como base de cálculo do IRPJ sem nenhuma correção ou limitação no seu processo de determinação, como acontece, v.g., na Alemanha e na Áustria $^{315}$. Caso negativo, surge a indagação sobre o norte a ser seguido pelo legislador quanto à correção do lucro contábil-societário para que a base de cálculo do IRPJ confirme o aspecto material pressuposto pela $\mathrm{CF} / 88$. Eis nosso desafio no presente e derradeiro capítulo.

Pois bem. É importante principiar afirmando que o patrimônio não passa de uma abstração, uma realidade intangível, existente apenas no plano do imaginário humano, que não se apalpa ou se observa facilmente na natureza. Tangíveis, no máximo, são os títulos que atestam os direitos e deveres integrantes do patrimônio (como a certidão de registro de imóveis, certificado de depósito bancário, instrumentos de contrato, etc.) e os próprios bens que representam o objeto das relações jurídicas (imóveis, veículos, etc.). De

${ }^{315}$ Cf. POLIZELLI, Victor Borges. Balanço Comercial e Balanço Fiscal: Relações entre o Direito Contábil e o Direito Tributário e o Modelo Adotado pelo Brasil. in: Direito Tributário Atual $\mathrm{n}^{\circ} 24$. Coords. BONILHA, Paulo Celso Bergstrom, COSTA, Alcides Jorge, SCHOUERI, Luís Eduardo, ZILVETTI, Fernando Aurélio. São Paulo: Dialética, 2010. p. 593. p. 603. 
todo modo, as relações jurídicas que compõem o patrimônio continuam a ser entidades intangíveis e abstratas.

Pudera! Patrimônio, nas palavras de José Luiz Bulhões Pedreira, “(...) é o conjunto de direitos e obrigações apreciáveis economicamente que se acham inter-

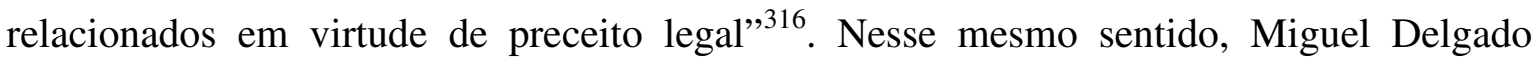
Gutierrez, para quem: “(...) é composto de dois subconjuntos: a) ativo patrimonial, cujos elementos são os direitos, e b) o passivo patrimonial, cujos elementos são as obrigações." 317 .

Se assim é, o aspecto material do imposto de renda (= aumento de patrimônio verificado entre dois lapsos temporais) está afeto, grosso modo, ao saldo positivo e líquido do conjunto de novas relações jurídicas (i.e., surgidas entre o marco inicial e final) em que o sujeito integra o polo ativo (direitos) e das novas relações jurídicas em que esse mesmo sujeito integra o polo passivo (deveres jurídicos) ${ }^{318}$.

Nesse plano meramente abstrato, a ocorrência do aspecto material do imposto de renda originaria do produto de um hipotético inventário que relacionasse todos os elementos acima mencionados. Exemplificando, nesse inventário ideal, teríamos:

\section{Inventário de direitos e deveres surgidos no período:}

\section{Direitos sobre:}

(+) valores monetários em caixa no importe de \$100;

(+) participações societárias na companhia $Y$;

(+) crédito oriundo de vendas a prazo de 10 unidades de

mercadorias;

(+) propriedade de 15 unidades de mercadorias;

(+) propriedade de imóvel situado na Rua X;

Deveres sobre:

\footnotetext{
${ }^{316}$ PEDREIRA, José Luiz Bulhões. Imposto sobre a Renda - Pessoas Jurídicas. Vol. I. Rio de Janeiro: Justec, 1979. p. 244.

${ }^{317}$ GUTIERREZ, Miguel Delgado. O Imposto de Renda e os Princípios da Generalidade, da Universalidade e da Progressividade. Tese. Doutorado. Universidade de São Paulo, 2009. 103.

${ }^{318}$ Dissemos "grosso modo" eis que existentes outros elementos importantes para o exato reconhecimento do aspecto material do impostos de renda, os quais, por não serem relevantes para o prosseguimento do presente capítulo, não serão abordados aqui. Poderíamos citar, por exemplo, os direitos que comporiam o patrimônio se não fossem consumidos durante o período (renda consumida), as transferências de capital, os deveres ligados ao mero consumo, etc.
} 
(-) operação de empréstimo de $\$ 60$ concedido por Banco

$A B C$;

(-) compra a prazo de 5 unidades de mercadorias.

RESULTADO = ASPECTO MATERIAL DO IMPOSTO DE RENDA

Todavia, por mais que as afirmações acima sejam procedentes, são elas insuficientes para, de imediato e sem nenhum esforço adicional, chegar-se à base de cálculo do imposto de renda. Vale dizer, do patrimônio - do alto de seu plano abstrato - não exsurge imediatamente uma expressão monetária. Isso não é de causar surpresa porque, como nos ensina Paulo de Barros Carvalho, discorrendo sobre a relação entre aspecto material e base de cálculo, “(...) os fatos não são, enquanto tais, mensuráveis na sua integralidade, no seu todo." 319

Torna-se imprescindível um esforço adicional. É necessário - partindo do patrimônio em sua abstração - chegar a outro plano, a uma nova realidade, a uma diferente linguagem. Objetivamente falando, deve-se dimensionar monetariamente o aspecto material do imposto de renda.

Para tanto, como bem complementa o citado Professor Emérito da USP e da PUC/SP, o legislador deve apontar, dentre as possibilidades eventualmente existentes para dimensionar quantitativamente o fato, aquela que capte "(...) aspectos inerentes à conduta ou ao objeto da conduta que se aloja no miolo da conjuntura do mundo físico., ${ }^{320}$ Decorre disso a circunstância de que a base de cálculo tem função comparativa, porquanto, posta diante do critério material da hipótese, é capaz de confirmá-lo, infirmá-lo ou afirmar aquilo que consta no texto da lei de modo obscuro. Será infirmado se houver manifesta incompatibilidade entre a grandeza eleita e o acontecimento que o legislador declara como a medula da previsão fáctica ${ }^{321}$.

Portanto, não basta aquele inventário de que falamos antes, arrolando todos os direitos e deveres surgidos durante o período. Assim como não basta apenas a afirmação de que o aspecto material do imposto de renda seja o acréscimo patrimonial verificado entre dois lapsos temporais. É necessário quantificar e dimensionar o patrimônio

\footnotetext{
${ }^{319}$ CARVALHO, Paulo de Barros. Curso de Direito Tributário. 17. ed. São Paulo: Saraiva, 2005. p. 332. ${ }^{320}$ CARVALHO, Paulo de Barros. Curso de Direito Tributário. 17. ed. São Paulo: Saraiva, 2005. p. 332.

321 Cf. CARVALHO, Paulo de Barros. Curso de Direito Tributário. 17. ed. São Paulo: Saraiva, 2005. ps. 335 e 337. Observe-se que não trabalharemos com a última hipótese (afirmação), posto que o critério material do imposto de renda extraído da $\mathrm{CF} / 88$ não pode ser considerado obscuro, ainda que contenham algum grau de indeterminabilidade semântica.
} 
monetariamente ${ }^{322}$. Torna-se imprescindível que essa realidade (intangível) da universalidade de direitos e deveres (patrimônio) seja destruída e reconstruída numa nova linguagem, apta a expressar o aumento de patrimônio em unidades monetárias.

Daí porque a contabilidade ter sido utilizada como instrumento para mensuração da base de cálculo do IRPJ. Com bem salienta Edvaldo Brito, essa linguagem, ao contrário da jurídica, é formalizada, ou seja: em lugar das palavras da língua natural que têm conteúdos semânticos capazes de referenciarem situações concretas do mundo, colocassem símbolos aptos para recolherem qualquer coisa ou situação concreta de qualquer universo $^{323}$. A linguagem contábil, destarte, produz uma representação gráfica da situação "patrimonial" (no sentido econômico-informacional), contendo expressões monetárias.

Dados os limites deste trabalho, não temos a pretensão de estabelecer um modelo ideal de quantificação monetária do acréscimo de patrimônio, apto a servir de base de cálculo do imposto de renda. Não pretendemos reinventar a roda. Nosso objetivo - mais modesto - consiste em avaliar em que medida o instrumento contábil (na sua atual perspectiva: a econômico-informacional) confirma, ou infirma, o aspecto material do imposto de renda, uma vez que ele tem sido tradicionalmente utilizado como ponto de partida para identificação da base de cálculo do IRPJ.

Noutras palavras, não desenvolveremos um modelo de quantificação monetária do acréscimo de patrimônio, mas criticaremos o modelo atualmente existente (a contabilidade em sua atual perspectiva) como instrumento para quantificar a base de cálculo do IRPJ.

Para tanto, nossa análise crítica partirá das etapas que constituem o processo contábil, com vistas a apurar se são, ou não, convergentes com o aspecto material do imposto de renda.

Assim, é de todo fundamental que se expresse que as aludidas etapas, conforme nos ensinam Alexsandro Broedel Lopes e Eliseu Martins, são:

(i) Reconhecimento: classificação da ação de natureza econômica (ativo, passivo, etc.);

\footnotetext{
322 “(...) a moeda é um mero instrumento da economia, usado como fator de medida genérica e universal dos direitos patrimoniais, como ocorre com o metro para medir distâncias, o quilograma para medir o peso das coisas, e o litro para medir líquidos, etc." (RENCK, Renato Romeu. Imposto de renda da pessoa jurídica: critérios constitucionais de apuração da base de cálculo: uma proposta de interpretação sistemática do Direito. Porto Alegre: Livraria do Advogado, 2001. p. 110.)

${ }^{323}$ Cf. BRITO, Edvaldo. O excesso de retirada tributável como acréscimo patrimonial. In: MARTINS, Ives Gandra da Silva (Coord.). Imposto de Renda: conceitos, princípios, comentários. 2.ed. São Paulo: Atlas, 1996. p. 112.
} 
(ii) Mensuração: definição de sua base de mensuração (custo histórico, custo histórico corrigido, valor de mercado, etc.); e

(iii) Evidenciação: explicação aos usuários externos da forma como a entidade reconheceu e mensurou as ações ${ }^{324}$.

Dentre essas etapas, interessa-nos com mais vigor as duas primeiras, já que a última consubstancia ato de interesse especifico da contabilidade, visando, em última análise, a prestação de informações aos usuários dela.

\subsection{OS ATOS DE RECONHECIMENTO E DE MENSURAÇÃO PELA CONTABILIDADE E O TESTE DA CONFIRMAÇÃO DO ASPECTO MATERIAL DO IMPOSTO DE RENDA}

Ponto central no tema do reconhecimento e da mensuração pela contabilidade dos elementos que compõem o patrimônio da entidade é o estudo do ativo, o qual, inexoravelmente, terá reflexos na determinação do patrimônio líquido. Tanto isso é verdade que Sérgio de Iudícibus chega a afirmar que "é tão importante o estudo do ativo que poderíamos dizer que é o capítulo fundamental da Contabilidade, porque à sua definição e mensuração está ligada a multiplicidade de relacionamentos contábeis que envolvem receitas e despesas." 325

Pois bem. Condizente com a atual perspectiva da contabilidade (information approach), o ativo pode ser conceituado como recurso controlado pela entidade como resultado de eventos passados e do qual se espera que resultem futuros benefícios econômicos para a entidade ${ }^{326}$.

Elementos-chave desse conceito e que nos interessam mais diretamente por ocasião do presente estudo são:

(i) recursos, termo utilizado em sentido amplo para incluir tanto tangíveis quanto intangíveis ${ }^{327}$;

(ii) controle, em substituição à propriedade. Significa dizer que determinado recurso poderá integrar o ativo de uma entidade, ou mesmo dele ser excluído,

\footnotetext{
${ }^{324}$ Cf. LOPES, Alexsandro Broedel. MARTINS, Eliseu. Teoria da Contabilidade: uma nova abordagem. São Paulo, Atlas, 2005. p. 52.

${ }^{325}$ IUDÍCIBUS, Sérgio de. Teoria da contabilidade. 10.ed. São Paulo: Atlas, 2010. p. 123.

${ }^{326}$ Cf. Item 49 do Pronunciamento CPC sobre a Estrutura Conceitual para Elaboração e Apresentação das Demonstrações Contábeis.

${ }^{327}$ Cf. IUDÍCIBUS, Sérgio de. Teoria da contabilidade. 10.ed. São Paulo: Atlas, 2010. p. 125.
} 
independentemente do título de propriedade. Por outro lado, a posse também não é determinante para o reconhecimento de um ativo ${ }^{328}$. O controle, na verdade, deve ser concebido como intimamente relacionado ao item seguinte, isto é, para que um recurso possa ser reconhecido como ativo, a entidade deve ter o controle sobre os futuros benefícios econômicos ${ }^{329}$; e

(iii) resultem futuros benefícios econômicos, assim considerado seu potencial em contribuir, direta ou indiretamente, para o fluxo de caixa ou equivalentes de caixa para a entidade ${ }^{330}$.

Da definição de ativo, infere-se a grande preocupação da atual perspectiva da contabilidade no que tange à prestação de informação sobre a potencialidade de fluxo de caixa futuro. Resumindo o ativo na perspectiva contábil de maneira simples (mas extremamente eficiente), Sérgio de Iudícibus sentencia: “Todo ativo representa, mediata ou imediatamente, direta ou indiretamente, uma promessa futura de caixa.",331

A potencialidade de geração futura de caixa ou equivalente é um requisito essencial para o reconhecimento e a mensuração contábil do ativo. Trata-se de um verdadeiro norte para a contabilidade reconhecer o recurso como tal. E assim é porque, na atual perspectiva da contabilidade (information approach), privilegia-se a prestação de informação sobre a geração de caixa futuro como instrumento para o usuário tomar decisões sobre a entidade.

Em face disso, a contabilidade se vê longe da "missão" de bem retratar o ativo patrimonial, tal como concebido numa perspectiva jurídica (direito suportado por preceito legal, elemento de uma relação jurídica).

Destarte, do cotejo entre o ativo contábil e o ativo patrimonial-jurídico, podemos nos deparar com situações nas quais determinado recurso será reconhecido como ativo contábil, porém, não como ativo patrimonial-jurídico. E vice-versa.

Valemo-nos do goodwill como um primeiro exemplo. No contexto das combinações de negócios (business combinations, disciplinado contabilmente pelo Pronunciamento CPC 15), trata-se do excesso de valor pela aquisição de um negócio sobre o valor dos ativos líquidos dos passivos (individualmente considerados), o qual é

\footnotetext{
${ }^{328}$ Nesse sentido, Sérgio de Iudícibus atesta: "Podemos ter adquirido um ativo e ele estar ainda em trânsito, não chegou, fisicamente, em nossa entidade, mas, nem por isso, deixa de ser ativo." (IUDÍCIBUS, Sérgio de. Teoria da contabilidade. 10.ed. São Paulo: Atlas, 2010. p. 125.)

${ }^{329}$ Cf. item 57 do Pronunciamento CPC sobre a Estrutura Conceitual para Elaboração e Apresentação das Demonstrações Contábeis.

${ }^{330}$ Cf. item 53 do Pronunciamento CPC sobre a Estrutura Conceitual para Elaboração e Apresentação das Demonstrações Contábeis.

${ }^{331}$ IUDÍCIBUS, Sérgio de. Teoria da contabilidade. 10.ed. São Paulo: Atlas, 2010. p. 138.
} 
justificado pela expectativa de rentabilidade futura gerada, muitas vezes, pela interação e integração desses ativos. Em suma, pode ser a mais-valia pela união do conjunto, superior ao valor econômico dos elementos isoladamente considerados.

Graficamente representando, teríamos a seguinte situação de comparação entre o reconhecimento contábil e o fenômeno patrimonial jurídico:

\begin{tabular}{|l|l|}
\hline $\begin{array}{l}\text { Jurídico: } \\
\text { Direito de propriedade sobre ações da }\end{array}$ & $\begin{array}{l}\text { Contábil: } \\
\text { empresa X. Valor justo dos ativos identificáveis } \\
\end{array}$ \\
& $\begin{array}{l}\text { adquiridos líquidos dos passivos assumidos; } \\
- \text { Goodwill }\end{array}$ \\
\hline
\end{tabular}

Note-se que o goodwill, enquanto elemento abstrato captado pela contabilidade, não encontra correspondência no âmbito das relações jurídicas que compõem o patrimônio (jurídico). Nas palavras de Edmar Oliveira Andrade Filho, "o ágio não é alienável, isto é, não pode ser transferido porque a investidora não detém um título jurídico sobre ele. ${ }^{332}$ A despeito disso, a contabilidade, cumprindo seu papel informacional, segrega o valor de aquisição do negócio em duas vertentes: o valor dos ativos líquidos dos passivos isoladamente considerados e o valor da mais-valia decorrente da interação e integração desses elementos (goodwill). Observe-se que, nesse caso, a dicotomia entre a visão contábil e a jurídica está no campo do reconhecimento (segregação do ativo em duas partes pela contabilidade), muito embora o campo da mensuração como um todo possa até ser compatível com o jurídico, eis que os dois ativos contábeis, no conjunto, são contabilizados pelo valor da aquisição do negócio.

Noutros exemplos, o contábil se distancia do jurídico tanto no ato de reconhecimento, quanto no da mensuração.

Valemo-nos do Pronunciamento CPC 32 (Tributos sobre o lucro), que regula o reconhecimento do ativo fiscal diferido decorrente de diferenças temporárias dedutíveis ou prejuízos fiscais de IRPJ e contribuição social. Juridicamente considerado, não há como reputar o prejuízo fiscal como crédito (direito) contra a União, como se fosse um indébito tributário. Em realidade, a utilização do prejuízo fiscal (abatimento da base de cálculo do IRPJ) está condicionada ao surgimento de lucro tributável. Trata-se, no máximo, de uma expectativa de direito. Isso não impede, todavia, que a contabilidade reconheça o ativo

332 ANDRADE FILHO, Edmar Oliveira. O direito contábil e a disciplina jurídica das demonstrações financeiras. São Paulo: Prognose Editora, 2010. p. 196. 
fiscal diferido como instrumento para prever o fluxo de caixa, atendendo seu propósito no contexto do information approach.

Graficamente representando, teríamos a seguinte situação de comparação entre o reconhecimento contábil e o patrimônio jurídico:

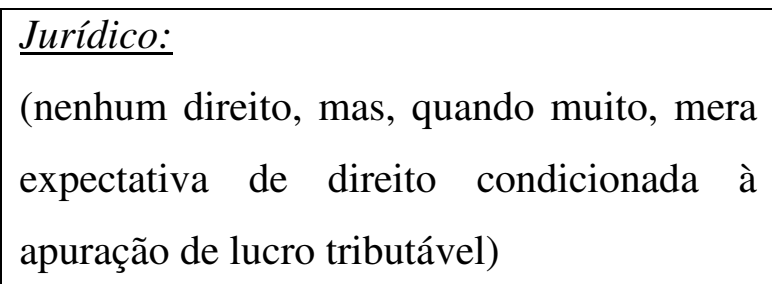

De modo inverso, poderíamos apontar o caso de um bem imóvel tombado pelo patrimônio histórico, que, por conta dessa circunstância, estaria inviabilizado de receber benfeitorias aptas a atender as necessidades da entidade. Imaginemos também que esse mesmo imóvel teve, por essa mesma circunstância, perdido valor de mercado, não havendo perspectivas de alienação. Exatamente por isso, a contabilidade não reconheceria esse imóvel como ativo, embora, do ponto de vista jurídico, ainda exista o direito de propriedade.

Graficamente representando, teríamos a seguinte situação de comparação entre o reconhecimento contábil e o patrimônio jurídico:

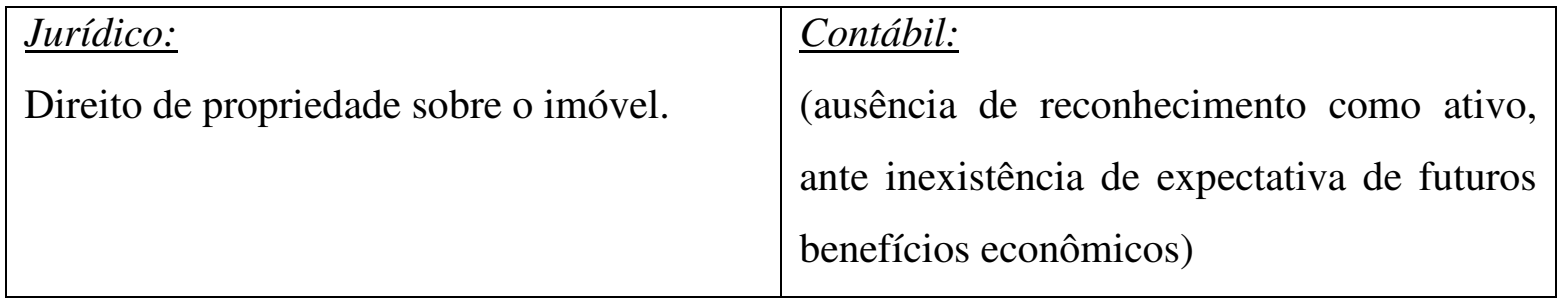

Com efeito, a partir dessa análise do ativo contábil e sua comparação com o ativo patrimonial-jurídico, já podemos concluir que o modelo de dependência total não poderia ser adotado no Brasil. A utilização do expediente contábil para fins de determinação da base de cálculo do IRPJ, quando acolhida, merece sofrer significativos ajustes da legislação tributária, sob pena de se dimensionar o fato tributário de maneira destoante de sua realidade jurídica.

Enquanto a contabilidade, em sua perspectiva atual (information approach), tem seus olhos voltados para o fluxo futuro de caixa, a tributação da renda deve projetar suas forças para os êxitos já alcançados (no presente, com o perdão da redundância), sob 
pena de colidir com o estado ideal de coisas a ser preservado pelo princípio da capacidade contributiva.

Carlos Nicacio e Alexandre Querquilli tiveram essa mesma sensibilidade, ao discorrerem da seguinte forma:

“(...) até que ponto é desejável a utilização de demonstrações contábeis preparadas nesses moldes para fins de apuração de tributos? Esta questão é relevante, pois o objetivo do investidor externo é predizer a magnitude dos fluxos de caixa futuros da entidade e os riscos associados para tomar decisões financeiras. Esse enfoque claramente não tem por prioridade a apuração de tributos, cujas legislações podem, eventualmente, aproveitar-se de conceitos contábeis que sejam considerados úteis. Além disso, os procedimentos de fiscalização têm um enfoque para o passado, com relativa indiferença com o futuro da empresa." 333

É a tributação do patrimônio (jurídico) que se alinha com o êxito já alcançado e não perspectivas de geração futura de caixa. A mensuração, pela contabilidade, de fenômeno alheio a isso infirmaria o aspecto material do imposto de renda. A tributação da renda deve estar afeta ao conjunto de novas relações jurídicas (i.e., surgidas entre o marco inicial e final) em que o sujeito integra o polo ativo (direitos) e das novas relações jurídicas em que esse mesmo sujeito integra o polo passivo (deveres jurídicos) ${ }^{334}$. Tais relações jurídicas devem ser compreendidas sob a ótica do direito - e não da representação gráfica preparada pela contabilidade.

Nas palavras de Ricardo Lacaz Martins, "no caso das pessoas jurídicas, a apuração do lucro real deve pautar-se pela conformação jurídica dos atos e fatos praticados e não por sua repercussão econômica." 335 Com efeito, compartilhamos de sua opinião quando atesta que "a contabilidade atual não se presta mais à apuração da base de cálculo do imposto de renda e da Contribuição Social sobre o Lucro já que se distanciou dos conceitos jurídicos de patrimônio, renda e lucro, necessários para a compreensão do fato

\footnotetext{
${ }^{333}$ NICACIO, Carlos N.. QUERQUILLI, Alexandre G. Mudanças nas regras contábeis, experiências internacionais e a relativa neutralidade do regime tributário de transição. In: FERNANDES, Edison Carlos. PEIXOTO, Marcelo Magalhães (coords.). Aspectos tributários da nova lei contábil: Lei 11.638/07. São Paulo: MP Ed., 2010. p. 43.

${ }^{334}$ Reitere-se que outros elementos são importantes para o exato reconhecimento do aspecto material do impostos de renda, os quais, por não serem relevantes para o prosseguimento do presente capítulo, não serão abordados aqui. Poderíamos citar, por exemplo, os direitos que comporiam o patrimônio se não fossem consumidos durante o período (renda consumida), as transferências de capital, os deveres ligados ao mero consumo, etc.

${ }^{335}$ MARTINS, Ricardo Lacaz. A Tributação da Renda Imobiliária. Tese. Doutorado. Universidade de São Paulo, 2009. p. 79.
} 
gerador dos mencionados tributos." 336 A base de cálculo estaria, assim, a infirmar o aspecto material do imposto de renda.

Parece comungar nessa mesma opinião João Francisco Bianco, ao destacar que: “(...) os acréscimos patrimoniais tributáveis pelo imposto de renda são aqueles apurados, conforme vimos acima, segundo a natureza jurídica dos negócios realizados, independentemente da sua aparência econômica." 337

Portanto, é de se perceber que o dimensionamento monetário do patrimônio trazido pela contabilidade, não raras vezes, não capta a essência e distorce as relações jurídicas que compõem o aspecto material do imposto de renda. E, dessa maneira, podemos concluir que, em diversas situações, a contabilidade infirma o aspecto material do IRPJ.

Cremos que tal noção restará melhor compreendida com a apresentação de algumas técnicas contábeis para o reconhecimento e mensuração de situações específicas, o que faremos linhas adiante (item 6.3).

\subsubsection{PRINCÍPIO DA REALIZAÇÃO DA RENDA E VALOR JUSTO (RECONHECIMENTO E MENSURAÇÃO CONTÁBIL)}

Dissemos acima que o reconhecimento de um recurso como ativo depende do controle sobre seus benefícios futuros. Não podemos, ao discorrer sobre o reconhecimento de receitas pela contabilidade, esquecer deste importante norte, uma vez que “(...) o reconhecimento da receita ocorre simultaneamente com o reconhecimento do aumento nos $\operatorname{ativos}(\ldots) ., 338$

Note-se que, na perspectiva contábil, não é necessário que o ativo (e, por vezes, a receita correlata) represente um direito objetivo, assim entendido aquele dentro do contexto de uma relação jurídica. A receita é reconhecida quando for provável que benefícios econômicos futuros fluam para a entidade e esses benefícios possam ser confiavelmente mensurados ${ }^{339}$.

\footnotetext{
${ }^{336}$ MARTINS, Ricardo Lacaz. A Tributação da Renda Imobiliária. Tese. Doutorado. Universidade de São Paulo, 2009. p. 95.

${ }^{337}$ BIANCO, João Francisco. Aparência Econômica e Natureza Jurídica. In: MOSQUERA, Roberto Quiroga. LOPES, Alexsandro Broedel (coords.). Controvérsias Jurídico-Contábeis (aproximações e distanciamentos). São Paulo, Dialética, 2010. p. 184.

${ }^{338}$ Item 4.47 do CPC Básico.

${ }^{339}$ Cf. CPC 30 (parágrafo sobre "objetivo").
} 
Por conta disso, meras expectativas de direitos objetivos podem, a depender das circunstâncias, ser reconhecidas pela contabilidade como ativos (e receitas) para bem atender seus propósitos; em determinados casos, não se exige uma efetiva transação com terceiros, bastando apenas a mera flutuação de valor de mercado. Não nos deixa mentir o CPC Básico, o qual justifica esse procedimento como instrumento de informação ao usuário da contabilidade:

“4.31. Ganhos incluem, por exemplo, aqueles que resultam da venda de ativos não circulantes. A definição de receita também inclui ganhos não realizados. Por exemplo, os que resultam da reavaliação de títulos e valores mobiliários negociáveis e os que resultam de aumentos no valor contábil de ativos de longo prazo. Quando esses ganhos são reconhecidos na demonstração do resultado, eles são usualmente apresentados separadamente, porque sua divulgação é útil para fins de tomada de decisões econômicas. Os ganhos são, em regra, reportados líquidos das respectivas despesas.” (destaques nossos)

Em suma, é esse o critério para o reconhecimento contábil da receita: probabilidade de geração de caixa futuro, independentemente de realização (efetiva transação com terceiros).

Destarte, à guisa de exemplo, no mercado de extração de determinados minerais, o controle do recurso (e o reconhecimento do ativo - estoque - e da sua respectiva receita - operacional) pode ser identificado como o momento da efetiva extração - e não na transação do mineral no mercado. Nesse sentido, Eliseu Martins nos ensina:

"Reconhecimento do lucro no momento da venda é o modelo que melhor mede o desempenho da entidade? (...) O que realmente completa, do ponto de vista da relevância, o conjunto vital de atividades da empresa no processo de ganhar dinheiro nessa indústria (indústria de mineração de ouro): produzir ou comercializar? (...) Assim, começa-se a reconhecer o lucro da extração do ouro no momento de sua produção, quando purificado, lingotado e guardado "safely". De que forma? Reconhecendo-se o estoque de ouro pronto, acabado, pelo valor de mercado, e considerando esse valor como receita (no lugar da venda), e contrapondo-se a essa receita todo o custo de obtê-lo, até então 
ativado como produto em elaboração. Reconhece-se, então, um lucro pela “produção", e não pela venda!".340

Isso acontece porque, nesse mercado, o maior esforço para obtenção da receita equivale ao trabalho de extração - e não a venda no mercado ${ }^{341}$.

Ganha força, então, aquilo que se convencionou chamar de valor justo, isto é, o valor pelo qual um ativo pode ser negociado, ou um passivo liquidado, entre partes interessadas, conhecedoras do negócio e independentes entre si, com a ausência de fatores que pressionem para a liquidação da transação ou que caracterizem uma transação compulsória $^{342}$.

Embora isso seja de bom uso para os usuários da contabilidade, não significa dizer, numa perspectiva de Direito Tributário, que há manifestação de capacidade contributiva no ato de a contabilidade reconhecer dado recurso com receita antes da efetiva transação no mercado. Nesse sentido, remetemos o leitor ao item 3.2.5, acima, na qual abordamos a questão da valorização mercadológica do ativo como insuficiente para exteriorizar manifestação de capacidade do cidadão para contribuir com as despesas gerais do Estado.

Por conta disso, quer-nos parecer que, nesse ponto, há um distanciamento entre a contabilidade e o Direito Tributário, devendo o lucro, para efeitos fiscais, ser ajustado para bem se alinhar com o Princípio da Capacidade Contributiva. Nesse sentido, o reconhecimento contábil de ativos e de receitas sem nenhum ajuste fiscal informaria o aspecto material do IRPJ.

\subsection{CASUÍSTICA}

\subsubsection{AJUSTE A VALOR PRESENTE}

O AVP foi incorporado à LSA por meio da inclusão do inciso VIII ao artigo 183 levada a efeito pela Lei $n^{\circ} 11.638 / 07$ e vazada nos seguintes termos: "os elementos do ativo decorrentes de operações de longo prazo serão ajustados a valor presente, sendo os

\footnotetext{
340 MARTINS, Eliseu. Ensaio sobre a Evolução do Uso e das Características do Valor Justo. In: MOSQUERA, Roberto Quiroga. LOPES, Alexsandro Broedel (coords.). Controvérsias Jurídico-Contábeis (aproximações e distanciamentos). São Paulo, Dialética, 2010. P. 140/141.

${ }^{341} \mathrm{O}$ item 6 (h) do CPC 30 exclui as receitas com extração de recursos minerais de seu campo de abrangência, significando que nesse tipo de operação a receita não é registrada quando da venda da produção. ${ }^{342} \mathrm{Cf}$. anexo ao CPC 15.
} 
demais ajustados quando houver efeito relevante." Essa mesma determinação é aplicável aos elementos do passivo, conforme mandamento do artigo 184, III, da LSA, com redação dada pela Lei $\mathrm{n}^{\circ}$ 11.941/09: "as obrigações, os encargos e os riscos classificados no passivo não circulante serão ajustados ao seu valor presente, sendo os demais ajustados quando houver efeito relevante."

Por meio dessa técnica contábil, e na dicção do item 9 do CPC 12, que disciplina o assunto, os ativos e passivos monetários "com juros implícitos ou explícitos embutidos" devem ser mensurados pelo seu valor presente quando do seu reconhecimento inicial.

Significa isso que, nas operações a prazo, os ativos (v.g., estoques, contas a receber) e os passivos (v.g., contas a pagar) não serão reconhecidos inicialmente pelo valor efetivamente praticado entre as partes e constantes dos documentos jurídicos que suportam a operação. Será descontado um montante equivalente à inflação e juros reais esperada no período entre a efetivação da operação e o prazo de pagamento. Para que a idéia fique mais clara, bem como a estreita ligação do AVP com a atual perspectiva da contabilidade (information approach), remetemos o leitor ao item 5.1.2 acima.

Note-se que, com a técnica do AVP, a contabilidade acaba por reconhecer não somente custos, despesas e receitas operacionais, mas passa a reconhecer também despesas e receitas financeiras. Como se disse no transcorrer de nosso trabalho, tal não pode ser censurado, pois o AVP se encontra em harmonia com a atual perspectiva da contabilidade, em sua função de bem atender seus usuários, ainda que, do ponto de vista jurídico, não se possa, aprioristicamente, dizer que há mais de um negócio jurídico praticado (ou seja, uma operação mercantil, por exemplo, e outra de financiamento).

Queremos significar que, juridicamente, há apenas um negócio jurídico (v.g., uma compra e venda de mercadorias a prazo), ainda que, contabilmente, parte dessa única operação seja retratada como se fosse um empréstimo. Graficamente, as múltiplas visões poderiam ser assim representadas:

\begin{tabular}{|l|l|}
\hline Jurídico: & $\frac{\text { Contábil: }}{\text { - Compra e venda (com contraprestação }}$ \\
pecuniária a prazo) & - Compra e venda; \\
\hline
\end{tabular}

Há, portanto, um manifesto conflito entre a visão jurídica e a contábil, de modo que, a despeito dos benefícios do AVP aos usuários da contabilidade, há uma distorção da 
realidade jurídica. Via de consequência, parece-nos que, nesse ponto, o instrumental contábil para determinação da base de cálculo do IRPJ infirma o aspecto material pressuposto constitucionalmente. Por isso, é de se aplaudir a neutralidade fiscal trazida no bojo do RTT, eis que, sob sua vigência, o AVP representa ajustes negativos e positivos.

De todo modo, seguindo em frente, valendo-nos do exemplo numérico fornecido no item 5.1.2.1. acima, constatamos que, no momento 1 , o lucro contábil é de \$224 (maior do que se considerada a operação ao seu cabo, i.e., no momento 2), uma vez que, nesse momento 1, a contabilidade deixou de reconhecer, no resultado do exercício, parte do custo de aquisição das mercadorias revendidas (será reconhecida apenas pro rata temporis). Com efeito, se a contabilidade for utilizada como instrumental definitivo para mensuração da base de cálculo do IRPJ (i.e., sem nenhuma correção), a base de cálculo seria composta por valor superior à capacidade contributiva, posto que a riqueza patrimonial auferida deve levar em conta todo o valor dos custos para revenda da mercadoria (o que não ocorre no momento 1 do exemplo numérico fornecido no item 5.1.2.1. citado acima).

Por fim, não podemos conceber que toda e qualquer compra e venda a prazo seja uma produção jurídica artificial, com o intento de dissimular duas operações: uma compra e venda à vista e um contrato de empréstimo. $\mathrm{O}$ fato de o comerciante considerar efeitos temporais (inflação e juros) na mensuração do preço de suas mercadorias não tem o condão de, por si só, desqualificar a operação como se fosse uma simulação de duas operações distintas. Assim, a essência econômica da operação não poderia servir de fundamento para afirmar a capacidade para contribuir com as despesas gerais do Estado por meio da imposição de imposto de renda.

\subsubsection{ARRENDAMENTO MERCANTIL (LEASING)}

O arrendamento mercantil, na dicção da Lei $n^{\circ}$ 6.099/74, é um negócio jurídico realizado entre pessoa jurídica, na qualidade de arrendadora, e pessoa física ou jurídica, na qualidade de arrendatária, e que tem por objeto o arrendamento de bens adquiridos pela arrendadora, segundo especificações da arrendatária e para uso próprio desta (artigo $1^{\circ}$, parágrafo único). Característica marcante do arrendamento mercantil é a opção de compra do bem ou renovação de contrato, como faculdade da arrendatária (artigo 5o, "c"). 
Tais características incentivaram Arnoldo Wald a conceituar o arrendamento mercantil da seguinte maneira: "Contrato misto, pela qual um financiador (pessoa jurídica) adquire e aluga a outra pessoa (física ou jurídica) um bem ou bens, móveis ou imóveis, para uso próprio desta, a prazo longo e médio, facultando ao locatário a aquisição do bem ou bens pelo preço residual." ${ }^{343}$

Todas as operações de arrendamento mercantil subordinam-se ao controle e fiscalização do BACEN, segundo normas estabelecidas pelo Conselho Monetário Nacional (artigo $7^{\circ}$ ). Valendo-se disso, a Resolução 2.309/96 regulamentou o arrendamento mercantil, estabelecendo duas espécies, a saber: o arrendamento mercantil financeiro e o operacional.

Ao disciplinar a primeira espécie, as autoridades monetárias concederam ao arrendamento mercantil condições de servir como uma verdadeira alternativa ao tradicional contrato de financiamento. Isso porque: (i) a soma das contraprestações pelo arrendamento do bem devem fazer com que a arrendadora recupere o custo de aquisição e obtenha retorno de seu investimento; (ii) as despesas de manutenção, assistência técnica e serviços correlatos à operacionalidade do bem arrendado devem ser de responsabilidade da arrendatária; e (iii) o preço para o exercício da opção de compra é livremente pactuado $\left(\operatorname{artigo} 5^{\circ}\right)$.

A despeito de ter notas típicas comuns do contrato de financiamento e do próprio contrato de aluguel, o arrendamento mercantil financeiro com eles não deve ser confundido $^{344}$. Trata-se, como bem aponta Arnoldo Wald, de “(...) negócio jurídico complexo, porque, associando diversos negócios, estes se formam por manifestações unitárias de vontade, não se decompondo em outros contratos."

De todo modo, podemos afirmar que, assim como o contrato de aluguel, a remuneração devida ao proprietário do bem (arrendadora) é uma contraprestação pelo uso. O arrendatário, para fruir do bem, sacrifica definitivamente ativos de seu patrimônio (caixa, depósitos de caixa em instituição financeira, etc.). Daí porque a Lei no 6.099/74 permitir ao arrendatário pessoa jurídica reputar, para efeitos fiscais, como custo ou despesa operacional as contraprestações pagas ou creditadas por força do contrato de arrendamento mercantil (artigo 11).

\footnotetext{
${ }^{343}$ WALD, Arnoldo. Direito das Obrigações. Teoria Geral das Obrigações e Contratos Civis e Comerciais. 15. ed. São Paulo: Malheiros, 2001. p. 555.

${ }^{344}$ Sobre as diferentes características, vide WALD, Arnoldo. Direito das Obrigações. Teoria Geral das Obrigações e Contratos Civis e Comerciais. 15. ed. São Paulo: Malheiros, 2001. p. 561.

${ }^{345}$ WALD, Arnoldo. Direito das Obrigações. Teoria Geral das Obrigações e Contratos Civis e Comerciais. 15. ed. São Paulo: Malheiros, 2001. p. 560.
} 
Com efeito, parece-nos que o mandamento inserto no artigo 11 nada mais é do que didático. A dedutibilidade para efeitos de apuração do IRPJ decorre da própria natureza jurídica do contrato, eis que a contraprestação devida pelo arrendatário representa um sacrifício de seu ativo pelo uso do bem. Não poderia a lei tributária, ao determinar a base de cálculo do IRPJ, dispor de forma diversa, sob pena de infirmar o aspecto material do imposto de renda.

Se assim é, nada mais coerente do que reafirmar que o Brasil não poderia adotar o modelo de dependência total. Isso porque, como dissemos antes, o reconhecimento de um ativo contábil exige que a entidade tenha o controle dos benefícios futuros dos recursos, independentemente do título de propriedade. A própria LSA, ao discorrer sobre o ativo imobilizado, determina que lá sejam incluídos os bens decorrentes de operações que transfiram à companhia os benefícios, riscos e controle (artigo 179, IV).

Seguindo esse norte, o CPC 06, que disciplina o registro contábil das operações de arrendamento mercantil, orienta o registro do bem objeto do contrato como ativo da arrendatária. Isso significa que a contraprestação paga não transitará no resultado do exercício, mas tão somente o montante a título de depreciação do bem e "despesas financeiras".

Deve-se salientar - mais uma vez - que não estamos a censurar a forma do registro contábil, posto que coerente com a atual perspectiva da contabilidade. $\mathrm{O}$ registro do bem no ativo, do ponto de vista informacional do usuário da contabilidade, é de extremo benefício, posto que melhor prevê o fluxo de caixa futuro da entidade, já que se espera o exercício futuro da opção de compra do bem.

Todavia, o óbice à dedutibilidade da contraprestação pelo arrendamento mercantil (sacrifício definitivo do ativo pelo uso do bem) infirma o aspecto material do imposto de renda, tendo em vista tratar-se de verdadeiro consumo (decréscimo) do patrimônio da entidade pelo direito de uso do bem ${ }^{346}$.

Por conta disso, ousamos discordar da opinião exarada pela Superintendência Regional da Receita Federal da $8^{a}$. Região Fiscal por meio da Processo de Consulta $n^{\circ}$ 7/12 (abaixo transcrita), que não autorizou a dedutibilidade das contraprestações de leasing no caso de um contribuinte não optante pelo RTT :

\footnotetext{
${ }^{346}$ Ressalte-se que nosso pensamento não colide com a ressalva prevista na Lei no 9.249: “Art. 13. Para efeito de apuração do lucro real e da base de cálculo da contribuição social sobre o lucro líquido, são vedadas as seguintes deduções, independentemente do disposto no art. 47 da Lei $\mathrm{n}^{\circ}$ 4.506, de 30 de novembro de 1964: (...) II - das contraprestações de arrendamento mercantil e do aluguel de bens móveis ou imóveis, exceto quando relacionados intrinsecamente com a produção ou comercialização dos bens e serviços; (...).”
} 
“Órgão: Superintendência Regional da Receita Federal - SRRF / 8a. Região Fiscal

Assunto: Imposto sobre a Renda de Pessoa Jurídica - IRPJ.

Ementa: ARRENDAMENTO MERCANTIL FINANCEIRO. MUDANÇAS NO CRITÉRIO DE CONTABILIZAÇÃO. EFEITOS FISCAIS.

Os lançamentos na contabilidade da arrendatária referentes aos contratos de arrendamento mercantil devem estar em conformidade com a nova regra do inciso IV do art. 179 da Lei ${ }^{\circ}$ 6.404, de 1976, alterado pela Lei $\mathrm{n}^{\circ} 11.638$, de 2007. Contudo, tais mudanças no critério de escrituração contábil não afetarão a base de cálculo do IRPJ apurada pela pessoa jurídica optante pelo Regime Tributário de Transição (RTT).

Ou seja, por força das disposições introduzidas pela Lei $\mathrm{n}^{\mathbf{0}} 11.638$, de 28/12/2007, e pelos arts. 37 e 38 da Lei $n^{\circ} 11.941$, de 2009, as alterações que modifiquem o critério de reconhecimento de receitas, custos e despesas computadas na escrituração contábil, para apuração do lucro líquido do exercício conforme definido no art. 191 da Lei $n^{\circ}$ 6.404, de 15/12/1976, não terão efeitos para fins de apuração do lucro real da pessoa jurídica optante pelo RTT, prevalecendo para fins tributários os métodos e critérios contábeis vigentes em 31/12/2007. Ou seja, os ajustes decorrentes do critério anterior, e do atual devem ser implementados de forma extracontábil na empresa optante pelo RTT em 2008 e 2009, objetivando buscar a neutralidade fiscal. Lembramos que a partir de 2010, a adoção do RTT é obrigatório para as Pessoas Jurídicas que apurem o resultado com base no lucro real. $\underline{\text { Na hipótese de a consulente não ter optado pelo RTT, nos anos de } 2008 \text { e } 2009,}$ a contabilização dos contratos de arrendamento mercantil na arrendatária também segue a determinação do inciso IV do art. 179 da Lei $\mathrm{n}^{\circ} 6.404$, de 1976, alterado pela Lei $\mathrm{n}^{\circ} 11.638$, de 2007 , sendo vedada a realização de ajustes extracontábeis.

Dispositivos Legais: Lei $\mathrm{n}^{\circ}$ 6.404, de 1976, art. 179, inciso IV, alterado pela Lei $n^{\circ} 11.638$, de 2007; MP no 449, de 2008, arts. 15 a 18, convertida na Lei $n^{\circ}$ 11.941, de 2009 .

(...)

EDUARDO NEWMAN DE MATTERA GOMES - Chefe" (destaques nossos) 
Nem se alegue que a opção de aquisição do título de propriedade do bem ao final do contrato justificaria dizer que o sacrifício do ativo (caixa, v.g.) não seria definitivo e, portanto, conferiria caráter de indedutibilidade às contraprestações do arrendamento mercantil. Trata-se de mera faculdade que pode ou não ser exercida, estando condicionada não apenas à livre intenção da arrendatária, mas ao cumprimento de suas obrigações assumidas contratualmente (como o pagamento das contraprestações). Vê-se, assim, que a aquisição do título de propriedade não é mais do que mera expectativa de direito, condicionada a uma série de circunstâncias fáticas.

\subsubsection{LUCROS DE COLIGADAS E CONTROLADAS}

Dispõe a LSA (artigo 248) que os investimentos em coligadas ou em controladas e em outras sociedades que façam parte de um mesmo grupo ou estejam sob controle comum serão avaliados pelo MEP. Em linhas gerais, por esse método, um investimento em coligada e em controlada (neste caso, no balanço individual) é inicialmente reconhecido pelo custo e o seu valor contábil será aumentado ou diminuído pelo reconhecimento da participação do investidor nos lucros ou prejuízos do período, gerados pela investida após a aquisição ${ }^{347}$.

E assim se faz em nome de uma melhor eficiência das demonstrações contábeis, servindo como instrumento ao usuário da contabilidade para avaliar a situação econômica da entidade. Nesse aspecto, Iudícibus e et. al. afirmam: “(...) o método de equivalência patrimonial acompanha o fato econômico, que é a geração dos resultados e não a formalidade da distribuição de tal resultado." 348

A despeito da eficiência da aplicação do MEP para fins informacionaiscontábeis, a mera apuração de lucro por coligadas ou controladas não representa manifestação de capacidade contributiva para a investidora.

Nesse sentido, dois aspectos merecem destaque.

Primeiro, o lucro contábil apurado pela investida - como se está a demonstrar neste trabalho - não necessariamente confirma o aspecto material do IRPJ. Assim, ainda que se admitisse a tributação na investidora dos lucros da investida, tais lucros mereceriam ser ajustados para plena compatibilização com o Princípio da Capacidade Contributiva.

\footnotetext{
${ }^{347}$ Cf. item 11 do CPC 18.

348 IUDÍCIUS, Sérgio de; GELBCKE, Ernesto Rubens; MARTINS, Eliseu. Manual de Contabilidade Societária. São Paulo: Atlas, 2010. P. 170.
} 
Segundo, os lucros apurados pela investida, enquanto tal - e não como dividendos distribuídos-, não representam direito adquirido da investidora. Do ponto de vista jurídico, não há liame que una os lucros da investida e a investidora antes, por exemplo, da efetiva deliberação societária que conclua pela distribuição de resultados ${ }^{349}$. Apenas com tal deliberação é que surge capacidade para a investidora de contribuir com as despesas gerais do Estado, eis que, inevitavelmente, é neste momento que nasce o direito à percepção dos frutos do investimento. Antes disso, há apenas mera expectativa de direito, podendo não vir a se confirmar. Não pode a investidora requerer perante nenhuma autoridade judicial quaisquer frutos, antes do procedimento desenhado pela legislação societária.

E a deliberação societária que define a destinação dos lucros não pode ser qualificada como mera formalidade jurídica. Note-se que, se os investidores decidirem não descapitalizar a empresa, pode ocorrer de tais lucros serem absorvidos por futuros prejuízos, não restando à investidora nenhum fruto da aplicação de seu capital, o que revelaria absoluta falta de capacidade contributiva ante a impossibilidade de distribuição de dividendos. Nessa situação, fica evidente que a tributação sobre os lucros apurados pela investida representa mera expectativa de aumento de patrimônio.

Por conta dessa circunstância é que o artigo 74 da Medida Provisória nº 2.15835/01 - que disciplina a tributação dos lucros auferidos no exterior por coligadas e controladas - vem sendo objeto de discussão no STF em Ação Direta de Inconstitucionalidade intentada pela Confederação Nacional da Indústria (ADIN 2.588, julgamento ainda pendente ${ }^{350}$ ). Por meio desse dispositivo, os lucros auferidos por controlada ou coligada no exterior serão considerados disponibilizados para a controladora ou coligada no Brasil na data do balanço no qual tiverem sido apurados, na forma do regulamento. Noutros termos, os lucros de coligadas ou controladas no exterior seriam tributados no Brasil independentemente de efetiva realização.

Até o momento, quatro ministros - Marco Aurélio, Sepúlveda Pertence (aposentado), Ricardo Lewandowski e Celso de Mello - votaram pela procedência da ADIN e outros quatro - Nelson Jobim (aposentado), Eros Grau (aposentado), Ayres Britto e Cezar Peluso - posicionaram-se pela improcedência da ação.

\footnotetext{
${ }^{349}$ Salvo se o contrato social dispuser que a distribuição é automática.

${ }^{350}$ Conforme informação obtida por meio do website do STF, em 17/08/2011 o julgamento foi suspenso para colher o voto do Ministro Joaquim Barbosa, à época licenciado. Acesso em 20/11/2012 http://www.stf.jus.br/portal/processo/verProcessoAndamento.asp?incidente=1990416.
} 
A relatora do processo, ministra Ellen Gracie (aposentada), manifestou-se pela procedência parcial, declarando a inconstitucionalidade da expressão "ou coligadas", contida no caput do artigo 74 da indigitada Medida Provisória. Em seu sentir, haveria que se fazer distinção entre empresas controladas e empresas coligadas (já que nestas não há posição de controle da empresa situada no Brasil sobre a sua coligada localizada no exterior) e, via de consequência, não se poderia falar em disponibilidade jurídica, pela coligada brasileira, dos lucros auferidos pela coligada estrangeira antes da efetiva remessa desses lucros, ou, pelo menos, antes da deliberação dos órgãos diretores sobre a destinação dos lucros do exercício.

De toda sorte, parece-nos que a (por enquanto) isolada voz da Ministra Relatora não merece acolhida. A circunstância de o investidor deter o controle acionário da investida - e eventualmente não depender de vontades alheias para a efetivação da distribuição de dividendos - não evita que a mera apuração de lucro não se materialize em dividendos e, via de consequência, não reste demonstrada capacidade contributiva. Relembre-se que, mesmo nessa circunstância, o lucro poderia ser absorvido por prejuízos futuros, sem que se releve capacidade para contribuição com as despesas gerais do estado. Seu patrimônio, antes de deliberação societária sobre a destinação dos lucros, não pode ser considerado acrescido.

O entendimento a ser prevalecente, segundo esperamos como medida de incorrigível justiça e hermenêutica constitucional, deve ser aquele exposto pelo ministro Celso de Mello, de cuja minuta de voto na mencionada ADIN se pode extrair a seguinte lição:

"Resulta claro que as empresas controladas ou coligadas no exterior são pessoas jurídicas que possuem personalidade jurídica autônoma, própria, distinta daquela assumida pelas empresas controladoras ou por suas coligadas domiciliadas no Brasil, que estão a elas vinculadas juridicamente, no que se refere à distribuição dos lucros, ao que dispõe, de um lado, os seus estatutos sociais, e de outro o próprio ordenamento positivo do local do lugar onde tem o seu próprio domicílio. Por esse motivo, os resultados apurados no exercício nem sempre se encontrarão à disposição dos acionistas na data de elaboração do balanço anual."

A tributação dos lucros no exterior, antes da efetiva distribuição de dividendos, somente poderia ser admitida ao amparo de presunções absolutas, cuja aplicação em matéria tributária merece severas restrições, sob pena de ruir o rígido Sistema Tributário 
Nacional. Por conta disso, é que, data venia, não admitimos a conclusão do ministro Ayres Brito, que julgou improcedente a ADIN, fundado numa demasiada tolerância da aplicação do artigo $150, \S 7^{\circ}$, da $\mathrm{CF} / 88$. Em sua minuta de voto na referida ADIN, o ministro assim se manifestou:

"O lucro obtido pelas controladas e coligadas no exterior repercutem positivamente na empresa brasileira. Isso porque essa empresa brasileira se torna titular desses lucros, na medida de sua participação no capital social das controladas ou coligadas. Sem desconhecimento de que tais lucros venham a ser objeto de reinvestimento, reserva de capital, aplicação em ativos, etc., a significar sua não distribuição como dividendos às empresas brasileiras, conforme o caso. Mas isso não impede a respectiva tributação pela via legal da presunção de ingresso ou antecipação do fato gerador, conforme $\S 7^{\circ}$ do artigo 150 da CF."

Mais uma vez manifestamos nossa discordância em relação à conclusão do ministro Ayres Brito, uma vez que, primeiro, não há que se falar em "se tornar titular" dos lucros auferidos no exterior. O "se tornar titular" exige, inequivocadamente, do instrumento jurídico que ligue os lucros auferidos e o investidor, o que, via de regra, acontecerá por meio de deliberação societária sobre a distribuição de dividendos. Ademais, como já acentuado antes, o ministro, data venia, abriu um perigoso precedente quanto à aplicação do $\S 7^{\circ}$ do artigo 150 da $\mathrm{CF} / 88$, de modo que, se prevalecente, facultará aos entes tributantes uma ampla gama de possibilidades e alternativas para exigir tributos alheios à ocorrência do fato gerador desenhado de maneira rígida pelo constituinte originário. Ainda que prevalecente esse entendimento, não se poderia negar o direito expressado pela parte final do indigitado dispositivo constitucional, no sentido de que "(...) imediata e preferencial restituição da quantia paga, caso não se realize o fato gerador presumido".

De todo modo, é de se salientar que o mesmo STF já se manifestou no sentido de que não há que se falar em tributação pelo imposto de renda antes da distribuição (realização) de lucros apurados pelas sociedades.

Trata-se do RE 172.058-1/SC no famoso caso do ILL - imposto sobre o lucro líquido, cuja lei (Lei no 7.713) previa em seu artigo 35 uma tributação dos dividendos auferidos pelo acionista, ainda que não distribuídos. Naquela ocasião, o STF decidiu que o imposto somente poderia ser exigido das empresas individuais ou das sociedades limitadas em que a distribuição de dividendos, por força de deliberação em contrato social, fosse automática, vale dizer, no momento de sua apuração. Nos demais casos em que a 
distribuição dependeria de deliberação específica, a Corte Maior decidiu ser inconstitucional a exigência contida na indigitada lei.

Da ementa da decisão se extraem as seguintes conclusões:

“(...) TRIBUTO - RELAÇÃO JURÍDICA ESTADO/CONTRIBUINTE PEDRA DE TOQUE. No embate diário Estado/contribuinte, a Carta Política da República exsurge com insuplantável valia, no que, em prol do segundo, impõe parâmetros a serem respeitados pelo primeiro. Dentre as garantias constitucionais explícitas, e a constatação não exclui o reconhecimento de outras decorrentes do próprio sistema adotado, exsurge a de que somente à lei complementar cabe "a definição de tributos e de suas espécies, bem como, em relação aos impostos discriminados nesta Constituição, a dos respectivos fatos geradores, bases de cálculo e contribuintes" - alinea "a" do inciso III do artigo 146 do Diploma Maior de 1988. IMPOSTO DE RENDA - RETENÇÃO NA FONTE - SÓCIO COTISTA. A norma insculpida no artigo 35 da Lei $n^{\circ}$ 7.713/88 mostra-se harmônica com a Constituição Federal quando o contrato social prevê a disponibilidade econômica ou jurídica imediata, pelos sócios, do lucro líquido apurado, na data do encerramento do período-base. Nesse caso, o citado artigo exsurge como explicitação do fato gerador estabelecido no artigo 43 do Código Tributário Nacional, não cabendo dizer da disciplina, de tal elemento do tributo, via legislação ordinária. Interpretação da norma conforme o Texto Maior. IMPOSTO DE RENDA - RETENÇÃO NA FONTE ACIONISTA. O artigo 35 da Lei $n^{\circ} 7.713 / 88$ e inconstitucional, ao revelar como fato gerador do imposto de renda na modalidade "desconto na fonte", relativamente aos acionistas, a simples apuração, pela sociedade e na data do encerramento do período-base, do lucro líquido, já que o fenômeno não implica qualquer das espécies de disponibilidade versadas no artigo 43 do Código Tributário Nacional, isto diante da Lei $n^{\circ}$ 6.404/76. IMPOSTO DE RENDA RETENÇÃO NA FONTE - TITULAR DE EMPRESA INDIVIDUAL. O artigo 35 da Lei $n^{\circ} 7.713 / 88$ encerra explicitação do fato gerador, alusivo ao imposto de renda, fixado no artigo 43 do Código Tributário Nacional, mostrando-se harmônico, no particular, com a Constituição Federal. Apurado o lucro líquido da empresa, a destinação fica ao sabor de manifestação de vontade única, ou seja, do titular, fato a demonstrar a disponibilidade jurídica. 
Situação fática a conduzir a pertinência do princípio da despersonalização. $(\ldots) "$

O Ministro Relator, Marco Aurélio Melo, após associar o conteúdo de disponibilidade jurídica e econômica de renda ao direito de dispor, isto é, poder de consumir a coisa, de aliená-la, de gravá-la de ônus e de submetê-la a outrem, argumentou ser imprescindível concluir que a disponibilidade de renda, no caso em análise, não poderia ser considerada a data da mera apuração do lucro, sendo necessária a deliberação societária para distribuição de dividendos.

Denota-se, portanto, mais uma incompatibilidade entre o lucro contábil - que viabiliza o reconhecimento automático de lucros de controladas e coligadas via MEP - e o aspecto material do IRPJ, razão pela qual não se pode admitir a adoção do modelo de dependência total.

\subsubsection{ATIVOS BIOLÓGICOS}

O CPC 29 dispõe sobre a forma de contabilização dos chamados ativos biológicos e produtos agrícolas. Por definição lá encontrada, ativo biológico é um animal e/ou uma planta, vivos ${ }^{351}$.

Contabilmente, o ativo biológico deve ser mensurado ao valor justo subtraída da despesa de venda no momento do reconhecimento inicial e no final de cada período de competência. Significa dizer que a mensuração dos estoques (e consequente reflexo no resultado do exercício ${ }^{352}$ ) acontecerá independentemente de transação com terceiros. Isso com base no chamado valor justo, isto é, o valor pelo qual um ativo pode ser negociado, ou um passivo liquidado, entre partes interessadas, conhecedoras do negócio e independentes entre si e com a ausência de fatores que pressionem para a liquidação da transação ou que caracterizem uma transação compulsória.

Em suma, o resultado da entidade sujeita a esse pronunciamento contábil poderá ser acrescido antes mesmo da negociação com terceiros.

Todavia, não nos parece que isso seja suficiente para aferir a capacidade contributiva das entidades sujeitas a esse pronunciamento contábil. Isso porque a avaliação dos estoques a valor justo, embora significativa para fins contábeis, na medida em que

\footnotetext{
${ }^{351}$ Cf. item 4 do CPC 29.

${ }^{352}$ Cf. item 26 do CPC 29: "O ganho ou a perda proveniente da mudança no valor justo menos a despesa de venda de ativo biológico reconhecido no momento inicial até o final de cada período deve ser incluído no resultado do exercício em que tiver origem."
} 
expõe aos usuários as expectativas de geração de caixa futuro, não representa um novo direito ingressado no patrimônio (jurídico) da entidade. Trata-se de mera expectativa baseada numa projeção de transação com terceiros independentes, sem que isso represente nenhuma mutação no patrimônio da entidade, por mais líquido que seja o mercado.

A demonstração de capacidade de contribuir com as despesas gerais do estado ocorrerá, no mais das vezes, quando da transação dos produtos com terceiros, ocasião na qual se consubstanciará um novo direito ao patrimônio da entidade, revelado pela contraprestação ao produto biológico alienado.

Tem o mesmo sentir Natanael Martins, que conclui:

“(...) esse novo regramento contábil dado aos ativos biológicos e aos produtos deles resultantes demonstra que a nova contabilidade quer que o balanço reflita "o patrimônio econômico" da entidade empresarial, medido segundo valores justos existentes naquele dado momento de avaliação, ainda que a riqueza assim demonstrada, em termos de renda, não esteja efetivamente realizada." 353 Sobre a matéria, o RIR/99 dispõe que:

“Art. 297. Os estoques de produtos agrícolas, animais e extrativos poderão ser avaliados aos preços correntes de mercado, conforme as práticas usuais em cada tipo de atividade (Decreto-Lei $\mathrm{n}^{\circ} 1.598$, de 1977, art. 14, § $4^{\circ}$ ).”

Em vista do citado disciplinamento legal da matéria, as autoridades fiscais, quando do pronunciamento técnico emitido por ocasião do Parecer Normativo $n^{\circ}$ 57/76, trataram o nascimento e perecimento de crias na atividade agropecuária como superveniências e insubsistências ativas, recebendo o seguinte tratamento contábil e tributário:

“Creditada pelo nascimento do animal, pelo preço real de custo ou pelo preço corrente no mercado, a débito da conta do ativo a que se destina a cria nascida, transferindo-se o saldo para Lucros e Perdas, como receita tributável;"

Veja-se, portanto, que, no entender das autoridades fiscais, a entidade deveria registrar em seu resultado do exercício (lucros e perdas) as superveniências ativas decorrentes do nascimento do gado (tendo-se por contrapartida - débito - a conta do ativo que registra a cria), desprezando-se completamente a necessidade da efetiva transação com terceiros.

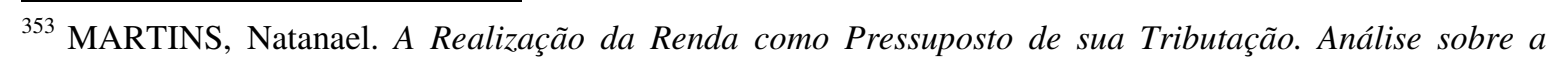
Perspectiva da Nova Contabilidade e do RTT. In: MOSQUERA, Roberto Quiroga. LOPES, Alexsandro Broedel (coords.). Controvérsias Jurídico-Contábeis (aproximações e distanciamentos). São Paulo, Dialética, 2010. p. 360. 
Décadas depois, por meio do Ato Declaratório Normativo COSIT n 32/94, a tributação pelo imposto de renda foi reafirmada, tendo em vista disposição segunda o qual a contrapartida do aumento do ativo, em decorrência da atualização do valor dos estoques de produtos agrícolas, animais e extravios destinados à venda, tanto em virtude do registro no estoque de crias nascidas no período-base, como pela avaliação do estoque a preço de mercado, constitui receita tributável pelo imposto de renda.

Somente em 2002, por meio da Instrução Normativa $n^{\circ} 257$, é que esse entendimento foi melhor desenhado, tendo o artigo 16 determinado que a contrapartida do aumento do ativo, em decorrência da atualização do valor dos estoques de produtos agrícolas, animais e extrativos destinados à venda, tanto em virtude do registro no estoque de crias nascidas no período de apuração, como pela avaliação do estoque a preço de mercado, constitui receita operacional, que comporá a base de cálculo do imposto sobre a renda no período de apuração em que ocorrer a venda dos respectivos estoques.

Dessa forma, tal receita operacional, no período de sua formação, constituirá exclusão do lucro líquido e deverá ser controlada na Parte B do Lalur, merecendo adição ao lucro líquido para efeitos de se apurar o Lucro Real apenas no período de apuração em que ocorrer a venda dos estoques atualizados.

Com efeito, parece-nos que as próprias autoridades fiscais reconheceram que a tributação do aumento do estoque agrícola pelo valor de mercado sem nenhuma efetiva transação com terceiros representaria uma inconveniente medida de sufocamento do contribuinte. Assim, evitou-se que um inicial esforço do contribuinte (vale dizer, a mera produção agrícola, pecuária e afins) seja tributado como se a cadeia comercial fosse inteiramente completada.

Por conta disso, não podemos emitir outra opinião senão aquela que advoga pelo não reflexo do CPC 29 (ativo biológicos) para efeitos tributários, devendo o legislador tributário, querendo manter harmonia com os elementares direitos preconizados pelo constituinte, promover ajustes ao lucro líquido do exercício para efeitos de apuração do Lucro Real. Essa casuística, aliada às premissas adotadas durante este trabalho, reafirmam o argumento de que, no Brasil, não se pode admitir o modelo de dependência total entre o balanço societário e tributário. 


\subsubsection{INSTRUMENTOS FINANCEIROS}

Em linhas gerais, instrumentos financeiros são representativos de contratos que dão origem a ativos e a passivos financeiros, assim entendidos aqueles que conferem direito, ou geram obrigação, de receber/pagar caixa ou outro ativo financeiro. Nesse aspecto é que se diferenciam dos ativos tangíveis e intangíveis, na medida em que “(...) o controle de tais ativos tangíveis e intangíveis cria a oportunidade de geração de caixa ou outro ativo financeiro, mas não dão direito ao recebimento direto de um ativo financeiro ou caixa." 354

Os instrumentos financeiros podem ser classificados em quatro categorias, as quais levam em conta a intenção da entidade ao adquiri-los ${ }^{355}$. Dentre elas, os instrumentos financeiros assumidos inequivocamente para negociação em curto prazo no mercado organizado (os chamados "instrumentos financeiros mensurados pelo valor justo por meio de resultado") são mensurados pelo valor justo em mercado ativo e sua variação reconhecida como receita/despesa financeira no resultado do exercício, independentemente de sua efetiva realização.

E assim se dá porque, consoante nos ensinam os Professores da FEA/FIPECAFI:

“(...) considera-se que o evento crítico para o reconhecimento da receita não é a venda dos respectivos instrumentos, mas sim a variação do seu valor justo. (...) É diferente, por exemplo, do caso de estoques em uma loja de roupas. Nesse caso a receita somente poderá ser reconhecida quando houver efetivamente a venda. Na negociação desses títulos que têm mercado ativo e líquido, o esforço não se concentra na venda, o que é diferente do que ocorre na loja de roupas.",356

Veja-se, portanto, que dado que tais instrumentos foram adquiridos para negociação em mercado organizado de liquidez imediata, a contabilidade confere a seus usuários a oportunidade de visualizar as expectativas de geração de fluxo de caixa futuro da entidade.

\footnotetext{
${ }^{354}$ Cf. item AG10 do CPC 39.

355 IUDÍCIUS, Sérgio de; GELBCKE, Ernesto Rubens; MARTINS, Eliseu. Manual de Contabilidade Societária. São Paulo: Atlas, 2010. p. 113.

${ }^{356}$ IUDÍCIUS, Sérgio de; GELBCKE, Ernesto Rubens; MARTINS, Eliseu. Manual de Contabilidade Societária. São Paulo: Atlas, 2010. p. 125.
} 
Todavia, como temos sublinhado ao longo deste trabalho, a flutuação de variação do mercado, antes de sua efetiva realização, não tem o condão de, por si só, viabilizar capacidade para contribuir com as despesas gerais do Estado.

$\mathrm{O}$ argumento de que o mercado no qual os instrumentos são mensurados é de excessiva liquidez, próximo ao próprio caixa, não é capaz, em nossa visão, de reverter essa situação. Isso porque, a despeito de sua imediata liquidez, o aumento de valor de mercado continua conferindo, ao detentor do instrumento financeiro, mera expectativa de ganho, a qual pode não vir a se concretizar. Não pressupõe uma transação efetiva e definitiva com terceiros, apta a demonstrar capacidade para contribuir com as despesas gerais do Estado. Não há aquisição de direitos subjetivos no bojo de uma relação jurídica, pressuposto de renda constitucionalmente tributada.

É nesse ponto, portanto, que, mais uma vez, chamamos a atenção para a dicotomia entre o reconhecimento contábil e a capacidade de contribuir com as despesas gerais do Estado.

Por fim, é de se sublinhar que a vigente legislação do IRPJ determina que os resultados positivos ou negativos incorridos nas operações realizadas em mercados de liquidação futura, inclusive os sujeitos a ajustes de posições, serão reconhecidos por ocasião da liquidação do contrato, cessão ou encerramento da posição (artigo 32 da Lei no. 11.051/04). Noutras palavras, o legislador autorizou os contribuintes a oferecerem à tributação tais operações apenas quando de sua efetiva realização, de maneira a se evitar que ganhos ou perdas potenciais (mas não realizados) não influam na base de cálculo do IRPJ.

Em nossa visão, se, por um lado, esse mandamento, para as operações nela abrangidas, é consentâneo com a capacidade contributiva, por outro lado, é de se advertir que tal regra não tem o condão de abranger todos os instrumentos financeiros (exemplo: as operações financeiras realizadas em mercados de balcão não organizados). Para essa última situação, vislumbramos um conflito entre a base de cálculo do IRPJ desenhada pelo legislador ordinário e aquela convergente com a Carta Magna. 


\subsubsection{RECONHECIMENTO DE ATIVO INTANGÍVEL NOS CONTRATOS DE CONCESSÃO}

Importante norte à contabilização dos chamados contratos de concessão foi trazido pela Interpretação CPC 01 (ICPC 01), particularmente na perspectiva da entidade privada (concessionária). Sob sua orientação estão as operações em que a concessionária não detém o controle da infraestrutura objeto da concessão, vale dizer, os contratos de concessão nos quais a concessionária apenas administra os ativos públicos em nome do poder concedente, ainda que exista certa margem de liberdade administrativa ${ }^{357}$.

Nessas situações, as concessionárias não devem reconhecer os investimentos realizados na implementação ou na melhoria da infraestrutura como se os imobilizados fossem seus, tal como ocorria sob os auspícios do padrão contábil vigente antes da Lei $\mathrm{n}^{\circ}$ 11.638/07. Devem, pelo contrário, registrar tais investimentos ou como ativo financeiro ou como ativo intangível ou, em certos casos, como ativo financeiro e intangível.

De maneira geral, pode-se dizer que o critério que diferencia o registro de um (ativo financeiro) ou de outro (ativo intangível) é a existência de garantia do recebimento pelos recursos investidos na infraestrutura. Quer isso significar que, se a receita da concessionária for garantida pelo poder público (como num contrato em que o concedente pagará à concessionária pela construção de um presídio), a ICPC 01 determina que seja registrado um ativo financeiro. Do contrário, caso o poder concedente garanta apenas o direito à exploração de uma atividade (como num contrato em que o concedente garante à concessionária o direito de arrecadar pedágio dos cidadãos), registra-se um ativo intangível $^{358}$.

Num caso ou no outro, o ativo é mensurado pelo seu valor justo (eis outra diferença entre o regime contábil atual e o anterior à reforma da LSA), ou seja, os respectivos valores justos das importâncias recebíveis pela concessionária. Para melhor ilustrar essa afirmação, vejamos o exemplo ilustrativo que acompanha o ICPC 01:

"EI14. O concessionário fornece serviços de construção ao concedente em troca de ativo intangível, ou seja, o direito de cobrar pedágios dos usuários da estrada nos anos 3-10. De acordo com o Pronunciamento Técnico CPC 04 Ativo Intangível, o concessionário deve reconhecer o ativo intangível pelo

${ }^{357}$ Cf. IUDÍCIUS, Sérgio de; GELBCKE, Ernesto Rubens; MARTINS, Eliseu. Manual de Contabilidade Societária. São Paulo: Atlas, 2010. p. 453.

${ }^{358} \mathrm{Cf}$. itens 16 e 17 do ICPC 01. 
custo, ou seja, o valor justo da contraprestação transferida para adquirir o ativo, que é o valor justo da contraprestação recebida ou a receber pelos serviços de construção entregues.

EI15. Durante a fase de construção do contrato, o ativo do concessionário (que representa seu direito acumulado a ser pago por fornecer serviços de construção) deve ser classificado como ativo intangível (licença para cobrar os usuários da infraestrutura). O concessionário estima que o valor justo de sua contraprestação recebida seja equivalente aos custos de construção previstos mais a margem de 5\%. Presume-se também que, de acordo com o Pronunciamento Técnico CPC 20 - Custos de Empréstimos, o concessionário capitalize os custos de empréstimo, estimados em 6,7\%, durante a fase de construção do contrato:

Tabela 2.2 - Mensuração inicial do ativo intangível

$\begin{array}{|lr|}\text { Serviços de construção no ano 1 }(\$ 500 x(1+5 \%)) & 525 \\ \text { Capitalização de custos financeiros }(\operatorname{tabela} 2.4) & 34 \\ \text { Serviços de construção no ano 2 }(\$ 500 x(1+5 \%)) & 525 \\ \text { Ativo intangível ao final do ano 2 } & 1.084 \text {, }\end{array}$

(destaques nossos)

Veja-se, portanto, que o ativo intangível será mensurado não só pelo custo dos investimentos como também por uma margem de lucro (no exemplo fornecido pelo ICPC 01, de 5\%). Via de consequência, a contabilidade, mesmo antes da aquisição do direito à percepção de receitas (no exemplo da concessão de rodovia pública, a cobrança de pedágio dos usuários das rodovias), apurará um lucro resultado de projeção de ganhos estimados pela administração da companhia.

Isso acontece porque a contrapartida do ativo intangível será o resultado do exercício, o que significa, utilizando-se o exemplo do ICPC 01, que o concessionário reconhecerá um acréscimo contábil equivalente a $5 \%$ do custo da construção.

Exemplo similar é fornecido por Sérgio de Iudícibus e et. al.:

“Assim, de maneira similar ao exemplo anterior, assume-se que a receita de construção será igual ao custo projetado mais 5\%. Nesse sentido, nos anos 1-4, a $\mathrm{ABC}$ reconhece, no resultado do exercício, custos de construção de $\$ 1.000$ 
milhões reais, receitas de construção de $\$ 1.050$ milhões (custo $+5 \%$ ), o que gera consequentemente um lucro bruto de $\$ 50$ milhões reais." 359

Embora o registro do ativo intangível pelo chamado valor justo tenha grandes utilidades para os usuários da contabilidade, é de se destacar que o lucro apurado a partir de meras projeções perpetradas pela administração da companhia não pode servir de índice para a tributação da renda. Isso porque o direito à receita nascerá tão somente da efetiva prestação de serviço ao usuário - e não do mero sacrifício de recursos para implementar ou para melhorar a infraestrutura objeto da concessão.

Noutros termos, o investimento não tem o condão de, por si só, garantir à companhia o direito que acresceria seu patrimônio. Sendo assim (e reiterando que a noção de renda constitucional está ligada ao aumento de direitos patrimoniais), o lucro contábil nessa situação infirmaria, em nosso sentir, o aspecto material constitucionalmente posto.

\subsubsection{VARIAÇÃO CAMBIAL}

Técnica disseminada há tempos pelos contadores é a atualização monetária de ativos ou passivos sujeitos à variação de moeda estrangeira nos casos de empréstimos, importações, exportações, dentre outras. Significa isso que, exemplificativamente, um dado crédito da entidade contabilizada será, na data da elaboração do relatório contábil, registrado, não só pelo valor de face originalmente praticado, mas também pelo acréscimo ou decréscimo relativo à flutuação da moeda estrangeira até aquela data. E assim se faz independentemente da liquidação daquele ativo e alheio à ampla possibilidade de não ser o montante a ser efetivamente quitado exatamente aquele valor até então registrado. A contrapartida do aumento ou decréscimo do ativo, no exemplo dado, será o reconhecimento, no resultado do exercício, de uma receita ou despesa financeira.

Do ponto de vista contábil, essa antiga técnica é merecedora de amplos elogios, na medida em que indica ao usuário a posição mais atualizada do ativo ou passivo sujeito à flutuação em moeda estrangeira, tornando o relatório contábil coerente com sua função de fornecer uma predição de fluxos de caixa futuros como meio para tomada de decisões. Para tanto, os contabilistas lançavam mão do "princípio do custo corrente".

Todavia, há que se ter em mente as seguintes ressalvas apontadas por José Antonio Minatel:

359 IUDÍCIUS, Sérgio de; GELBCKE, Ernesto Rubens; MARTINS, Eliseu. Manual de Contabilidade Societária. São Paulo: Atlas, 2010. p. 464. 
“Todos os demais ajustes intermediários e periódicos, realizados antes da efetiva liquidação do contrato de câmbio, seja nas contas representativas de direito de crédito, seja nas contas de obrigações, melhor se aproximam do conceito técnico de simples "provisões", por traduzirem meras expectativas que ainda dependem de confirmação em eventos futuros e incertos, não revelando, no momento do ajuste, qualquer nova disponibilidade definitiva (variações ativas), tampouco efetiva exigibilidade das obrigações (variações passivas)." 360

Veja-se, portanto, que as "receitas" ou "despesas" financeiras conexas às variações cambiais nada mais representam do que meras expectativas fundamentadas em flutuações do valor praticado da moeda. E, como tais, são destituídas de toda certeza e definitividade inerentes à segurança jurídica almejada pelo Constituinte originário, de modo que a tributação desse "ganho" contábil, por tudo o que se expôs até o presente momento neste trabalho, não é compatível com os princípios da capacidade contributiva e da igualdade.

Vitor Borges Polizelli, em sua dissertação de mestrado apresentada à Faculdade de Direito da Universidade de São Paulo, tem o sentir de que "a tributação da variação de valor de ativos inerentes (ganhos ou perdas de detenção) (....) atenderia aos ideais de igualdade e tributação conforme a capacidade contributiva" ${ }^{361}$, admitindo a adoção do conceito de renda-acréscimo patrimonial em sua amplitude (o modelo SHS) para fins de tributação.

Já tivemos a oportunidade, noutro lugar ${ }^{362}$, de discorrer e criticar o modelo SHS para fins tributários, todavia, não é demais sublinhar que a igualdade, nessa hipótese, estaria ofendida, posto que o contribuinte sujeito à variação cambial positiva estaria em situação diferenciada (e inferiorizada) em relação a outro contribuinte sujeito à tributação por uma ganho efetivamente realizado. Enquanto o "ganho" do primeiro estaria sujeito à eventos futuros e - destaca-se - absolutamente incertos, o segundo já teria experimentado um aumento de seu patrimônio pelo ingresso de novos direitos frutos de, mais das vezes, realização de transações com terceiros em condições normais de mercado. O segundo teria,

\footnotetext{
360 MINATEL, José Antonio. Conteúdo do Conceito de Receita e Regime Jurídico para a sua Tributação. São Paulo: MP Editora, 2005. p. 236.

361 POLIZELLI, Victor Borges. O Princípio da Realização da Renda e sua Aplicação no Imposto de Renda das Pessoas Jurídicas. Dissertação. Mestrado. Universidade de São Paulo, 2009. p. 225.

${ }^{362}$ Cf. item 3.2.5., acima.
} 
portanto, de contribuir com as despesas gerais do Estado mesmo diante da - não descartável - possibilidade de não ver realizado o aumento de seu patrimônio.

Por conta disso, merecem elogios as decisões de nossa jurisprudência que não admitem a tributação da variação cambial antes de sua efetiva realização. O STJ, por meio do REsp 320455/RJ assim se pronunciou:

“TRIBUTÁRIO - IMPOSTO DE RENDA - VARIAÇÕES CAMBIAIS CONSIDERADAS COMO RENDA ANTES DO PAGAMENTO DA OBRIGAÇÃO - MOMENTO DA DISPONIBILIDADE ECONÔMICA INCIDÊNCIA DO TRIBUTO.

O Imposto de Renda só incide sobre os ganhos decorrentes de variações cambiais quando realizado o pagamento das obrigações financeiras relativas àquelas variações, porque é a partir daí que serão incluídos na receita e na apuração do lucro real obtido.

Recurso improvido."

São pródigas as palavras do Ministro Relator Garcia Vieira para justificar sua decisão, particularmente quanto a seu sentir no que tange à qualificação das variações cambiais como meras expectativas de ganho futuro:

"Partindo de tais pressupostos, sem a necessidade de maiores digressões, de ordem doutrinária, afigura-se-me escorreita a decisão ora objurgada, porquanto é certo que a disponibilidade econômica ou jurídica da renda só ocorre quando houver real acréscimo patrimonial, não cabendo a tributação sobre mera expectativa de ganho futuro e em potencial." (destaques nossos)

Outra importante passagem do voto diz respeito ao ponto de divergência entre o registro contábil das variações cambiais e o acréscimo patrimonial exigido pelo artigo 43 do CTN. Nos trechos abaixo há expressa manifestação no sentido de que o regime contábil, por si só, não teria o condão de relevar capacidade contributiva. Vejamos o voto relator, aderindo às alegações da recorrida por meio do contrarrazões:

"Assim, tem-se que, o efetivo acréscimo patrimonial, disponibilizado para o contribuinte, não pode ser verificado pelos registros contábeis, mas somente pelo ganho determinado no momento em que a Recorrida cumprir a obrigação financeira, pois é somente nesse momento que ela se beneficia (ou não) com a quantidade de reais necessária para a liquidação da obrigação em moeda estrangeira. Antes disso, os registros contábeis significam, tão somente, mera 
expectativa de ganho, que não constitui hipótese de incidência do imposto de $\underline{\text { renda. }}$

Como viu-se acima, a disponibilidade a que se refere o art. 43 do CTN resulta de um fator econômico concreto e atual (dinheiro em caixa por exemplo) ou de um fato reconhecido como tal pelo Direito (um direito reconhecido pela lei, como o direito de crédito).

Logo, não há como se falar que meros registros contábeis, que representam tão $\underline{\text { somente expectativas de resultado positivo (já que não se sabe se quando a }}$ obrigação for cumprida, a variação será positiva ou negativa) constituam um acréscimo patrimonial, e que este, por força do regime de competência, esteja disponibilizado para o contribuinte no momento em que registrado; ao contrário, é certo que o contribuinte não dispõe desse ganho, uma vez que ainda não implementado o termo em que deveria cumprir sua obrigação financeira." (destaques nossos)

Atualmente, a legislação do IRPJ (também aplicável ao regime das contribuições sociais sobre o lucro, Programa de Integração Social e do Financiamento da Seguridade Social - CSLL, PIS e COFINS) faculta aos contribuintes optarem pela tributação (ou dedutibilidade) das variações cambiais ativas (ou passivas) no momento de sua efetiva liquidação ${ }^{363}$ (regime de caixa), tal como defendemos linhas acima.

Ademais, a partir de 2011, com a instituição da Lei nº 12.249/10, a opção pela forma de tributação (se pelo regime de caixa ou de competência) passou a ser exercida em janeiro de cada exercício, por meio de entrega de obrigação acessória. Tal opção, nos termos da indigitada lei, reveste-se de caráter irretratável, salvo nos casos em que ocorra elevada oscilação da taxa de câmbio, assim entendido determinado percentual indicado pelo Poder Executivo.

Com efeito, o que se impõe discutir é se, por um equívoco do contribuinte no preenchimento de uma dentre tantas obrigações acessórias atualmente vigentes no Brasil, haveria motivos para litigar contra a consequente tributação da variação cambial antes de sua efetiva realização durante todo o exercício.

Parece-nos que a resposta é, imperativamente, positiva. É de se notar que, em realidade, a "opção" de oferecer à tributação a variação cambial pelo regime de caixa nada mais é do que uma obrigação requerida pelos princípios que norteiam o Direito Tributário

363 Medida Provisória no 2.158-35, artigo 30. 
Brasileiro, como medida de igualdade e justiça tributária. Noutras palavras, de opção não se trata, mas sim de um mandamento dirigido ao legislador tributário.

Portanto, não se pode, à guisa de uma infeliz manifestação de opção exercida pelo contribuinte, incluir na base de cálculo do IRPJ algo que não representa uma grandeza compatível com o princípio da capacidade contributiva, notadamente quando se está diante de um erro cometido pelo contribuinte no preenchimento de uma obrigação acessória.

A prova do efetivo erro cometido poderia ser demonstrada, por exemplo, pelo histórico de manutenção do trabalhoso controle de variações cambiais liquidadas, que serve de base para ajustes ao Lucro Líquido com fins à determinação do Lucro Real. Ora, não parece conveniente demandar demasiado tempo na manutenção de controle desse tipo para, num único ano-calendário isolado e sem explicação plausível, optar-se pelo regime de caixa.

Tratar-se-ia, portanto, daquilo que em ciência jurídica aludimos como "erro de fato", isto é, “diria respeito à utilização inadequada das técnicas lingüísticas de certificação dos eventos" 364 .

Nessa hipótese, abrir-se-ia, então, espaço para a superação da regra contida na Lei $n^{\circ} 12.249 / 10$, isto é, sua inobservância num dado caso concreto em virtude de especial ponderação do aplicador da lei. Assim sendo, pertinente é a seguinte advertência de Humberto Ávila: “(...) as regras também envolvem valores e carecem de ponderação, podendo, em circunstâncias excepcionais, ser superadas." 365

Ressalte-se, ainda, que a desconsideração de erros no preenchimento de obrigações acessórias em prol da verdadeira intenção do contribuinte não seria inédita na jurisprudência administrativa federal brasileira, consoante demonstram os seguintes precedentes administrativos:

\section{“IRPJ - ERRO NO PREENCHIMENTO DA DIRPJ.}

Na parcela comprovada do erro de fato cometido no preenchimento da DIRPJ, faz-se mister agasalhar a correção promovida pela retificadora. Inexistência de ofensa ao art. 147 do CTN, apesar de a retificação se dar após o lançamento. Não se cuida de retificação por iniciativa do contribuinte, mas de consectário

\footnotetext{
${ }^{364}$ Cf. CARVALHO, Paulo de Barros. Direito Tributário: Fundamentos Jurídicos de Incidência. 3. ed. São Paulo: Saraiva, 2004. p. 100.

365 ÁVILA, Humberto. Teoria dos Princípios. Da definição à aplicação dos princípios jurídicos. 11.ed. São Paulo: Malheiros, 2010. 114.
} 
da questão controvertida instalada. Ademais, não se está diante de lançamento por declaração.”

CARF / 1 $1^{\mathrm{a}}$ Seção / $3^{\mathrm{a}}$ Turma da 1ª Câmara / Acórdão 1103-00.490 em $29 / 06 / 2011$

"DECLARAÇÃO DE COMPENSAÇÃO. ERRO DE FATO. Provada a existência de notório erro de fato cometido pela interessada no preenchimento de sua declaração de compensação (DCOMP), relativo ao período de apuração do saldo negativo de IRPJ ali informado, por ser de fácil verificação pela autoridade de primeira instância e não depender de dilação probatória, deve ser por esta reconhecido.

Vistos, relatados e discutidos os presentes autos.

Acordam os membros do colegiado, por maioria de votos, em DAR provimento parcial ao Recurso para determinar o retorno dos autos à autoridade julgadora de primeira instância para análise das questões de mérito."

CARF / $1^{\mathrm{a}}$ Seção / $1^{\mathrm{a}}$ Turma da $2^{\mathrm{a}}$ Câmara / Acórdão 1201-00.520 em $27 / 05 / 2011$

"IRRF - COMPENSAÇÃO - ERRO NO PREENCHIMENTO DIPJ PRINCÍPIO DA VERDADE MATERIAL - Tendo sido devidamente comprovado nos autos, através da diligência fiscal realizada, que a contribuinte cometeu erro de fato no preenchimento de sua Declaração de Rendimentos, em observância ao principio da verdade material, deve ser reconhecido o direito creditório em favor da contribuinte. Recurso Voluntário Procedente."

CARF - $1^{\mathrm{a}}$ Seção $-1^{\mathrm{a}}$ Turma da $1^{\mathrm{a}}$ Câmara / Acórdão 1101-00.132 em $18 / 06 / 2009$

"IRPJ - PREJUÍZO FISCAL - IRRF - RESTITUIÇÃO DE SALDO NEGATIVO - ERRO DE FATO NO PREENCHIMENTO DA DIPJ PREVALÊNCIA DA VERDADEMATERIAL - Não procede o não reconhecimento de direito creditório relativo a IRRF que compõe saldo 
negativo de IRPJ, quando comprovado que a receita correspondente foi oferecida à tributação, ainda que em campo inadequado da declaração.

Recurso provido.

Por unanimidade de votos, DAR provimento ao recurso."

$1^{\circ}$ Conselho de Contribuintes / $5^{\mathrm{a}}$ Câmara / Acórdão 105-16.286 em 28.02.2007

De todo modo, quer-nos parecer que o reflexo em resultado do exercício da atualização monetária em virtude de flutuação cambial, embora indispensável da perspectiva do usuário da contabilidade, não tem o condão de, por si só, demonstrar aptidão de aumento de patrimônio antes da efetivada a liquidação da operação desencadeadora da respectiva variação. Se assim é, mais uma vez restaria demonstrada a incompatibilidade entre a visão contábil do patrimônio e a perspectiva jurídica, de modo que, para efeitos de apuração do IRPJ, o legislador não poderia deixar de acolher ajuste específico se apontar o lucro contábil como marco inicial para apuração do referido imposto.

\subsubsection{GANHO EM COMPRA VANTAJOSA}

Já abordamos neste trabalho ${ }^{366}$ que, diante de uma combinação de negócios, o ágio por rentabilidade futura (goodwill) ou o ganho em compra vantajosa (o antigo deságio) passou a ser, grosso modo, a diferença entre o valor de aquisição do investimento e o valor líquido avaliado pelo valor justo, na data da aquisição, dos ativos identificáveis adquiridos e dos passivos assumidos.

Sendo a diferença a maior, vale dizer, se o valor da aquisição superar o valor líquido do investimento avaliado pelo valor justo, estaremos diante da figura do ágio por rentabilidade futura (goodwill), registrável em conta de ativo intangível e somente sujeito à baixa para resultado do exercício por meio de avaliação da redução ao valor recuperável (impairment test).

Por outro lado, tratando-se de diferença a menor, ou seja, se o valor da aquisição não superar o valor do investimento avaliado pelo valor justo, exsurgirá a figura do ganho em compra vantajosa. Significa que o montante que superar o valor do

\footnotetext{
${ }^{366}$ Cf. item 5.3.3.2.3.
} 
investimento será registrado diretamente em conta do resultado do exercício, por meio de um lançamento a crédito. Assim, a entidade reconhecerá uma receita, aumentando o lucro do exercício.

Perceba-se, portanto, que, do ponto de vista contábil, está extinta a figura do deságio, que representava a contrapartida, em conta do ativo, da diferença a menor entre o valor da aquisição e o valor do investimento. Significa que, em perspectiva puramente contábil em relação ao deságio, não mais faz sentido a segregação do custo de investimento de que trata o artigo 385 do RIR/99:

"Art. 385. O contribuinte que avaliar investimento em sociedade coligada ou controlada pelo valor de patrimônio líquido deverá, por ocasião da aquisição da participação, desdobrar o custo de aquisição em (Decreto-Lei $\mathrm{n}^{\circ} 1.598$, de 1977, art. 20):

I - valor de patrimônio líquido na época da aquisição, determinado de acordo com o disposto no artigo seguinte; e

II - ágio ou deságio na aquisição, que será a diferença entre o custo de aquisição do investimento e o valor de que trata o inciso anterior.

$(\ldots) "$

Em suma, se antes do novo padrão contábil brasileiro, inaugurado pela Lei $n^{\circ}$ 11.638/07, a diferença a menor do valor de aquisição e o do investimento era tratada como deságio, registrado contabilmente em conta credora do ativo (ou seja, não havia, de imediato, impacto no resultado do exercício), com o procedimento previsto no Pronunciamento CPC 15, há o reconhecimento de um ganho no resultado do exercício, aumentando, via de consequência, o lucro naquele período.

Por certo, atualmente, por força do RTT, o ganho por compra vantajosa, inexoravelmente, deveria ser concebido como um ajuste negativo, o que neutralizaria fiscalmente esse registro contábil. Todavia, caso o Brasil adotasse o modelo de dependência total, a questão que surge é se esse ganho poderia, ou não, representar um aumento da base de cálculo do IRPJ.

Nossa opinião é, em respeito à coerência com o que até aqui foi escrito, negativa.

Em primeiro lugar, deve ser ponderado que a aquisição onerosa de um ativo, por si só, não tem o condão de aumentar o patrimônio de uma pessoa. Isso porque, se por um lado, a própria aquisição do ativo constitui o ingresso de um direito novo ao 
patrimônio, por outro lado, esse direito está, inexoravelmente, ligado a um sacrifício de outro ativo. À guisa de exemplo, se uma pessoa jurídica adquirir a maioria das ações de outra pessoa jurídica por $\$ 1.000,00$, o que ocorre é o ingresso de um novo direito ao patrimônio da pessoa jurídica adquirente (ações da pessoa jurídica investida) umbilicalmente ligado ao sacrifício de um ativo seu $(\$ 1.000,00)$. Assim, considerando esses dois elementos conjuntamente, pode-se afirmar que não há aumento de patrimônio, na medida em que o ingresso de um direito está ligado ao sacrifício de outro.

Ademais, não nos convenceria o argumento de que se verifica um aumento de patrimônio na hipótese de o direito novo incorporado ao patrimônio ter valor de mercado (ou valor justo na prática contábil contemporânea) superior ao sacrifício do ativo contraprestacional. Em realidade, nessa situação, nada mais há do que aquilo que já abordamos anteriormente no que tange à renda psíquica $^{367}$, ou seja, um fluxo de sentimentos de satisfação que os indivíduos têm do consumo de bens e $\operatorname{serviços}^{368}$. Na hipótese agora aventada, há, quando muito, um mero sentimento de satisfação do adquirente, o qual, por si só, não é suficiente para relevar capacidade de contribuir com as despesas gerais do Estado por meio de pagamento de impostos.

Somente haveria ganho tributável se e quando o adquirente resolver implementar a venda para terceiros do ativo anteriormente adquirido por valor superior ao de mercado. O ganho, portanto, seria o resultado líquido do valor da alienação e do custo de aquisição do ativo. Em outras palavras, somente há ganho, na perspectiva jurídica, após a realização do ativo anteriormente adquirido. Antes disso, somente há mera satisfação interna (psíquica) por ter realizado um negócio compensador, o qual, por si só, não pode servir de parâmetro para que o Estado exija contribuição às despesas gerais, sob pena de ofensa à mais comezinha noção de igualdade entre os cidadãos.

Se assim é, e nos socorrendo dos argumentos acima expostos, podemos concluir que o ganho na compra vantajosa no contexto da combinação de negócios, embora denominado com "ganho" para efeitos do Pronunciamento CPC 15, pode trazer uma satisfação de renda, a qual, todavia, não é suficiente para despertar a sanha arrecadatória do Estado, sob pena de se tributar mera renda psíquica, conflitando com o Princípio Constitucional da Igualdade na Tributação.

\footnotetext{
${ }^{367}$ Cf. item 3.2.4.

${ }^{368}$ Cf. HOLMES, Kevin. The Concept of Income. A Multi-Disciplinary Analysis. The Netherlands. IBFD Publications BV, 2000. ps. 36 e 37.
} 
Por conta desses argumentos, somos obrigados a, uma vez mais, chamar a atenção para o fato de que a contabilidade poderá reconhecer um ganho, que, ainda que coerente com a sua perspectiva e objetivos, não pode ser confundido com um fenômeno a ser tributado pelo imposto de renda. Com efeito, o legislador, ao prescrever a base de cálculo do IRPJ, não poderá se deslembrar de promover um ajuste para neutralizar uma manifesta injustiça ao contribuinte.

\subsubsection{GANHO NA VARIAÇÃO DE PERCENTUAL DE PARTICIPAÇÃO SOCIETÁRIA}

Pela coerência com as premissas encartadas durante todo este trabalho, causam-nos certo desconforto as razões de decidir contidas no Acórdão $n^{\circ}$ 1202-00.225 prolatado pelo CARF, que tinha por objeto litigioso a tributação, na sistemática do Lucro Presumido, do ganho na variação de percentual de participação societária.

Antes de adentrarmos no mérito do precedente em questão, cabe-nos principiar descrevendo que a variação de percentual de participação societária, que pode gerar tanto ganho como perda, decorre da aplicação do MEP. De acordo com o artigo 248 da LSA:

“Art. 248. No balanço patrimonial da companhia, os investimentos em coligadas ou em controladas e em outras sociedades que façam parte de um mesmo grupo ou estejam sob controle comum serão avaliados pelo método da equivalência patrimonial, de acordo com as seguintes normas: (Redação dada pela Lei $n^{\circ} 11.941$, de 2009)

I - o valor do patrimônio líquido da coligada ou da controlada será determinado com base em balanço patrimonial ou balancete de verificação levantado, com observância das normas desta Lei, na mesma data, ou até 60 (sessenta) dias, no máximo, antes da data do balanço da companhia; no valor de patrimônio líquido não serão computados os resultados não realizados decorrentes de negócios com a companhia, ou com outras sociedades coligadas à companhia, ou por ela controladas; 
II - o valor do investimento será determinado mediante a aplicação, sobre o valor de patrimônio líquido referido no número anterior, da porcentagem de participação no capital da coligada ou controlada;

\section{$(\ldots) "$}

Com efeito, o investimento em coligadas, controladas ou outras empresas do mesmo grupo será registrado, pela companhia investidora, pelo valor do patrimônio líquido proporcionalmente à sua participação societária. Significa que as variações do patrimônio líquido da investida, automaticamente, serão refletidas na contabilidade da investidora. Se houver variação positiva, a investidora reconhecerá um resultado positivo de equivalência patrimonial, ao passo que, se se verificar variação negativa, reconhecer-se-á resultado negativo de equivalência patrimonial.

Outra hipótese de alteração no valor do investimento pelo MEP é a variação de percentual de participação societária. Isso pode ocorrer em algumas situações, como nos seguintes exemplos: (i) aumento de capital social sem o exercício do direito de preferência de todos os acionistas/sócios; (ii) retirada de acionista/sócio com valor abaixo do patrimonial; (iii) aumento do patrimônio líquido por aumento de capital social por subscrição com ágio.

Para melhor compreensão do primeiro (e mais comum) caso, socorremo-nos do exemplo trazido por Iudícibus e et. al.:

"Suponha que, quando da constituição da Empresa B, um de seus acionistas, a Empresa A, tenha integralizado 900 ações ordinárias, o que representa $30 \%$ do capital social realizado da Empresa B no valor de \$3.000, formado apenas por ações ordinárias. (...) Considere ainda que, a Empresa A possui influência significativa sobre a Empresa B e que, em 31-12-X0, o Patrimônio Líquido da Empresa B tenha o valor de $\$ 5.000$ por lucro não distribuído.

A Empresa A avalia seu investimento por equivalência patrimonial e sua conta de Investimento em Coligadas, nessa mesma data, estaria com saldo de \$ 1.650 , ou seja, $30 \%$ de $\$ 5.500$.

Suponha, agora, que durante X1 a Empresa B faça um aumento de capital por subscrição de 1.000 novas ações no valor de $\$ 1.000$, e que seja totalmente subscrito pela Empresa A, já que os demais acionistas que detinham os outros $70 \%$ não exerceram seu direito de preferência. Assim, o Capital da Empresa B 
estaria então com 4.000 ações, das quais $1.900(900+1.000)$ são pertencentes à Empresa A, que passa, agora, a ter 47,5\% do Capital de B, em vez dos $30 \%$ anteriores.

Dessa forma, a conta de Investimentos em Coligadas, na Empresa A, pela equivalência patrimonial, passa de um saldo de \$1.650 para \$3.087,50." 369

Veja-se, portanto, que o aumento de capital de um dos acionistas/sócios, sem que os outros tenham exercido seu direito de preferência, resultou num aumento do investimento pelo MEP, uma vez aumentada a variação do percentual de participação societária. A contrapartida desse aumento, antes do novo padrão contábil inaugurado pela Lei $\mathrm{n}^{\mathrm{o}}$ 11.638/07, era registrado em conta de resultado do exercício. Atualmente, por força do item 11 do Pronunciamento CPC 18, a contrapartida é reconhecida em conta do patrimônio líquido ${ }^{370}$.

Do ponto de vista fiscal, o artigo 428 do RIR/99 garante, aos contribuintes optantes pelo Lucro Real, o direito à exclusão do ganho ou adição da perda decorrente da variação na participação societária, consoante se percebe do texto abaixo transcrito:

“Art. 428. Não será computado na determinação do lucro real o acréscimo ou a diminuição do valor de patrimônio líquido de investimento, decorrente de ganho ou perda de capital por variação na percentagem de participação do contribuinte no capital social da coligada ou controlada (Decreto-Lei ${ }^{\circ} 1.598$, de 1977 , art. $33, \S 2^{\circ}$, e Decreto-Lei ${ }^{\circ} 1.648$, de 1978, art. $1^{\circ}$, inciso V).

\section{$(\ldots) "$}

O caso julgado por ocasião do Acórdão n 1202-00.225, prolatado pelo CARF, traz à baila a discussão sobre se a regra acima poderia, ou não, ser aplicada aos contribuintes optantes pelo Lucro Presumido. Trata-se de autuado que, optante pelo Lucro Presumido, teve o valor da conta investimento aumentado devido ao aumento de patrimônio líquido de sua investidora decorrente de aumento de capital, por um outro sócio, com subscrição de ágio, registrado em conta de reserva de capital.

A discussão girou em torno da aplicação da regra geral de tributação de outras receitas pela sistemática do Lucro Presumido (artigo 521 do RIR/99) ou pela potencial

369 IUDÍCIUS, Sérgio de; GELBCKE, Ernesto Rubens; MARTINS, Eliseu. Manual de Contabilidade Societária. São Paulo: Atlas, 2010. P. 177.

${ }^{370}$ Cf. IUDÍCIUS, Sérgio de; GELBCKE, Ernesto Rubens; MARTINS, Eliseu. Manual de Contabilidade Societária. São Paulo: Atlas, 2010. P. 177. 
regra específica que retiraria da abrangência de oneração os ganhos decorrentes de variação no percentual de participação societária. Conforme descreveu o relator do Acórdão, Conselheiro Cândido Rodrigues Neuber:

"51. Tendo a contribuinte optado pela tributação com base no Lucro Presumido, é de se aplicar ao caso as disposições da Lei n ${ }^{\circ} 9.430$, de 27 de dezembro de 1996, que assim dispõem:

'Seção VI - Lucro Presumido

Determinação

Art. 25. O lucro presumido será o montante determinado pela soma das seguintes parcelas:

1- o valor resultante da aplicação dos percentuais de que trata o art. 15 da Lei ${ }^{\circ} 9.249$, de 26 de dezembro de 1995 , sobre a receita bruta definida pelo art. 31 da Lei $\mathrm{n}^{\circ} 8.981$, de 20 de janeiro de 1995, auferida no período de apuração de que trata 0 art. $1^{\circ}$ desta Lei;

II - os ganhos de capital, os rendimentos e ganhos líquidos auferidos em aplicações financeiras, as demais receitas e os resultados positivos decorrentes de receitas não abrangidas pelo inciso anterior e demais valores determinados nesta Lei, auferidos naquele mesmo período' (...).

52. As normas aplicáveis ao ganho de capital e outras receitas na tributação com base no lucro presumido encontram-se consolidadas no art. 521 do Regulamento do Imposto de Renda, aprovado pelo Decreto $\mathrm{n}^{\circ} 3.000$, de 26 de março de 1999 - RIR/1999, nos seguintes termos:

'Art. 521. Os ganhos de capital, os rendimentos e ganhos líquidos auferidos em aplicações financeiras, as demais receitas e os resultados positivos decorrentes de receitas não abrangidas pelo art. 519 [receita bruta], serão acrescidos à base de cálculo de que trata este Subtítulo, para efeito de incidência do imposto e do adicional, observado o disposto nos arts. 239 e 240 e no $\$ 3^{\circ}$ do art. 243 , quando for o caso' (...).

53. Diante das expressas disposições acima, não se configura juridicamente possível a aplicação ao caso do disposto no art. 428, do mesmo Decreto regulamentar, que prescreve a exclusão da tributação, com base no lucro real, do acréscimo decorrente de ganho ou perda de capital por variação na percentagem de participação da autuada no capital social da controlada. 
54. Como bem destacou a fiscalização, não se pode ampliar a norma aplicável apuração do lucro real para o presumido, principalmente porque, mesmo sem adentrar na discussão acerca do caráter isencional da norma veiculada pelo art. 428 do RIR, de 1999, é indubitável que o ganho ou perda de capital sob apreciação, somente pode ser excluído do lucro real, por causa da existência de norma expressa dispondo a respeito, fato que vem reforçar o entendimento de que tal fato jurídico não se insere propriamente no campo da não-incidência tributária do imposto de renda.

55. Portanto, para que fosse admitida exclusão da base de cálculo do lucro presumido do ganho não-operacional obtido com a aplicação do método da equivalência patrimonial, haveria que existir disposição expressa nesse sentido, o que conforme exposto acima não se verifica no ordenamento em vigor."

Dado o escopo de nosso trabalho, não nos interessa, neste momento, outros aspectos presentes no julgamento em tela, como, por exemplo, a existência, no caso concreto, de operações sequenciais (resgate de ações da investidora imediatamente após o aumento de capital com ágio, o que poderia dar ensejo à discussão sobre eventual dissimulação de ganho de capital). Ademais, também não nos interessa aqui a interpretação, de per si, do artigo 428 do RIR/99, especialmente se aplicável, ou não, aos contribuintes optantes pelo Lucro Presumido.

Em realidade, o que nos orienta agora é discorrer sobre se, a despeito do reconhecimento contábil de uma receita no resultado do exercício ${ }^{371}$, o ganho decorrente de variação no percentual de participação societária poderia, ou não, ser ensejadora de renda na perspectiva constitucional.

Em nosso sentir, o ganho contábil em voga não é hábil em relevar, por si só, capacidade contributiva da investidora, uma vez que inexiste, imediatamente, aquisição de novos direitos a ensejar aumento de patrimônio na perspectiva jurídica.

Do contrário, teríamos de admitir que o investimento (aumento de capital), por si só, seria revelador de aumento de patrimônio. Todavia, em perspectiva jurídica, significa um novo direito (propriedade de quinhão societário) intimamente ligado a um sacrifício anterior (direito sobre a parcela que foi subscrita). Seria o mesmo de admitir um imposto

\footnotetext{
${ }^{371}$ Reiteramos que, por força de interpretação do CPC 18, item 11, não há mais que se falar, contabilmente, em registro do ganho no resultado do exercício, mas sim diretamente em conta de patrimônio líquido.
} 
sobre capital social, não admitido pela $\mathrm{CF} / 88$, ao menos sem uma lei complementar que o sustente.

Ademais, poder-se-ia argumentar que o aumento de capital daria direito a uma parcela de dividendos superior ao status anterior. Por certo sim, porém, como deixamos explicitado no item 6.3.3, os dividendos somente deixam de se caracterizarem como meras expectativas de direito após, por exemplo, expressa autorização de assembléia de acionistas ou do estatuto social.

Sendo assim, somos de opinião de que o ganho decorrente de variação de percentual de participação societária não é, por si só, suficiente para demonstrar capacidade contributiva, ainda que, do ponto de vista puramente contábil, exista um aumento no valor do investimento avaliado pelo MEP.

Essa conclusão é aplicável, inclusive, para o regime do Lucro Presumido, ainda que ausente previsão legal expressa para excluir o ganho de variação de participação societária em sua base de cálculo. O fato de essa sistemática ser aceitável em nosso ordenamento jurídico em nome, inclusive, da prevenção contra os desequilíbrios da concorrência (artigo 146-A da CF/88), não significa que o legislador ordinário possa, ao seu completo arbítrio, incluir, na base de cálculo do IRPJ, fenômeno completamente alheio ao conceito de renda constitucional minimamente aceitável. 


\section{CONCLUSÕES FINAIS}

1. A contabilidade pode ser entendida como sistema de informação e avaliação, destinado a prover seus usuários com demonstrações e análises de natureza econômica, financeira, física e de produtividades, relativas à entidade objeto de contabilização.

2. Ao longo dos tempos, foi ela sofrendo modificações de acordo com o surgimento de novos usuários e de suas necessidades ligadas às transformações culturais e econômicas do mundo.

3. A despeito de diversos usuários e de suas necessidades específicas, constatouse um interesse comum na predição de fluxos de caixa futuros como meio para tomada de decisões.

4. Por conta disso, a contabilidade foi (e ainda está) evoluindo para uma direção tendente a servir como um instrumento de informação para que os usuários possam, por meio das demonstrações contábeis, avaliar a capacidade que a entidade tem para gerar caixa e equivalentes de caixa e, então, tomar decisões prospectivas.

5. Tal evolução da contabilidade foi denominada information approach ou perspectiva da informação, que foi fortemente impulsionada por um movimento surgido nos Estados Unidos da América, a partir dos anos 1960 e que revolucionou o estudo da contabilidade. A contabilidade passou a ser vista sob a perspectiva da informação eseu papel seria o de informar os usuários externos das demonstrações.

6. Inspirado por esses valores e objetivos é que se faz contabilidade no Brasil, notadamente a partir de 2008, com a vigência da Lei $n^{\circ} 11.638 / 07$, que eliminou barreiras para a incorporação do padrão internacional regulamentado pelo IASB. É sob essa perspectiva que se deve encarar a juridicização da contabilidade pela LSA.

7. Tendo em vista essa perspectiva, a contabilidade não está adstrita - e nem poderia estar - a ser fiel e indissociável reflexo do patrimônio das companhias, assim entendido em sua acepção estritamente jurídica. Não tem ela esse compromisso, sob pena de deixar de atender seus propósitos, primordialmente o de bem informar seus usuários sobre futura geração de caixa.

8. $\quad \mathrm{O}$ que se tem observado é que os padrões internacionais de contabilidade prescindem de quaisquer razões ou fundamentos jurídicos, afastando-se da essência jurídica do negócio. A contabilidade, de uma vez por todas, desvinculou-se das influências do regime jurídico, passando a idealizar um sem número de eventos. Para enxergar a realidade, a contabilidade mune-se de suas próprias lentes, distintas da visão do jurista. 
9. Exatamente por isso, não pode o aplicador do direito se descuidar na compreensão da contabilidade, notadamente para não correr o risco de atribuir à técnica da primazia da essência sobre a forma (e, em última instância, à própria contabilidade) o poder de constituir-se num infalível e autossuficiente instrumento revelador de vícios jurídicos. Tal técnica não denuncia, por si só, a prática de engenharia jurídica artificialmente produzida com o objetivo de contornar lei imperativa ou outra forma de vício jurídico.

10. Em realidade, pode sim o contabilista, sob os auspícios da primazia da essência sobre a forma, idealizar o negócio jurídico retratado e registrá-lo à semelhança de outro. Assim é admitido porque tal proceder tem por finalidade tornar o relatório contábil mais eficiente para análise prospectiva da entidade.

11. Tradicionalmente, o Direito Tributário tem se valido da juridicização da contabilidade, tanto no toca a servir de relevante instrumento de prova, quanto à mensuração da base de cálculo dos tributos. Nesse último particular, a determinação da base de cálculo do IRPJ tem como ponto de partida o lucro líquido do exercício apurado de acordo com a LSA.

12. Todavia, cotejando-se a disciplina constitucional do imposto de renda e a atual perspectiva da contabilidade (juridicizada pelo Direito Societário), parece-nos que, no Brasil, não é possível admitir o modelo de dependência total, isto é, a adoção do lucro contábil-societário como base de cálculo do IRPJ sem nenhuma correção ou limitação no seu processo de determinação.

13. O lucro contábil-societário, sem nenhuma correção, infirmaria o aspecto material do imposto de renda, sobretudo porque, enquanto a contabilidade tem seus olhos voltados para o fluxo futuro de caixa, a tributação da renda deve projetar suas forças para os êxitos já alcançados (no presente, com o perdão da redundância), sob pena de colidir com o estado ideal de coisas a ser preservado pelo princípio da capacidade contributiva.

14. Isso porque a apuração do Lucro Tributável deve pautar-se pela conformação jurídica das relações jurídicas, e não por uma idealização econômico-informacional levada a efeito pela contabilidade.

15. A contabilidade, na atual perspectiva, não se presta à apuração da base de cálculo do IRPJ, posto que se distanciou dos conceitos jurídicos de patrimônio, necessários para a compreensão do aspecto material do imposto de renda. Por assim ser, não pode o legislador ordinário se omitir na prescrição de ajustes ao lucro líquido do exercício, de 
maneira a tornar o montante apurado de acordo com a lei societária compatível com o aspecto material do imposto de renda constitucionalmente pressuposto.

16. Exemplos de ajustes que devem ser obrigatoriamente constantes na legislação tributária são os relativos aos seguintes efeitos contábeis: AVP, arrendamento mercantil, equivalência patrimonial, ativos biológicos, instrumentos financeiros, variação cambial, ganho na aquisição de negócios vantajosos e ganho na variação de percentual de participação societária.

17. A técnica do AVP não pode ter reflexos na determinação do IRPJ, eis que há manifesto conflito entre a perspectiva jurídica e a contábil. A despeito dos benefícios do AVP aos usuários da contabilidade, há uma distorção da realidade jurídica e, via de consequência, parece-nos que, nesse ponto, o instrumental contábil para determinação da base de cálculo do IRPJ infirma o aspecto material pressuposto constitucionalmente. Notese que, juridicamente falando, não se pode conceber que toda e qualquer compra e venda a prazo seja uma produção jurídica artificial, com o intento de dissimular duas operações: uma compra e venda à vista e um contrato de empréstimo. Destarte, se na perspectiva jurídica se trata de um único negócio, a apuração do IRPJ não pode se desvincular dessa realidade.

18. Quanto ao arrendamento mercantil, o registro do bem no ativo, do ponto de vista informacional do usuário da contabilidade, é de extremo benefício, posto que melhor prevê o fluxo de caixa futuro da entidade, já que se espera o exercício futuro da opção de compra do bem. Todavia, o óbice à dedutibilidade da contraprestação pelo arrendamento mercantil infirmaria o aspecto material do imposto de renda, tendo em vista tratar-se de verdadeiro consumo (decréscimo) do patrimônio da entidade pelo direito de uso do bem. Parece-nos que o mandamento prescrito no artigo 11 da Lei ${ }^{\circ} 6.099 / 74$ nada mais é do que didático.

19. O modelo de dependência total não pode ser adotado para o caso dos lucros de coligadas e controladas, tendo em vista que (i) o lucro contábil apurado pela investida como se está a demonstrar neste trabalho - não necessariamente confirma o aspecto material do IRPJ; e (ii) os lucros apurados pela investida não representam direito adquirido da investidora. Quanto a este último aspecto, destaque-se que a deliberação societária que define a distribuição de dividendos não é mera formalidade jurídica. Veja-se que, não ocorrendo tal deliberação, pode ocorrer de tais lucros serem absorvidos por futuros prejuízos, ficando a investidora desprovida de capacidade contributiva. 
20. No que tange ao tema do ativo biológico, a avaliação dos estoques a valor justo, embora significativa para fins contábeis, eis que expõe aos usuários as expectativas de geração de caixa futuro, não tem o condão de, por si só, demonstrar aptidão para contribuir com as despesas gerais do Estado. Isso ocorrerá tão somente quando da transação dos produtos com terceiros, ocasião em que ingressarão no patrimônio da entidade novos direitos subjetivos.

21. Já no que diz respeito aos instrumentos financeiros mensurados pelo valor justo por meio de resultado, a contabilização da variação do valor de mercado (valor justo) pode representar mera expectativa de ganho, vale dizer, antes de sua efetiva realização e negociação com terceiros, não tem o condão de, por si só, possibilitar capacidade para contribuir com as despesas gerais do Estado. Não há aquisição de direitos subjetivos no bojo duma relação jurídica, pressuposto de renda constitucionalmente tributada.

22. A mensuração de ativo intangível no bojo de um contrato de concessão pelo valor justo, vale dizer, a partir de projeção realizada pela administração da companhia, pode não representar aquisição de aumento de patrimônio. Isso porque o direito à percepção da receita ocorre tão somente com o compromisso de pagamento pelos cidadãos pela efetiva utilização do serviço objeto da concessão.

23. Sobre as variações cambiais, constatamos que as "receitas" ou "despesas" financeiras conexas a elas nada mais representam do que meras expectativas fundamentadas em flutuações do valor praticado da moeda. E, como tais, são destituídas de toda certeza e definitividade inerentes à segurança jurídica almejada pelo Constituinte originário, de modo que a tributação desse "ganho" contábil, por tudo o que se expôs até o presente momento neste trabalho, não é compatível com os princípios da capacidade contributiva e da igualdade.

24. Ainda sobre esse tema, e levando em consideração a atual disciplina das variações cambiais em matéria fiscal, uma importante observação diz respeito ao fato de que a "opção" de oferecer à tributação pelo regime de caixa nada mais é do que uma obrigação requerida pelos princípios que norteiam o Direito Tributário Brasileiro, como medida de igualdade e justiça tributária. Destarte, não se pode, à guisa de uma infeliz manifestação de opção exercida pelo contribuinte, incluir na base de cálculo do IRPJ algo que não representa uma grandeza compatível com o princípio da capacidade contributiva, notadamente quando se está diante de um erro cometido pelo contribuinte no preenchimento de uma obrigação acessória. 
25. Já em relação ao ganho na compra vantajosa no contexto da combinação de negócios, embora denominado como "ganho" para efeitos do Pronunciamento CPC 15 e trazer um sentimento de satisfação pelo fato de adquirir um negócio por valor inferior ao justo, não é suficiente para contribuir com as despesas gerais do Estado. Nessa descabida situação, haveria tributação sobre a mera renda psíquica, conflitando com o Princípio Constitucional da Igualdade na Tributação.

26. Por fim, quanto ao ganho na variação de percentual de participação societária, o IRPJ não pode ser admitido, ainda que de contribuintes optantes pelo Lucro Presumido, uma vez que (i) não há, ao menos imediatamente, aquisição de novos direitos a ensejar aumento de patrimônio na perspectiva jurídica (ii) apesar de a sistemática de Lucro Presumido ser admitida em face de nosso sistema jurídico, não significa que o legislador ordinário possa, ao seu completo arbítrio, incluir na base de cálculo do IRPJ fenômeno completamente alheio ao conceito de renda constitucionalmente minimamente aceitável. 


\section{BIBLIOGRAFIA}

AMARO, Luciano. Direito Tributário Brasileiro. 14. ed. São Paulo: Saraiva, 2008.

ANDRADE FILHO, Edmar Oliveira. O direito contábil e a disciplina jurídica das demonstrações financeiras. São Paulo: Prognose Editora, 2010.

ARAGÃO, Paulo Cezar, ROCHA, Sergio André. Alteração dos Padrões Contábeis Brasileiros: A Neutralidade Fiscal Transitória, "Deslegalização" da Contabilidade e o Princípio da Legalidade Tributária. In: ROCHA, Sergio André (cood.). Direito Tributário, Societário e a Reforma da Lei das S/A. Vol. II. São Paulo: Quartier Latin, 2010.

ATALIBA, Geraldo. Sistema Constitucional Tributário Brasileiro. São Paulo: Revista dos Tribunais, 1968.

ÁVILA, Humberto. Regra-Matriz versus Princípios. In: Direito Tributário - Homenagem a Paulo de Barros Carvalho. São Paulo, Quartier Latin, 2008.

. Sistema Constitucional Tributário. 4.ed. São Paulo: Saraiva: 2010.

. Teoria dos Princípios. Da definição à aplicação dos princípios jurídicos.

11.ed. São Paulo: Malheiros, 2010.

Conceito de Renda e Compensação de Prejuízos Fiscais. São Paulo:

Malheiros, 2011.

BALEEIRO, Aliomar. Limitações Constitucionais ao Poder de Tributar. Notas de atualização de Misabel Abreu Machado Derzi. $7^{\text {a }}$ edição. Rio de Janeiro: Editora Forense, 1998.

Uma Introdução à Ciência das Finanças. $16^{\mathrm{a}}$ ed. rev. e atualizada por Dejalma de Campos. Rio de Janeiro, Forense, 2002.

BARRETO, Paulo Ayres. Contribuições - Regime Jurídico, Destinação e Controle, São Paulo: Noeses, 2006.

. Elisão Tributária: Limites Normativos. Tese. Livre-Docência. Universidade de São Paulo, 2008.

BECKER, Alfredo Augusto. Teoria Geral do Direito Tributário. 2. ed. São Paulo: Saraiva, 1972.

BELSUNCE, Horácio García. El concepto de Redito em la Doctrina y en el Derecho Tributário. Buenos Aires, Depalma, 1967.

BIANCO, João Francisco. Aparência Econômica e Natureza Jurídica. In: MOSQUERA, Roberto Quiroga. LOPES, Alexsandro Broedel (coords.). Controvérsias Jurídico-Contábeis (aproximações e distanciamentos). São Paulo, Dialética, 2010. 
BIFANO, Elide Palma. O Direito Contábil: da Lei $n^{\circ}$ 11.638/07 à Lei no 11.941/09. In: ROCHA, Sergio André (cood.). Direito Tributário, Societário e a Reforma da Lei das S/A. Vol. II. São Paulo: Quartier Latin, 2010.

Contabilidade e direito: a nova relação. In: MOSQUERA, Roberto Quiroga. LOPES, Alexsandro Broedel (coords.). Controvérsias Jurídico-Contábeis (aproximações e distanciamentos). São Paulo, Dialética, 2010.

BOZZA, Fábio Piovesan. O Novo Padrão Contábil Brasileiro e os Impactos Fiscais no Registro das Despesas de Depreciação. In: Revista Dialética de Direito Tributário no 166. São Paulo: Dialética, 2009.

BRANCO, Paulo Gonet. COELHO, Inocêncio Mártires. MENDES, Gilmar Ferreira. Curso de Direito Constitucional. 5.ed. São Paulo: Saraiva, 2010.

BRITO, Edvaldo. O excesso de retirada tributável como acréscimo patrimonial. In: MARTINS, Ives Gandra da Silva (Coord.). Imposto de Renda: conceitos, princípios, comentários. 2.ed. São Paulo: Atlas, 1996.

CÂMARA, Miriam C. R., FESLBERG, Thomas Benes. Contabilização de Operações e Arrendamento Mercantil. Revista de Direito Mercantil, Industrial, Econômico e Financeiro. No $68,1987$.

CAMARGO, Renald Antônio Franco de. A Influência e Contribuição da Legislação Tributária na Contabilidade no Brasil. Dissertação. Mestrado. Pontifícia Universidade Católica de São Paulo, 1997.

CARRAZZA, Roque Antônio. Curso de Direito Constitucional Tributário. 19. ed. São Paulo: Malheiros, 2004.

Imposto sobre a Renda (perfil constitucional e temas específicos). 3a. ed. São Paulo: Malheiros, 2009.

CARVAlHO, Aurora Tomazini de. Curso de Teoria Geral do Direito: o constructivismo lógico-semântico. São Paulo: Noeses, 2009.

CARVALHO, Paulo de Barros. Direito Tributário: Fundamentos Jurídicos de Incidência. 3. ed. São Paulo: Saraiva, 2004.

Curso de Direito Tributário. 17. ed. São Paulo: Saraiva, 2005.

Direito Tributário, linguagem e método. São Paulo: Noeses, 2008.

COELHO, Cláudio Ulysses Ferreira; LINS, Luiz dos Santos. Teoria da Contabilidade. Abordagem Contextual, Histórica e Gerencial. São Paulo: Atlas, 2010.

COMPARATO, Fábio Konder. O irredentismo da "nova contabilidade" e as operações de “leasing”. Revista de Direito Mercantil, Industrial, Econômico e Financeiro. n 68. São Paulo: Revista dos Tribunais, 1987. 
CONTI, José Maurício. Princípios da Capacidade Contributiva e da Progressividade. São Paulo: Dialética, 1997.

COSTA, Alcides Jorge. Conceito de Renda Tributável. In: MARTINS, Ives Gandra da Silva (coord.). Estudos sobre o Imposto de Renda (Em memória de Henry Tilbery). São Paulo: Resenha Tributária, 1994.

COSTA JÚNIOR, Paulo José da. Direito Penal: curso completo. 7.ed. São Paulo: Saraiva, 2000.

DERZI, Misabel de Abreu Machado. Direito Tributário, direito penal e tipo. São Paulo: Editora Revista dos Tribunais, 1988.

DODGE, Joseph M. Theories of Tax Justice: Ruminations on the Benefit, Partnership, and Ability-to-pay Principles. N.Y.U. Tax Law Review.

FERNANDES, Edison Carlos. Lei Contábil e o custo dos tributos. In: FERNANDES, Edison Carlos. PEIXOTO, Marcelo Magalhães (coords.). Aspectos tributários da nova lei contábil: Lei 11.638/07. São Paulo: MP Ed., 2010.

FIUZA, Ricardo (coord.). Novo Código Civil Comentado. São Paulo: Saraiva, 2002.

FLUSSER, Vilém. Língua e Realidade. 2.ed. São Paulo: Annablume, 2004.

FREITAS, Vladimir Passos de (coord.). Código Tributário Nacional Comentado: doutrina e jurisprudência. 2.ed. São Paulo: Revista dos Tribunais, 2004.

GALHARDO, Luciana Rosanova, LOPES JÚNIOR, Jorge Ney de Figueirêdo, As Novas Normas Contábeis e a Amortização Fiscal do Ágio. In: MOSQUERA, Roberto Quiroga. LOPES, Alexsandro Broedel (coords.). Controvérsias Jurídico-Contábeis (aproximações e distanciamentos). São Paulo, Dialética, 2010.

GAMA, Evandro Costa. A reforma tributária e a autonomia financeira das entidades subnacionais. In: Federalismo Fiscal. CONTI, José Maurício (org.) Barueri: Manole, 2004.

GOMES, Orlando. Introdução ao Direito Civil. 19.ed. Rio de Janeiro: Forense, 2007.

GODOI, Marciano Seabra de. Justiça, Igualdade e Direito Tributário. São Paulo: Dialética, 1999.

GONÇALVES, José Artur Lima. Imposto sobre a Renda - Pressupostos Constitucionais. São Paulo: Malheiros, 2002.

GUASTINI, Riccardo. Distinguiendo - Estúdios de teoria y metateoría del derecho. Barcelona: Gedisa, 1999.

GUTIERREZ, Miguel Delgado. O Imposto de Renda e os Princípios da Generalidade, da Universalidade e da Progressividade. Tese. Doutorado. Universidade de São Paulo, 2009. 
GRAU, Eros Roberto. Ensaio e Discurso sobre a Interpretação/Aplicaçação do Direito. 5. ed. São Paulo: Malheiros, 2009.

HENDRIKSEN, Eldon S.; BREDA, Michael F. Van. Teoria da Contabilidade. 1. ed. 8. reimpr. Tradução de Antonio Zoratto Sanvicente. São Paulo: Atlas, 2010.

HOLMES, Kevin. The Concept of Income. A Multi-Disciplinary Analysis. The Netherlands. IBFD Publications BV, 2000.

IUDÍCIBUS, Sérgio de. Essência sobre a forma e o valor justo: duas faces da mesma moeda. In: MOSQUERA, Roberto Quiroga. LOPES, Alexsandro Broedel (coords.). Controvérsias Jurídico-Contábeis (aproximações e distanciamentos). São Paulo, Dialética, 2010.

Teoria da contabilidade. 10.ed. São Paulo: Atlas, 2010.

IUDÍCIUS, Sérgio de; GELBCKE, Ernesto Rubens; MARTINS, Eliseu. Manual de Contabilidade das Sociedades por Ações: aplicável às demais sociedades. $6^{\mathrm{a}}$ ed., ver. e atual. São Paulo: Atlas, 2003.

Manual de Contabilidade das Sociedades por Ações: aplicável às demais sociedades. Suplemento. São Paulo: Atlas, 2008.

. Manual de Contabilidade Societária. São Paulo: Atlas, 2010.

KAM, Vernon. Accounting Theory. 2a ed. New York: John Wiley and Sons, s/d.

LANG, Joachim. The Influence of Tax Principles on the Taxation of Income From Capital. In: EATLP Congress, Cologne 12-14 June 2003. IBFD, 2003.

LAPATZA, J. J. Ferreiro. Justicia Tributaria. Revista de Direito Tributário nº 46. São Paulo: Revista dos Tribunais, 1988.

Direito Tributário: teoria geral do tributo. Barueri: Manole, 2007.

LEMKE, Gisele. Imposto de Renda - os Conceitos de Renda e de Disponibilidade Econômica e Jurídica. São Paulo: Dialética, 1998.

LOPES, Alexsandro Broedel. MARTINS, Eliseu. Teoria da Contabilidade: uma nova abordagem. São Paulo, Atlas, 2005.

MACHADO, Brandão. Breve Exame Crítico do Art. 43 do CTN. In: MARTINS, Ives Gandra da Silva (coord.). Estudos sobre o Imposto de Renda (Em memória de Henry Tilbery). São Paulo: Resenha Tributária, 1994.

MARTINEZ, Antonio Lopo. A linguagem contábil no Direito Tributário. Dissertação. Mestrado. Pontifícia Universidade de São Paulo, 2002.

MARTINS, Eliseu (coord.). Avaliação de empresas: da mensuração contábil à econômica. 1. ed. 6. reimpr. São Paulo: Atlas, 2009. 
MARTINS, Eliseu. Ensaio sobre a Evolução do Uso e das Características do Valor Justo. In: MOSQUERA, Roberto Quiroga. LOPES, Alexsandro Broedel (coords.). Controvérsias Jurídico-Contábeis (aproximações e distanciamentos). São Paulo, Dialética, 2010.

MARTINS, Natanael. A Realização da Renda como Pressuposto de sua Tributação. Análise sobre a Perspectiva da Nova Contabilidade e do RTT. In: MOSQUERA, Roberto Quiroga. LOPES, Alexsandro Broedel (coords.). Controvérsias Jurídico-Contábeis (aproximações e distanciamentos). São Paulo, Dialética, 2010.

MARTINS, Ricardo Lacaz. A Tributação da Renda Imobiliária. Tese. Doutorado. Universidade de São Paulo, 2009.

MINATEL, José Antonio. Conteúdo do Conceito de Receita e Regime Jurídico para a sua Tributação. São Paulo: MP Editora, 2005.

MIRANDA, Pontes de. Tratado de Direito Privado. Tomo II. 4.ed. São Paulo: Ed. Revista dos Tribunais, 1983.

MODESTO, Carvalhosa. Comentários à Lei de Sociedades Anônimas. 3.vol. São Paulo: Saraiva, 2003.

MONTEIRO, Marco Antônio M., MUNIZ, Ian. O RTT e a Neutralidade Fiscal. In: ROCHA, Sérgio André (coord). Direito Tributário, Societário e a Reforma da Lei das S/A. Vol. II. São Paulo: Quartier Latin, 2010.

MOSQUERA, Roberto Quiroga. O Conceito Constitucional de Renda e Proventos de Qualquer Natureza. Dissertação. Mestrado. Pontifícia Universidade Católica de São Paulo, 1996.

LOPES, Alexsandro Broedel. O Direito Contábil - Fundamentos Conceituais, Aspectos da Experiência Brasileira e Implicações. In: MOSQUERA, Roberto Quiroga. LOPES, Alexsandro Broedel (coords.). Controvérsias Jurídico-Contábeis (aproximações e distanciamentos). São Paulo, Dialética, 2010.

MOUSSALLEM, Tárek Moyses, Fontes no direito tributário. 2.ed. São Paulo: Noeses, 2006.

NICACIO, Carlos N.. QUERQUILLI, Alexandre G. Mudanças nas regras contábeis, experiências internacionais e a relativa neutralidade do regime tributário de transição. In: FERNANDES, Edison Carlos. PEIXOTO, Marcelo Magalhães (coords.). Aspectos tributários da nova lei contábil: Lei 11.638/07. São Paulo: MP Ed., 2010.

NOGUEIRA, Ruy Barbosa. Curso de Direito Tributário. 3. ed. São Paulo: Saraiva, 1971.

OLIVEIRA, Erival da Silva. Direito Constitucional. $3^{\text {a }}$ ed. São Paulo: DPJ ed., 2004.

OLIVEIRA, Ricardo Mariz de. Fundamentos do Imposto de Renda. São Paulo: Quartier Latin, 2008. 
A Tributação da renda e sua relação com os princípios contábeis geralmente aceitos. In: MOSQUERA, Roberto Quiroga. LOPES, Alexsandro Broedel (coords.). Controvérsias Jurídico-Contábeis (aproximações e distanciamentos). São Paulo, Dialética, 2010.

PASQUALIN FILHO, Roberto. Comentários à Lei das sociedades por ações: Lei 6.404/76. coordenação: Geraldo de Camargo Vidigal e Ives Gandra da Silva Martins. São Paulo: Ed. Resenha Universitária: Instituto dos Advogados de São Paulo, 1978.

PASSOS, Carlos Roberto Martins. NOGAMI, Otto. Princípios de Economia. 5.ed. São Paulo: Thomsom Leaning, 2006.

PEREIRA, Caio Mário da Silva. Instituições de Direito Civil. 20.ed. vol. I. Rio de Janeiro: Forense, 2004.

PEDREIRA, José Luiz Bulhões. Imposto sobre a Renda - Pessoas Jurídicas. Vol. I. Rio de Janeiro: Justec, 1979.

PÊGAS, Paulo Henrique. Manual de Contabilidade Tributária: teoria e prática. Rio de Janeiro: Freitas Bastos, 2004.

PIZOLIO, Reinaldo. Competência Tributária e Conceitos Constitucionais. São Paulo: Quartier Latin, 2006.

POLIZELLI, Victor Borges. Progressividade: Distribuição de Renda e Indução. In: Revista Direito Tributário Atual no 21. BONILHA, Paulo Celso Bergostrom; COSTA, Alcides Jorge; SCHOUERI, Luís Eduardo (coords). São Paulo: Dialética, 2007.

. O Princípio da Realização da Renda e sua Aplicação no Imposto de Renda das Pessoas Jurídicas. Dissertação. Mestrado. Universidade de São Paulo, 2009.

Balanço Comercial e Balanço Fiscal: Relações entre o Direito Contábil e o Direito Tributário e o Modelo Adotado pelo Brasil. in: Direito Tributário Atual no 24 . Coords. BONILHA, Paulo Celso Bergstrom, COSTA, Alcides Jorge, SCHOUERI, Luís Eduardo, ZILVETTI, Fernando Aurélio. São Paulo: Dialética, 2010.

QUEIROZ, Luís César Souza de. Imposto sobre a renda: requisitos para uma tributação constitucional. Rio de Janeiro: Forense, 2003.

RÁO, Vicente. O Direito e a Vida dos Direitos. Vol. I, Tomo II. 2.ed. São Paulo: Ed. Resenha Universitária, 1976.

REALE, Miguel. Lições Preliminares de Direito. 24.ed. São Paulo: Saraiva, 1998.

RENCK, Renato Romeu. Imposto de renda da pessoa jurídica: critérios constitucionais de apuração da base de cálculo: uma proposta de interpretação sistemática do Direito. Porto Alegre: Livraria do Advogado, 2001.

RIBEIRO, Ricardo Lodi. TAVARES, Adriana Clemente de Souza. O planejamento fiscal pela metodologia de ajustes a valor presente - AVP introduzida pela Lei $n^{o}$ 11.638/2007. 
In: ROCHA, Sergio André (cood.). Direito Tributário, Societário e a Reforma da Lei das S/A. São Paulo: Quartier Latin, 2008.

SCHMIDT, Paulo. História do Pensamento Contábil, Porto Alegre: Bookman, 2000.

SCHOUERI, Luís Eduardo. Discriminação de Competências e Competência Residual. In: Direito Tributário: Estudos em Homenagem a Brandão Machado. São Paulo: Dialética, 1998.

Forense, 2005.

Normas tributárias indutoras e intervenção econômica. Rio de Janeiro:

. O mito do Lucro Real na Passagem da Disponibilidade Jurídica para a Disponibilidade Econômica. In: MOSQUERA, Roberto Quiroga. LOPES, Alexsandro Broedel (coords.). Controvérsias Jurídico-Contábeis (aproximações e distanciamentos). São Paulo, Dialética, 2010.

TERSI, Vinicius Feliciano. Algumas ponderações a respeito do regime tributário de transição. In: FERNANDES, Edison Carlos. PEIXOTO, Marcelo Magalhães (coords.). Aspectos tributários da nova lei contábil: Lei 11.638/07. São Paulo: MP Ed., 2010 .

Juros sobre o Capital Próprio: Natureza Jurídica e Forma de Apuração diante da 'Nova Contabilidade,’”. In: MOSQUERA, Roberto Quiroga. LOPES, Alexsandro Broedel (coords.). Controvérsias Jurídico-Contábeis (aproximações e distanciamentos). Vol. III. São Paulo, Dialética, 2012.

SILVA, José Afonso da. Curso de Direito Constitucional Positivo. São Paulo: Malheiros, 2001.

SILVEIRA, Paulo Antônio Caliendo Velloso da. Direito Tributário e análise econômica do Direito: uma visão crítica. Rio de Janeiro: Elsevier, 2009.

SIQUETTO, Paulo Roberto. Os projetos de reforma constitucional tributária e o federalismo fiscal brasileiro. In: Federalismo Fiscal. CONTI, José Maurício (org.) Barueri: Manole, 2004.

SMITH, Adam. Riqueza das Nações: uma investigação sobre a natureza e as causas da riqueza das nações; tradução Getulio Schanoski Jr. São Paulo: Madras, 2009.

TIPKE, Klaus, LANG, Joaquim; (colaboradores) Romam Seer ... (et. al.) Direito Tributário (Steuerrecht). Vol. I. Tradução da $18^{a}$ edição alemã, totalmente refeita, de Luiz Dória Furquim. Porto Alegre: Sergio Antonio Fabris Ed., 2008.

TORRES, Ricardo Lobo. Tratado de Direito Constitucional Financeiro e Tributário. Valores e Princípios Constitucionais Tributários. Vol. II. Rio de Janeiro, Editora Renovar: 2005. 
Normas de Interpretação e Integração do Direito Tributário. 4.ed. Rio de

Janeiro, Editora Renovar: 2006.

UCKMAR, Victor. Princípios Comuns de Direito Constitucional Tributário. Tradução de Marco Aurélio Greco. $2^{a}$ edição. São Paulo: Editora Malheiros, 1999.

UTUMI, Ana Cláudia Akie. O ágio nas Operações de Fusões e Aquisições em Face das Novas Regras Contábeis. In: MOSQUERA, Roberto Quiroga. LOPES, Alexsandro Broedel (coords.). Controvérsias Jurídico-Contábeis (aproximações e distanciamentos). São Paulo, Dialética, 2010.

VELLOSO, Andrei Pitten. Conceitos e competências tributárias. São Paulo: Dialética, 2005 .

WALD, Arnoldo. Direito das Obrigações. Teoria Geral das Obrigações e Contratos Civis e Comerciais. 15. ed. São Paulo: Malheiros, 2001.

XAVIER, Alberto. Tipicidade da Tributação, Simulação e Norma Antielisiva. São Paulo: Editora Dialética, 2001.

Direito Tributário Internacional do Brasil. $7^{\mathrm{a}}$ ed. Rio de Janeiro: Forense, 2010.

ZILVETI, Fernando Aurélio. O Princípio da Realização da Renda. In: Luís Eduardo Schoueri (coord.). Direito Tributário - Homenagem a Alcides Jorge Costa. vol. I. São Paulo: Quartier Latin, 2003. Obrigação Tributária - Fato Gerador e Tipo. São Paulo: Quartier Latin, 2009. 